\title{
DAS PRÁTICAS E SABERES EM SAÚDE MENTAL $O$ cotidiano do trabalho em hospital dia infantil, no Município de São Paulo
}

\section{PATRÍCIA MARTINS MONTANARI}

Tese de Doutorado apresentada ao Departamento de Saúde Materno-Infantil da Faculdade de Saúde Pública da Universidade de São Paulo para a obtenção do título de Doutor em Saúde Pública.

Área de concentração: Saúde Materno-infantil

Orientador: Prof. Assoc. Néia Schor

São Paulo

2003

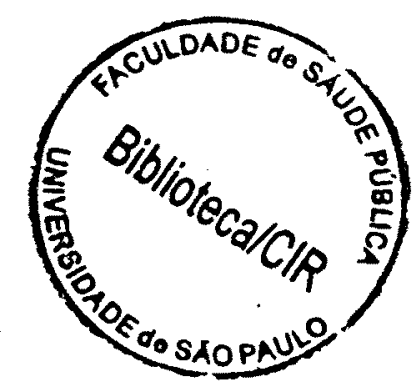


Autorizo, exclusivamente para fins acadêmicos e científicos, a reprodução total ou parcial desta tese, por processos fotocopiadores.

Assinatura:

Data: 
Dedico esta tese a todos os profissionais de saúde pública, que fazem de sua prática profissional uma profissão de fé;

aos profissionais da saúde mental, que têm sido 'os sentidos' através dos quais muitas pessoas tidas como incapazes se comunicam e se fazem respeitar, para quem o sofrimento humano é mais que objeto de intervençâo;

à minha mãe, D. Olga, um exemplo de profissional da saúde;

à Keiko Ogura Buralli, por tudo isso! Que falta você nos faz...

Registro, ainda, minha homenagem à memória de Lygia Assumpção Amaral, que fez de sua prática intelectual um campo de batalha contra o preconceito. 


\title{
Agradecimentos
}

\author{
"Não fosse isso \\ e Era menos \\ näo Fosse tanto \\ e Era quase"
}

Paulo Leminski

Impressionante como uma tese (ou mesmo um discurso de paraninfo) pode nos levar a tantos lugares e desencadear tantas emoções, sobretudo quando o tema e a abordagem escolhida te fazem percorrer diversos lugares e mundos, pessoas e emoções.

Por conta disso, faz-se necessário e oportuno agradecer a algumas pessoas que foram fundamentais nessa estrada:

Agradeço ao Conselho Nacional de Pesquisa e Desenvolvimento, o CNPq, pelo apoio concedido nesses anos de estudo e pesquisa.

Aos profissionais de saúde mental da rede pública, "sujeitos-objeto" do presente trabalho, com quem convivi nos dois anos de pesquisas de campo, sempre tão disponiveis, interessados, engajados e amorosos: o meu muito obrigada!

Aos colegas, funcionários e professores do Departamento de Saúde MaternoInfantil que sempre foram um porto seguro para as minhas aflições intelectuais e pessoais. Destaco alguns colaboradores mais sistemáticos: à Prof". Néia Schor, minha querida orientadora, que sempre foi continente para com minhas decisões, colocando limites e me chamando à responsabilidade, agradeço do fundo do meu coração a confiança; Ideraldo Luiz Beltrame, Kimy Otsuka Stasevskas, Kátia Cibelle Machado Pirotta, Maria Aparecida Miranda de Paula Machado, Ana Paula França: meus amigos queridos de tanto tempo, gratidão eterna por compartilhar com vocês a "aventura do conhecimento" e outras aventuras... valeu!!!: 
aos professores Cornélio Rosemburg, Fumika Peres, Keiko Ogura Buralli (in memorian), Augusta Thereza de Alvarenga, Ana Cristina d'Andretta Tanaka, pela generosidade e compromisso com a formação dos estudiosos e profissionais da saúde pública, muito obrigada pela oportunidade de "beber nesta fonte"; ao Leandro, por me chamar a atenção para os prazos e datas de entrega da tese, pela sua eficiência no manejo das questões burocráticas, o meu muito obrigada; ao Silvio, querido amigo, que muito me ajudou na pesquisa de campo, viabilizando minhas saidas, o meu muitíssimo obrigada!

Agradeço à Prof. Ana Pitta, pelo carinho e generosidade no exame de qualificação: rendo-lhe minhas homenagens por tudo o que representa para o campo da saúde mental. Agradeço, também, às Professoras Lilia Blima Schraiber e Marina Peduzzi, com quem tive o privilégio de trabalhar e aprender, que me apresentaram à rede pública de saúde. Foi tão importante para mim que inspirou esta tese. À professora Fabiola Zioni, que prontamente aceitou integrar a banca examinadora, cujas correções e sugestões pontuais contribuiram em muito com a versão final da tese: muito obrigada!

Aos meus queridos pais, Dona Olga e Seu Antônio, pelo orgulho que sentem de mim e por tudo que investiram na minha formação, especialmente o amor que me dedicam, o meu muitissimo obrigada! Acredito que os valores éticos e morais que me ensinaram permearam este trabalho em diversos momentos e aspectos.

À minha avó, Dona Adelaide Fagá Montanari, por tanto amor e colo que me dedicou a vida inteira. Talvez nunca possa retribuir, mas registro aqui meu reconhecimento e afeto. Ao meu tio paterno, Eduardo Femando Montagnari, pela capacidade e prazer de refletir com os quais muito me identifico. Sempre quis ser como você. Agora jả sou como eu mesma, muito de você. Obrigada! Ao "anjo da guarda" dos dois, Marco Aurélio Raimundo de Macedo, que cuida deles com tanto desvelo e de vez em quando atravessa o corredor para fumar um cigarro lá em casa, obrigada. 
Os "velhos" amigos são essenciais na minha vida e por mais que atualmente eu não os veja com "aquela" freqüência, por motivos que extrapolam os limites destes agradecimentos, devo dizer que lembro e penso muito em vocês, fiéis escudeiros, para quem a palavra é muito mais que ferramenta de trabalho: Ludmila Antunes, Paulo Tadeu da Silva, Mirela Berger, Silvana Maria de Souza, Femanda Estima, obrigada por tudo, amo vocês!!!

Quanto à novas amizades, confesso que fiquei menos disposta, mas ainda tenho a felicidade de conhecer pessoas da melhor qualidade. A JUBA, Juliana Lóra de Sá, ex-aluna e fisioterapêuta, hoje companheira de todas as horas, seja com as caronas ou ao emprestar-me o computador; providenciando comidinhas e acompanhando minha mãe ao médico para que eu pudesse trabalhar na tese: que bom que você apareceu! Faz a vida ter mais 'sentido'!!! 


\section{Índice}

Resumo $i$

Summary $\quad$ ii

Apresentação

$\begin{array}{lr}\text { 1. Introdução } & 8\end{array}$

1.1 A institucionalização das práticas de saúde e a emergência do trabalhador coletivo 8

1.2 As politicas de saúde na transição democrática 23

1.3 Novos panoramas da assistência à saúde mental en São Paulo: os anos 80 e $90 \quad$ it

1.f Perspectivas de saúde (mental) no mundo: os anos $2000+3$

1.5 Objetivos

2. Metodologia 56

2.1 Procedimentos metodológicos

2.1.1 Levantamento quantitativo: a primeira etapa da pesquisa de campo

2.1.2 Levantamento qualitativo: a segunda etapa da pesquisa de campo

2.2 Referenciais Teóricos

3. Caracterização dos trabalhadores de saúde mental: fazendo uma primeira costura

3.1 Caracterização geral dos trabalhadores de saúde mental $8+$

3.2 Perfil dos trabalhadores de nivel universitário

3.2.1 Trabalhadores universitários e situação profissional 93 
4.2 Por 'uma experiência democrática brasileira': caracterização do Hospital Dia Infantil em Saúde Mental da Moóca e de seus profissionais

4.3 Dos saberes às práticas: formação e trajetória profissional na 'construção do olhar'

4.3.1 Aspectos da constituição do serviço social como prática de saúde: 'em busca de um lugar ao sol'

4.3.2 Do alienismo ao organicismo: 'quem tem medo da nova psiquiatria?'

4.3.3 'O que quer, o que pode essa lingua?': a emergência das práticas fonoaudiológicas

4.3.t 'É preciso tirar o avental da cabeça': os caminhos da enfermagem

4.3.5 'Freud explica?!': as mediações da psicologia e da terapia ocupacional

Anexos

Glossário 


\section{RESUMO}

Montanari PM. Das práticas e saberes em saúde mental: o cotidiano do trabalho em hospital dia infantil, no Município de São Paulo. São Paulo; 2003. [Tese de Doutoramento - Faculdade de Saúde Pública da Universidade de São Paulo].

Proponho uma reflexão acerca do trabalho em saúde mental, considerando a organização dos serviços públicos substitutivos, no momento de transição do processo de municipalização da saúde, em sua modalidade ambulatorial e hospital dia. Pretendeu-se, portanto, identificar e compreender, para o Município de São Paulo, como os serviços de saúde mental do setor público organizam sua força de trabalho, como estão os recursos humanos efetivamente incorporados e como estes se articulam e configuram a prestaçào da assistência. Para tanto, num primeiro momento, foram mapeados os profissionais de saúde mental, segundo a categoria ocupacional a que pertencem e caracterizado o perfil desses profissionais, segundo as seguintes variáveis: sexo, idade, jornada de trabalho, vinculo empregatício, tempo de trabalho na unidade no momento da entrevista, tempo de trabalho no serviço público. Foi montado um banco de dados em software compativel com as variáveis consideradas (EPI INFO) para que tais informaçòes pudessem ser analisadas estatisticamente e revelassem as tendências que favorecessem a reflexão sobre a conformação das equipes e particularidades do atendimento em saúde mental. Num segundo momento, foram realizadas entrevistas gravadas, em profundidade, com os profissionais do HDI da Moóca, serviço identificado na primeira fase como 'referência', para serem abordados os aspectos das representaçōes e percepções que estes profissionais têm acerca de sua prática profissional, o que favoreceu o entendimento dos mecanismos de articulação entre o saber técnico e o saber operante utilizados, que constituem a atenção em saúde mental. Verificou-se que o trabalho nesta rede de serviços é eminentemente feminino, sobretudo em áreas como o serviço social e enfermagem; que embora tratem-se de serviços intensivos, a jornada de trabalho média dos profissionais gira em tomo de 30 horas semanais, sugerindo que o tipo de intervenção realizada é também muito intenso para quem a oferece; a distribuição dos profissionais por categoria ocupacional não variou significativamente entre as duas modalidades consideradas, assim como a proporção do número de mulheres e homens em relação às categorias psicólogo e médico, também nas duas modalidades assistenciais. Quanto à especializaçào dos profissionais, tem-se um número grande de menções à psicanálise, psicologia clinica e saúde pública. As descrições e avaliações acerca do trabalho desenvolvido pelo HDI da Moóca, segundo sua própria equipe, revelaram a especificidade do conjunto das práticas que integram em relação aos demais serviços de saúde. A despeito de sua composição objetiva corresponder à tendência ocupacional identificada na primeira fase, e nesse sentido ser representativa, o HDI preserva algumas particularidades quanto às concepções gerais acerca da saúde e do trabalho em serviços públicos, revelando-se aí um papel político, de responsabilidade social: referem-se como cquipe em uníssono, e de fato o são, e tal percepção é amplificada em função dos laços pessoais que mantêm. De todo modo, seu trabalho, articulado aos saberes, principalmente ao da psicologia com destaque para a psicanálise, e fortemente impregnados pela prática,tenta romper com a divisão vertical do trabalho ao mesmo tempo em que expressa e reivindica o 'status' de equipe transdisciplinar e/ou multiprofissional.

Descritores: Saude Mental; Serviços; Trabalho em Saúde; Equipe de Saude: Interdisciplinariedade. 


\section{SUMMARY}

Montanari PM. Das práticas e saberes em saúde mental: o cotidiano do trabalho em hospital dia infantil, no Municipio de São Paulo [On the practices and knowledge in mental health: the work quotidian in children day hospital in São Paulo City]. São Paulo (BR); 2003. [Tese de Doutorado - Faculdade de Saúde Pública da Universidade de São Paulo]

A reflection on mental health work is proposed considering the organization of substitutive public services, currently undergoing health municipalization transition process, in their out patient clinic and day hospital modes. The aim was the identification and understanding of how the public sector mental health services organize their workforce, how the human resources are effectively incorporated and how they articulate and configure the attendance rendering. For that purpose, in the first phase, the mental health professionals were mapped by occupational category and their profile was characterized under the variables sex, age, work load, job attachment, length of work in the unit at the interview and work length in the public service. A database was designed with software compatible with the variables (EPI INFO) for the statistical analysis of the information. Such analysis revealed the trends that favored the reflection on the team conformation and specificity of mental health attendance. In the second phase audio recorded in-depth interviews were carried out with professionals of the Moóca Children Day Hospital (CDH), a service identified in the first phase as 'reference'. The interviews probed the representations and perceptions these professionals hold on their professional practice. That availed the understanding of the articulation mechanisms between the technical and operative knowledge used which constitute mental health attention.

It was observed that in this mental health service network the work is eminently feminine especially in the social service and nursing areas. It was also noted that although the services are intensive the average workload is around 30 hours/week, which suggests the high intensity of that kind of intervention for the professionals There was no significant variation in the distribution of professionals by occupational category and the proportion women/men in relation to psychologist and medical doctor categories in both attendance modes. Concerning specialization, there was ample reference to psychoanalysis, clinical psychology and public health.

The description and evaluation of the work developed by the Mooca HDI, according to its own team, revealed the specificity of the set of integrated practices in relation to the other health services. Despite its objective composition correspondence to the occupational trend identified in the first phase, and in this sense being significative, the $\mathrm{CDH}$ preserves a few particularities in terms of general conceptions on health and work in public service thus disclosing a political role of social responsibility. The professionals in unison refer to it as team, which they actually are, although such perception/concept emerges renewed. Anyway, their work, besides to the knowledge, mainly the psychological one, strongly impregnate by the pratices, trying to break with the work's vertical division in the same time that express the status of interdisciplinary and/or transdisciplinary team.

Descriptors: Mental health; Services; Work in Health; Health Team; Interdisciplinarity. 


\section{Apresentação}

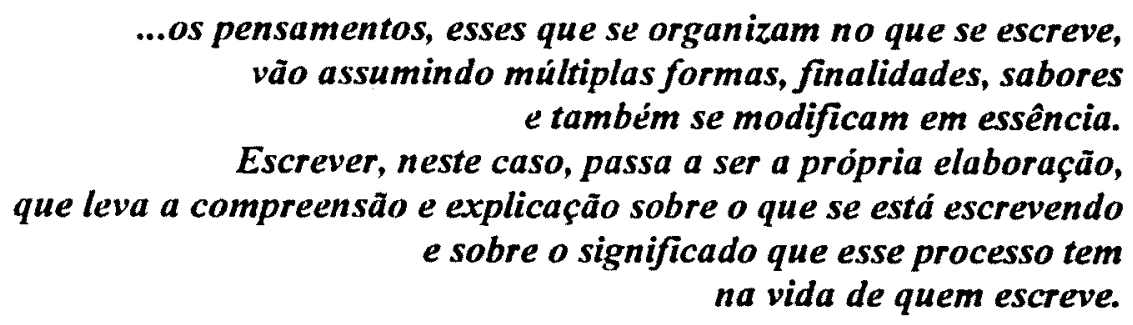

PMM

O meu "namoro" com o campo da saúde coletiva já tem pouco mais de uma década: começou no final de 1991, quando cursava o $3^{\circ}$ ano de Ciências Sociais e o estágio de dois anos na Secretaria do Bem-Estar Social da Prefeitura Municipal de São Paulo chegara ao fim. Conjecturando acerca das possibilidades de trabalho para uma cientista social em formação, eis que me deparo com Valéria, colega de curso e entusiasmada coordenadora de campo de uma pesquisa, desenvolvida pela Faculdade de Saúde Pública da USP, intitulada "Morbidade e mortalidade maternas. qualidade da assistência e estrutura social: estudo da Região Sul do Municipio de São Paulo" (SIQUEIRA et. al. 1993). Por seu intermédio, conheci a Faculdade, o projeto de pesquisa, passei a integrar a equipe de pesquisadoras e fui apresentada à Prof. Néia Schor, bem como aos demais professores do Departamento de Saúde MaternoInfantil, então pesquisadores responsáveis pelo projeto.

Inicialmente, fui incorporada pelo Departamento em duas frentes de trabalho: primeiro, como pesquisadora de campo, realizando entrevistas domiciliares para a 
segunda fase da coleta de dados da referida pesquisa; posteriormente, como bolsista de iniciação científica já sob orientação da Prof . Néia, quando tomei contato com todo o processo de tratamento e análise de dados quantitativos.

A certa altura, já familiarizada com parte do universo prático (ou empírico) da pesquisa na área da saúde, questões sobre as quais versavam a pesquisa, a saber: saúde reprodutiva, mortalidade e morbidade maternas, organização familiar e de serviços de saủde e suas implicações sociológicas e antropológicas, tais como a desigualdade social que expressam, permitiu-me perceber quão fértil era esse campo, agregador de conhecimentos de diversas áreas, interdisciplinar “pela própria natureza".

Tamanha afinidade me levou ao programa de pós-graduação, sob orientação da Prof. Néia. E perseguindo sua linha de pesquisa (ou procurando o fio da meada), a problemática da saúde do adolescente se configurou para mim como a mais contundente e pude incorporar a esta outras discussões que já vinha fazendo na graduação, também por ocasião da iniciação científica, sobre representações sociais da deficiência entre alunos da USP (BERGER et. al. 1992). Nas entrevistas que realizava, foram aparecendo algumas imagens sobre os profissionais de saúde e o que me era confidenciado apontava aspectos tão negativos que fiquei intrigada.

Ao conjugar as temáticas adolescência e deficiência no âmbito da saúde pública, interessava-me resgatar antigas preocupações: quem é esse adolescente, como se sente, age e pensa? Que relações estabelece com seu corpo, sua sexualidade? Seria igual aos demais, já tão investigados pela saúde pública? Principalmente, era 
necessário entender como lidava com a sua condição de deficiente. Como "eterno paciente", como percebia e se relacionava com os profissionais e instituições de saúde? (MONTANARI 1998,1999).

Ainda na busca por essas respostas, desencadeadas por novas preocupações, por exemplo: como estes (e outros) profissionais vêem e percebem seus pacientes e suas necessidades, enveredei-me por dois caminhos ricos em possibilidades de interlocução e debate: pesquisar em serviços e lecionar em cursos na área da saúde. No primeiro caso, a oportunidade de participar de uma pesquisa financiada pela OPAS e coordenada pela Prof. Assoc. Lilia Blima Schraiber, do Departamento de Medicina Preventiva da Faculdade de Medicina da USP, sobre Recursos Humanos em Saúde (SCHRAIBER e PEDUZZI 1999); no segundo, o inicio de minha atividade na docência superior no curso de fisioterapia da Universidade Santo Amaro.

O denominador comum aqui foi o aspecto profissional: visitando alguns serviços, em diferentes modalidades assistenciais e tipos institucionais, eu pude me aproximar da prestação da assistência à saúde no Município de São Paulo e, portanto, da organização político-administrativa de que é expressão, e do exercicio profissional de alguns trabalhadores que entrevistei e cujo trabalho pude acompanhar. Quanto as aulas de metodologia científica para os primeiro-anistas de fisioterapia, passávamos da discussão acerca da construção desse campo do conhecimento a aspectos éticos da profissão e mercado de trabalho. Àquelas questões anteriores somou-se outra: que profissional de saúde queremos e precisamos? Participar da formação desses profissionais abriu a minha perspectiva intelectual, de vida, o meu olhar, acho que 
nesse momento já começava a se delinear, para mim, uma nova problemática de investigação...

Ao ingressar no doutorado, ainda no Departamento de Saúde MaternoInfantil, fui acometida por uma crise depressiva (ou existencial?) que me imobilizou e se arrastou por algum tempo, quando passei a receber acompanhamento profissional. A partir dai, iniciando o trabalho de pesquisa bibliográfica, minha atenção se voltou para questões relativas à saúde mental na rede pública de saúde, temática tão próxima a mim naquele momento (e sempre). Esta escolha implicou em um esforço maior de minha parte e também de minha orientadora, pois tivemos que nos dedicar a novas leituras, conhecer novos conceitos e terminologias, e também significou encontrar novamente um fio condutor que articulasse saúde mental a saúde materno-infantil e estas aos referenciais teóricos com os quais tinhamos familiaridade.

Considerando minha formação e minha trajetória na saúde coletiva, uma alternativa bastante atraente e que pareceu atender às exigências anteriores foi a de abordar a organização dos serviços e o processo de trabalho em saúde mental, destacando-se nesta abordagem a relação que se estabelece entre saberes, conteúdos técnicos e a prática da assistência.

Neste sentido, as discussões a respeito da assistência em Saúde Mental, no Brasil, têm sido marcadas pela dificuldade de delimitação de seu campo de prática e atuação. Desde sua emergência, no final do século XVIII, as dificuldades e contradições das práticas da psiquiatria se expressam no cotidiano do próprio trabalho - procedimentos e condutas - e na constituição de um corpo teórico que oriente tais 
condutas. além da desarticulação de tais aspectos à saúde como um todo e às ações sociais mais amplas (NUNES FILHO et. al. 1996).

Como mostra FOUCAULT (1999), os conhecimentos que sustentam e legitimam cientificamente as práticas em saúde mental, por sua vez, estão associados, desde o reconhecimento de sua necessidade e possibilidades de sua concretização, aos problemas da vida em sociedade, por exemplo, como enfrentar e tratar a loucura e o loucọ? Qual a natureza das "perturbações fisico-morais" que acometem o ser humano? Um fato concreto é que as pessoas nestas condições ainda hoje são objeto de discriminação e preconceito. Segundo VELHO (1981), o grande paradoxo da sociedade modema é gerar a diferenciação e somente conviver com ela por meio de mecanismos discriminatórios. A coerção normalizadora, a fabricação initerrupta de desviantes, entre outras práticas, são resultado dessa realidade. A questão da "loucura" e de como lidar com ela, embora muito anterior ao surgimento das sociedades modernas, se enquadra perfeitamente nesta dificuldade de assimilação e integração do diferente.

Observam-se, assim, diversas tentativas de resposta social ou de integração desse diferente (dessa diferença) e o seu desdobramento levou a uma flexibilização (quase condecendente) da percepção social sobre o sofrimento psíquico e sobre as práticas sociais para com ele.

Do ponto de vista das intervenções de saúde, a reformulação desse objeto de conhecimento(s) engendrou a conseqüente necessidade de reformulação dos objetivos das intervenções. As proposições higiênicas, em principio, cristalizaram os aspectos 
coletivos da prática psiquiátrica: no caso de certas expressões da singularidade da vida do sujeito serem julgadas desviantes, poder-se-iam retraduzi-las em termos de anormalidade ou doença, de ordem fisico-orgânica ou moral e, assim, submetê-las a técnicas para sua reversão. Ao mesmo tempo, a formulação de proposições gerais, derivadas da problematização daquela singularidade, atualizava e transpunha para a vida coletiva os parâmetros de apreensão, enunciação e solução desses problemas. As proposições higiênicas, entretanto, não chegaram a configurar mecanismos institucionais de intervenção direta sobre a população (LIMA 1927; SANTOS 1931; YAHN 1957; MIELNIK 1976).

Do ponto de vista da construção do conhecimento, os enunciados técnicos derivados desse processo tenderam à autonomização e à polarização: de um lado, o debate teórico e de outro, a intervenção na sociedade, cuja conseqüência foi o isolamento desses dois domínios e o predominio das "questões teóricas" em relação aos objetivos e à organização do sistema assistencial.

A nova psiquiatria, expressão datada, própria do campo psiquiátrico (BIRMAN e COSTA 1976), a despeito de representar uma visão positiva ou negativa e sugerir certas imprecisões, trouxe implicitamente a necessidade de fazer esta intervenção em nome da prevenção e da recuperação, tanto para a população "normal" quanto para a doente. Essa passagem da Psiquiatria à Saúde Mental reflete uma ampliação tanto dos instrumentos quanto dos objetos de intervenção e apontam o reconhecimento da saúde mental como a própria saúde. 
Segundo PITTA HOIESEL (1984) e PEREIRA URQUIZA (1991), as necessidades sociais de reformular conceitos e rearticular a prática psiquiátrica, colocadas ao Estado, no caso de São Paulo, por exemplo, puderam, provisoriamente, ser definidas em termos da natureza social de suas práticas assistenciais, direcionadas ao louco e à loucura, práticas essas inscritas no âmbito das ações estatais, comportando ações intervencionistas cujo objetivo era tratar, prevenir e apoiar a inclusão desses individuos na vida social. Tudo isso por meio de instrumentos técnicos da psiquiatria psicanálise e psicologia, saberes estes articulados aos aportes teóricos das ciências sociais.

Portanto, a necessidade de oferecer assistência a uma população que sofre com distúrbios de natureza emocional e, por outro lado, a necessidade não menos imperiosa de manter um controle e vigilância critica sobre as articulações sociais e intelectuais dessa prática, exige a assunção de uma perspectiva que nos leve ao conhecimento da determinação das diversas instâncias técnicas que compõem esse conjunto complexo de práticas, modos de organização, saberes e detalhes dos seus desdobramentos na produção concreta dos serviços. 


\section{1 \\ Introdução}

Sir William concedia três quartos de hora a cada um dos seus pacientes: e nessa ciência exigente que lida com aquilo de que nada se sabe. em suma - o sistema nervoso, o cérebro humano se um médico perde o senso da medida, então está fracassado como médico. Saúde é o que se deve ter; e saúde é medida: de modo que. quando um homem nos entra no consultório e diz que $\dot{e}$ Cristo (uma ilusão comum) e que tem uma mensagem. como a maioria deles. e ameaça, como geralmente fazem. com o suicidio. tem-se de invocar a medida; prescrever repouso na cama: repouso na solidão; silêncio e repouso; repouso sem amigos: sem livros: sem mensagens; seis meses de repouso; até que um homem que nos chega com cinqüenta quilos saia pesando oitenta.

(...) Com a sua adoração pela medida, Sir William não só prosperava pessoalmente como fazia prosperar a Inglaterra. isolando-lhe os lunáticos. proibindo-lhes procriarem. incriminando o desespero. impedindo os incapazes de propagarem as suas idéias até que estes também compartilhassem do seu senso da medida - o seu. se eram homens (...), de modo que não apenas os colegas o respeitavam. e temiam-no os subordinados, mas os amigos e a parentela de seus pacientes lhe dedicavam a mais viva gratidão. por insistir em que aqueles proféticos Cristos e Cristesas. que anunciavam ofim do mundo. ou o advento de Deus. tomassem leite na cama. como Sir William prescrevia; Sir William. com os seus trinta anos de experiência desses casos. o seu infalivel instinto: isto é loucura. isto é senso; o seu senso da medida.

Virginia Woolf, Mrs. Dalloway 
Refletir acerca da organização do trabalho em saúde mental, na atualidade, no Município de São Paulo, implica pensar sobre o processo de especialização do trabalho em saúde, caracteristico dos tempos contemporâneos, fortemente marcado pela desarticulação das diferentes ações envolvidas nesse processo e ao mesmo tempo pela necessidade de recomposição das mesmas. Implica, ainda, relacionar tais aspectos às políticas nacionais de saúde, sobretudo ao conjunto de novas diretrizes que se constituem com a abertura democrática, a partir dos anos 80 , localizando nestas as novas orientações da política de saúde mental que se anunciam nesse periodo, motivadas, em parte, pela tendência mundial de reorganização da assistência psiquiátrica, que embasam, ainda hoje, a Reforma Psiquiátrica brasileira e o atual modelo de atenção em saúde mental.

\subsection{A institucionalização das práticas de saúde e a emergência do trabalhador coletivo}

O processo atual de reestruturação produtiva pelo qual se organiza o mundo do trabalho, tanto no âmbito internacional quanto nacional, concentrou e ainda concentra a atenção de boa parte dos estudiosos da Sociologia do Trabalho ${ }^{1}$, ainda que hoje vivamos sob o refluxo desse processo, posto que maior parte das grandes empresas, seja de capital estrangeiro, misto ou nacional já se encontrem, em alguma medida, reestruturadas.

\footnotetext{
1 Os estudos brasileiros sobre reestruturação produtiva são, em geral, sobre empresas, setores ou cadeias determinadas, e apesar de elucidarem determinados processos particulares, não oferecem uma visão de conjunto acerca das características do processo de reestruturação brasileira. Sobre este tema, destacam-se autores como CARVALHO (1990); SILVA (1991); HIRATA (1993); BRESCIANI (1997); CARLEIAL e VALLE (1997); LEITE (1997); LEITE EM (1997); COMIN (1998) citados por SOUZA (2002).
} 
Isto não significa, entretanto, afirmar que tal processo tenha chegado a seu termo, tendo em vista que um dos aspectos da atual reestruturação produtiva é exatamente a constante busca e implementação de inovações, seja no processo mesmo da produção ou do que se produz. Inovar, nesse sentido, não corresponde a uma ação com início e término determinados, embora seja possível identificar momentos de maior e de menor avanço, mas sim uma atualização constante que se coloca ao longo do tempo (SOUZA 2002).

No caso brasileiro, esse movimento pode ser observado desde a passagem do século XIX para o século XX, com a introdução dos princípios da administração cientifica e seus métodos de controle do trabalho, as idéias de Taylor até o advento do fordismo, contra o qual se debate a atual reestruturação produtiva, cujos desdobramentos variam conforme se impõem novos patamares de exigência em termos de concorrência, competitividade e qualidade (COMIN 1994).

O conceito moderno de reestruturação produtiva contém uma sucessão de estados e mudanças na área industrial, o que justifica a idéia de processo que o acompanha, em que se interpenetram questões políticas, sociais, tecnológicas e econômicas no âmbito nacional brasileiro como reflexo do cenário mundial. De um lado, relaciona-se à chamada globalização e à competição intercapitalista; de outro, às novas formas de gestão e organização da produção e do trabalho, a partir da introdução de inovações técnico-organizacionais e tributárias, oriundas, em grande parte, da crise do fordismo e da consolidação de um novo momento da acumulação capitalista: a produção flexível (SENNETT 1999; ABREU 2000). 
No que se refere ao processo de especialização em saúde - consoante ao processo de especialização do trabalho de forma geral como reflexo das sucessivas reestruturações produtivas -, este inicia-se em meados do século XIX e se intensifica ao longo do século XX, quando surgem novos trabalhadores, tais como: médicos sanitaristas, educadores sanitários, nutricionistas, enfermeiros de saude pública, fonoaudiólogos, terapeutas ocupacionais; e, também, quando mudanças radicais nas práticas de antigos agentes são percebidas, a saber: médicos, enfermeiros, assistentes sociais, dentistas e o modelo tecnológico de intervenção alcança seu primeiro apogeu.

As mudanças desses trabalhos configurarão uma nova divisão do trabalho na qual se inscreve o trabalhador coletivo em saude, que corresponde ao conjunto de agentes que atuam no todo que representa o trabalho médico na sociedade. Esses trabalhos, por sua vez, operam interações de suas ações parcelares em novas totalidades, mas sempre orientadas para a finalidade social mais geral do trabalho médico, portanto subordinadas ou dependentes deste e reprodutoras do modo de produção capitalista em seu estágio mais tradicionalista e conservador, o neoliberalismo (MERHY 1987).

A noção trabalhador coletivo em saude foi utilizada por MENDESGONÇALVES (1992) para designar a relação de interdependência e complementariedade destes trabalhadores com base no parcelamento das tarefas, anteriormente centralizadas no médico. Esta individualização das ações e saberes é denominada pelo autor como divisão técnica do trabalho em saude, da qual derivam duas sub-divisões: uma de caráter vertical, quando o processo implica na delegação a outros agentes de tarefas de natureza manual; outra, de caráter horizontal, que 
representaria um compartilhamento do trabalho médico entre seus pares, ou seja, a própria especialização da medicina e a agregação de agentes de áreas complementares e afins.

Ora o médico, situado em um lugar privilegiado na estrutura de ocupações, pode repassar por meio da divisão vertical apenas as dimensões operativas da prestação da assistência, preservando em sua intervenção os signos de alta qualificação intelectual, estabelecendo complementariedades com trabalhos que the são hierarquicamente subordinados e dependentes. Desta forma, mantêm-se relativa autonomia entre as partes e o controle nuclear da intervenção médica, o que propicia amplo dominio sobre a estruturação e o desenvolvimento de sua profissão (MENDES-GONÇALVES 1979; SCHRAIBER 1993; MACHADO 1995).

Entretanto, apesar das interdependências e hierarquias entre as diferentes intervenções serem demarcadas, as hierarquias, muitas vezes, não aparecem de forma muito clara, assim como as interdependências não se distribuem de forma homogênea no modo como são produzidos os diferentes serviços. Decorre daí a necessidade de atenção e certos cuidados com a utilização do conceito de trabalhador coletivo. A chamada divisão horizontal, por exemplo, reflete distintas posições sociais e autoridades técnicas e pressupõe a especificidade de certos procedimentos, que confere certa independência de realização e, também, a quem os conduz, pois relacionam-se diretamente ao tipo de intervenção, de natureza clínica, cirúrgica, diagnóstico e/ou terapêutica, dominios estes bem definidos dentro do processo de trabalho médico e não tão definidos assim no interior dos demais trabalhos em saúde, sobretudo quando estes se articulam diretamente ao trabalho médico. 
No caso da divisão vertical, as subordinações e dominações ficam mais evidentes, pois as dimensões intelectual e operacional foram já demarcadas, como será possivel verificar ainda neste capitulo, como é o caso da relação entre os diversos trabalhadores que compõem a área de enfermagem ou mesmo da relação desta com os profissionais médicos, o que sugere que o trabalhador coletivo apareça mais neste tipo de divisão (MENDES-GONÇALVES Op. Cit.)

Por exemplo, quando transpomos tal perspectiva para o processo de trabalho em saúde mental, entendido aqui como o conjunto de ações técnicas voltadas para o sofrimento psiquico que acomete o ser humano, cuja etiologia passa a ser de ordem individual e social de acordo com a nova psiquiatria, nesse sentido congregando diferentes saberes e especializações, é possível questionar: o trabalho em saúde mental, hoje, expressa qual tipo de divisão, dada essa mudança de modelo? É possível falarmos do conjunto de agentes que atuam na área saúde mental como trabalhador coletivo? Como se revelam as especificidades de cada trabalho em particular? Se tais especificidades conseguem dialogar, traduzem interdisciplinariedades dos diversos saberes que sustentam essas práticas? Qual é a expressão do trabalho interdisciplinar e/ou transdisciplinar? Os trabalhadores de saúde mental constituem-se como "uma" equipe de saude?².

Os trabalhadores de saúde mental, considerados a priori como o trabalhador coletivo, neste estudo, constituem apenas um recorte de um conjunto dinâmico de ocupações que se fizeram presentes na divisão do trabalho em saúde ao longo do século XX.

\footnotetext{
2 A nocão de equipe de saude que adoto tem sido pesquisada por PEDUZZI (1996; 1998; 1999; 2000).
} 
Com a expansão da normatividade médica para âmbitos sociais, inclusive no próprio mundo do trabalho, as práticas médicas, de forma geral, passam a recorrer a intervenções que são originárias de outros campos de atuação, como por exemplo da assistência social e da psicologia e estas, ao atuarem nos processos de saúde-doença, assumem os objetivos da medicina como trabalho social'. Do mesmo modo, tal composição de ações redefinirá a prática médica como prática de saúde determinada socialmente e, portanto, como trabalho: ação técnica de utilidade social, e não uma simples aplicação de um saber com base nas decisões autônomas de seu agente, o profissional (DONNANGELO e PEREIRA 1979; MACHADO Op. Cit.).

As práticas institucionais de saúde no Brasil, por sua vez, em diferentes momentos históricos, demandaram distintas formas de atuação: ações mais voltadas para o coletivo; outras vezes, direcionadas para o individual; em alguns momentos, mais coercitivas e autoritárias; em outros, mais educativas ainda que autoritárias e burocratizadas em essência, e foram marcadas, como dito anteriormente, por certa diversidade profissional, que foi se atualizando ao longo do tempo.

O conjunto dessas ações, destinadas a combater as epidemias urbanas e, mais tarde, as endemias rurais foi denominado por alguns estudiosos como campanhismo e corresponde a um modelo tecnológico de caráter fiscalizador-policial, de inspiração norte-americana. As campanhas sanitárias, uma das atividades desenvolvidas na atuação sanitária brasileira no início da República até final dos anos 20 , concentravam fortemente as decisões, em geral tecnocráticas, cujo estilo repressivo de intervenção médica é predominante (COSTA 1985; LUZ 1991). A reformulação do Serviço

\footnotetext{
${ }^{3}$ Estes aspectos serão aprofundados no capitulo 2, em que apresento os referenciais teóricos que orientaram este estudo.
} 
Sanitário do Estado, em 1917, a criação do Código Sanitário Rural no ano seguinte e da Inspetoria dos Serviços de Profilaxia Geral são algumas formas de institucionalização dessas ações e estes últimos estão na origem dos atuais Centros de Saüde (RIBEIRO 1993).

Quanto às práticas individuais, os agentes habilitados para os cuidados de saúde ainda eram poucos ${ }^{4}$, cuja formação era eminentemente prática. Destacam-se, assim, os enfermeiros, desde há muito tempo responsáveis pelos cuidados e necessidades cotidianas dos doentes, como a administração de medicação e limpeza, a domicilio ou nas enfermarias hospitalares. A produção do cuidado médico se dava de forma individualizada, em gabinetes privados ou consultórios médicos, caracterizando a chamada medicina liberal. Como produção isolada e autônoma, destinava-se a uma clientela heterogênea, mas capaz de pagar pelos serviços; no exercício de uma "medicina para os pobres", valer-se-ia de amplo conjunto de ações ligadas à hospitais filantrópicos (PALMA Op. Cit.). A concepção e entendimento do hospital ${ }^{5}$ como um "prolongamento" dos consultórios privados redimensiona o trabalho médico, que seria desdobrado em diversas modalidades assistenciais, congregando novos processos de trabalho, objetos, instrumentos e agentes (DONNANGELO 1975).

Compreendendo a conjuntura de ascendência e hegemonia do Estado populista (WEFFORT 1975), observa-se a criação das Caixas de Aposentadoria e Pensões (CAP's) e dos institutos de seguridade social (os IAP's), organizados por

\footnotetext{
4 Até metade do século XIX, os cuidados relativos a doença, conduzidos individualmente, eram praticados por um conjunto de agentes não licenciados. Entre os agentes habilitados, encontravam-se os cirurgiões-barbeiros, boticários e fĩsicos, cujas práticas estão na origem da odontologia e cièncias farmaceuticas modernas.

క Os serviços hospitalares, de forma geral, tèm sido muito estudados pela literatura sociológica européia, sobretudo por FOUCAULT (Op. Cit.) e, mais recentemente, por CARAPINHEIRO (1993).
} 
categorias profissionais, que favoreceram determinados grupos de trabalhadores urbanos mais ligados a sindicatos, cujo trabalho era importante para a economia agroexportadora até então dominante: ferroviários, portuários, empregados do comércio, bancários. funcionários públicos, ocupações diretamente atreladas e indispensáveis para a economia industrial em ascensão (OLIVEIRA e TELXEIRA 1986).

Com efeito, o resultado das novas condições de vida e trabalho, tais como miséria, insalubridade e doença, passava a ser considerado como causa dos problemas de saúde, portanto de natureza social, decorrendo daí a necessidade de contê-los por meio da conexão entre os serviços de saúde e demais instituições: escolas, fábricas ou domicilios carentes. Destaca-se nesse modelo educativo a origem de diversas práticas que viriam a configurar o trabalho de nutricionistas, enfermeiras de saúde pública e visitadoras sanitárias; mulheres jovens, em sua maioria, egressas das Escolas Normais, sendo que as últimas se diplomariam como Educadoras Sanitárias.

Em 1931, já sob o regime de interventoria, Saúde e Educação compuseram a mesma Secretaria em São Paulo e a educadora sanitária passaria a ser a principal auxiliar do médico sanitarista, desenvolvendo algumas ações de enfermagem e de serviço social. O Serviço Sanitário do Estado, por sua vez, sofre outras mudanças, quando ex extinta a Inspetoria de Higiene dos Municipios e substituída pelas antigas Delegacias de Saúde no Interior e na Capital e pela Inspetoria de Higiene Escolar e Educação Sanitária (PALMA Op. Cit.)

Entre 1932 e 1940, como expressão do clientelismo caracteristico da Era Vargas, são criadas várias instâncias de formação e organização do serviço social no Estado de São Paulo, para dar conta das demandas sociais atreladas à saúde. 
Primeiramente, a criação do Centro de Estudos e Ação Social (CEAS), ligado à Igreja Católica, destinado a dinamizar a filantropia burguesa paulista que, em 1936. culminaria na Escola de Serviço Social; a constituição da Comissão de Assistência Social do Estado de São Paulo, composta pela burguesia paulistana, cuja principal atribuição era a promoção de iniciativas de assistência social voltadas, principalmente, para crianças, enfermos e inválidos, sobretudo em creches, hospitais e asilos; o Departamento de Assistência Social do Estado, que reforçava os serviços destinados àquela clientela, bem como a infratores, dentro e fora das instituições; e o Instituto de Serviço Social, voltado especificamente para os novos trabalhadores da indústria (PUC 1994).

Com o Estado Novo, é criado, em 1938, o Departamento de Saúde do Estado em substituição ao Serviço Sanitário, quando os setores da saúde e da educação se separam. A reorganização do novo departamento de saúde seria composta por duas divisões, uma administrativa e outra técnica, à qual estariam subordinados diversos serviços, destacando-se os serviços de Centros de Saúde da Capital e do Interior, os serviços de Fiscalização do Exercício Profissional e da Alimentação Pública, os serviços de profilaxia de doenças infecto-contagiosas e os serviços de Assistência Hospitalar e Assistência à Psicopatas.

Segundo ANTONACCI (1993), essa nova complexidade organizacional, deflagrada pelo cientificismo que acompanhou a estruturação produtiva em curso na sociedade, refletia os contextos politico-sociais, nacional e internacional. No caso do Brasil, toda a década de 30 é marcada por intensos conflitos sociais, que podem ser representados pela ascensão do movimento operário; por tentativas insurrecionais, 
como a da Aliança Nacional Libertadora; pelo avanço do movimento integralista e do fascismo e a intensa repressão social que expressavam. $O$ contexto internacional é, também, fortemente marcado pelo autoritarismo facista e nazista e por episódios como o da Guerra Civil Espanhola, que antecederam a segunda guerra mundial.

Ainda perseguindo os moldes de um modelo de educação sanitária, a nova organização priorizou, em principio, o Serviço de Centros de Saúde da Capital, cujo conjunto de atividades era voltado para a prevenção dos agravos à saúde, com atenção especial à infância e ao controle de doenças venéreas, e a seguir, à assistência hospitalar.

A estrutura hospitalar na cidade de São Paulo, de forma geral, passou por várias mudanças, percebidas, desde 1935, quando a divisão do trabalho e os novos tipos institucionais assumiram maior complexidade ${ }^{6}$. Nesta configuração, notas-se grande concentração de enfermeiros e médicos, e entre estes, a prevalência de especialidades cirürgicas, sobretudo nas Santas Casas e Hospitais Beneficentes. A partir de 1940, entretanto, novos especialistas são incorporados ao trabalho hospitalar, tais como o nutricionista, que passaria a assumir trabalhos até então pertencentes à enfermagem, tais como: supervisão de dietas e dos serviços da cozinha; dos desdobramentos técnicos da enfermagem e do reconhecimento de sua importância para a assistência primária, os enfermeiros de saúde pública viriam substituir as educadoras sanitárias, que requalificadas profissionalmente, seriam substituídas por visitadores sanitários e dariam origem a outro profissional de nível superior: o educador de saúde pública. 
O Serviço de Assistência Hospitalar, responsável pelos hospitais públicos e privados gerais e pela distribuição de auxilios e subvenções, neste mesmo ano, é desvinculado do Departamento de Saúde do Estado e subordina-se diretamente ao Secretário de Educação e Saúde Pública sob a denominação de Serviço de Medicina Social (PALMA Op. Cit.).

No que se refere à saúde mental, o Serviço de Assistência à Psicopatas estruturou-se pelo conjunto dos hospitais psiquiátricos públicos existentes na Capital e no Interior, que incluia o Hospital e as Colônias do Juqueri, inaugurado em 1898 e o Manicômio Judiciário, de 1927, e por clínicas especializadas que marcaram a introdução de novos métodos terapêuticos, que viriam a retomar e aprofundar o enfoque biológico ou anátomo-patológico da psiquiatria, bem como a experimentação cientifica em seres humanos: a insulinoterapia, o choque cardiozólico e a eletroconvulsoterapia, além de cirurgias cerebrais mutilantes (PEREIRA 1996). A utilização em larga escala dessas novas terapias foi propiciada pela transferência dos doentes mentais das cadeias para os hospícios e pelo recolhimento sistemático de mendigos. Os "critérios de melhora" de seus quadros eram medidos pelo grau de obediência e bom comportamento (MACHADO et. al. 1978).

Em 1941, o Serviço de Assistência à Psicopatas também ficou ligado diretamente ao Secretário pela Diretoria de Assistência aos Psicopatas, que passou a responder por toda a estrutura de asilos, laboratórios e dispensários. Por volta de 1942, as técnicas de eletrochoqueterapia criariam uma seção especializada no Juqueri, destinada a "um melhor ajustamento dos pacientes ao meio hospitalar". Nota-se que a

\footnotetext{
- Neste ano, existiam em São Paulo 4 hospitais do tipo Santa Casa; 3 hospitais beneficentes: 9 casas de saúde e 2 maternidades, além de 5 que estavam em construção (CENSO HOSPITALAR DE 1935
} 
introdução de modernas tecnologias, como a eletronarcose, o coma elétrico e a atualização das lobotomias, iniciadas em 1936, marcam a psiquiatria contemporânea e o processo de especialização de seus agentes, tanto os médicos psiquiatras, como os neurologistas, neuropatologistas e neurocirurgiões, entre outros, e também as equipes de enfermagem, que passavam a auxiliar tais práticas cirúrgicas e terapêuticas. Ao mesmo tempo, foram ampliados os ambulatórios, permitindo maior articulação entre a assistência ambulatorial e hospitalar, com o intuito de evitar intemações e reinternações, com a administração de novas drogas para as depressões e antagonistas do álcool, que já anunciavam a pesquisa de novos psicofärmacos, que viriam a revolucionar o tratamento ambulatorial (PEREIRA Op. Cit.).

Quanto à formação desses profissionais, é possivel observar neste mesmo periodo, a criação de diversos cursos técnicos, de graduação e de especialização que pretendiam adequar tecnicamente e legitimar socialmente essas práticas frente às novas demandas, principalmente com a iminència da Segunda Guerra Mundial. Ainda em 1940 é criado um Curso de Dietistas junto ao Instituto de Higiene, que desde inicio do século $\mathrm{XX}$ constituiu-se em um centro de pesquisas e qualificação profissional em saúde de grande importância no cenário nacional; em 1942, é criada a Escola de Enfermagem da Faculdade de Medicina da USP e em 1944 o Hospital das Clínicas da Faculdade de Medicina da Universidade de São Paulo é inaugurado, consagrando a era da medicina tecnológica (SCHRAIBER Op. Cit).

O periodo pós -45 , periodo de efetivação da nova medicina, ficou conhecido como o periodo do desenvolvimentismo, que se inicia com a tentativa de implantação 
de um projeto nacional de desenvolvimento econômico moderno e termina com a crise do regime populista nos anos 60 (WEFFORT Op. Cit.). Quanto às politicas de saúde, o modelo campanhista em seu estágio mais burocratizado ainda predominava nos órgãos de saúde pública, opondo-se sistematicamente ao modelo curativista, dominante nos serviços previdenciários de atenção médica, igualmente burocratizados e incompativeis com as demandas de saúde, tanto da população urbana como da rural. Uma tecnoburocracia médica, diplomada no exterior em administração dos serviços de saúde, assumira a gestão dos Institutos de Previdência na tentativa de combater a ineficiência e justaposição dos programas e serviços criados nos anos precedentes, marcados pelo intenso controle estatal.

Tais medidas redundaram no aumento da dicotomia saúde pública e atenção médica individual. Se as condições de vida da maior parte da população não pioraram, a consciência dessas condições foi se tornando cada vez mais clara. Dada a impossibilidade de soluções reais por parte das instituições, essa tomada de consciência originou um impasse nas políticas de saúde, percebido como um reflexo direto da própria crise institucional e política (LUZ 1979).

Uma primeira tentativa de resposta à crise foi o grande movimento social do inicio dos anos 60 no pais, liderado e conduzido pelas elites progressistas que reivindicavam reformas de base imediatas, entre as quais uma reforma sanitária consistente (ROSÁRIO 1986). Contudo, a reação politica das forças sociais conservadoras a essas reivindicações foi uma das causas do golpe militar de 1964, comprometendo os vinte anos seguintes com a ditadura militar. No que concerne às políticas de saúde, os primeiros quatro anos do regime autoritário implicaram uma 
reorientação instituicional, com o "enxugamento" da máquina estatal, que se operou em todos os setores administrativos (SANTOS 1986).

Os anos seguintes correspondem à fase do chamado milagre econômico. No plano político, atos institucionais e decretos presidenciais tinham o poder de modificar a Constituição no tocante aos direitos de cidadania, informação e comunicação social, bem como o de controlar o exercício dos poderes Legislativo e Judiciário (TEIXEIRA 1987). A politica econômica preconizava um crescimento acelerado com elevadas taxas de produtividade, conjugada a baixos salários para grande parte da massa trabalhadora, desfavorecendo a maioria das categorias ao mesmo tempo em que favorecia os trabalhadores especializados, os técnicos e os quadros superiores empregados nos setores de ponta da economia (MARTINS 1985).

A partir de então, estabeleceu-se um política de saúde em consonância com as novas diretrizes politicas, que realizava uma sintese do sanitarismo campanhista, oriundo da Primeira República, e da atenção previdenciária do periodo populista, cuja principal estratégia era a medicalização social (OLIVEIRA e TEIXEIRA Op. Cit.).

A saúde passa, então, a ser vista como um bem de consumo, ou melhor, um bem de consumo médico. Generalizou-se a demanda social por consultas médicas como resposta às graves condições de saúde da população; o elogio da medicina como sinônimo de cura e de restabelecimento da saúde individual e coletiva; a construção ou reforma de inúmeras clínicas e hospitais privados, com financiamento da Previdência Social; a multiplicação de faculdades particulares de medicina por todo o paí; a organização e a complementação da política de convênios entre o INPS e os 
hospitais, clinicas e empresas de prestaçăo de serviços médicos, em detrimento dos recursos, já parcos, tradicionalmente destinados aos serviços públicos.

Esta politica facilitava a predominância de um sistema de atenção médica 'massificada', em detrimento da medicina social e preventiva que chegou a ser preconizada antes do golpe, reforçado pelo surgimento e rápida expansão da chamada medicina empresarial ou de grupo e pelo atrelamento da indústria farmacêutica e de equipamentos médico-hospitalares ao ensino médico, cada vez mais voltado para a especialização e sofisticação tecnológica, totalmente desvinculado da realidade sanitária brasileira (LUZ 1982; SCHRAIBER 1989).

Tais diretrizes autoritárias da politica de saúde deflagaram, a partir de 1976, grande insatisfação popular e, tambem, por parte de outros setores da sociedade civil: quebra-quebra de ambulatórios, crise da Previdência Social denunciada publicamente, movimentos sociais de internos e residentes médicos, que buscaram articulações com outros movimentos sociais para lutar contra a política do regime, denúncias de médicos sobre o processo de massificação das consultas nas instituições públicas denunciavam a má qualidade dos serviços prestados à população. Nesse contexto, verifica-se a emergência de programas como os de Saúde Materno-Infantil, que também apresentavam um caráter ideológico, na medida em que estiveram articulados às propostas de racionalizar as politicas sociais que mantinham as estruturas sociais injustas, legitimando o Estado diante da crise econômica e politica do Milagre Brasileiro (GOMES 1988).

Os movimentos sociais reivindicando melhorias para a saúde cresceram em número e intensidade, de tal modo que, entre o final dos anos 70 e $\circ$ início dos anos 
80, sindicatos, partidos, universidades, associações de moradores, igreja discutiam a vertiginosa degradação das condições de vida da população e os altos índices de doenças infecto-contagiosas a que estavam expostos e exigiam soluções para os problemas criados pelo modelo de saúde do regime autoritário: centralizador, conservador, privatizante e ineficaz (COHN 1994).

\subsection{As políticas de saúde na transição democrática}

A reorganização do país em direção a um Estado de direito desenvolveu-se lentamente e de maneira conflituosa. Com as eleições de 1982, as negociações entre as forças politicas mais conservadoras e moderadoras se sucederam, na busca da ampliação da 'abertura democrática'. Ainda assim, tais negociações colocaram em plano secundário os sindicatos e partidos de esquerda, recém saídos da clandestinidade, apesar de seu sucesso eleitoral nos anos de 1982 e 1984 e os resultados das eleições de 1986 favoreceram as forças conservadoras (TEIXEIRA Op. Cit.).

Nesse periodo, as políticas públicas desempenharam um papel muito importante na consolidação da nova ordem sócio-política que, desde sua origem, manteve traços antidemocráticos cujas raizes penetram profundamente nas estruturas existentes, fundindo-se a interesses sociais objetivos e contraditórios entre si. Tais condições não podem ser modificadas em poucos anos, ou pela passagem de uma conjuntura a outra, o que reforçou a situação de exclusão da maior parte da população. 
Os interesses contraditórios, enraizados no solo político brasileiro, se manifestam com muita intensidade nas políticas de saúde, na medida mesma da importância histórica dessas políticas. As proposições de uma mudança estrutural através de uma reforma sanitária, por exemplo, têm sido impedidas por obstruções, boicotes, desentendimentos e distorções colocadas por tais interesses, internos e externos às instituições de saúde. Isso dificulta que, para alèm dos discursos e das normas, a prática institucional experimente transformações consistentes (LEITE 1991).

No caso particular das proposições para uma nova política de saúde, em debate no cenário nacional desde a primeira metade dos anos 80 , é necessário sublinhar a novidade e a originalidade de certas práticas institucionais e a oportunidade do surgimento de outras, nos domínios da participação popular em serviços de saúde e da descentralização institucional (COHN Op. Cit.).

Ora, o confronto de interesses econômicos e políticos no interior do campo da saúde, e a conseqüente luta pela ocupação dos diferentes espaços institucionais por representantes desses interesses, se desenvolveram tanto no campo macroanalitico como no microanalítico do poder, isto é, no âmbito ministerial e também em hospitais, ambulatórios e unidades municipais de saủde. Os discursos e os saberes das diversas corporações profissionais envolvidas na questão da saúde (médicos, enfermeiros, assistentes sociais, psicólogos) também foram (e têm sido) um foco de luta política no cruzamento desses niveis de disputa pelo poder, no tocante à elaboração das diretrizes institucionais e conquista de hegemonia. 
Nos últimos anos da década de 80 , nesse contexto de lutas no nivel dos discursos, das práticas e das estratégias políticas pela reforma das instituições de saúde, manifestaram-se os impasses das políticas sociais. Tais politicas, próprias dos países em desenvolvimento, voltadas para a construção de uma ordem democrática, conjugaram, ainda, grandes interesses sociais e econômicos, externos e internos, que perpetuaram uma ordem social extremamente concentrada, em termos politicos e econômicos.

Essa oposição de interesses encontra sua expressão mais acabada na alternância de orientação e de proposições para o setor: a uma orientação privatizante e internacionalizante contrapõe-se uma orientação estatizante e nacionalizante. Ambas as tendências experimentam conflitos internos e a defesa do que deveria ser ou não 'nacionalizado', isto é, estatizado, suscitou discussões e divergências profundas mesmo entre os que apoiavam esse caminho. Cabe ressaltar que, ainda neste momento, à privatização estava associada a idéia de internacionalização, sendo que já na década seguinte tal processo será notado em grande parte das empresas estatais brasileiras.

A gestão, a distribuição, o financiamento e a avaliação dos serviços de saúde; os aspectos sociais e políticos dos atos médicos, isto é, a maior ou menor intensidade da medicalização do social; a integração e a hierarquização dos serviços segundo o grau de complexidade, desde as unidades de cuidados primários ate os hospitais mais complexos e especializados, são outros pontos em torno dos quais discussões e conflitos foram igualmente intensos (NEMES 1990). 
Portanto, o debate privado $x$ estatal ou nacional $x$ internacional, recorrente no discurso da política de saúde desde os anos $50^{7}$, assume uma caracteristica nova e, talvez, original nos anos 80 , com a entrada em cena do empresário de saúde como um atör político que defende publicamente seus interesses, com lobbies no Congresso e nas Assembléias Legislativas, nos Ministérios da Saúde e da Previdência Social, nas instituições formadoras de recursos humanos (faculdades e hospitais universitários) e nos serviços públicos estaduais e municipais da área.

Outra perspectiva importante nestes anos foi a tomada de consciência por parte da sociedade civil, do papel da saúde e das instituições médicas na vida coletiva. A compreensão desse papel tomou claro que são os próprios trabalhadores que financiam, através dos descontos em folha e impostos, os serviços médicos da Previdência Social e do Ministério da Saúde, que deveriam, antes de tudo, servi-los. Essa tomada de consciência evidenciou as oposições ideológicas subentendidas em diversos temas de debate. Por outro lado, os interessados tiveram a oportunidade de perceber que tais oposições não são recentes. Em última instância, fazem parte da história das politicas sociais do pais (SADER 2000).

Todos os grupos envolvidos no debate das políticas de saúde dos anos 80 estiveram de acordo quanto ao papel do Estado como coordenador e gestor dos planos, programas e serviços de saúde. Os setores progressistas reivindicaram mesmo uma ampliação desse papel, fazendo desse ponto uma 'questão fechada' da reforma sanitária.

\footnotetext{
- De acordo com Zioni (2000), a partir dos anos 50, para a compreensão das políticas públicas de saúde e sua relação com o contexto histórico em que se inscrevem, é necessário que a leitura desses
} 
Essa reivindicação encontrou, entretanto, um obstáculo na estrutura privada de atenção médica. solidamente construída durante os anos 70. Apesar disso, foram dados alguns passos rumo à contenção da politica de convênios com o setor privado. A rede privada chegara a ser financiada em mais de $80 \%$ pelo Estado. Durante curtos períodos conjunturais, entretanto, novos programas e serviços públicos foram criados e mantidos, em oposição à situação de quase abandono em que haviam sido relegadas instituições e serviços públicos no final dos anos 70 .

Algumas medidas foram tomadas no sentido de facilitar o acesso da população aos serviços de saúde. O governo da Nova República favoreceu a descentralização dos serviços em niveis municipal e distrital, por meio de programas pilotos, e procurou institucionalizar a 'participação popular' nos mesmos serviços, ratificando uma tendência que já vinha do inicio dos anos 80, com as Ações Integradas de Saúde (AIS).

A concepção da saúde como um 'direito civil', ou seja, um direito do cidadão e um dever do Estado, é a segunda grande oposição de base em relação aos temas especificos de politica para o setor. Essa questão suscitou acaloradas discussões até outubro de 1988, quando a nova Constituição reconheceu formalmente este direito social de cidadania, tanto tempo postergado pela República (DALLARI 1987).

Entretanto, para certos setores da sociedade, principalmente entre empresários e também entre alguns setores sindicalistas, a saúde é um direito que se adquire pelo trabalho. Trata-se da visão tradicional nas politicas sociais brasileiras, que relaciona a aquisição de direitos sociais ao exercício do trabalho, sobretudo o trabalho urbano. 
Trata-se, portanto, em última instância, do exercicio do emprego. Essa concepção tomava os serviços médicos inacessíveis à maior parte da população brasileira: crianças, donas de casa, velhos sem aposentadoria, desempregados, sub-empregados da economia informal.

A percepção social da saúde como direito de cidadania é um dado novo na história das politicas sociais brasileiras e pode ser entendida como fruto dos movimentos sociais de participação em saúde da segunda metade dos anos 70 e do início dos anos 80 (MATTOS 1990). Nesse sentido, a própria reforma sanitária pode ser vista como um elemento novo no cenário político do pais, um elemento instaurador de uma politica de saúde institucionalmente inédita. Em outro sentido, o lema "Saúde, direito de cidadania, dever do Estado" implica uma visão desmedicalizada da saúde, na medida em que subentende uma definição positiva, diferente da visão tradicional, que identifica saúde com ausência relativa de doença.

Sob esta nova definição, a noção de saúde tende a ser socialmente percebida como expressão ativa, participativa do exercicio de direitos de cidadania, entre os quais o direito ao trabalho, ao salário justo, à participação nas decisões e gestões de políticas institucionais etc. Assim, a sociedade tem a possibilidade de superar politicamente a compreensão, até então vigente ou socialmente dominante, da saúde como uma condição apenas biológica, de normalidade ou ausência de patologia.

Datada dos anos 80 , a nova concepção de saúde é muito recente na sociedade brasileira e ainda se restringe a grupos partidários e movimentos sociais de vanguarda. Mas a nova Constituição já incorporou uma definição próxima dessa noção. Além desse avanço, as lutas pelo acesso aos cuidados de saúde, pela participação na gestão 
e na coordenação dos serviços pela não-privatização das instituições de saúde são, entre outras, importantes pontos que uitrapassam os marcos institucionais das políticas de saúde, atingindo os da política social como um todo (LEITE Op. Cit.).

No contexto de transição democrática, alguns aspectos mais estruturais das políticas de saúde foram redefinidos e merecem atenção pelo seu caráter estabilizador dessa nova ordem política: a reforma sanitária, com a criação e implementação do SUS - Sistema Único de Saúde (NEMES Op. Cit.).

A reforma sanitária contribuiu para transformar a história das políticas sociais e de saúde no Brasil e representou uma exigência de mudança estrutural, contando com o engajamento de vários setores políticos da sociedade. Opor-se à reforma ou negá-la significava opor-se à realização da própria transição política, pois um regime democrático estável não poderia institucionalizar-se ou manter-se sem a implantação de politicas sociais capazes de liquidar a famosa 'divida social brasileira', freqüentemente mencionada nos discursos dos politicos brasileiros.

Algumas estratégias de resistência às transformações se fizeram sentir, ao pretenderem identificar lideres politicos e quadros intelectuais ligados à defesa das novas políticas a anarquistas, comunistas e populistas, sinônimos na tradicional linguagem conservadora brasileira, mas apesar disso dois eventos importantes marcaram o reconhecimento da necessidade de uma reforma sanitária em caráter de urgência: a $8^{a}$. Conferência Nacional de Saúde, realizada em Brasilia em 1986 reuniu cerca de quatro mil pessoas e a instalação da Assemblëia Nacional Constituinte, um ano depois, deveria incluir os principios fundamentais da reforma sanitária na nova Constituição brasileira, finalmente sancionada em 1988 (DALLARI Op. Cit.). 
O debate acerca dos caminhos e diretrizes da reforma continuou ao longos dos anos 1987 e 1988, envolvendo diversos grupos de esquerda contra conservadores neoliberais. As divergências eram nitidas, não apenas entre esses grandes setores de base, mas também entre os grupos de esquerda, que competiam muitas vezes por posições e situações de controle dentro do aparelho de Estado, em nome de projetos ou principios discordantes.

As discussões se acirraram, sobretudo, em tomo de questões fundamentais, como finalidades, diretrizes e métodos da reforma sanitária; estratégias e táticas necessárias e adequadas para assegurar a legitimidade e irreversibilidade de suas conquistas.

Um dos pontos nevrálgicos dessas discussões foi a unificação das instituições e serviços de saúde em um só Ministério - o da Saúde, que deveria ser o responsável, em diferentes niveis, pela reforma sanitária e por toda a política de saude. $E$, neste aspecto, uma antiga dificuldade se recoloca: lidar com a descentralização e conseqüente distribuição do poder institucional (SORRENTINO 1997).

O tema da unificação institucional da saúde reaparece, mas com outros elementos. A premente superação da dicotomia entre saúde pública e atenção médica curativa e a construção de um novo modelo, integrando a medicina preventiva e cuidados médicos individuais previdenciários, dependeriam de uma concreta integração das diversas instituições e instâncias politicas de saúde, que favorecesse o fim da justaposição, competição e ineficácia de programas e serviços de saúde e promovesse o "saneamento" orçamentário de tais ações. Ao mesmo tempo, assinalava a possibilidade do Estado retomar a direção politica da atenção médica previdenciária. 
E, apesar de todas as pressões e resistências por parte daqueles grupos populistas e economicamente comprometidos, em 1987, venceu a tendência para a unificação dos serviços institucionais de saúde, com o Sistema Unificado e Descentralizado de Saúde, o SUDS, na Previdência Social. Com a nova Constituição, isso foi confirmado, através da proposição do Sistema Único de Saúde (SUS). Mas, ainda hoje, permanece problemática a efetiva distribuição do poder institucional, principalmente entre os diversos grupos politicos divergentes.

Apesar do tema da descentralização ser recorrente desde os anos 50 , podendo ser observado com freqüência nos discursos reformistas da politica de saúde, na nova conjuntura democrática assume novo caráter, devendo expressar uma "desconcentração" efetiva de poder, não apenas no nível das instituições de saúde, mas, sobretudo, entre os setores mais avançados politicamente, tais como: associações comunitárias, associações profissionais, sindicatos e movimentos de saúde. Os profissionais de saúde, por sua vez, reivindicavam uma transferência efetiva de responsabilidade, com poder de decisão, para estados, municipios e distritos, extrapolando a concepção puramente geo-política da descentralização.

Nesta direção, para garantir que a descentralização atingisse todos os níveis e aspectos institucionais dois mecanismos, também recorrentes na história das políticas brasileiras de saúde, são atualizados: a chamada hierarquização dos atos e serviços médicos e de saúde e a criação dos conselhos municipais e interinstitucionais de gestão dos serviços de atenção à saúde (COHN Op. Cit.).

A hierarquização dos atos médicos segundo sua complexidade e especialização revelavam a prioridade a ser dada a cada um, desde os mais simples e 
gerais aos mais complexos e especializados. No que diz respeito à atenção primäria. conjunto de cuidados mais freqüentes entre a população-alvo dos serviços de saúde pública, o reconhecimento de sua prioridade em relação aos cuidados mais sofisticados, ditos terciários, já se delineava desde os anos 60 e o seu debate conduzido por médicos da saúde pública envolveu clínicos de hospitais gerais e alguns liberais ligados à Previdência Social. Aos cuidados primários atrelar-se-iam os secundários, no caso de doenças crônicas e emergências que, por sua vez, teriam a retaguarda dos serviços hospitalares terciários (SORRENTINO Op. Cit.).

Em lugar dos serviços prestados por hospitais altamente especializados, passariam a ser priorizados os atos médicos generalistas, levando em consideração as necessidades mais imediatas de atenção à saúde da maioria da população. Tal orientação se opunha à tendência dominante na medicina científica moderna, que privilegia a sofisticação técnica desde o inicio da intervenção médica, que se torna altamente especializada e voltada para a novidade ou raridade de determinadas doenças, em detrimento de doenças tidas como mais corriqueiras. Ou seja, a reestruturação dos serviços médicos e a organização de um sistema unificado e integrado passariam a contemplar o perfil de adoecimento em nivel populacional, e salientavam o aspecto da qualidade desses cuidados médicos e de saúde voltados para a população de baixa renda.

Compreendendo, ainda, as diferentes corporações profissionais envolvidas nesse processo (médicos, enfermeiros, assistentes sociais, psicólogos, nutricionistas, entre outros) e os demais setores organizados, o movimento social centrado na saúde colocava em questão qualquer projeto de organização de uma rede de cuidados 
baseada em atenção primária que se limitasse a ser uma medicina pobre destinada aos pobres.

$\mathrm{Na}$ segunda metade dos anos 80 , na conjuntura de transição do regime político, sindicatos, associações e profissionais ligados à questão da saúde, bem como partidos políticos, discutiram seriamente as relações entre instituições e profissionais de saúde, de um lado, e profissionais de saúde e população-alvo de outro. $\mathrm{O}$ reconhecimento da necessidade de democratizar essas relações cresceu em vários fóruns de discussão, desde a $8^{a}$. Conferência Nacional de Saúde às mais recentes, bem como nas Conferências Municipais e Estaduais (MS 2001).

A formalização da participação popular nos serviços de saúde, por sua vez, pode ser identificada no cenário de lutas brasileiras desde os anos 50 , sob a designação de participação comunitária. Apresentando novas aspectos na atualidade, busca superar a condição de participação comunitária, coerente com os discursos desenvolvimentista e populista, e propõe medidas a serem tomadas pelo Estado, no sentido de garantir a democratização das decisões nos niveis do planejamento, gestão, execução e avaliação dos serviços e programas de saúde. Os conselhos integrados de saúde, compostos por representantes das instituições públicas e privadas, representantes de sindicatos e de associações comunitárias deveriam ser, em principio, a base da pirâmide institucional, a partir da qual se organizaria a politica de saúde. Como aponta ROSÁRIO (Op. Cit.), apesar de a vanguarda do movimento considerar tal participação limitada, tal projeto ainda se defrontou com os inevitáveis interesses e orientações políticas divergentes, a secular tendência à centralização e à concentração 
do poder institucional e permanência dos poderosos núcleos clientelistas e populistas, incrustados nas instituições de saúde há mais de meio século.

Entretanto, algumas experièncias localizadas desenvolveram-se e se mantiveram com a abertura politica dos anos 80 , quando governantes eleitos por partidos progressistas encorajaram o debate e a inovação instituicional entre os atores políticos em presença. Nessas experiências, talvez esteja, ainda, a possibilidade de transformação das politicas de saúde no Brasil que possam originar avanços para a concretização da democracia, na qual os direitos sociais sejam respeitados, quer para a clientela, quer para os profissionais de saúde.

\subsection{Novos panoramas da assistência à Saúde Mental em São Paulo: os anos 80 e 90}

O uso da denominação Saúde Mental em detrimento da doença mental remonta à Segunda Guerra Mundial e se refere à 'nova psiquiatria', entendida como o conjunto de saberes e práticas psiquiátricas levado a efeito no contexto internacional e que vem se contrapondo a um modelo dito tradicional (BIRMAN e COSTA 1976; FERNANDES 1999). Na esteira deste movimento de rupturas, as políticas de saúde mental se organizaram pela confluência de três fatores: a critica ao hospital e a luta antimanicomial, a falência do modelo previdenciário e o reconhecimento da necessidade de ação supletiva da saúde pública na assistência psiquiátrica (GIORDANO JR. 1989). 
Neste contexto de mudança, introduziram-se as proposições da Medicina Comunitária, de inspiração norte americana, nas quais estavam contidos os conceitos que orientariam a compreensão de doença mental que viria a seguir: processo saúdedoença, entendido em sua dimensão integral, isto é, 'o todo biopsicossocial' e a história natural da doença. Foi neste dominio da saúde pública que se verificaram movimentos crescentes no sentido da reformulação assistencial em direção à organização que se concretizaria, ao menos em termos de propostas oficiais, em equipamentos e equipes instaladas por volta dos anos 80 (MEDEIROS 1977; BUSNELLO 1976; ARCARO 1990).

As matrizes conceituais dessas propostas remontam a 1976 e à reforma administrativa da gestão Walter Leser, considerada ponto de partida para a instauração de um novo modelo tecnológico na saúde pública paulistana, na qual foi elaborada a minuta que estabelecia o modo de integração entre a Coordenadoria de Saúde da Comunidade (CSC) e a Coordenadoria de Saúde Mental da Secretaria do Estado da Saúde de São Paulo, com vistas à elaboração de um sub-programa, cujos objetivos gerais seriam: redução dos riscos de morbidade psiquiátrica, elevação dos niveis de saúde mental, promoção de ações de melhoria dos níveis de saúde mental dentro dos programas de crianças, adultos e gestantes, mediante detecção precoce e intervenção adequada, aumento do atendimento ambulatorial de pacientes psiquiätricos, mediante ações de reabilitação. Tais ações se expressaram em forma de atividades como pré-consulta, atendimento de enfermagem de rotina, consulta médica de rotina e eventual, atendimento psicológico de rotina e eventual, pós-consulta, 
atendimento eventual do serviço social, trabalho em grupo para atendimento em saúde mental, convocação e visita domiciliar (SES 1976).

Esse documento reformulava as propostas embasadas pelo referencial epídemiológico, estabelecendo para a área de saúde, em geral, normas e diretrizes para diversos programas e, para a saúde mental, inaugurava uma nova forma de abordagem, incluindo-a entre as demais programações de saúde (NEMES 1996). Apesar disso, em 1980, ○ Estado de São Paulo continuava privilegiando o atendimento hospitalar, sendo que em sua grande maioria, em torno de $92,6 \%$, este atendimento era realizado por instituições privadas (MACEDO 1981; PITTA HOISEL Op. Cit.).

SÁ (1983), ao abordar a evolução histórica do hospital psiquiátrico do Juqueri, sua organização e sua "inclusão" na paisagem metropolitana, a população de internados e de servidores, em diferentes niveis ocupacionais, verifica que o Juqueri esteve ausente dessa reformulação das políticas públicas de saúde mental e mesmo do planejamento em saúde para a Região Metropolitana, de uma forma geral. Acrescenta que a Instituição perecia do que chamou de "pobreza organizacional e de recursos humanos", quando comparada a outras instituições similares e que suas "características de cidade" demandavam modelos e condições excepcionais que extrapolaram os limites (intelectuais e técnicos) da administração pública brasileira. 
Ao mesmo tempo, foi foco de permanentes críticas de dois campos em crise: de um lado, o sistema carcerário ${ }^{8}$ e do outro, o Movimento Antimanicomial e o questionamento e a busca da racionalização da própria hospitalização psiquiátrica".

Ao estabelecer equipes de saúde mental em todos os centros de saúde e criar os ambulatórios de saúde mental, cujo projeto assistencial era centrado na atenção multiprofissional extra-hospitalar e na participação dos usuários, a Coordenadoria de Saúde Mental do Estado delineia ações e atribuições para cada profissional que viria a integrar as equipes de saude mental da rede pública. $O$ grupo de trabalho era composto por médicos, psicólogos, assistentes sociais, enfermeira, terapeuta ocupacional e fonoaudióloga e o resultado foi a elaboração da Proposta de Trabalho para Equipes Multiprofissionais em Unidades Básicas e em Ambulatórios de Saúde Mental (SES 1983).

Observa-se, assim, a implementação de uma política de saúde mental nos moldes preventivistas durante o governo Montoro, que classifica a assistência ambulatorial como sendo de nivel secundário e que se estrutura segundo o modelo programático, em que mecanismos de avaliação são entendidos como parâmetros da qualidade do serviço oferecido (PITTA 1992; POMPEI 1996).

A maioria dos ambulatórios foi inaugurada em meados dos anos 80, priorizando e/ou direcionando seu atendimento a uma demanda especifica, com algum nível de sofrimento psiquico e seu objetivo central, como dito anteriormente, inserido

\footnotetext{
${ }^{8}$ Outros aspectos sobre o debate institucional saúde e justiça no manejo de transtornos mentais podem ser encontrados em SA ENC. O manicòmio judiciário: saúde ou justiça? In: Rev. saúde pública 1985; 19(5):389-400; SÁ e PIMENTEL. Juqueri: o espinho adormecido - parte 1. São Paulo: Hucitec; 1991 (Saúde em debate, 39).

9 Sobre a continuidade e as novas concepçôes acerca da hospitalização psiquiátrica, ver: FIGUEIREDO (1996) e FERNANDES et. al. (1999).
} 
na problemática da redução da internação hospitalar e no aumento do acompanhamento sistemático e integral a psicóticos, em que desenvolvem ações de cuidados que transcendem a oferta exclusivamente medicalizante, caracteristica do ambulatório tradicional que se buscou superar, e intervenções pautadas em principios éticos que envolvem noções de cidadania, aumento de autonomia e ampliação da rede de serviços e social (CAMBRAIA 1999). Em 1985, existiam 15 ambulatórios no Municipio de São Paulo, 7 na Região Metropolitana e 7 no interior do Estado, distribuídos de acordo com as divisões regionais da Coordenadoria de Saúde Comunitária (SES 1985).

Os outros niveis de atenção da rede de saúde deveriam atuar de forma complementar, de modo a criar uma rede de informações e intervenções adequadas aos níveis e/ou graus de comprometimento, evitando-se, assim, gastos e a mobilização de recursos desnecessários. Para a atenção básica, foram desenhadas equipes minimas de saúde mental, para as quais eram previstos pelo menos um médico psiquiatra, um psicólogo e um assistente social (IDEM; AMARAL 1997; SCARCELLI 1998).

Em 1987, a Secretaria de Estado da Saúde, já sob a gestão Quércia, passa por nova reorganização em sua estrutura básica: são criados novos Fóruns e Conselhos de saúde e outros órgãos colegiados: grupos de apoio técnico de planejamento e 5 Coordenações de Regiões de Saúde, sendo que à Coordenação 3 ficava atrelada a Coordenadoria de Saúde Mental, que fora extinta enquanto unidade da Secretaria de Saúde. A Coordenação de Regiões de Saúde 1 compreenderia 15 escritórios regionais de saúde (os ERSA's), que correspondiam à anteriores divisões regionais de saúde da Capital e Região Metropolitana e as demais coordenações dividir-se-iam entre os 44 
escritórios regionais, representantes das cidades e regiões do Interior. Nesta estrutura. as diretrizes e programas de saúde mental ficaram centralizadas no Assessor para Assuntos de Saúde Mental (SES 1987).

A partir de 1989, dá início o processo de reformas no Complexo Hospitalar do Juqueri, começando pela sua estrutura física, com o objetivo de preservação da memória arquitetônica e histórica deste que foi o "berço" das práticas psiquiátricas brasileiras (SES 1988-1993), para, em seguida, prosseguir às reformas administrativas de acordo com as novas diretrizes políticas (SÄ 1991; 1994).

A Assembléia Geral das Nações Unidas elege o ano de 1991 como sendo o marco para um novo olhar sobre os direitos dos doentes mentais à proteção e assistência e seu apelo se expressa pela Declaração dos Direitos dos Doentes Mentais, cujos princípios fundamentais se enunciavam:

1 - Não deverá existir discriminação em virtude de doenças mentais:

2 - Na medida do possivel. deve-se conceber a todo paciente o direito de ser tratado e atendido em sua própria comunidade;

3 - Todo paciente deverá ter o direito de ser tratado num ambiente o menos restritivo, com o tratamento menos restritivo ou intrusivo (ONU 1991).

E, em outubro de 1992, é instituida a Comissão Organizadora da $1^{\text {a }}$. Conferência Estadual de Saúde Mental do Estado de São Paulo, composta por representantes da Secretaria de Saúde, coordenações regionais e departamentos municipais de saúde; representantes de entidades de classe e do Movimento de Luta Antimanicomial; e representantes de entidades formadoras, de usuários e dos 
prestadores privados de serviços de saúde mental, e a pauta de discussões foi a reestruturação da atenção em saúde mental enquanto possibilidade de cidadania, tanto para os usuarios como para os profissionais, além das novas formas de financiamento e gestão em consonância com as diretrizes do SUS (SES 1992).

A despeito de nesse momento não terem ocorrido, no âmbito estadual, avanços no processo de municipalização e de implantação do Sistema Único de Saúde, destacou-se, na esfera da Secretaria de Saúde do Município de São Paulo, a implantação de uma rede de hospitais dia de leitos psiquiátricos em hospitais gerais e de unidades de Saúde Mental nos prontos-socorros já a partir de 1990, com a gestão de Luiza Erundina.

De acordo com a Secretaria Municipal de Saúde de São Paulo, esse modelo de assistência à saúde mental tem:

"caracteristicas multiprofissionais e é desenvolvido através de uma rede integrada. regionalizada e hierarquizada de serviços constituidos por: Postos de Assistência à Saúde - PAS - com equipes minimas em saúde mental (...): Hospitais Dia em Saúde Mental: unidades de cuidados ambulatoriais destinados a individuos com transtornos mentais graves em situação de crise. Modalidade aberta que evita a cronificação e preserva os vínculos sóciofamiliares dos individuos portadores de transtorno mental: Emergências psiquiátricas nos Prontos Socorros Municipais (...); Enfermarias psiquiátricas de curra permanência nos hospitais gerais municipais; Atendimento a casos agudos: psicoses endógenas e orgânicas: psicoses dissociativas; psicoses individuais e por tóxicos. Atendimento à individuos drogadependentes 
(...).Atendimento nos centros de convivência e cooperativas (...)" (SMS-SP 2001).

A proposta do tipo institucional Hospital Dia tem como principal objetivo o cuidado intensivo através de abordagens múltiplas: medicamentosa, psicoterápica, terapia ocupacional, orientação e apoio familiar, oficinas sócio-esportivas, podendo-se evitar, assim, a internação psiquiátrica hospitalar, propiciando o retorno do paciente à unidade de saúde para o acompanhamento terapêutico. Para realização de suas atividades, deve contar com equipe multiprofissional composta por psiquiatras, psicólogos, terapeutas ocupacionais, enfermeiros e assistente social (DIAS 1995).

Até 2001, o Município de São Paulo contava com 14 Ambulatórios de Saúde Mental, entre os quais, 2 Centros de Atenção Psicossocial, municipalizados no início dos anos 90 e 15 unidades de Hospital Dia em Saúde Mental, dos quais 3 infantis e 1 para crianças e adolescentes, além de equipes mínimas de saúde mental em algumas unidades básicas de saúde e leitos psiquiátricos em enfermarias de hospitais gerais. Nesta época, com a retomada do processo de municipalização da saúde, em nível estadual, além dos ambulatórios, era possivel encontrar equipes de saúde mental nas demais modalidades assistenciais, tais como os Núcleos de Gestão Assistencial, Ambulatórios de Especialidades, além de outros programas como os CRST's (Centros de Referência em Saúde do Trabalhador), os CRT DST/AIDS (Centros de Referência para o Tratamento de Doenças Sexualmente Transmissiveis e AIDS), que atualmente integram a rede municipalizada de serviços de saúde mental. 
Com a municipalização em curso no Municipio de São Paulo, deflagrada no início de 90 pela gestão Luiza Erundina, interrompida pelas gestões de Paulo Maluf e Celso Pitta ${ }^{10}$ e retomada em 2001, a configuração dos equipamentos de saúde e de saúde mental, em particular, sofreram, ainda, mudanças e transformações.

A exemplo dos CAPS Itapeva e Perdizes, os demais ambulatórios de saúde mental também foram municipalizados, sendo que alguns desses, a partir de final de 2002, passaram para a modalidade hospital dia e outros para CAPS I e II, expressando formas diferenciadas de financiamento pelo SUS, ao mesmo tempo em que alguns hospitais dia adulto passaram a atender adolescentes.

\footnotetext{
${ }^{10}$ Paulo Maluf e Celso Pitta estiveram à frente do governo municipal paulista entre os anos de $1993 \mathrm{e}$ 2000. Propuseram para o setor saúde um novo sistema de financiamento e gestão: o PAS - Plano de Atendimento à Saúde, cujas ações não contemplavam os niveis de promoção e prevenção, voltandose para o pronto atendimento e encamirhamento hospitalar. Administrativamente, a cidade foi dividida em 13 cooperativas, correspondendo a 13 núcleos de atendimento, constituídas por protissionais da rede que estavam de acordo com as diretrizes do PAS e, também por outros, designados para compor as diretorias. Aqueles profissionais que não aderiram ao sistema cooperativado, foram transferidos para outras Secretarias. A esse respeito, ver: SÁ et. al. (1997). Quanto ao financiamento, os recursos do Tesouro Municipal eram repassados para as cooperativas em um montante proporcional à demanda de cada região, correspondente às cooperativas e aos "módulos" de atendimento que prestavam. Tais recursos eram antecipados e as cooperativas garantiam dinheiro em caixa antes mesmo de realizarem os atendimentos, não havendo nenhum mecanismo técnico de controle desse fluxo. Além disso, foram extintos os Conselhos Distritais de Saúde. Alguns estudiosos consideram o PAS uma versão preliminar de um projeto maior de privatização do sistema de saúde, cujas propostas se opõem aos princípios do SUS, portanto, revelando um caráter inconstitucional. Ver: PMSP (1995); COHN e ELIAS (1998).
} 


\subsection{Perspectivas de saúde (mental) para os anos 2000}

Segundo o IBGE (2000), existiam nessa época cerca de 169.872 .859 de pessoas residentes no Brasil, das quais $\mathbf{3 7 . 0 3 5 . 4 5 6}$ pertenciam ao Estado de São Paulo, a unidade da federação mais populosa, correspondendo a $21,8 \%$ do total de habitantes. Entre estes, 10.398.576 concentravam-se no município de São Paulo, sendo que $52 \%$ destes eram do sexo feminino, o que corrobora a tendência estadual geral, em que 50,8\% dos indivíduos também são do sexo feminino.

Para esse mesmo ano, as unidades de saúde ambulatoriais do Estado contratadas e conveniadas com o Sistema Único de Saúde distribuiam-se da seguinte forma (Tabela 1): 


\begin{tabular}{|c|c|c|c|c|}
\hline Unidades de Asúde & ESP & RMSP & MSP & Total \\
\hline Posto de Saúde & 428 & 26 & 1 & 455 \\
\hline Unidade Básica de Saúde & 2234 & 533 & 199 & 2966 \\
\hline Unidade de Saúde da Familia & 348 & 52 & 25 & 425 \\
\hline Policlínica & 264 & 47 & 12 & 323 \\
\hline Ambulatório de Unidade Hospitalar & 568 & 115 & 53 & 736 \\
\hline Unidade Mista de Saúde & 106 & 29 & 2 & 137 \\
\hline Pronto-Socorro & 113 & 22 & 2 & 137 \\
\hline $\begin{array}{l}\text { Consultório } \\
\text { Unidade Ambulatorial }\end{array}$ & 142 & 8 & 1 & 151 \\
\hline Especialidade* & 488 & 148 & 69 & 705 \\
\hline Centro de Reabilitação & 114 & 13 & 1 & 128 \\
\hline $\begin{array}{l}\text { Unidade Serviço de Apoio a } \\
\text { Diagnose e Terapia }\end{array}$ & 492 & 118 & 71 & 681 \\
\hline Unidade Móvel & 51 & 9 & -- & 60 \\
\hline Unidade Móvel Emergência & 54 & 15 & 2 & 71 \\
\hline
\end{tabular}

Fonte: Ministério da Saúde (2001a); Fundação SEADE (2003).

* Entre os quais, os ambulatórios de saúde mental.

É possivel observar que a rede ambulatorial apresentou, no periodo de 19992000, relativa ampliação no número de unidades vinculadas ao Sistema Único de Saúde - SUS, nos três segmentos prestadores: público (3\%), privado (5\%) e universitário (13\%), destacando-se em todos o crescimento dos serviços de apoio e diagnose e terapêutico. Entre as unidades que prestam serviços médico- 
odontológicos, destaca-se o incremento das Unidades de Saúde da Familia (134\%), resultado do avanço na implantação do Programa de Saúde da Família (PSF), especialmente no interior do Estado".

Segundo dados do Ministério da Saúde (2001a), em 2000, o SUS realizou cerca de 395 milhões de procedimentos ambulatoriais no Estado de São Paulo, englobando diferentes graus de complexidade, como consulta médica, cirurgia ambulatorial, radiodiagnóstico e quimioterapia. Desse total, $52 \%$ dos atendimentos são classificados como de atenção básica, $40 \%$ de média complexidade e $8 \%$ de alta complexidade, majoritariamente prestados pelo setor público, porém com participação diferente por nivel de complexidade. $O$ setor público responde quase que integralmente pela atenção básica $(96 \%)$ e pela maior parte dos procedimentos de média (52\%) e alta complexidade (62\%). A participação do setor privado mais relevante ocorre nos procedimentos de média complexidade (31\%) e a do prestador universitário, os de alta complexidade (24\%),

$\mathrm{Na}$ rede hospitalar, confirmou-se a tendência de anos anteriores, com estabilidade total de leitos, discreto acréscimo na rede municipal $(1,5 \%)$ e filantrópica $(2,7 \%)$ e queda entre os contratados $(8 \%)$. Em sentido inverso ao panorama de nãoampliação da rede hospitalar, houve aumento de leitos na Região Administrativa de São José dos Campos (13\%) e Região Metropolitana da Baixada Santista (6\%). Foram realizadas 2,2 milhões de internações pelo SUS, valor ligeiramente superior a 1999, tendo um pouco mais da metade ocorrido em hospitais filantrópicos. Observase aumento nas internações de clínica médica (6\%), pediatria (3\%) e tisiologia (7\%).

${ }^{11}$ O PSF é uma estratégia que proriza as ações de promoção, proteção e recuperação da saúde dos indivíduos e da familia e está estruturado a partir de uma unidade de saúde pública, com equipe 
As internações em clínica obstétrica cairam 5\%, em relação a 1999 , fenômeno que ocorreu sistematicamente ao longo dos anos 90 , como resultado da diminuição no numero de partos. Apesar da queda, as internações por gravidez, parto e puerpério ainda representam o principal grupo de causas da internações das mulheres (38\%)

Durante a última década, tem se observado uma reorganização na distribuição das especialidades, com ampliação dos leitos de clínicas básicas - cirúrgica, obstétrica, médica e pediátrica. Em contrapartida, em 2000 , observou-se a diminuição de $4 \%$ nos leitos de psiquiatria, de acordo com a mudança do modelo assistencial, de desospitalização da atenção psiquiátrica Apesar de representar uma parcela pequena das internações (4.200), destaca-se o significativo aumento de $40 \%$ nas internações de psiquiatria em hospital dia (MS 2001a).

Cabe lembrar que, mesmo frente a esses números que expressam certo aumento do atendimento à saúde, e conseqüente aumento da cobertura pelo sistema, ainda há um contingente substancial de individuos sem acesso à atenção primária ou, que recebem um primeiro atendimento mas que não são acompanhados em outros niveis de atenção.

O aumento e diversificação da força de trabalho em saúde, por sua vez, é fenômeno presente desde meados da década de 30 , no entanto, com caracteristicas diferentes nos últimos anos, quando o crescimento do número de médicos perde destaque para outras categorias. No periodo 1999-2000 destaca-se o aumento de fisioterapeutas (52\%), de técnicos (30\%) e auxiliares de enfermagem (14\%), resultado de políticas e programas nacionais de formação e capacitação do pessoal de 
enfermagem Quanto à composição, as categorias de médico e auxiliar de enfermagem mantêm os maiores contingentes, com 75 mil e 153 mil profissionais, respectivamente. O Estado de São Paulo apresenta o coeficiente de 2,0 médicos por mil habitantes, mas existem desigualdades na sua distribuição regional ${ }^{12}$.

Os repasses do Ministério da Saúde para São Paulo e seus municípios, no âmbito do SUS, tiveram crescimento de $11 \%$ no periodo $1999-2000$, atingindo R\$ 3,1 bilhões. A modalidade de pagamento que mais cresceu foram os repasses realizados fundo a fundo, do Ministério da Saúde diretamente para as prefeituras e o Estado, subdivididos em transferências para assistência de alta e média complexidade, com crescimento de 13\%, e assistência de atenção básica, $31 \%$. Esse fenômeno é decorrente das mudanças implementadas a partir de 1998, que vêm substituindo gradativamente o pagamento por prestação de serviços, realizado pelo Ministério, pelo repasse de valores globais aos Municipios e Estados para que façam a alocação dos recursos para atenção básica e o pagamento dos prestadores de serviços de alta e média complexidade, sob sua gestão.

Do montante de recursos destinados às internações hospitalares, $83 \%$ foram destinados às que ocorreram em leitos de clinicas básicas e destes, a maior parcela é da especialidade de cirurgia; entre os gastos por grupos de doenças, destacam-se as doenças do aparelho circulatório como as de maior despesa (19\%), seguida, sucessivamente, pelas internações cujas causas classificam-se entre os transtornos

\footnotetext{
12 Há regiões com altas concentrações, como a Região Administrativa de Ribeirão Preto $(3,1)$ e Região Metropolitana de Campinas $(2,5)$, e outras com valores bem abaixo da média estadual, como as Regiơes Administrativas de Araçatuba $(1,1)$ e de Registro $(0,7)$. Os auxiliares de enfermagem, com coeficiente de 4,1 por mil habitantes, também apresentam concentraçăo em algumas regiões, com destaque para as Regiỗes Metropolitanas de São Paulo $(4,9)$ e de Santos $(4,4)$ e Região Administrativa de Marília $(4,5)$ (Fundação SEADE Op. Cit.).
} 
mentais e comportamentais (12\%) e gravidez, parto e puerpério (10\%) (MS Op. Cit.; Fundação SEADE 2003).

A partir de 2001, no município de São Paulo, com o "desmonte" do PAS, hoúve a criação de 41 distritos sanitários, reagrupados em 39 no ano seguinte em função das subprefeituras paulistanas instituídas como parte concreta da municipalização. Ainda em 2002, foram implantadas as 31 coordenadorias de saúde, o que cọrrespondeu à quarta reorganização do setor, no governo Marta Suplicy.

Essa nova mudança estrutural engendrou uma crise organizacional e política, caracterizada pela indefinição das funções dos diretores de distritos e coordenadores e foi acirrada pelo debate sobre a filiação política desses últimos (LEITE 2003).

No dia 09 de abril de 2001 foi comemorado o Dia Mundial da Saúde 2001 e o tema central foi "Cuidar sim, Excluir não", uma alusão à necessidade de inclusão e aceitação das pessoas com transtomos mentais. A OMS - Organização Mundial da Saúde - em seu relatório sobre as condições de saúde no mundo declara:

"a saúde mental - negligenciada por demasiado tempo - é essencial para o bem-estar geral das pessoas, das sociedades e dos paises, e deve ser universalmente encarada sob uma nova luz" (OMS 2001:13).

Nesse relatório, intitulado "Nova Concepção, Nova Esperança", o foco central em torno do qual se discutem as diretrizes atuais para este campo, preconizase que a saúde mental não pode e não deve ser considerada em separado da saúde fisica, sob pena de não ser possível um avanço significativo dessa discussão, pois já é sabido que o exame criterioso da relação entre os fatores biológicos (genéticos) e 
sociais (ambientais) que atuam na psiquê pode ser a chave para a compreensão das causas das doenças da mente e do cérebro. Nesse sentido, falar em saúde mental significa falar em comportamento saudável, e neste, necessariamente, estão implicados aspectos da saúde mental. Outra correlação importante está entre saúde mental e pobreza. Sem dúvida, sobretudo em paises desiguais, como é o caso do Brasil, é entre a população carente que prevalece o maior indice de transtomos mentais, inclusive o abuso de substâncias químicas (drogas e álcool), pois a maior parte dessas pessoas ainda hoje não tem acesso a tratamento.

Desta forma, o desnivel de tratamento é um dos mais importantes problemas e desafios para as políticas de saúde mental de hoje. Esses transtornos acometem cerca de 20 a $25 \%$ do total de pessoas em todo o mundo, em dado momento da vida. Projeta-se que até 2020, a carga dessas doenças terá mais $15 \%$. E, no entanto, somente uma pequena minoria das pessoas atualmente afetadas recebe qualquer tratamento.

Os transtornos mentais mais comuns, cujo grau de incapacidade é alto, têm um forte impacto sobre a qualidade de vida das sociedades. São eles: os transtornos depressivos, a esquizofrenia, os resultantes do abuso de substâncias, a epilepsia, o retardo mental, os transtornos da infância e da adolescência e a doença de Alzheimer. A epilepsia, embora seja um distúrbio claramente neurológico, é incluída por ter sido historicamente encarada como doença mental e ser ainda considerada como tal em muitas sociedades. Assim como os portadores de transtornos mentais, os epiléticos são estigmatizados e sofrem também incapacidade grave quando não tratados. 
Este item do Relatório examina, ainda, a associação entre tais transtomos e a possibilidade de suicídio, que assume relativa importância para a saúde pública. Considerada a primeira causa de morte entre jovens em paises desenvolvidos, vem crescendo também entre jovens de paises em desenvolvimento e entre mulheres, passando recentemente a constituir um crescente problema, devendo-se ser pensadas formas institucionais de prevenção.

Neste sentido, propõe: 1) A transferência positiva dos hospitais ou instituições do tipo carcerário para a atenção na comunidade, com apoio na disponibilidade de leitos para casos agudos nos hospitais gerais - proposta identificada já nos anos 80 , em São Paulo, e não implementada por conta da não efetivação do sistema local de saúde (SILOS); 2) O reestabelecimento dos princípios fundamentais que devem nortear a atenção em saúde mental em qualquer sociedade: o diagnóstico adequado, se possivel precoce, a intervenção precoce, o uso racional de técnicas de tratamento, a continuidade da atenção e uma variedade de serviços, além dos chamados princípios adicionais, tais como: a participação dos usuários, através das associações de familiares, o envolvimento da comunidade local e a integração com a atenção básica de saúde. Tudo isso dentro da triade básica que tem configurado o modelo contemporâneo de atenção em saúde mental, a saber: medicação, psicoterapia e reabilitação psicossocial.

Quanto às políticas de saúde mental e a provisão de serviços, o Relatório recomenda:

"a fixação de prioridades entre necessidades de saúde mental. condições. serviços, tratamentos e estratégias de prevenção e promoção. bem como 
escolhas a serem feitas em relação ao seu financiamento. $\dot{E}$ preciso que os serviços e as estratégias de saude mental sejam bem coordenados tanto entre si como com outros serviços. tais como seguridade social, educação, (...) que os governos. como gestores finais da saude mental, assumam a responsabilidade por assegurar que essas complexas atividades sejam levadas a cabo. Uma função crítica dessa gestão é a formulação e implementação de politicas" (IDEM: 22).

Ressalta, ainda, a necessidade de se reverem as opções de financiamento para a prestação de serviços em saúde mental, que não devem ser diferentes das dos serviços de saúde em geral, e de priorizar os grupos vulneráveis em saúde mental, quais sejam: crianças e adolescentes, idosos, mulheres vitimas de abuso, pessoas deslocadas de sua terra natal e dependentes químicos, para os quais as formulações e diretrizes aparecem em separado.

A Assembléia Mundial da Saúde 2001 discutiu a saúde mental em todas as suas dimensões, destacando a persistente insuficiência dos serviços que impedem milhões de pessoas em todo o mundo de receberem o tratamento de que necessitam e a que têm direito. Nesta direção, no decorrer de todo o ano de 2001, os Estados Membros da ONU - Organização das Nações Unidas - fizeram notar a luta pela manutenção e ampliação dos direitos dos doentes mentais, 10 anos depois de sua Declaração, apoiando a organização e o lançamento, por exemplo, de campanhas globais sobre o controle da depressão e prevenção do suicídio, da esquizofrenia e da epilepsia. 
No caso brasileiro, tal movimento se expressou pela realização de Conferências Estaduais de Saúde Mental em todo o pais, ao longo do mês de novembro de 2001, em que foram discutidas e votadas as propostas para as diretrizes naçionais para a saúde mental e estratégias de implementação destas em niveis locais; foram também escolhidos os delegados para a participação na $3^{\mathbf{2}}$. Conferência Nacional de Saúde Mental, realizada em dezembro, no Distrito Federal, Brasília.

No Estado de São Paulo, realizaram-se, entre 16 e 18 de novembro de 2001, a $3^{\mathrm{a}}$. Conferência Estadual de Saúde, a $2^{\mathrm{a}}$. Conferência Estadual de Saúde Mental e $1^{\mathrm{a}}$. Conferência Estadual de Vigilância Sanitária. Essas Conferências contaram com 2.500 delegados e as discussões específicas com a presença de 800 delegados nas plenárias, as quais elegeram os representantes de 70 Municipios do Estado de São Paulo para a Conferência Nacional de Saúde Mental. O processo das Conferências Regionais possibilitou que mais de 400 Municípios pudessem comparecer e discutir a reorientação do modelo de atenção em saúde mental, e criou a necessidade de cada um dos Municipios organizar sua própria Conferência, pois a diversidade de suas realidades e condições implica, em alguns casos, estabelecer ligações intermunicipais para garantir para seus usuários acesso aos serviços substitutivos como alternativa à internação integral.

O Relatório final da $2^{2}$. Conferência Estadual de Saúde Mental de São Paulo propôs, para o desenvolvimento de politicas municipais de saúde mental no âmbito do Sistema Único de Saúde, que sejam consideradas as necessidades especificas e o perfil epidemiológico de cada região, articulando os diversos niveis e modalidades de assistência e reformulando a atenção básica, associada às ações do Programa de 
Saúde da Familia, no que diz respeito à prevenção e promoção da saúde mental, bem como sensibilizando-a quanto ao diagnóstico e detecção precoce e, ainda,

"implementando uma rede de serviços territoriais de saude mental substitutivos ao hospital psiquiátrico, integrada, sob orientação única. composta por: emergência psiquiátrica. leito psiquiátrico em hospital geral. centro ou núcleo de atenção psicossocial. núcleo de atenção à dependência às drogas e alcoolismo, hospital dia. oficina terapêutica. centro de convivência $e$ cooperativa, cooperativa de trabalho, serviço residencial terapêutico, que trabalhem de forma integrada e complementar" (MS 2001b).

Ainda em relação às politicas municipais de saúde mental, o Relatório sugere que se desenvolvam ações intersetoriais, envolvendo os técnicos e tecnologias de todas as Secretarias e se estabeleçam parcerias com Universidades e ONG's Organizações Não Governamentais -, sobretudo quando tais ações forem direcionadas à crianças e adolescentes com transtornos mentais ou mesmo vítimas de violência doméstica.

Além do fortalecimento das ações de saủde mental na atenção básica, é necessário a melhoria real da qualidade dos serviços de urgência e emergência psiquiátrica (DEL-BEM et. al. 1999; SANTOS et. al. 2000; SEIBELL 2002) para que aconteça o redimensionamento desejado nas internações psiquiátricas rumo à desinstitucionalização, que contribua com a implementação de outros serviços substitutivos, tais como as residências terapêuticas, e para isso é preciso que se estabeleçam mecanismos de controle para a utilização dos medicamentos que 
constituem o Programa de Dispensação de Medicamentos de Saúde Mental, através da farmacovigilância e da instituição de protocolos padrão na administração de tais medicamentos ${ }^{13}$

No que se refere às propostas votadas pelos participantes da $3^{\mathbf{a}}$. Conferència, para a consolidação das politicas de recursos humanos em saúde mental, estas requerem o estabelecimento de uma política de recursos humanos (municipal, estadual e federal) voltada para a capacitação sistemática e qualificação continuada de seus trabalhadores, por meio de convênios com Universidades e com outras instâncias de governo, e também de supervisão técnica e institucional permanente; a melhoria das condições de trabalho e remuneração, com adequação salarial, equiparação de carga horária e acompanhamento da saúde mental desses trabalhadores; o estabelecimento de planos de carreira; a democratização e compartilhação dos niveis gestores para que seja possivel garantir que os recursos públicos, das esferas estaduais e federais, sejam repassados adequadamente e que linhas de financiamento e subsídios sejam criadas e aplicadas corretamente para a efetivação da Reforma Psiquiátrica no Brasil.

Neste sentido, este resgate histórico da constituição das práticas de saúde, em São Paulo, possibilitou uma aproximação das condições politicas e socio-econômicas que nortearam a concepção e instituição das diretrizes nacionais para o setor saúde, revelando os diversos cenários e ideologias em que se inscreveram as politicas de

\footnotetext{
:3 A discussão em torno da política de medicamentos brasileira é antiga e suas diretrizes têm sido objeto de muitas controversas. Nos últimos tempos, a distribuição do coquetel para os pacientes com ADS e a implementação dos Genéricos, de certa forma, colocou em debate os atuais impasses por que passam tais políticas e, também, as dificuldades que enfrentam frente à indústria farmacêutica estrangeira. No que se refere aos psicofármacos, o Ministério da Saúde lançou em 1983 um Manual de orientação para a administração e uso destes medicamentos. In: LOBATO et. al. (1983).
} 
saúde mental, com destaque para os anos 80. Permitiu, assim, localizar a problemática deste estudo: a relação recíproca entre o processo de especialização do trabalho em saúde e o novo modelo de assistência à saúde mental.

\subsection{Objetivos}

Este estudo teve por objetivos:

1 - Caracterizar o trabalhador coletivo de saúde mental dos serviços substitutivos da rede pública de saúde do Municipio de São Paulo, nas modalidades ambulatorial e hospital dia, por meio de um levantamento das atuais inserções no trabalho e situações ocupacionais.

2 - Realizar um estudo acerca das representações que norteiam o exercício profissional e a prestação da assistência em saúde mental, para que seja possível compreender as referências, valores e saberes que os orientam e, também, a relação entre estes e as condutas e práticas cotidianas, individuais e coletivas, voltadas para o cuidado e tratamento do sofrimento psíquico bem como para a inclusão social destas pessoas. 


\section{2 \\ Metodologia}

Nietzsche.

$O$ abismo é uma lacuna, uma fenda infinita na realidade. Se chegarmos a notá-lo, ele pode se abrir debaixo de nós. Devemos nos afastar dele ou enfrentá-lo sem rodeios. Sou muito tenaz, para o bem e para o mal. Quando minha atenção é atraida, não consigo desviá-la. Isso pode ser uma grande força ou uma grande fraqueza. Faz de mim um investigador. Faz-me obsessivo. Fez de mim. neste caso, um explorador do abismo.

Oliver Sacks, Com uma perna só 
O propósito deste capítulo é descrever os procedimentos metodológicos adotados pela pesquisa bem como enunciar os referenciais teóricos assumidos. A opção pela metodologia quanti-qualitativa se deu em função da própria natureza do fenômeno estudado e pela necessidade de conhecer o grupo pesquisado, caracterizado por certo grau de especialização, no que se refere às variáveis clássicas do campo dos Recursos Humanos em Saúde, tais como: categoria profissional, jornada de trabalho, vínculo empregaticio, entre outras, que freqüentemente são utilizadas pelos estudos sobre o trabalho em saúde.

Os trabalhos de campo foram desenvolvidos em duas etapas: na primeira, foi preenchido um formulário (ANEXO 1) contendo questões fechadas que foram analisadas estatisticamente, propiciando uma primeira aproximação ao objeto; na segunda, foram gravadas entrevistas em profundidade a partir de roteiro temático (ANEXO 2), com profissionais que compõem a equipe do Hospital Dia Infantil em Saúde Mental da Moóca, que se disponibilizaram a participar da pesquisa. 


\subsection{Procedimentos Metodológicos}

\subsubsection{Levantamento quantitativo: a primeira fase do trabalho de campo}

Talvez seja possível nomear o primeiro momento do percurso da pesquisa de campo como sendo o da "busca", uma vez que se refere ao momento dos últimos acertos acerca de onde iniciar e quem considerar na investigação. Nesse momento, permeado de anseios e angústias, identifica-se uma experiência comum a todo pesquisador, que corresponde a uma situação muito bem descrita por DA MATTA (1981). Em seu texto, em que identifica "os medos" do pesquisador como fruto do seu desconhecimento do "outro", o autor mostra que essa situação é inteiramente reversível, já que, aos olhos desse "outro", também nós somos "estranhos". Assim, coloca-se para o investigador o desafio de transformar o "estranho" em "familiar", como tarefa fundamental do trabalho de pesquisa. Esta situação, por sua vez, tem também um avesso simétrico, que deve aplicar-se a este caso: é necessário "transformar o familiar em exótico".

Esta primeira fase da pesquisa de campo correspondeu ao levantamento dos dados de natureza quantitativa, coletados junto aos serviços de saúde mental do município de São Paulo, nas modalidades ambulatorial e hospital dia, na ocasião ainda divididos entre municipais e estaduais: outubro de 2001 e setembro de 2002.

Um primeiro recorte, no tocante às modalidades assistenciais consideradas, se deu em função da própria natureza dos objetivos de cada uma e dos papéis políticos 
que assumiram nos últimos 20 anos, de mudança do modelo psiquiátrico, a partir dos quais é possivel pensar não apenas o impacto que tiveram sobre o conteúdo do trabalho e, portanto, da assistência prestada aos que sofrem de transtornos mentais, mas também sobre os próprios profissionais, que tiveram suas condições de trabalho alteradas em função de tais mudanças.

Outro recorte diz respeito ao fato de a investigação privilegiar os profissionais de nịvel universitário. Embora profissionais de nível médio e operacional representassem importante papel tanto na composição da força de trabalho em saúde como no próprio exercício cotidiano do trabalho, sobretudo em saúde mental, como foi possivel constatar por ocasião das visitas aos serviços e pelas entrevistas, estes não foram incluidos diretamente, dada a variedade de atribuições e funções assumidas por esses agentes, fragmentadas ainda mais pela terceirização ou justapostas, pela municipalização da prestação da assistência mas não da administração dos recursos humanos.

Desta forma, o primeiro passo foi levantar, junto às respectivas coordenadorias de saúde mental, as listagens de equipamentos, contendo nome dos estabelecimentos, endereços e telefones. Para tanto, dirigi-me aos então coordenadores dos programas para efetuar os procedimentos legais e éticos de solicitação e consentimento para a realização da pesquisa. Apresentei-Ihes carta de solicitação (ANEXO 3) para que eu pudesse visitar os serviços e proceder aos levantamentos dos dados, e formulário da Comissão Nacional de Ética em Pesquisa CONEP (ANEXO 4) para serem por eles preenchidos e assinados, como forma de permissão de meu acesso aos serviços, que foram, posteriormente, encaminhados 
junto ao projeto de pesquisa para o Comitê de Ética em Pesquisa da Faculdade de Saúde Pública da USP para apreciação (ANEXO 5).

A partir daí, esboçou-se a distribuição dos Ambulatórios de Saúde Mental, Centros de Atenção Psicossocial e dos Hospitais Dia em Saúde Mental, segundo as grandes regiões do Município e Distritos de Saúde (Quadro 1; Figura 1):

Quadro 1. Distribuiçäo dos Serviços Substitutivos de Saúde Mental, segundo as zonas, os distritos de saúde e as modalidades

Município de São Paulo, 2001

\begin{tabular}{|c|c|c|c|c|c|}
\hline \multirow[t]{2}{*}{ Zonas } & \multirow[t]{2}{*}{$\begin{array}{l}\text { Distritos de } \\
\text { Saúde } \\
\end{array}$} & \multicolumn{3}{|c|}{ Modalidades } & \multirow[t]{2}{*}{ Total } \\
\hline & & ASM* & HD** & CAPS*** & \\
\hline \multirow[t]{7}{*}{ Leste } & Ermelino Matarazzo & - & $\mathrm{x}$ & - & 1 \\
\hline & Itaquera & $\mathrm{x}$ & $x$ & - & 2 \\
\hline & Moóca (Belenzinho e Móoca) & $\mathbf{x}$ & $x$ & - & 2 \\
\hline & São Mateus & $x$ & $\mathbf{x}$ & - & 2 \\
\hline & São Miguel Paulista & $\mathrm{x}^{1}$ & $\mathbf{x}$ & - & 2 \\
\hline & Vila Matilde & $\mathrm{x}$ & - & - & 1 \\
\hline & Vila Prudente & - & $\mathbf{x x}$ & - & 2 \\
\hline \multirow[t]{4}{*}{ Sul } & Capão Redondo (Jd. Lídia) & - & $\mathbf{x}$ & - & 1 \\
\hline & Jabaquara (Vila Guarani e Jabaquara) & $\mathrm{x}$ & $\mathbf{x}$ & - & 2 \\
\hline & Pinheiros (Itaim Bibi) & - & $\mathbf{x}$ & - & 1 \\
\hline & $\begin{array}{c}\text { Santo Amaro (Sto. Amaro, Sto. Amaro } \\
\text { e Largo 13) }\end{array}$ & $\mathbf{x}$ & $\mathrm{xx}^{1}$ & - & 3 \\
\hline \multirow[t]{4}{*}{ Norte } & Jaçanã & $\mathrm{x}$ & - & - & 1 \\
\hline & Pirituba & $\mathrm{x}$ & $\mathbf{x}$ & - & 2 \\
\hline & Tremembé (Mandaqui e Santana) & $\mathbf{x}$ & $\mathbf{x}$ & - & 2 \\
\hline & Vila Brasilândia & $\mathrm{x}$ & - & - & 1 \\
\hline \multirow[t]{2}{*}{ Oeste } & Butantã & - & $x$ & - & 1 \\
\hline & Lapa (Lapa e Perdizes) & $x$ & - & $\mathrm{x}$ & 2 \\
\hline Centro & $S e ́$ (Itapeva) & - & - & $\mathrm{x}$ & 1 \\
\hline \multicolumn{2}{|c|}{ Total } & 12 & 15 & 2 & 29 \\
\hline
\end{tabular}

* Ambulatório de Saúde Mental

** Hospital Dia

*** Centro de Atenção Psicossocial

10 ASM (São Miguel Paulista) e o HD (Largo 13) não se dispuseram a participar da pesquisa

Fonte: Secretaria Municipal de Saúde, 2001 e Secretaria Estadual de Saúde, 2001

Concepção e Elaboração: Silvana Maria de Souza 
Distribuição dos Serviços Substitutivos de Saúde, segundo os distritos e as modalidades

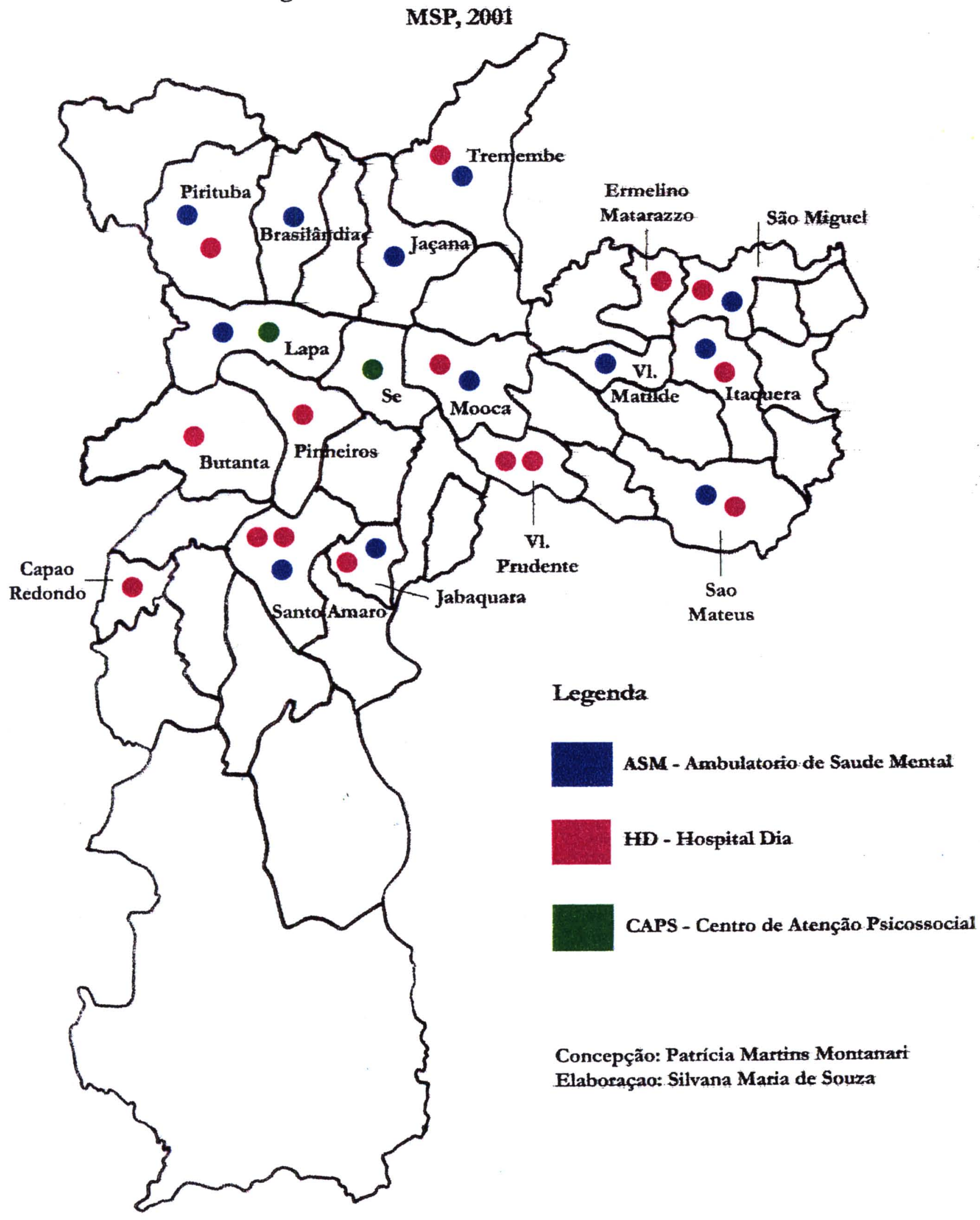


Esta fase se estendeu por um ano devido a dificuldades operacionais e de acesso aos serviços, pois a estratégia privilegiada de captação dos dados foi a de coletá-los diretamente nos serviços e pessoalmente. Ao mesmo tempo, os serviços estavam (estão) se reestruturando, o que significou ter que voltar pelo menos três vezes a alguns serviços para checar e/ou completar as informações fornecidas anteriormente.

De acordo com os objetivos do presente trabalho para a primeira fase da pesquisa de campo, foi realizado o mapeamento dos diversos profissionais - nível universitário e técnico - incorporados pelos 27 serviços pesquisados, envolvidos diretamente na prestação da assistência. Os dados foram obtidos junto aos diretores, chefias e/ou responsável administrativo pelos serviços, em principio sem horário marcado e em seguida com agendamento prévio. A primeira estratégia, inicialmente, pareceu mais eficiente, pois dispensava a adequação de horários e facilitava a utilização do veículo da Faculdade, que esteve à disposição da pesquisa, nesta fase, dois periodos por semana, durante dois meses. Tal estratégia, entretanto, mostrou-se inadequada, pois embora, de maneira geral, eu e minha pesquisa fôssemos bem recebidos pelos profissionais, muitos não tinham disponibilidade naquele momento, alguns não dispunham de todas as informações solicitadas, em alguns casos, os endereços estavam desatualizados e em um serviço, pelo volume de pacientes e após três visitas sem conseguir os dados, eu desisti. Assim, passei aos contatos telefônicos para agendar minhas próximas visitas e destes recebi uma negativa.

Foi preenchido um formulário para cada estabelecimento, elaborado com base em um já utilizado em pesquisa acerca de equipes mutiprofissionais e recursos 
humanos em saúde ${ }^{1}$, portanto devidamente validado e testado, contendo as seguintes variáveis de interesse:

a) para cada profissional de nível universitário -

Categoria profissional: correspondendo à profissão de saúde e/ou formação necessária.

Cargo: para os diretores das unidades ou chefias técnicas, quando referidas espontaneamente.

Idade atual: idade no momento da entrevista, em anos completos.

Sexo: masculino ou feminino.

Jornada de trabalho: número de horas trabalhadas, em horas semanais.

Tipo de vínculo empregatício: referindo-se ao tipo de inserção e condição de trabalho no momento da entrevista.

Tempo de trabalho na unidade: tempo de trabalho no atual serviço, em anos completos.

Tempo de trabalho no serviço público: considerando-se todos os vínculos anteriores na área da saúde pública.

Área de especialização: referindo-se à continuidade da formação dos profissionais, tanto acadêmica como institucional.

\footnotetext{
${ }^{1}$ Refere-se a pesquisa coordenada por Schraiber e Peduzzi (Op. Cit.) sobre recursos humanos em saúde e equipe multiprofissional, da qual fui pesquisadora de campo entre 1996 e 1997.
} 
b) para os profissionais de nivel médio: o número total destes profissionais, por categoria ocupacional, que neste caso correspondeu às diversas nomenclaturas referentes aos cargos.

Estes dados foram tabulados e digitados em software compativel à natureza desses dados (EPIINFO, versão 6.0), e à medida que eram coletados iam compondo os bancos de dados, que coloco à disposição das Secretarias de Saúde. Tais informações receberam um tratamento estatístico, descritivo, para que pudessem revelar padrões e tendências que favorecessem a reflexão sobre a conformação das equipes nos modelos assistenciais considerados e a especificidade do trabalho em saúde mental.

\subsubsection{Levantamento qualitativo: a segunda fase do trabalho de campo}

O oficio de pesquisador, precisamente daqueles inseridos em campos interdisciplinares, como é o caso dos cientistas sociais na saúde pública, facilita e coloca em perspectiva aspectos mais subjetivos das vivências, tanto para quem pesquisa como para "os pesquisados", pois quando se trata de homens com sentimentos, sonhos e história, não é possivel passar por cima das subjetividades. Esse movimento convoca-nos a refletir sobre a necessidade de aprender a respeitar e compreender o outro como condição mesma para entender a si próprio, como ser humano na condição de pesquisador. DA MATTA (1975) ensina que a relação que se estabelece entre "nós" e os "outros", procurando construir uma ponte entre 
universos de significações diferentes "depende essencialmente de humores. temperamentos. fobias e todos os outros ingredientes das pessoas e do contato humano" (DA MATTA 1975; p. 19).

Com a finalização da primeira fase, após esse "contato" que estabeleci com os serviços visitados e seus profissionais, ficou clara a necessidade de aprofundamento de algumas questões que se anunciaram com a primeira leitura dos dados quantitativos. A partir, portanto, da caracterizaçăo da inserção concreta dos agentes do trabalho e da aproximação com as configurações dos trabalhos em saúde mental, foi possivel considerar as equipes mais completas em termos de sua diversidade e atuação profissional para esta segunda fase da pesquisa.

Nesta fase, a abordagem qualitativa das narrativas buscou apreender 0 cotidiano das práticas e o sentido e significados do trabalho ${ }^{2}$ em saúde mental para esses profissionais e captar as especificidades e diferenciais das percepções, segundo os diversos tipos de formação profissional (TRIVIÑOS 1992; SPINK 1997).

Foram realizadas, para tanto, entrevistas em profundidade a partir de um roteiro temático, sem, contudo, pretender-se criar uma estrutura rígida de questões que, por sua vez, sofreu certa variação em função do profissional entrevistado. $O$ roteiro, neste aspecto, facilitou as "situações de entrevistas" e em nenhum momento cerceou os entrevistados ou a mim, entrevistadora. A elaboração do roteiro, motivada pela diversidade de situações que poderia se apresentar, contemplou aspectos mais gerais relativos às trajetórias de formação e profissional, considerando que cada individuo traria sua experiência pessoal que, ao final, ligar-se-iam. Desta forma, foram 
incentivadas narrativas mais livres, minimizando o risco de indução a padrões de respostas, favorecida pela relação dialógica que caracterizou todas as entrevistas (KIDDER 1987).

No processo de reelaboração do roteiro, os principais temas que deveriam ser abordados foram: a qualificação técnica e especializações do trabalho em saúde; a significação das atividades desenvolvidas individualmente e dos saberes que as fundamẹtam: a concepção acerca da colaboração no desenvolvimento das atividades. e, ainda, houve espaço para comentários e sugestões quanto ao próprio roteiro, por exemplo, e sobre demais aspectos considerados por eles importantes e que eu não havia contemplado. Assim, a atualização do roteiro foi constante e esteve diretamente ligada ao próprio processo de realização das entrevistas, que se encontram, em versão editada, anexadas em disquete.

A seleção final dos entrevistados considerou o serviço que tivesse significativa diversidade profissional, em contrapartida à especificidade maior da assistência que oferece; cuja maioria dos membros da 'equipe' estivesse pelo menos cinco anos trabalhando juntos e, por fim, o serviço cujos profissionais e responsáveis se mostrassem interessados em participar desta segunda fase. Além disso, como havia decorrido um ano desde o primeiro contato com a maioria dos serviços, era preciso que a equipe ainda fosse a mesma

O serviço que melhor obedecia a esses critérios fundamentais era o Hospital Dia Infantil em Saude Mental da Moóca. Meu primeiro contato com o HDI da Moóca foi em 30.10 .2001 , por ocasião da primeira fase da coleta de dados e o início

\footnotetext{
2 Essa discussão encontra interlocução com os estudos do trabalho sobre os setores bancário e
} automobilístico, que também têm destacado esse aspecto da subjetividade no trabalho. Sobre o setor 
das entrevistas foi em 08.10 .2002 , com a diretora da unidade, que havia submetido minha solicitação à equipe, para a qual apresentei novo parecer do Comitê de Ética em Pesquisa da Secretaria Municipal de Saúde (ANEXO 6), autorizando mais uma vez minha entrada no serviço. A partir daí, fui apresentada a alguns membros da equipe e passei a agendar as demais entrevistas pessoalmente, por intermédio dos profissionais que iam sendo entrevistados.

A segunda fase do trabalho de campo transcorreu entre os meses de outubro de 2002 e fevereiro de 2003. Realizei nove entrevistas, todas gravadas, com os profissionais que estavam disponiveis nesse período. Aqueles que não participaram da pesquisa estavam de licença ou em férias, de modo que não foi possivel esperá-los retornarem ao serviço dado o adiantado do tempo, tendo sido contemplado pelo menos um profissional de cada categoria ocupacional de nível universitário.

Os participantes demonstraram uma atitude receptiva em relação à pesquisa e, de modo geral, não se inibiram para falarem de sua vida profissional e da política atual. A abordagem qualitativa, neste caso, revelou-se importante para o esclarecimento de algumas questões ligadas à estrutura organizacional da Prefeitura e da própria modalidade hospital dia infantil.

Todo o processo foi muito rico, desde o contato com os profissionais até o conteúdo das entrevistas, com suas trajetórias e expectativas. Acredito que a entrevista tenha se colocado, para os entrevistados, como um espaço de reflexão a mais sobre suas práticas cotidianas e sobre o trabalho que realizam como um todo. Momento de lembrar, que rompe com o cotidiano: distanciamento necessário e 
possibilidade de reflexão crítica imediata. De minha parte, aceitei e reconheci certas reservas manifestadas em determinados momentos das entrevistas ${ }^{3}$.

As entrevistas foram gravadas em fita cassete, totalizando aproximadamente 740 minutos de gravação, e transcritas para a posterior análise no âmbito da metodologia qualitativa. Como a linguagem oral, também denominada coloquial, se vale das repetições, utiliza termos onomatopéicos, privilegia o fluxo das idéias em detrimento das regras que regem o texto escrito, a transcrição das entrevistas constitui-se em um recurso de decodificação de linguagem que exige várias audições do material gravado para que o sentido do que foi dito não seja distorcido. Além disso, ao transcrever as fitas deve-se estar atento às nuances, silêncios, entonações que se expressam pelo uso da pontuação.

Para transcrever cerca de 12 horas de entrevista, contei com a colaboração de duas transcritoras, além de mim. Combinamos os termos da transcrição a partir dos aspectos acima mencionados, de modo que as transcrições ficassem o mais próximo possivel do que estava registrado e também entre si. Após a transcrição de cada fita, nova audição era feita para corrigir eventuais falhas, sobretudo entre as que eu não tinha transcrito (PRETI 1993).

O material impresso foi objeto de várias leituras, mas as primeiras ainda foram feitas para corrigir erros de digitação e compreensão. Numa primeira edição, vícios de linguagem foram eliminados, repetições excessivas de algumas expressões, padronizando-se, assim, o estilo empregado no conjunto das entrevistas, na busca de clareza e concisão textual. Certas palavras soltas, inversões gramaticais que

\footnotetext{
${ }^{3}$ Essa idéia de que as técnicas de entrevista (história oral, história de vida) exercitam a memória de quem é entrevistado e isso contribua com reformulações ou gere outras elaborações a respeito do que
} 
dificultavam a compreensão do texto foram substituidas pela ordem direta, assim como algumas concordâncias verbais foram acertadas, uma vez que a interpretação empreendida no presente estudo considera exclusivamente o conteúdo verbal do discurso (PIROTTA 2002).

Numa segunda edição, foram eliminados trechos das entrevistas que se repetiam, assim como os nomes de pacientes citados foram substituídos por suas iniciais, quando havia muita proximidade destes com o entrevistado em questão apareceram representados entre parênteses por expressões do tipo: (o garoto). Palavras subentendidas ou referências indiretas também aparecem entre parênteses, e quando o entrevistado referiu-se a coisas que disse em outras situações ou ditas por terceiros, foram utilizadas aspas. Ao final desta edição, encaminhei para cada entrevistado suas entrevistas para que lessem e corrigissem alguns aspectos que por ventura julgassem necessários, o que também contribui com a edição final.

Cabe ressaltar que este trabalho minucioso de revisão e edição foi feito sempre com a máxima preocupação em preservar o sentido original do que foi dito. Os nomes dos profissionais entrevistados e outros a que fazem referência foram mantidos, de acordo com o consentimento livre e esclarecido de cada um (Anexo 7), pois revelam filiações ideológicas e teóricas que interessam para o estudo, contudo nos capítulos seguintes, quando aparecem destacados alguns trechos, são indicadas apenas as iniciais de cada entrevistado, cujo nome completo poderá ser encontrado no capítulo 4 ou nas entrevistas em anexo. 
A análise do material foi realizada, em principio, individualmente e num segundo momento, cada narrativa foi interpretada com referência às demais e a riqueza de informações pôde ser contemplada pela abordagem qualitativa, onde as situações particulares e delimitáveis, o estudo de casos especificos, permitem uma aproximação da percepção que as pessoas têm da realidade que as cerca (MINAYO 1993; 1995), no caso, o cotidiano de práticas profissionais no âmbito da saúde mental.

Em termos de procedimentos de leitura das narrativas, esse processo compreendeu três momentos: o primeiro correspondeu às primeiras leituras de cada entrevista, realizadas com base no roteiro, cujo objetivo foi tomar contato com os relatos impressos, portanto com os temas que apareciam em cada entrevista e com aqueles que eram recorrentes, podendo, assim, ser montada uma grade de interpretação provisória; num segundo momento, fez-se uma leitura apurada de cada relato isoladamente, em que se enunciam as singularidades. São as chamadas leituras verticais; e, por fim, as leituras horizontais, em que tais singularidades são tematizadas de acordo com aquela grade provisória, que se atualiza ao longo deste processo de impregnação e interpretação, direcionadas pelos referenciais teóricos que orientam o presente estudo (BARDIN 1997).

Essas narrativas ofereceram diversas possibilidades de interpretação. Contudo, visando a compreensão das práticas profissionais e das representações pessoais e coletivas em relação ao trabalho que os entrevistados realizam, foi oportuno organizar a análise conjunta das narrativas, segundo três eixos norteadores: 
1. Os aspectos da experiência de cada sujeito entrevistado, em que foram contempladas trajetórias de formação e trajetórias profissionais, concepções sobre as diferentes atividades que desenvolveram e reflexão sobre as atividades que desenvolvem atualmente, individuais e coletivas;

2. Os contextos em que são vivenciadas as práticas profissionais pelos sujeitos, considerändo o ambiente físico e as condições materiais de trabalho, a relação inter-pessoal, a percepção acerca da organização das atividades do serviço e as atuais diretrizes que as orientam;

3. As representações acerca do trabalho em saúde mental: reflexão sobre a própria natureza do objeto de intervenção da saúde mental, sobre a relação entre os objetivos da mesma e a composição dos saberes e conhecimentos, e a avaliação sobre a articulação que fazem entre os saberes técnicos e operantes. 


\subsection{Referenciais teóricos}

Tendo em vista a temática em questão, os aportes teóricos que orientaram este estudo inscrevem-se nos estudos do trabalho em saúde, direcionados pela categoria trabalho, que constitui um dos eixos teóricos de grande importância para a análise das políticas estatais de financiamento da produção da assistência em saúde, das problemáticas da institucionalização e mercantilização da medicina e das novas relações e condições de trabalho que dai decorrem. Permite, ainda, a aproximação teórica e prática da teoria marxista ao campo da saúde e conseqüente conformação dos elementos característicos do processo de trabalho em saúde.

Pesquisar os serviços de saúde não consiste tarefa fácil, tanto do ponto de vista operacional, considerando aí o próprio delineamento da investigação à construção metodológica da pesquisa, até sua conexão com os aportes teóricos que devem dar sustentação e legitimidade aos dados encontrados e resultados trabalhados e apresentados. A articulação, portanto, entre as dimensões empirica e teórica da pesquisa parece ser uma questão importante, sobretudo quando o objeto em estudo é justamente tal articulação na prestação da assistência em saúde.

A vivência do pesquisador nos serviços, por sua vez, pode consagrar essa cisão, na medida em que parece ser este um dos elementos mediadores entre os dois domínios, de tal sorte que dependendo do espirito do "sujeito" é possivel um distanciamento menor entre esses dois mundos ou uma desconexão total. Na verdade, em se tratando de serviços de saúde, existem outras possibilidades de que esta articulação aconteça, sobretudo porque a organização dos serviços não pode 
prescindir às politicas de saúde e sua efetivação ou concretização. Neste processo, aparecem as tecnologias mediadoras à serviço da articulação das dimensões técnicas e operacionais: a "implantação" e "avaliação" de projetos ou programas de saúde, cuja eficácia e alcance configuram outra discussão, não menos imperiosa.

Com efeito, é possível pensar sobre os serviços de saúde sob diversas perspectivas e a escolhida neste estudo considera a prestação da assistência como o resultado das ações desenvolvidas nos serviços, realizadas em relativa consonância com as diretrizes oficiais e a partir de alguns instrumentos especificos e de seus agentes, sujeitos dessa instrumentalização, com a qual estabelecem uma relação profissional, remetendo a assistência à saủde ao processo de trabalho que configura.

Desta forma, parte importante da produção intelectual contemporânea no campo da saúde coletiva tem discutido o trabalho em saúde. Assim, como já enunciado na introdução desta tese, são esses estudos que forneceram as bases teóricas para a leitura da "prática" a que me propus.

Os autores considerados partem da categoria trabalho e as reflexões daí decorrentes assinalam vários aspectos e desdobramentos. A análise das politicas públicas de saúde e de seus mecanismos de financiamento foi investigada, inicialmente, por DONNANGELO (Op. Cit.); AROUCA (1975); BRAGA (1978). Dessa discussão e debate surgiu a problemática da mercantilização da medicina, processo que desencadeou novas relações e condições de trabalho em saúde, ressaltando a autonomia profissional médica e para entendê-las foi necessário, por exemplo, recuperar a historicidade das práticas de saúde, localizando os aspectos sociais que deflagraram tal processo (DONNAGELO \& PEREIRA, Op. Cit.). A 
abordagem histórica dessas práticas descortina as contradições inerentes aos processos históricos e sociais e possibilita o enfrentamento - ainda que teórico - das reciprocidades entre as práticas de saúde e a totalidade social que integram, localizando nesse movimento os sujeitos historicamente, como produto e re-produtor da estrutura social.

Os estudos seguintes, nessa mesma linha, investigaram a própria configuração do processo de trabalho em saúde e seus elementos intrínsecos e fundadores. Atualizando a conexão entre ciência e questões sociais, MENDES-GONÇALVES (1992; 1994) adota a categoria trabalho, que lhe permitiu pensar sobre as práticas de saúde como trabalho, ou seja, como atividade sistemática e meio de satisfação de necessidades individuais (valor de uso), obedecendo a uma sucessão de operações que vão se complexificando ao longo do tempo, de acordo com o incremento daquelas necessidades, que passam a ser socialmente determinadas e, neste aspecto, a própria finalidade do trabalho e seus instrumentos vão assumindo outros valores, como o de troca.

Em seu estudo sobre o trabalho médico, transpõe para o campo da saúde a teoria marxista do trabalho, segundo a qual as relações de produção estão na base da constituição da sociedade moderna - portanto da medicina moderna - transformando os individuos em instrumentos da ação (do trabalho). Decorrem dai as idéias de mecanização, rotinização, alienação, que se atrelam ao chamado trabalho manual. Assim como a crítica marxiana a essa noção de trabalho manual - a impossibilidade de dissociação total entre as dimensões intelectual e operacional -, o autor sinaliza que o 
agente só terá dominio sobre sua ação caso detenha seu saber operante. (MARX, 1988; MENDES-GONÇALVES, Op. Cit.).

Ao introduzir esta categoria para o trabalho em saúde, as reflexões do autor permitem pensar os projetos de trabalho em saude. e o projeto é a dimensão em que todas as exigências. os constrangimentos e determinantes do trabalho. são colocados para a ação. De outro lado, podemos explorar nessa categoria a situação oposta ao trabalho industrial, quer dizer. o trabalhador em saúde como detentor desse saber... não um aplicador mecânico direto do saber, ou a serviço imediato da máquina, como instrumento coisificado da própria ciência. mas como seu mediador, no trabalho! (SCHRAIBER et. al. 1997; p: $6)$.

Entretanto, as formas de conexão entre objeto, instrumentos e atividades do trabalho podem variar e constituir distintos processos de trabalho. Ora, no campo da saúde, as demandas e necessidades de cuidados são o ponto de intersecção entre os distintos processos de trabalho das diversas áreas profissionais e saberes operantes, que apreendem tais necessidades sob um aspecto próprio mas sempre no âmbito da prestação de assistência à saúde.

Nesta direção, SCHRAIBER e PEDUZZI (1999) focalizam as intersubjetividades representadas pelos diversos trabalhadores que compõem a assistência em saúde com o médico, profissional privilegiado no âmbito desse coletivo de trabalhadores, distinguindo processo de trabalho e processo de produção de serviços de saúde. O primeiro se expressa pelo cotidiano da prestação da assistência, no caso, 
pela divisão técnica do trabalho entre os diversos profissionais que compõem a assistência. Desta forma, a subjetividade de cada trabalho específico favorece o debate entre teoria e prática, portanto, entre conhecimento cientifico e trabalho, amplificando as mediações entre interdisciplinariedades e interprofissionalidades.

Quanto ao aspecto da produção de serviços, esta refere-se à capacidade institucional de articulação entre os domínios técnico e operante no âmbito do agenciamento e fomento das politicas e deve acompanhar as novas regras e mudanças no mundo do trabalho e da moderna reestruturação produtiva em que a categoria "serviço" assume conotações importantes e perigosas, sobretudo para os sujeitos que o oferecem diretamente, pois a peculiaridade do objeto de trabalho da saúde (o cuidado a saúde) acarreta a impossibilidade de uma normatização por completo das funções técnicas dos variados agentes e, portanto, a dificuldade de definição de rigidos critérios econômicos de produção. De acordo com RIBEIRO (1995), é possivel pensarmos nas diversas áreas profissionais da saúde como serviços particulares e também como processos de trabalho especificos.

Como processo de trabalho, portanto, o trabalho em saúde comporta núcleos de atuação autônomos, com objetos, instrumentos e saberes próprios, caracterizando os vários processos de trabalho que o constituem Assim, as relações interpessoais entre os agentes e entre estes e os usuários dos serviços possibilitarão a ampliação das intervenções técnicas, dos saberes, pois é neste âmbito intersubjetivo (relação agentes-usuários) que se dá o reconhecimento das demandas de saúde. Ou seja, quando comparado às dimensões manuais do mundo do trabalho contemporâneo, de forma geral, o trabalho em saúde reserva essas peculiaridades importantes. 
No que se refere ao conteudo do trabalho ${ }^{4}$, mudanças podem ser percebidas no setor saude, tais como: a flexibilidade na produção da assistência, deflagrada pelas necessidades de saúde e conseqüente necessidade de respostas adequadas e singularizadas; alto ritmo das inovações técnicas, percebido desde os anos 30 , e a incorporação de novas tecnologias; o intenso processo de divisão do trabalho e a decorrente necessidade de recomposição dessa divisão, como dito anteriormente.

A terceirização, processo que não apenas acirra a divisão do trabalho mas o precariza, ainda se restringe aos postos de trabalho operacionais no setor público de saúde, mas já pode se observada na própria assistência, no setor privado 5 .

Portanto, a institucionalização das práticas de saúde como "prestação de serviços" fragmenta e cerceia novamente o trabalho em saúde, restringindo a autonomia dos seus agentes. Em resposta a esta "armadilha", recoloca-se o aspecto da intersubjetividade e da qualificação para o exercício das intervenções.

O conceito de autonomia profissional tem sido estudado por SCHRAIBER (1993;1995) e RIBEIRO e SCHRAIBER (1994), e se refere, também, ao trabalho médico e, posteriormente, ao trabalho em saúde em geral. Inspirada nos estudos de NOGUEIRA (1967) e FREIDSON (1978), em que discutem o conceito de profissão, considerando a estrutura geral de produção da sociedade como trabalho além das dimensões do conhecimento e do especialismo que encerram, a autora localiza na

\footnotetext{
"As noçōes de "conteúdo do trabalho" e "cadeia" têm sido usadas por alguns estudos acerca da reestruturação produtiva do trabalho industrial para designar suas dimensões intelectuais, atreladas às novas exigèncias de qualificação $e$ formação profissionais, indicando novas formas de gestão $e$ organização da produção e do trabalho, tais como a introdução de grupos de trabalho, trabalho polivalente, células de produção, programas de qualidade total, entre outras, gerando novos niveis hierárquicos entre os diversos trabalhadores e setores (LEITE e RIZEK 1988).

${ }^{5}$ PIRES (1996) citada por PEDUZZI (1998) refere que, paralelamente ao processo de reestruturação da produção material do trabalho em saúde, é possivel observarmos uma tendência de formação do
} 
problemática da autonomia profissional duas esferas de intervenção: a de natureza biológica, voltada para o controle dos fenômenos fisiológicos, centradas no trabalho médico; as de natureza social, voltadas para aspectos mais singulares, portanto menos quantificáveis, sobre os quais as demais áreas atuam. As primeiras, identificadas com maior grau de complexidade técnica, conferem a seus agentes maior poder decisório e consagraram a hegemonia médica do trabalho e assistência à saúde.

A extensão da autonomia técnica para os demais profissionais de saúde (nãomédicos) acontece à medida em que se percebe que os objetos de intervenção não são fixos, ao contrário: são dinâmicos como a própria dinâmica cultural em que se inserem; e a reflexão sobre os projetos assistenciais exigirả o compartilhamento e a assunção de várias perspectivas, portanto, do conhecimento e competências técnicas de outros profissionais que integram a equipe de trabalho, sendo que esses graus de autonomia poderão variar de acordo com a legitimidade e reconhecimento que passam a desfrutar junto a sociedade.

Esta temática da divisão e recomposição do trabalho em saúde tem sido referida, no campo saúde coletiva, à problemática dos recursos humanos ${ }^{6}$, e como já mencionado, diz respeito a distintos trabalhos especializados, constituindo processos

que chamou de redes assistenciais para caracterizar a terceirização de algumas áreas do trabalho assistencial.

${ }^{6}$ Diversos autores, entre os quais NOGUEIRA (1987) e PAIM (1994), tèm chamado a atenção para o fato da utilização indistinta dos termos: recursos humanos, trabalhadores em saúde, profissionais da saúde, força de trabalho em saúde, salientando que existem origens e implicações teóricas bastante diversas para o entendimento a respeito do trabalho em saúde. O conceito de recursos humanos, por exemplo, tem sua origem nas teorias da administração e, grosso modo, remete à idéia de que o trabalhador é um componente "coisificado" do processo de trabalho. Neste sentido, PAIM (Op. Cit.) observa que, embora seja um campo de conhecimento já estabelecido, é necessário uma reflexão critica sobre a temática, que possibilite novos recortes e abordagens e resitue a questão dos recursos humanos na direção da construção de novas práticas. 
mais ou menos conexos e complementares, cuja conjugação amplia as possibilidades de eficiência e eficácia do entendimento e atendimento das necessidades de saúde.

Tal interdependência e complementaridade das ações de saúde, engendradas pelo reconhecimento da multidimensionalidade do objeto da saúde e conseqüente especialização, remetem a questão do trabalho em equipe multiprofissional. PEDUZZI (1998), refletindo sobre esta problemática, sugere que o trabalho em equipe consiste numa certa modalidade do trabalho coletivo, em que se observa uma distinção entre equipe agrupamento e equipe integração (1988; p.27). Nas duas modalidades de equipe identifica-se o plano das ações e o plano dos agentes, sendo que na equipe do tipo agrupamento ocorre uma "justaposição" entre os dois planos mencionados, enquanto que no tipo integração, a articulação entre ação, agentes e saberes técnicos é facilitada pelos canais de comunicação construídos pelos sujeitos do trabalho.

Para a compreensão objetiva da instância da comunicação, a autora lança mão da leitura habermasiana do trabalho, que considera a interação social ou ação comunicativa entre os agentes do trabalho como o resultado da experiência da autoconsciência, portanto, do próprio processo dialético de formação do sujeito e construção de uma identidade racional. Tal processo de formação da subjetividade incide sobre a dialética entre trabalho e interação, na qual o primeiro consiste em uma ação instrumental éou ação estratégica, caracterizando-se como ação racional dirigida a fins, ou seja, ação que busca da melhor racionalização possivel na relação meios-fins (HABERMAS 1994; p.57 citado por PEDUZZI 1998); e a segunda, a uma ação comunicativa simbolicamente mediada e orientada por normas 
de vigência obrigatória que definem as expectativas reciprocas de comportamento. $e$ que têm de ser entendidas e reconhecidas. pelo menos por dois sujeitos agentes (IDEM).

O entendimento mútuo e a intersubjetividade agente-agente caracterizam o que a autora define como trabalho em equipe. Assim:

o trabalho em equipe constituiria uma prática em que a comunicação entre os profissionais faz parte do exercicio cotidiano do trabalho e os agentes operam a articulação das intervenções técnicas por meio da mediação simbólica da linguagem. Neste sentido, há que se considerar duas dimensões inerentes ao trabalho em equipe: a articulação das ações $e$ a interação dos profissionais (CIAMPONE e PEDUZZI 2000; p. 144).

No tocante a multiprofissionalidade, que também caracteriza a equipe de saúde, o aspecto da interação se direciona às intersecções entre as intervenções técnicas peculiares de cada área profissional. Ou seja, as interprofissionalidades garantem, por um lado, o reconhecimento e certa preservação das especificidades; por outro, implicam uma "flexibilização" das fronteiras entre as diversas áreas profissionais envolvidas, em que pode-se recolocar a hierarquia entre os trabalhos especializados.

Essa dinâmica das interprofissionalidades implica a recuperação de conceitos já mencionados ao longo deste estudo, como os de saber e interdisciplinaridade.

No que se refere ao trabalho em saúde, o que instrumentaliza as ações e distingue, técnica e socialmente, os trabalho especializados é o saber operante, - 
técnico ou tecnológico -, sendo que cada trabalho especializado configura domínios de campos especificos de conhecimento, que conferem autonomia técnica aos respectivos agentes. Entretanto, a aplicação do conhecimento científico não se dá de forma direta e imediata no trabalho cotidiano, decorrendo daí a distinção entre interdisciplinaridade e multiprofissionalidade, entre ciência e saber.

FOUCAULT (1999) aponta que o saber constitui um campo mais abrangente em relação a ciência. $O$ autor define o saber como:

"o conjunto de elementos formados de maneira regular por uma prática discursiva e que são indispensáveis à constituição de uma ciência, apesar de não se destinar necessariamente a lhe dar lugar; o dominio constituido pelos diferentes objetos que adquirirão ou não um estatuto cientifico; o espaço em que o sujeito pode tomar posição para falar dos objetos de que se ocupa em seu discurso; e ainda como o campo de coordenação e subordinação dos enunciados, em que os conceitos aparecem. definem-se, são aplicados e se transformam. Por fim, um saber se define pelas possibilidades de utilização e de apropriação oferecidas pelo discurso, de forma que pode haver saberes que são independentes das ciências, mas não há saber sem prática discursiva definida e toda prática discursiva pode definir-se pelo saber que ela forma. No interior de cada campo de saber encontram-se inscritas ciências, que em uma análise arqueológica podem ser apreendidas em diferentes limiares de epistemologização, de cientificidade e de formalização" (FOUCAULT Op.Cit.; p.54). 
Essa passagem da ciência ao saber foi examinada pelos já mencionados estudiosos do trabalho em saúde. DONNANGELO (1976); MENDESGONÇALVES (1994); SCHRAIBER (1997), ao investigarem o trabalho médico, referem que este como prática não se confunde com a prática científica, embora dela dependa para sua legitimidade e eficácia. Como prática, o saber médico constitui uma ação técnica (diagnóstica e terapêutica) direcionada para a cura, que ocorre na interação profissional-usuário e na interação destes com o sistema de saúde. O mesmo ocorre com as demais áreas profissionais da saúde.

Assim, o objeto de intervenção não é o mesmo objeto do conhecimento. Para lidarem com o primeiro, os agentes necessitam recuperar na experiência prática os conteúdos científicos, atualizando-os. Portanto, ao pontuarem uma distinção entre saber operante e saber tecnológico, os autores pontuam o momento que se interpõe ciência e trabalho.

Corroborando com as perspectivas acima enunciadas, MERHY (1997) acrescenta uma classificação das tecnologias envolvidas no trabalho em saúde, a saber: as tecnologias de relação que definem a produção de vínculo e acolhimento entre agentes e usuários: aquelas que se referem aos saberes mais estruturados e tradicionais, tais como a clinica médica e a clínica psicanalitica e as que consistem em recursos tecnológicos como os modernos equipamentos e novas normas organizacionais.

Ora, enquanto a interprofissionalidade diz respeito diretamente a divisão do trabalho, a interdisciplinaridade representa, para o campo da saúde coletiva, a 
possibilidade de integração de diversos saberes e intervenções (MINAYO 1993; 1995; ALMEIDA FILHO 1997; SPINK 1997).

Tais reflexões acerca da interdisciplinaridade não são recentes e remontam a própria preocupação com a adequação da formação universitária com as demandas sócio-econômicas. JAPIASSÚ (1985) enfoca a interdisciplinaridade entre as ciências sociais, entendendo-a como exigência interna destes campos disciplinares e também de fatores extra-científicos, a medida que impõe-se para o homem responder às suas necessidades. Tais exigências, segundo o autor, são o próprio revés da especialização das disciplinas cientificas. Longe de ser uma questão consolidada, a retomada do debate sobre a interdisciplinaridade na contemporaneidade configura um projeto em construção, desde o entendimento sobre a terminologia utilizada para referi-la: multidisciplinaridade, pluridisciplinaridade e transdisciplinaridade.

As primeiras denominações evocam um agrupamento dos recursos de várias disciplinas num determinado trabalho sem, entretanto, uma conexão mutua entre as diversas disciplinas. No caso de disciplinas correlatas, é possivel algum grau de integração, definindo-se, a seguir, uma hierarquia entre elas, configurando uma campo disciplinar. A transdiciplinaridade, por sua vez, corresponde ao compartilhamento total dos diversos campos do conhecimento, sem a eliminação da competència dos diversos campos disciplinares ${ }^{7}$.

\footnotetext{
A problemática da transdisciplinaridade encontra particular relevância e alcance na obra de MORIN (1990), citado por Peduzzi (1998), em que propõe uma ciència da complexidade que reconheça a relação sujeito-objeto como intrinseca ao conhecimento, e este como a possibilidade de
} 
Assim, embora tais abordagens sobre as disciplinaridades pareçam restritas ao âmbito acadêmico, elas permeiam as praticas de trabalho, sobretudo frente a complexidade dos objetos de intervenção das diversas áreas de atuação em saúde. Ou sejā, o conhecimento subsidia as ações dos agentes e thes confere um caráter interdisciplinar, ao mesmo tempo delimitando as diversas áreas profissionais que trabalham coletivamente e integrando os respectivos saberes na prática.

Portanto, ambas as esferas, da interdisciplinaridade e multiprofissionalidade (ou interprofissionalidade), estão buscando novas formas para contemplarem a multidimensionalidade dos objetos do campo da saúde e o exercicio do trabalho em equipe é um dos caminhos, permeado pelas representações dos agentes e pela mediação entre estas, conhecimento e saber operante, a partir do qual se esboçam possibilidades não apenas de integração das disciplinas científicas, mas de transformação e renovação do próprio campo da Saúde Coletiva. apreender os fenômenos combinando os princípios
ordem/desordem/interação/organização. 


\title{
3
}

\section{Caracterização do trabalhador de saúde mental: fazendo uma primeira costura}

\author{
Já não penso em ti. Penso no oficio \\ a que te entregas. Estranho relojoeiro. \\ cheiras a peça desmontada: as molas unem-se. \\ o tempo anda. És vidraceiro. \\ Varres a rua. Não importa \\ que o desejo de partir te roa; e a esquina \\ faça de ti outro homem: e a lógica \\ te afaste de seus frios privilégios. \\ Há o trabalho em ti, mas caprichoso. \\ mas benigno, \\ e dêle surgem artes não burguesas, \\ produtos de ar e lágrimas. indumentos \\ que nos dão asa ou pétalas, e trens \\ e navios sem aço, onde os amigos \\ fazendo roda viajam pelo tempo, \\ livros se animam, quadros se conversam, \\ e tudo libertado se resolve \\ numa efusão de amor sem paga, e riso. e sol. \\ O oficio é o oficio \\ que assim te põe no meio de nós todos, \\ vagabundo entre dois horários; mão sabida \\ no bater, no cortar, no fiar, no rebocar. \\ o pé insiste em levar-te pelo mundo. \\ a mão pega a ferramenta: é uma navalha. \\ $e$ ao compasso de Brahms fazes a barba \\ neste salão desmemoriado no centro do mundo oprimido \\ onde ao fim de tanto silêncio e ôco te recobramos.
}

Carlos Drummond de Andrade. Canto ao homem do povo Charles Chaplin 
Neste capitulo, serão apresentados e comentados os dados referentes à primeira etapa da pesquisa de campo, que correspondem às informações acerca da formação profissional e situação ocupacional dos trabalhadores que integram a rede de serviços de saúde mental do Municipio de São Paulo, nas modalidades ambulatorial e hospital dia.

Vale lembrar ainda que, como gestora do Sistema Único de Saúde, a Secretaria Municipal de Saúde tornou-se responsável pela formulação e implantação de políticas e programas e pela regulação do sistema de saúde suplementar através das gerências das unidades de saúde, sob a gestão dos Distritos de Saúde, que passam a contar com apoio administrativo e orçamentário dos Postos Avançados (antigas Administrações Regionais de Saúde), ligados diretamente ao Gabinete do Secretário. Desta forma, buscando contemplar a descentralização gerencial e assistencial, a territorialização, a acessibilidade e a integralidade das ações, principios fundamentais do SUS, foram criados os 39 Distritos de Saúde (Figura 2). 


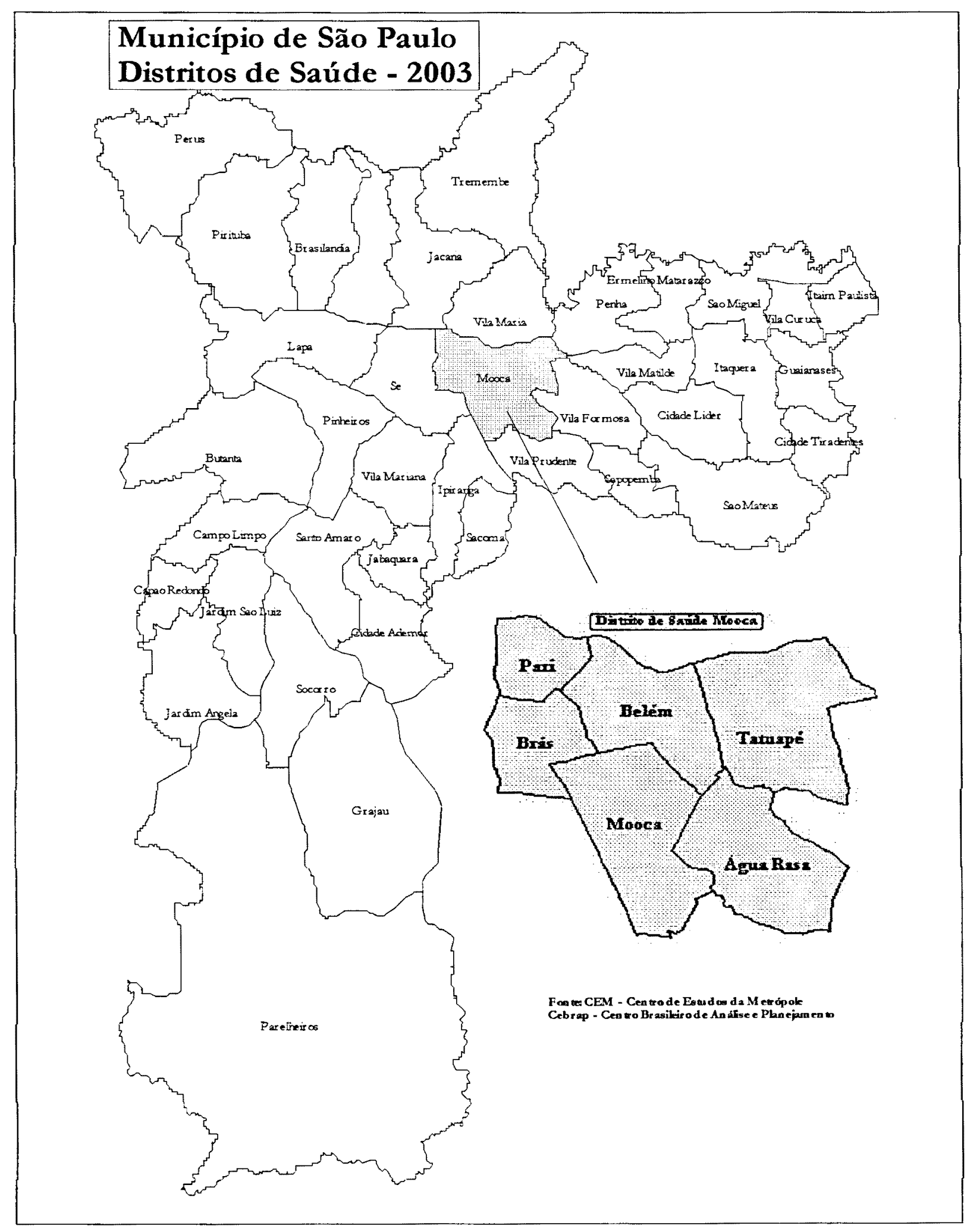




\subsection{Caracterização Geral dos Trabalhadores de Saúde Mental}

No período entre outubro de 2001 e setembro de 2002 existiam 638 profissionais nos serviços de saúde mental considerados por esse estudo, dos quais $47,8 \%$ correspondiam aos servidores de nível universitário e $52,2 \%$ aos não universitários. Apresenta-se, a seguir, uma caracterização inicial de todos os trabalhadores de saúde mental identificados pela pesquisa, segundo as seguintes variáveis: nível ocupacional, modalidade assistencial, categoria ocupacional e profissional.

Figura 3. Distribuição em percentagem dos Trabalhadores de Saúde Mental, segundo nível ocupacional. MSP, 2001/2002.

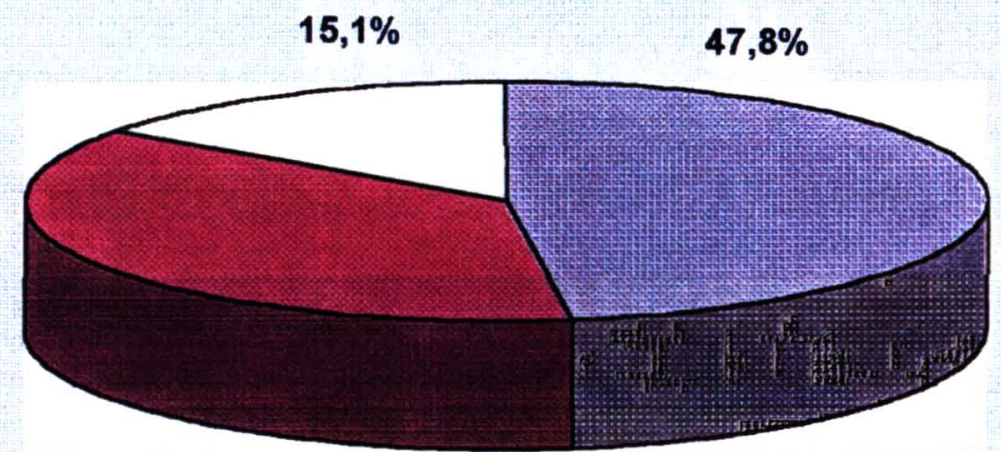

$37,1 \%$

\section{圆Universitários $\quad$ Nível Médico $\square$ Operacionais}

Existiam 305 trabalhadores de nível universitário (47,8\%), 237 de nível médio $(37,1 \%)$ e 96 de nivel elementar $(15,1 \%)$, revelando uma razão de proporcionalidade de $0,9 \%$ entre o grupo de universitários e o não universitário. 
Os trabalhadores de nível médio ocupavam, essencialmente, cargos e funções administrativas $(37,5 \%)$ e de suporte à assistência direta $(62,5 \%)$, sendo que entre as primeiras, encontramos maior concentração nos ambulatórios e nas segundas, uma distribuição bastante equivalente nas duas modalidades consideradas. Quanto aos operacionais, as funções ligadas à segurança, limpeza e enfermagem prevalecem substancialmente em relação às demais, ainda que segurança e limpeza correspondam a serviços terceirizados e a função de atendente de enfermagem tenda a desaparecer, pois estes agentes deverão estar mais qualificados. As outras funções foram identificadas apenas nos hospitais dia, o que indica diferença no padrão de lotação funcional entre a Prefeitura e o Estado.

Com o processo de municipalização na saúde, entretanto, essas diferenças também tendem a desaparecer, assim como as diversas nomenclaturas paras as mesmas funções e cargos, como o caso do auxiliar administrativo, que na Prefeitura é denominado ATA (auxiliar técnico administrativo) e no Estado, oficial administrativo.

Os auxiliares técnicos de saúde ainda são em número reduzido, mas correspondem aos profissionais especializados de nivel médio, que nas duas modalidades trabalhavam como auxiliares de farmácia Os visitadores sanitários, tão importantes no modelo de saúde pública no início do século XX, em São Paulo, sobretudo na atenção primária, foram identificados apenas na modalidade ambulatorial e mesmo assim referindo-se apenas ao cargo, pois os profissionais correspondentes realizavam outras funções, assistenciais ou administrativas (Tabela 2). 
Tabela 2. Trabalhadores Não Universitários, segundo ocupação $e$ modalidade assistencial. MSP, 2001/2002.

\begin{tabular}{|c|c|c|c|c|c|}
\hline \multirow{2}{*}{$\begin{array}{l}\text { Cargos e funções } \\
\text { Auxiliar Administrativo }\end{array}$} & \multicolumn{2}{|c|}{ Hospital Dia } & \multicolumn{2}{|c|}{ Ambulatório } & \multirow{2}{*}{$\begin{array}{r}\text { Total } \\
89\end{array}$} \\
\hline & 32 & $35,9 \%$ & 57 & $64,1 \%$ & \\
\hline & $19 \%$ & & $34,5 \%$ & & $26,7 \%$ \\
\hline \multirow[t]{2}{*}{ Auxiliar de Enfermagem } & 71 & $49,7 \%$ & 72 & $50,3 \%$ & 143 \\
\hline & $42,3 \%$ & & $43,6 \%$ & & $42,9 \%$ \\
\hline \multirow{2}{*}{ Auxiliar Técnico de Saúde } & 2 & $40 \%$ & $\mathbf{3}$ & $60 \%$ & 5 \\
\hline & $1,2 \%$ & & $1,8 \%$ & & $1,5 \%$ \\
\hline \multirow[t]{2}{*}{ Atendente de Enfermagem } & 8 & $38,1 \%$ & 13 & $61,9 \%$ & 21 \\
\hline & $4,8 \%$ & & $7,9 \%$ & & $6,3 \%$ \\
\hline Visitador Sanitário & 0 & & $\begin{array}{l}2 \\
1,2 \%\end{array}$ & $100 \%$ & $\begin{array}{r}2 \\
0,6 \%\end{array}$ \\
\hline \multirow[t]{2}{*}{ Telefonista } & 2 & $100 \%$ & 0 & & 2 \\
\hline & $1,2 \%$ & & & & $0,6 \%$ \\
\hline Copa/copeira & $\begin{array}{l}10 \\
5.9 \%\end{array}$ & $100 \%$ & $\boldsymbol{0}$ & & $\begin{array}{r}10 \\
3 \%\end{array}$ \\
\hline Serviço de Limpeza & $\begin{array}{l}20 \\
11,9 \%\end{array}$ & $83,3 \%$ & $\begin{array}{l}4 \\
2,4 \%\end{array}$ & $16,7 \%$ & $\begin{array}{r}24 \\
7,2 \%\end{array}$ \\
\hline Serviço de Segurança & $\begin{array}{l}17 \\
10,1 \%\end{array}$ & $54,8 \%$ & $\begin{array}{l}14 \\
8,5 \%\end{array}$ & $45,1 \%$ & $\begin{array}{r}31 \\
9,3 \%\end{array}$ \\
\hline Zelador & 2 & $100 \%$ & 0 & & $\begin{array}{r}2 \\
0,6 \%\end{array}$ \\
\hline Porteiro & $\begin{array}{l}3 \\
1,8 \%\end{array}$ & $100 \%$ & 0 & & $\begin{array}{r}3 \\
0,9 \%\end{array}$ \\
\hline \multirow[t]{2}{*}{ Trabalhador braçal } & $\begin{array}{l}1 \\
0,6 \%\end{array}$ & $100 \%$ & $\boldsymbol{\theta}$ & & $\begin{array}{r}1 \\
0,3 \% \\
\end{array}$ \\
\hline & 168 & $50,5 \%$ & 165 & $49,5 \%$ & 333 \\
\hline
\end{tabular}

Fonte: Pesquisa de Campo: 2001/2002. 


\subsection{Perfil dos trabalhadores de nivel universitário}

A seguir, os dados referentes aos trabalhadores de nível universitário segundo as seguintes variáveis: modalidade assistencial, idade no momento da entrevista, sexo do entrevistado, categoria profissional, tempo de trabalho no serviço público.

Figura 4. Distribuição em percentagem dos Trabalhadores Universitários, segundo modalidade assistencial. MSP, 2001/2002.

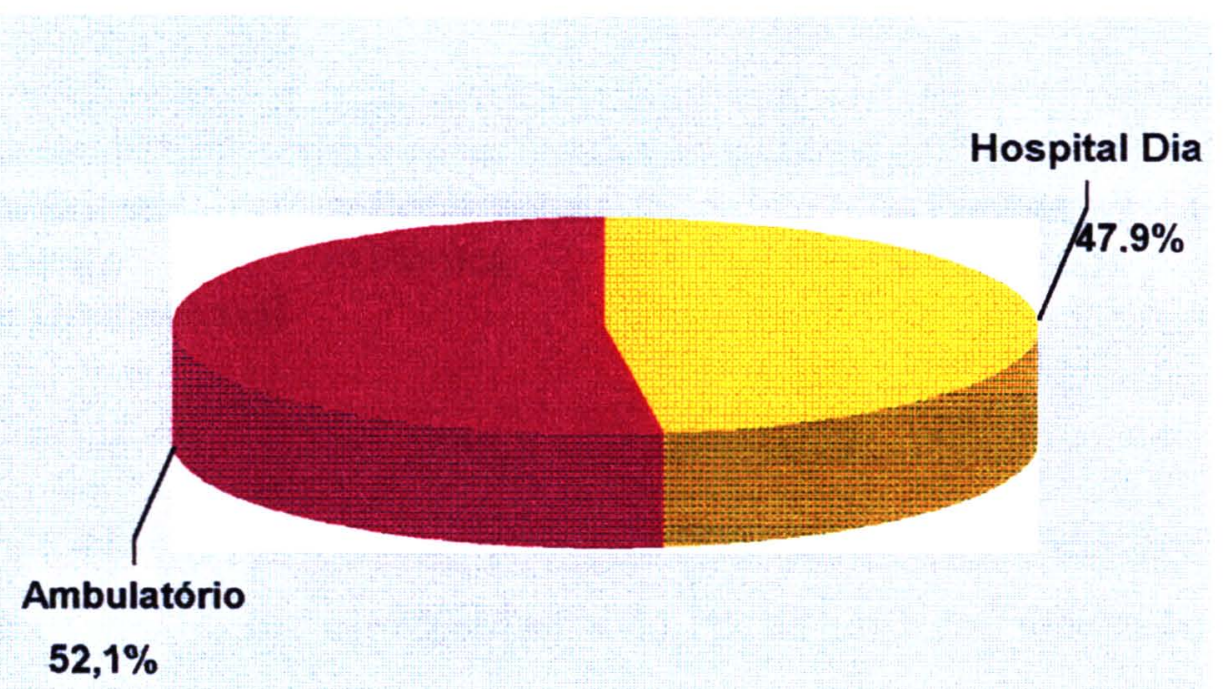

Dos 305 trabalhadores de nível universitário, 47,9\% estão nos hospitais dia e $52,1 \%$ pertencem aos ambulatórios, entre os quais estão incluídos os 2 primeiros centros de atenção psicossocial, sendo que na razão inversa, os HD's comportam maior número de trabalhadores de nível médico e operacional. De todo modo, nos 
dois casos (trabalhadores universitários e não universitários) a distribuição é bastante equivalente.

Figura 5. Distribuição em percentagem dos Trabalhadores Universitários, segundo categoria profissional. MSP, 2001/2002.

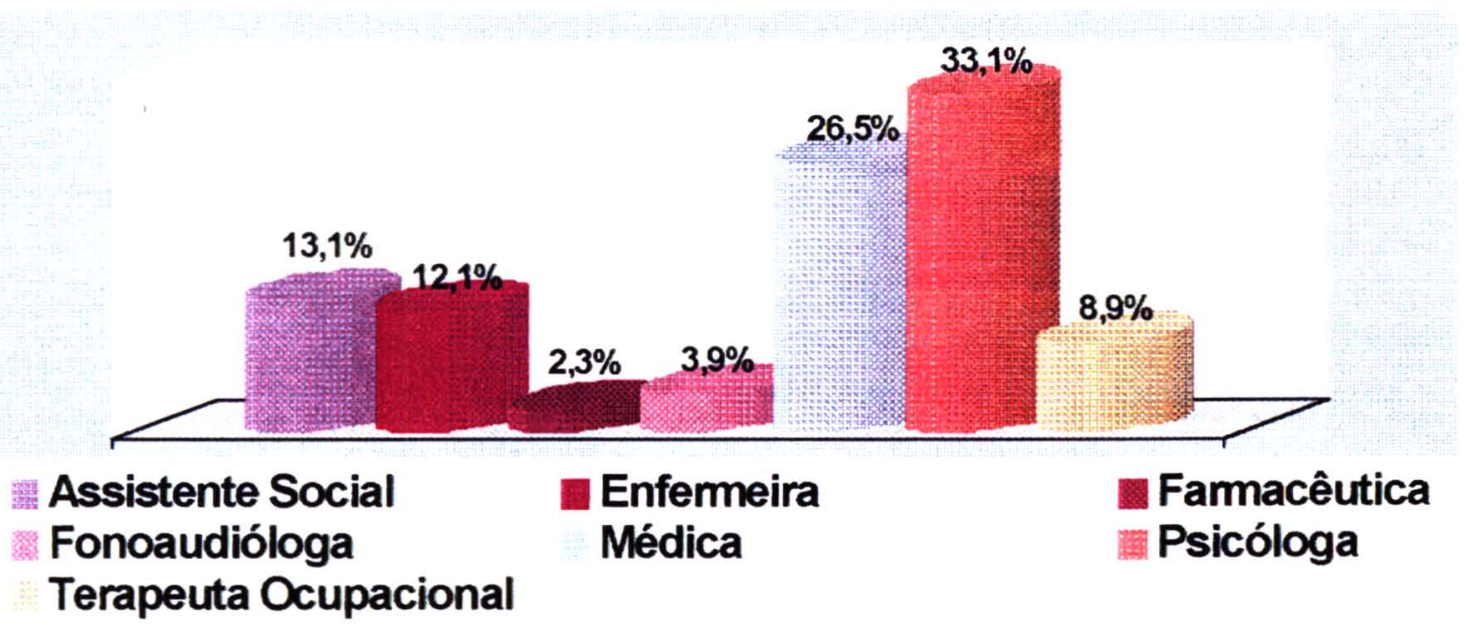

Os assistentes sociais correspondem a $13,1 \%$ do total dos trabalhadores universitários, os enfermeiros são $12,1 \%$, os farmacêuticos são $2,3 \%$, os fonoaudiólogos, $3,9 \%$, os médicos, $26,6 \%$, os psicólogos, $33,1 \%$ e os terapeutas ocupacionais, $8,9 \%$. Os profissionais assistentes sociais, enfermeiros, farmacêuticos e terapeutas ocupacionais são todos do sexo feminino. Entre os médicos, $54,3 \%$ são mulheres e entre os psicólogos, apenas $9,7 \%$ são do sexo masculino. 
Tabela 3. Categoria profissional dos trabalhadores Universitários, segundo modalidade assistencial. MSP, 2001/2002.

\begin{tabular}{lllllc}
\hline & \multicolumn{2}{c}{ Hospital dia } & \multicolumn{2}{c}{ Ambulatório } & Total \\
Categoria Profissional & \multicolumn{1}{c}{$40 \%$} & 24 & $60 \%$ & 40 \\
\hline Assistente Social & 16 & $40 \%$ & $15,1 \%$ & & $13,1 \%$ \\
& $10,9 \%$ & & 14 & $37,8 \%$ & 37 \\
Enfermeira(o) & 23 & $62,1 \%$ & 14 & $12,1 \%$ \\
& $15,7 \%$ & & $8,8 \%$ & & 7 \\
Farmacêutica(o) & 0 & & 7 & $100 \%$ & $2,3 \%$ \\
& & & $4,4 \%$ & & 12 \\
Fonoaudióloga(o) & 10 & $83,3 \%$ & 2 & $16,7 \%$ & $3,9 \%$ \\
& $6,8 \%$ & & $1,2 \%$ & & $51 \%$ \\
Médica(o) & 40 & $49,4 \%$ & 41 & $51 \%$ & $26,5 \%$ \\
& $27,4 \%$ & & $25,8 \%$ & & 101 \\
Psicóloga(o) & 37 & $36,6 \%$ & 64 & $63,4 \%$ & $33,1 \%$ \\
& $25,3 \%$ & & $40,2 \%$ & & 27 \\
Terapeuta Ocupacional & 21 & $77,8 \%$ & 7 & $25,9 \%$ & $8,9 \%$ \\
& $14,4 \%$ & & $4,4 \%$ & & 305 \\
\hline
\end{tabular}

Fonte: Pesquisa de Campo: 2001/2002.

A distribuição total dos profissionais universitários, como dito anteriormente, é bastante equivalente, comparando os percentuais dos hospitais dia e ambulatórios, sobretudo no que se refere à categoria médica. Os ambulatórios apresentam maior indice de psicólogos, sendo que estes profissionais correspondem a $33,1 \%$ do total dos profissionais universitários, seguidos pelos médicos $(26,5 \%)$. Os hospitais dia, por sua vez, concentram valores bem maiores de enfermeiros, fonoaudiólogos e terapeutas ocupacionais, que podem ser interpretados como expressão direta da realização de concursos públicos para provimento de cargos e funções para estas categorias profissionais, por um lado; por outro, representam o novo modelo de operacionalizaçào das ações de saúde implementado na rede municipal de saúde até final de 1992 
$\mathrm{O}$ número relativamente maior de assistente sociais nos ambulatórios pode ser em decorrência da política de saúde mental dos anos 80 , quando pelo menos um assistente social deveria compor com o psiquiatra e psicólogo a equipe mínima de saúde mental na atenção primária, como dito anteriormente (SES Op. Cit.).

\section{Figura 6. Distribuição em percentagem dos Trabalhadores Universitários,} segundo Idade no momento da entrevista. MSP, 2001/2002.

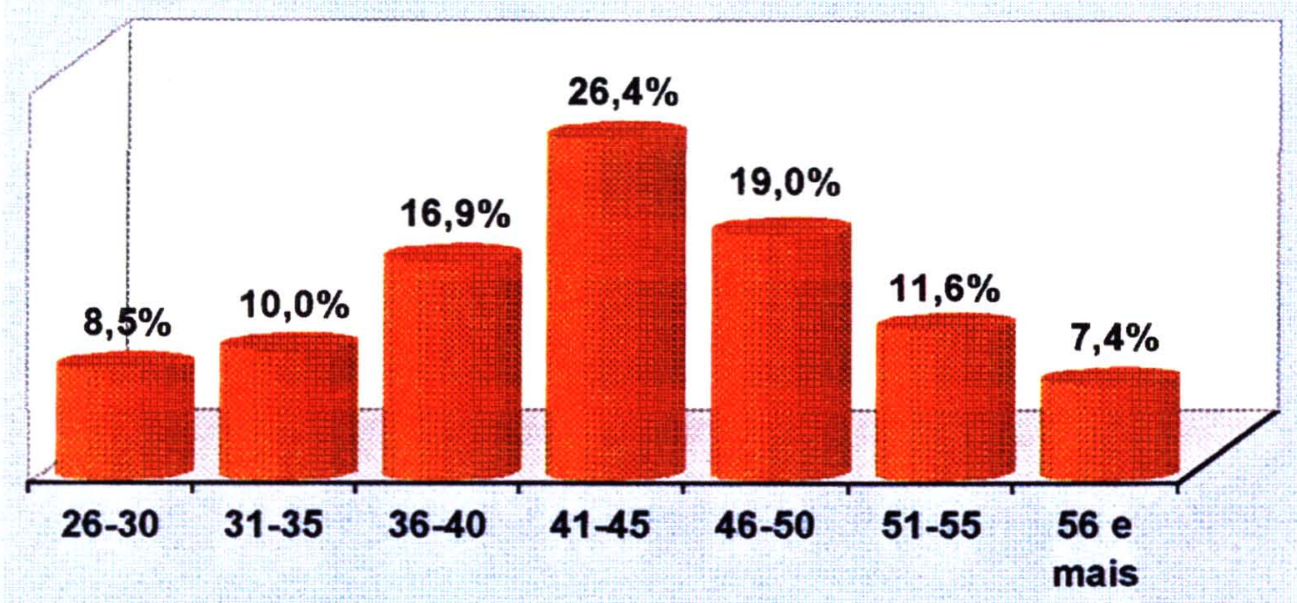

$13,7 \%$ não informaram a idade e entre os demais, a distribuição por faixa etária foi a seguinte: $26,4 \%$ tinha idade entre 41 e 45 anos; $19 \%$, entre 46 e 50 anos; $16,9 \%$, entre 36 e $40 ; 11,6 \%$, entre 51 e 55 anos; $10 \%$, entre 31 e 35 ; e os menores índices situaram-se nas extremidades: $8,5 \%$, entre 26 e 30 anos e $7,4 \%$ na faixa etária de 56 anos e mais. A média de idade foi de 43,2 anos e os valores mediano e modal foram 43 e 42 anos, respectivamente. $O$ desvio padrão foi de 8,3 anos. 
Figura 7 Distribuição em percentagem dos Trabalhadores Universitários, segundo Sexo. MSP, 2001/2002.

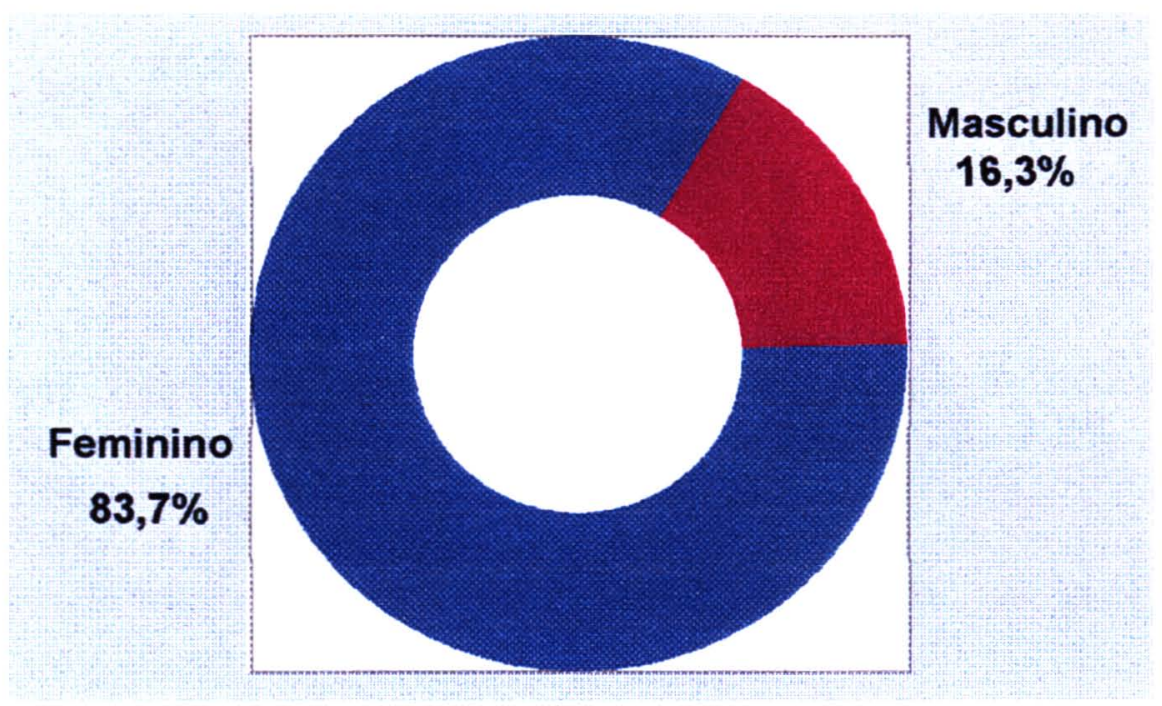

Em relação à variável sexo, $83,7 \%$ dos universitários eram do sexo feminino e $16,3 \%$, do sexo masculino. 
Figura 8. Distribuição em percentagem dos Trabalhadores Universitários, segundo tempo de trabalho no serviço público. MSP, 2001/2002.

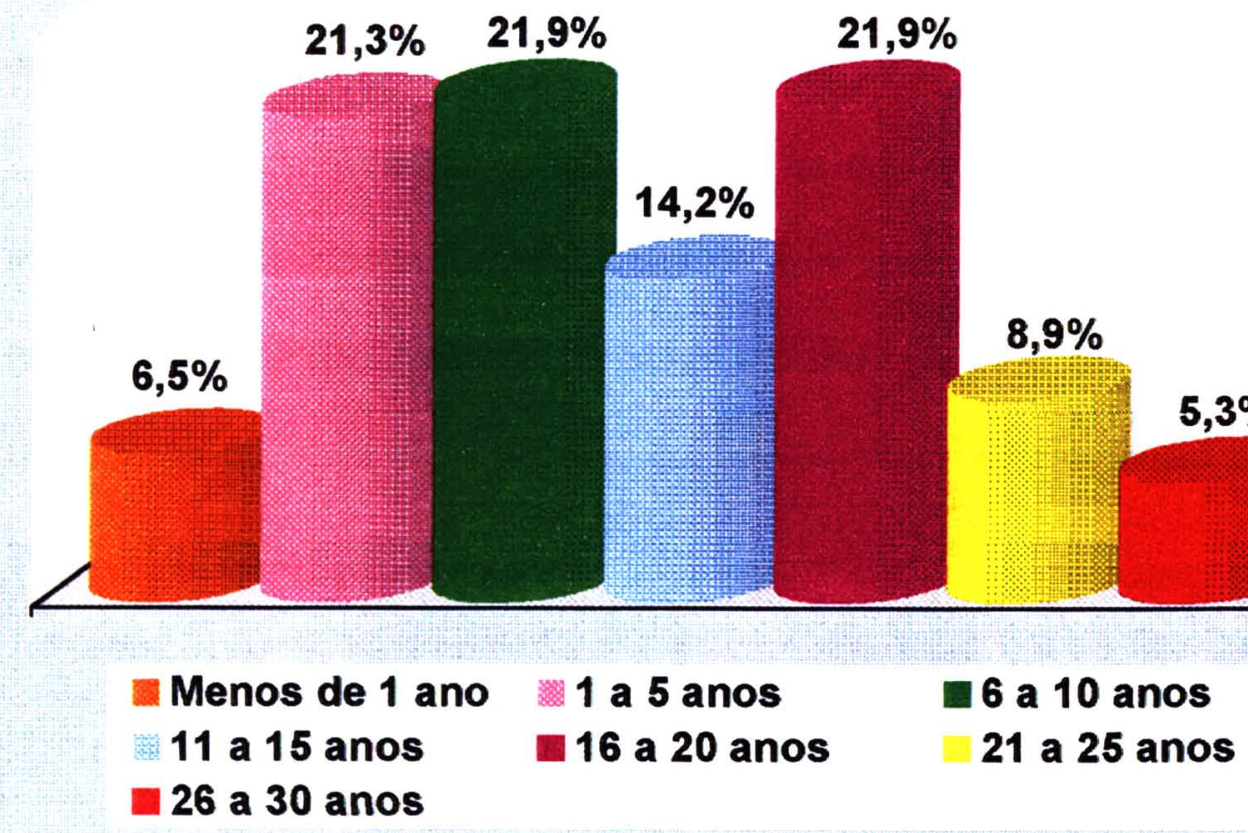

Em $21,4 \%$ dos casos, não foi informado o tempo de trabalho no serviço público. Entre os que informaram, 6,5\% estavam há menos de um ano trabalhando no serviço público, incorporados à rede nos últimos concursos para enfermeiros e médicos; $21,3 \%$ estão entre 1 e 5 anos; encontramos $21,9 \%$ em dois períodos de tempo: entre 6 e 10 anos e 16 e 20 anos; $14,2 \%$ estão entre 11 e 15 anos; $8,9 \%$, entre 21 e $25 ; 5,3 \%$, entre 26 e 30 . O tempo médio de trabalho no serviço público foi de 12,8 anos, o valor mediano foi 12 e o modal foi de 10 anos, revelando certa estabilidade e baixa rotatividade ocupacional nos serviços substitutivos de saúde mental. 


\subsubsection{Trabalhadores universitários e situação profissional}

Quanto à Jornada de Trabalho dos profissionais universitários, considerados em geral, tem-se: $24,7 \%$ trabalham 20 horas semanais, $51,6 \%, 30$ horas semanais e $23,7 \%$ trabalham 40 horas semanais. Entre os que trabalham $20 \mathrm{~h}$, tem-se, em sua maioria, os profissionais médicos, sendo que mais da metade do total destes profissionais trabalha cerca de 30 horas semanais. À $40 \mathrm{~h}$ correspondem, em sua maioria, os diretores das unidades, que muitas vezes desempenham dupla função: gerencial e assistencial.

Figura 9. Distribuição em percentagem dos Trabalhadores Universitários, segundo Jornada de Trabalho. MSP, 2001/2002.

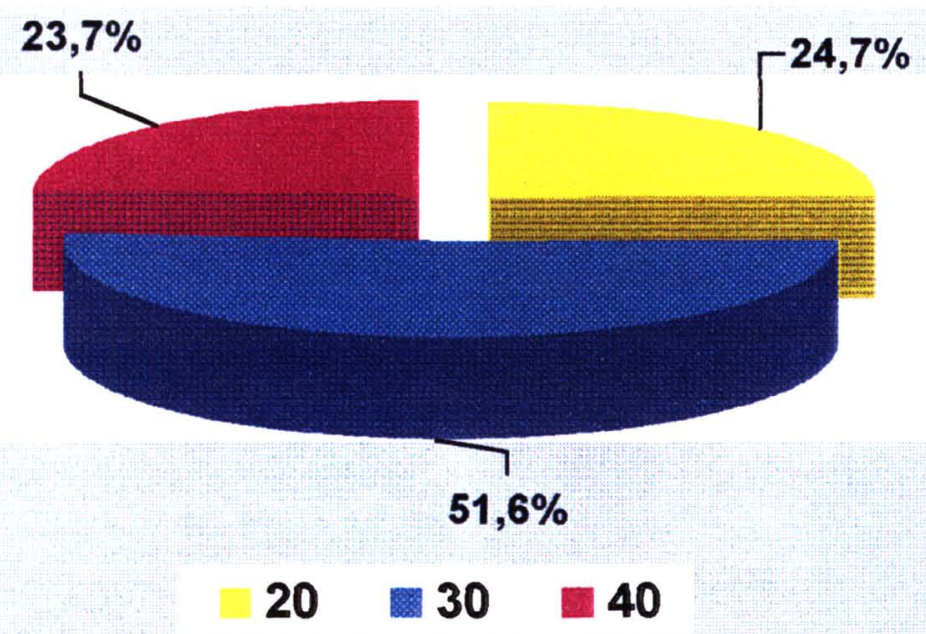


No que se refere ao Vínculo Empregatício, 1,4\% correspondem aos profissionais que foram admitidos pela Prefeitura no início da gestão Erundina e que se tornaram estáveis a partir do quinto ano de contrato; $10,3 \%$ são CLT; $10,3 \%$ foram contratados em caráter emergencial, sobretudo durante o PAS; $54,9 \%$ são efetivos; $4,3 \%$, além de efetivados, possuem outro vínculo com o serviço público; $19,1 \%$ correspondem ao vínculo Lei 500 , modalidade de contratação adotada pelo Estado em 1974, que conferia, após dois anos de exercício profissional, estabilidade aos trabalhadores, universitários e não universitários.

Figura 10. Distribuição em percentagem dos Trabalhadores Universitários, segundo Vínculo Empregaticio. MSP, $2001 / 2002$.

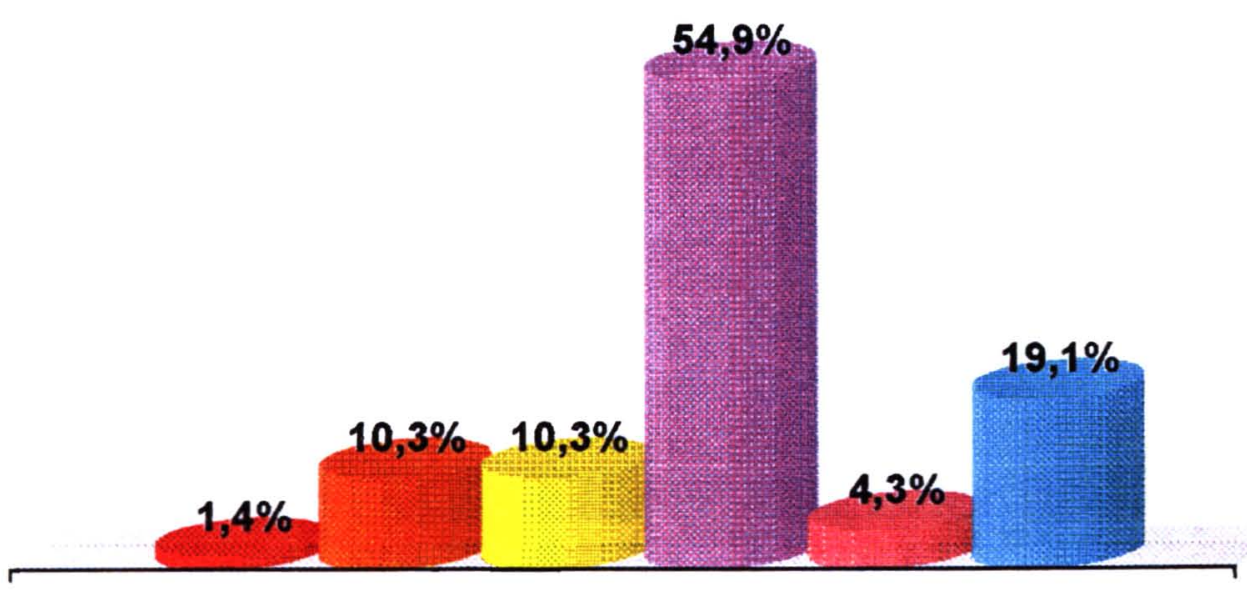

Vínculo empregatício

Admissão $=$ CLT Contrato 
Observa-se, a partir dos dados acima, a tradição do trabalho estável em saúde, formalizado por mecanismos institucionais, em contrapartida a atual tendência do mundo do trabalho de flexibilização da empregabilidade, sobretudo com o processo crescente de terceirização dos setores operacionais, como já discutido do item anterior

Quanto ao tempo de trabalho na unidade atual, no momento da entrevista, tem-se: $18,3 \%$ trabalhavam há menos de 1 ano na unidade atual; $39,1 \%$ trabalhavam entre 1 e 5 anos; $25,4 \%$, entre 6 e 10 anos; $9,6 \%$ entre 11 e 15 anos; $4,6 \%$ entre 16 e 20 anos; $2 \%$, entre 21 e 25 anos e $1 \%$ entre 26 e 30 anos. Os valores mediano e modal foram 10 anos, respectivamente e o tempo médio foi 7,4 anos, com desvio padrão de 5,6 anos 
Figura 11. Distribuição em percentagem dos Trabalhadores Universitários, segundo tempo de trabalho na unidade. MSP, 2001/2002.

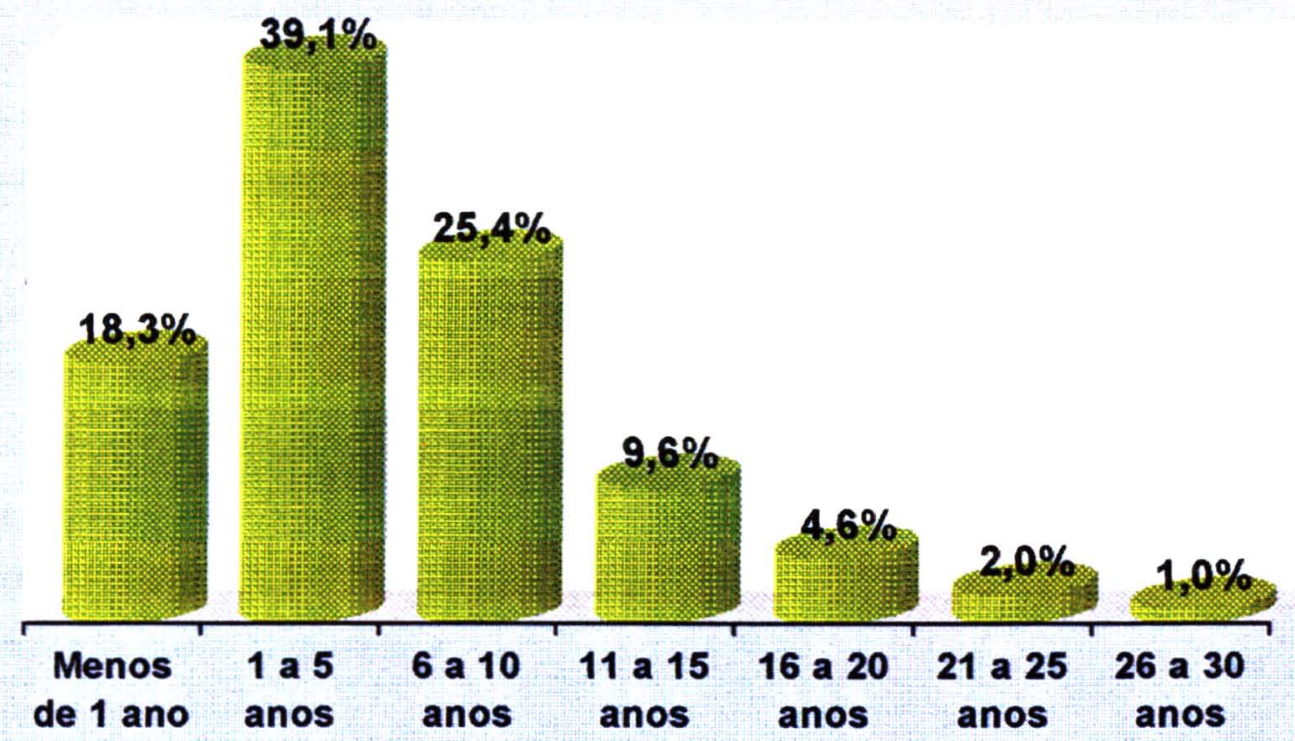


Quanto às especializações dos profissionais, tem-se:

Tabela 5. Areas de especialização dos profissionais universitários. MSP, $2001 / 2002$.

\begin{tabular}{|c|c|c|}
\hline Áreas de Especialização & N. Abs. & $\%$ \\
\hline $\begin{array}{l}\text { Psicanálise, Psicanálise Infantil e } \\
\text { Psicoterapia Psicanalítica } \\
\text { Psicologia Clínica }\end{array}$ & $\begin{array}{l}16 \\
4\end{array}$ & $\begin{array}{c}17,4 \% \\
4,3\end{array}$ \\
\hline Alcool e Drogas & 1 & 1,1 \\
\hline Administração Hospitalar & 4 & 4,3 \\
\hline Pós-Graduação em Recursos Humanos & 1 & 1,1 \\
\hline Cinesiologia & 3 & 3,3 \\
\hline Psicologia Hospitalar & 1 & 1,1 \\
\hline Mestrado em Psicologia Social & 2 & 2,2 \\
\hline Grupo Operativo & 2 & 2,2 \\
\hline Mestrado/Doutorado em Psicologia Clínica & 1 & 1,1 \\
\hline Acompanhamento Terapêutico & 1 & 1,1 \\
\hline Análise Institucional & 2 & 2,2 \\
\hline Coordenação de Grupos & 2 & 2,2 \\
\hline Saúde Pública & 14 & 15,2 \\
\hline Educação em Saúde Pública & 3 & 3,3 \\
\hline Psicopedagogia & 3 & 3,3 \\
\hline Doutorado em Psiquiatria & 1 & 1,1 \\
\hline Farmácia Clínica Hospitalar & 1 & 1,1 \\
\hline Terapia Ocupacional em Saúde Mental & 2 & 2,2 \\
\hline Serviço Social em saúde mental & 2 & 2,2 \\
\hline Mestrado em Educação/Psicologia escolar & 5 & 5,4 \\
\hline Psicodrama & 5 & 5,4 \\
\hline Psicomotricidade & 2 & 2,2 \\
\hline Saúde mental & 8 & 8,7 \\
\hline Terapia familiar & 3 & 3,3 \\
\hline Reabilitação psicossocial & 2 & 2,2 \\
\hline Voztterapia corporal & 3 & 3,3 \\
\hline Total das Mençōes & 92 & 100 \\
\hline
\end{tabular}

Fonte: Pesquisa de Campo; 2001/2002. 


\subsubsection{A situação ocupacional dos diretores das unidades}

Dos 305 profissionais universitários, 27 eram diretores das unidades. Entre estes, 7 são do sexo masculino e 18, feminino. $21 \%$ têm entre 35 e 40 anos de idade; $42,1 \%$, entre 41 e 45 anos; $26,3 \%$, entre 45 e 50 anos e $15,8 \%$, entre 51 anos e mais, sendo que a amplitude de idade variou entre 38 e 59 anos. Entre os homens, 3 são médicos e 4 psicólogos, enquanto que entre as mulheres, tem-se: 1 assistente social e 1 enfermeira: 2 TO's, 4 são médicas e 12 são psicólogas. $59,2 \%$ dos diretores são psicólogos (Tabela 6):

Tabela 6. Categoria profissional dos Diretores das unidades, segundo modalidade assistencial MSP, 2001/2002.

\begin{tabular}{|c|c|c|c|c|c|}
\hline Categoria profissional & \multicolumn{2}{|c|}{ Hospital dia } & \multicolumn{2}{|c|}{ Ambulatório } & Total \\
\hline Assistente social & $\begin{array}{l}1 \\
7,1 \%\end{array}$ & $100 \%$ & $\overline{0}$ & & $\begin{array}{c}1 \\
3,7 \%\end{array}$ \\
\hline Enfermeira & $\begin{array}{l}1 \\
7,1 \%\end{array}$ & $100 \%$ & 0 & & $\begin{array}{c}1 \\
3,7 \%\end{array}$ \\
\hline Médica(o) & $\begin{array}{l}2 \\
14,3 \%\end{array}$ & $28,6 \%$ & $\begin{array}{l}5 \\
38,5 \%\end{array}$ & $71,4 \%$ & $\begin{array}{c}7 \\
25,9 \%\end{array}$ \\
\hline Psicóloga(o) & $\begin{array}{l}9 \\
64,3 \%\end{array}$ & $56,2 \%$ & $\begin{array}{l}7 \\
53,8 \%\end{array}$ & $43,7 \%$ & $\begin{array}{c}16 \\
59,2 \%\end{array}$ \\
\hline Terapeuta ocupacional & $\begin{array}{l}1 \\
50 \% \\
7,1 \%\end{array}$ & & $\begin{array}{l}1 \\
50 \% \\
7,7 \%\end{array}$ & & $\begin{array}{c}2 \\
7,4 \%\end{array}$ \\
\hline Total & 14 & & 13 & & 27 \\
\hline
\end{tabular}

Fonte: Pesquisa de Campo; $2001 / 2002$.

Dentre as especializações dos 14 diretores dos hospitais dia, tem-se 3 menções à psicanálise, 1 para formação em grupo, 3 em saúde pública, 1 mestrado em reabilitação psicossocial, 2 mestrados em psicologia da educação, 1 em psicodrama, 2 
em psicologia clinica, 1 em psicopedagogia. Quanto aos diretores dos ambulatórios, há menções de especialização em psicodrama, psicoterapia, saúde pública saúde mental e análise.

$31,6 \%$ dos diretores e diretoras trabalham na unidade que gerenciam entre $6 \mathrm{e}$ 10 anos; $21 \%$ estão há menos de um ano e outros $21 \%$, entre 1 e 5 anos; $15,8 \%$ estão entre 11 e 15 anos e $10,6 \%$, entre 16 anos e mais.

Quanto à jornada de trabalho, pouco mais da metade trabalha 40 horas semanais $(52,6 \%) ; 42,1 \%, 30$ horas semanais e apenas $5,3 \%, 20$ horas semanais. No que se refere ao vinculo empregatício, $10,5 \%$ foram admitidos ou são CLT, enquanto que $57,9 \%$ são efetivos, $5,3 \%$ foram contratados e $15,8 \%$ correspondem à Lei 500 de 1974, da Secretaria de Estado da Saúde.

Segundo MACHADO E COLS. (1995), no que diz respeito à composição da força de trabalho em saúde no Brasil, ainda há prevalência de médicos em diversas modalidades assistenciais. Entretanto, na última década, é possivel observar crescente aumento do número de profissionais de diversas áreas em todas as modalidades assistenciais, em consonância com as novas formas de gestão da assistência a saúde.

Em termos da saúde mental, encontramos percentuais que expressam a tendência geral da área, observada desde meados dos anos 80 , quando se inicia 0 processo de desinstitucionalização e os psicólogos e outros profissionais da área psicossocial assumem particular relevância para a constituição do quadro de funcionários universitários, correspondendo a $27,5 \%$ do total da força de trabalho em saúde mental, percentual compativel com os dados gerais do país $(25,5 \%)$ (IDEM). 
Os médicos em saúde mental, por sua vez, são psiquiatras, não sendo observada outra especialidade médica nos serviços estudados. A psiquiatria, entre as especialidades médicas, absorveu apenas $2,71 \%$ do total de médicos residentes ( $R 1$ ), no Brasil, no ano de 2001 (OLIVEIRA e MARRONI 2002; p.33).

Quanto à idade, a maior concentração de profissionais ficou entre 31 e 40 anos, o que também corrobora os dados gerais para o setor saúde. Tanto no caso da saúde mental como da saúde, em geral, essa tendència de a força de trabalho em saúde ser jovem se liga ao fato de as demais profissões da área biomédica estarem em franca expansão e do crescente aumento do número de vagas em cursos formadores, cuja média de idade no ano de ingresso é de 20 anos.

A grande maioria dos profissionais pesquisados corresponde à força de trabalho feminina, o que também está em consonância com os dados gerais. No caso da saúde mental, essa concentração feminina também se refere ao aumento dos profissionais da área psicossocial, sobretudo assistentes sociais, fonoaudiólogos e terapeutas ocupacionais.

São poucos os profissionais estudados que trabalham 40 horas semanais. Em geral, esse regime de trabalho corresponde àqueles profissionais que acumulam o cargo de chefia. Os médicos, em sua maioria, trabalham cerca de 20 horas semanais e os demais profissionais, 30 horas e a média do tempo de trabalho nas unidades pesquisadas concentrou-se em torno de 10 anos.

Os profissionais de nivel médio, por sua vez, se distribuem nas atividades administrativas e de assistência, sendo que os auxiliares de enfermagem tiveram uma 
participaçào significativa (42,9\%). A relação entre auxiliares de enfermagem, atendentes e auxiliares técnicos de saúde e profissionais universitários foi de 1:1,8.

Ao se considerarem os serviços, segundo categoria profissional e modalidade assistencial, percebe-se que a distribuição das categorias profissionais é bastante homogênea entre as modalidades, com a única discrepância para a categoria de farmacêuticos, identificados apenas nos ambulatórios, por ocasião da coleta de dados.

A relação entre profissionais da área biomédica (médicos psiquiatras, fonoaudiólogos, enfermeiros e farmacêuticos) e da área psicossocial (psicólogos, assistentes sociais e terapeutas ocupacionais) foi de $1,1: 1$, o que expressa total simetria entre as àreas, o que reflete os preceitos da Reforma Psiquiátrica no que diz respeito ao reconhecimento da necessidade da equipe multiprofissional para a assistência em saúde mental (SES, Op. Cit.). 


\title{
4 \\ Os 'sentidos' do trabalho em saúde mental
}

\begin{abstract}
Diz-se a um cego, Estás livre, abre-se-lhe a porta que o separava do mundo, Vai, estás livre. tornamos a dizer-lhe, e ele não vai. ficou ali parado no meio da rua. ele e os outros. estão assustados, não sabem para onde ir. é que não há comparação entre viver num labirinto racional. como é, por definição, um manicómio, e aventurar-se. sem mão de guia, nem trela de cão. no labirinto dementado da cidade. onde a memória para nada servirá. pois apenas será capaz de mostrar a imagem dos lugares e não os caminhos para lá chegar. Postados diante do edificio que já arde de uma ponta à outra. os cegos sentem na cara as ondas vivas do calor do incêndio. recebem-nas como algo que de certo modo os resguarda, tal como as paredes tinham sido antes. ao mesmo tempo, prisão e segurança. Mantêm-se juntos. apertados uns contra os outros, como um rebanho. nenhum deles quer ser a ovelha perdida porque de antemão sabem que nenhum pasto os irá procurar. O fogo vai decrescendo aos poucos, a lua já ilumina outra vez. os cegos começam a desassossegar-se, não podem continuar ali, Eternamente. disse um deles. Alguém perguntou se era dia ou era noite. a razão da incongruente curiosidade soube-se logo, Quem sabe se não nos virão trazer a comida, pode ter havido uma confusão. um atraso. outras vezes aconteceu. Mas os soldados não estão cá. Isso não quer dizer nada. podem ter-se ido embora por deixarem de ser precisos, Não percebo, Por exemplo. porque deixou de haver contágio, Ou porque se descobriu o remédio para a nossa doença. Era bom, era. Que fazemos. Eu fico aqui até ser dia. E como saberás tu que é dia. Pelo sol. pelo calor do sol, Se o céu não estiver encoberto. Tantas horas hão de passar que alguma vez há de ser dia.
\end{abstract}

José Saramago, Ensaio sobre a cegueira 
Neste capitulo é discutido o trabalho multiprofissional da equipe de saúde mental do Hospital Dia Infantil da Moóca, escolha orientada de acordo com os critérios já enunciados. Para tanto, foram gravadas entrevistas com os profissionais que integram esta equipe e que estavam disponiveis durante o periodo em que aconteceram as entrevistas: 08.10 .02 a 21.02.03.

Os discursos desses profissionais foram considerados como fontes de informação a respeito do cotidiano do trabalho em um serviço intensivo de saúde mental: o histórico do serviço, que coincide com a própria história dos avanços das práticas de saúde mental no Municipio de São Paulo, a concepção e definição da grade de atividades, segundo alguns pressupostos subjetivos e teóricos, a formação diferenciada dos membros da equipe como condição para a realização de um trabalho multiprofissional, a integração e diferenciação desses trabalhos, realizados em parceria ou individualmente, as conexões entre o exercício dessas práticas e as orientações políticas, técnicas e teóricas que embasam o trabalho em saúde mental.

A análise e a interpretação das entrevistas foram direcionadas no sentido de produzirem um relato sobre as representações e percepções que os profissionais têm sobre a sua prática, seu trabalho e também sobre o entendimento acerca do objeto e objetivos da saúde mental atualmente. Buscou-se compreender como essa esfera do trabalho é vivenciada pelos sujeitos entrevistados: os principais problemas e desafios do cotidiano do trabalho em equipe bem como as possiveis soluções. Considerando-se que muitos aspectos que marcam essas relações profissionais são subjetivos, a apreensão da trajetória de formação e profissional de cada um foi reconstituída e 
nestas, os valores que as orientaram; além disso, como cada subjetividade contribui com o coletivo do trabalho.

Um aspecto importante que é ressaltado por todos em unissono é a percepção que têm acerca dos laços profissionais e pessoais que os unem e em que medida, favorecem (ou não) o desenvolvimento de um trabalho de qualidade e integro. Tal integridade na condução do trabalho configura o grau de integração e afinidade que a equipe desenvolveu entre si e com o objeto de sua intervenção ao longo dos anos de trabalho em parceria, em que muitas questões foram repensadas e adaptadas às novas realidades que foram se impondo, como por exemplo, a necessidade de reconhecer que 0 uso dos medicamentos em crianças mais regredidas era imperativo, sem que isso significasse um retomo à política medicamentosa indiscriminada do modelo tradicional.

Mas, se por um lado os profissionais se percebem como equipe multiprofissional, ou interdisciplinar como sempre se denominam, por outro existem alguns aspectos que ainda não estão muito claros nessa percepção.

Os resultados dessa reflexão são apresentados a seguir, e discutidos a partir de alguns temas, revelados pelos discursos e articulados às categorias de análise sugeridas pelos estudos sobre o trabalho em saúde, que constituem os referenciais teóricos adotados.

A equipe de profissionais que participou da segunda fase da pesquisa de campo foi composta por 9 dos 12 integrantes de nivel universitário que trabalham no HDI da Moóca, sendo 8 mulheres e 1 homem Esses profissionais pertencem a diferentes categorias profissionais, já comentadas e reveladas na primeira etapa da 
pesquisa. Para que se tenha uma visão geral do grupo entrevistado e do serviço ao qual se referem, seguem a caracterização do Distrito de Saúde da Moóca, no qual o trabalho da equipe se insere, o perfil da equipe e o histórico do serviço.

\subsection{Tecendo a rede: o Distrito de Saúde da Moóca.}

Como já mencionado, à época da pesquisa de campo o Município de São Paulo estava dividido em 41 e, posteriormente, em 39 Distritos de saúde, para os quais são previstas autonomia gerencial e orçamentária, que visam a coneç̧ão direta com os usuários, de forma regionalizada, por meio das Unidades de Saúde, prestadoras diretas da assistência de saúde em nivel primário e secundário, nas diversas modalidades assistenciais.

No que se refere à rede de serviços de saúde mental, de acordo com as propostas estaduais e nacionais para a política de saúde mental brasileira, a área temática de saúde mental da Prefeitura tem como função elaborar diretrizes locais e criar condições para a implementação dessas diretrizes em nivel local em cooperação com os Distritos de saúde:

"O poder público tem agora a responsabilidade de implantar, no âmbito do Sistema Único de Saúde. uma politica de saúde mental da qual não se espera apenas o desenvolvimento de experiências e modelos a serem expandidos no futuro. mas sim resultados de impacto já no cenário atual. Por essa razão. sempre respeitando a complexidade do sofrimento mental e das formas de se 
lidar com ele. é preciso pensar em soluções que possam ser abrangentes e multiplicadas (SMS Op. Cit.).

Neste sentido, a atual organização da atenção em saúde mental tem considerado as particularidades dos diversos grupos populacionais, destacando os fatores de vulnerabilidade de cada grupo para o desenvolvimento dos transtomos mentais, passando a instrumentalizar a rede básica na deteç̧ão dessas afeç̧ões e sensibilizar os diversos profissionais no tocante aos procedimentos subseqüentes mais adequados, dado que as queixas psíquicas parecem ser das causas mais freqüentes de procura por atendimento na atenção básica. Dados epidemiológicos brasileiros revelaram elevada prevalência de transtornos mentais entre os que procuram a atenção básica: $35,5 \%$. Deste total, $15,8 \%$ correspondem a transtornos depressivos, $22,6 \%$ à ansiedade generalizada e 4,1\% a alcoolismo, entre outras (BALTIERI e ANDRADE 2002).

Partindo, pois, dos preceitos da promoção, prevenção, tratamento e reabilitação, e que um conjunto de novas ações e serviços estão sendo instituidos, assim como antigos projetos e programas incentivados e/ou remodelados, como o caso dos Centros de Atenção Psicossocial, que devem ser regulamentados em três niveis de complexidade: CAPS infantil e CAPS álcool e drogas, conforme portaria do Ministério da Saúde 336/02, e CAPS III, correspondendo a um novo modelo de atenção intensiva a ser incorporado à rede especializada, contarão com poucos leitos de curta permanència (MS 2002). 
Devem, ainda, ser incorporados à rede de serviços paulista de atenção à saúde mental programas como leitos em centros de atenção comunitária e residências terapêuticas, para facilitarem o trânsito social desses pacientes e serviços de emergência psiquiátrica e leitos para internação de pacientes em crise em hospital geral (SMS Op. Cit.).

O Distrito de Saúde da Moóca compreende os bairros do Belenzinho, Tatuapé e Moóca e sub-regiões (Figura 12). Margeado por grandes avenidas, como a Celso Garcia e Paes de Barros, o Distrito conta com boa rede de comércio e infra-estrutura urbana, escolas e faculdades privadas bem como uma série de serviços públicos.

Quanto aos serviços de saúde mental, o Distrito conta com emergência psiquiátrica em pronto-socorro; equipes mínimas de saúde mental em ambulatório de especialidades, em duas unidades básicas de saúde e em dois centros de saúde; 1 CRI (Centro de Referência Infantil), 1 CRST (Centro de Referência do Trabalhador - da Moóca), 1 HDI (Hospital Dia Infantil em Saúde Mental da Moóca) e 1 Ambulatório de Saúde Mental - do Belenzinho (Figura 13). 


\section{Distrito de Saúde Móoca}

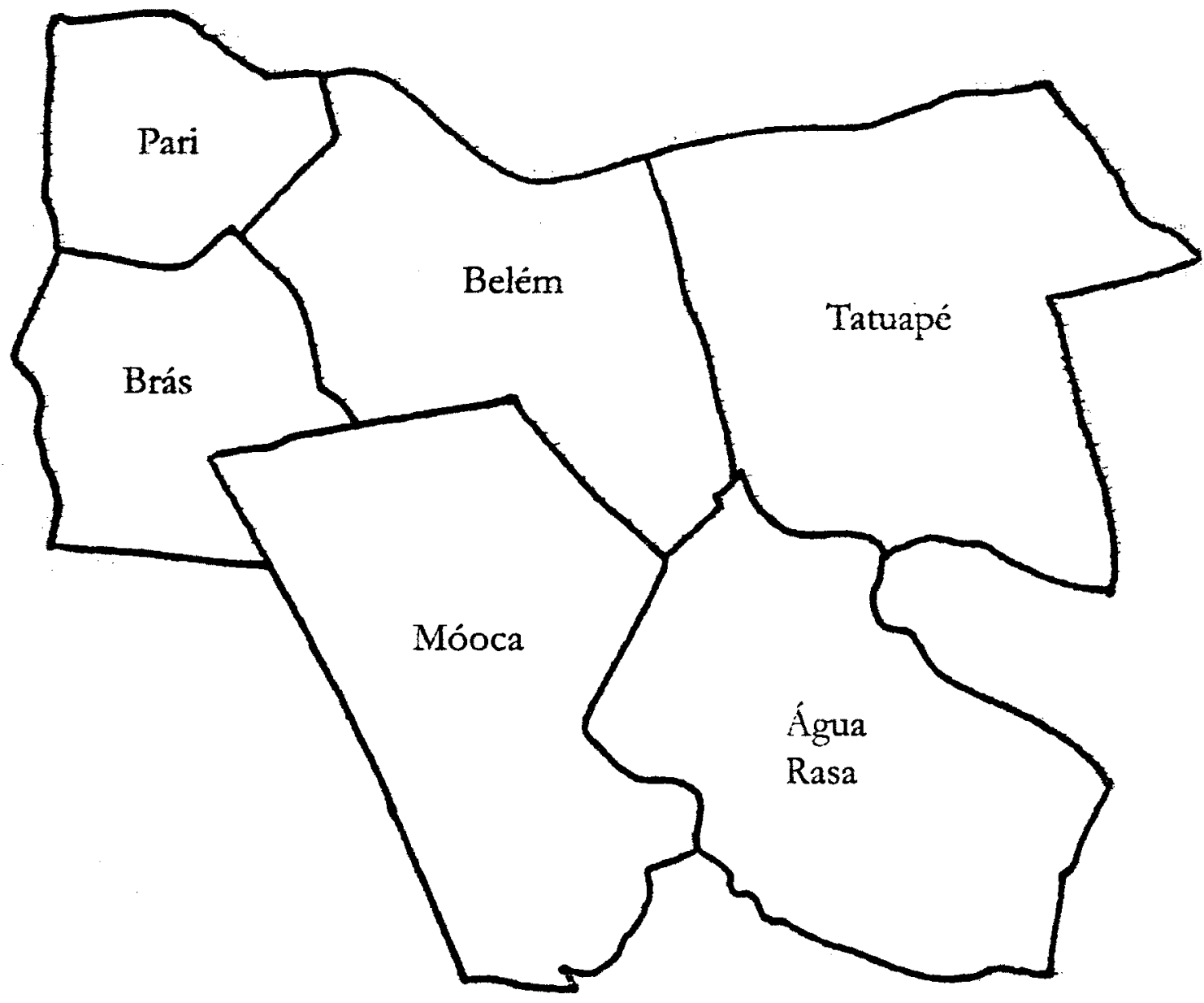

Fonte: CEM - Centro de Estudos da Metrópole

CEBRAP - Centro Bras. de Análise e Planejamento

Elaboração: Marcel Pedroso

Reelaboração: Silvana Maria de Souza 


\section{Distrito de Saúde Móoca}

\section{Distribuição dos Equipamentos de \\ Saúde Mental}

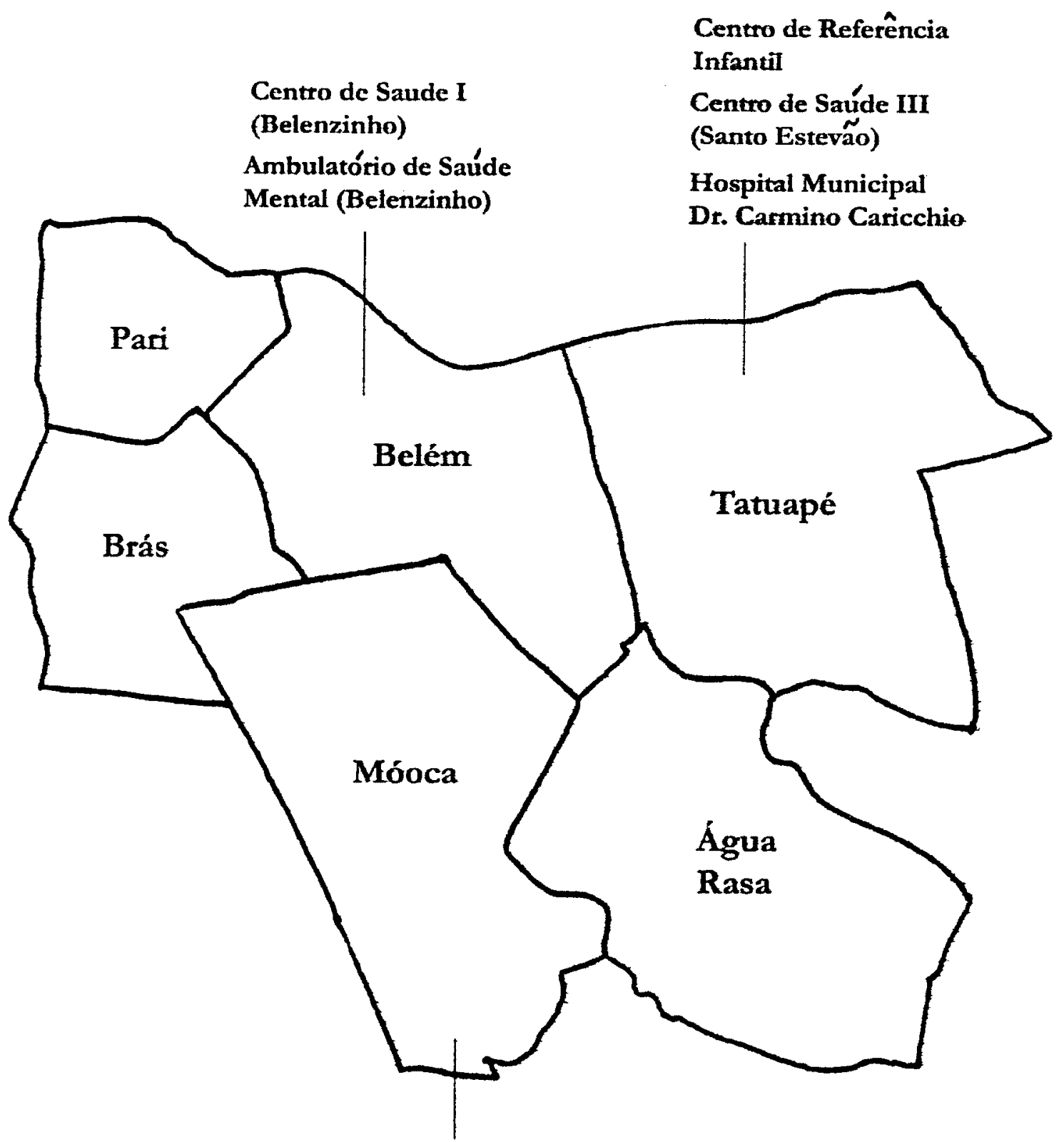

Ambulatório de Especialidades

Dr. Ítalo Vocci

Unidade Básica de e Unidade Básica de

Saúde (Mooca I) e Saúde (Vl.Bertioga)

Centro de Referência

em Saúde do Trabalhador

Hospital Dia Infantil

em Saúde Mental 


\subsection{Por 'uma experiência democrática brasileira': caracterização do Hospital Dia Infantil em Saúde Mental da Moóca e de seus profissionais}

O Hospital Dia em Saúde Mental Infantil da Moóca foi inaugurado em janeiro de 1992, na gestão de Luiza Erundina, na esteira do movimento antimanicomial dos anos 80 , juntamente com outros serviços alternativos, tais como os hospitais dia de adultos e centros de convivência e cooperativas:

“(..) Em 1990, já desde 89 com a entrada da Luiza Erundina como prefeita pelo PT. nós conseguimos que a saúde mental fosse valorizada de um outro modo e que realmente se criassem instituições que sejam de fato alternativas para o tratamento de saúde mental. que chegue a requerer internações. Com isso. nós conseguimos naquela época uma implantação de diversos serviços de HD's de adultos, com emergências psiquiátricas e leitos em Hospitais Gerais e Centros de Convivência que compusessem essa rede e nisso surgiram também HD's infantis. em número muito menor que o de adultos. mas que também dessem conta dessas situações tão graves e que evitasse que se tornassem os futuros adultos psiquiatrizados crônicos". (PSIMR)

Desde sua inauguração, houve esforços para a organização do serviço e a equipe inicial, egressa de outras experiências alternativas e da militância no movimento antimanicomial, trabalhou na concep̧̧ão daquilo que seria $o$ atendimento em saúde mental para crianças com transtornos mentais e de desenvolvimento: 
“(...) eram algumas pessoas que já tinham algum tipo de experiência anterior. Na época. dois colegas traziam a experiência em comunidades terapêuticas. Nós fomos trazendo essa troca e começamos a implantar pouco a pouco. recebendo crianças com outros diagnósticos. com os quadros mais proximos dos que a gente trata hoje. e começamos a formar uma grade de atividades. Sem nenhuma experiência, nós começamos a buscar as experiências relatadas na literatura francesa com os ateliês, na literatura italiana com toda a psiquiatria democrática de Bazaglia. fomos fazendo uma experiência democrática brasileira, cada um entrando com o que sabia". (PSIMR)

No prédio em que funciona atualmente o HDI existia uma Clínica de Saúde do Escolar, serviço que foi extinto com a gestão de Erundina, e esta transição foi acompanhada por uma crise que envolveu técnicos do antigo serviço, familiares e profissionais ligados a outras Secretaria, que também disputavam o local, pois trata-se de uma estrutura arquitetônica privilegiada: uma construção térrea bastante ampla, com um pátio grande e arborizado e uma localização relativamente centralizada, próximo de outros equipamentos de saúde e educação e de estação de metrô. Mas, como a idèia era que se mantivesse o atendimento voltado para crianças, algumas das quais já atendidas pela Clinica de Saúde Escolar, a proposta do HDI prevaleceu:

..... na gestão da Erundina, havia (...) a idéia de que a fonoaudióloga não deveria ser algo especifico da educação, a fono escolar, o ideal seria: a fonoaudiologia começa a ser entendida como um profissional da saude que 
deveria dar suporte às outras redes. (...) acabou se pensando em extinguir as Clínicas de Saúde Escolar. foi uma briga, (...) mas eram muitas crianças com (...) distúrbio de aprendizagem, de leitura escrita, mas um nümero grande também de casos que nós atendiamos fazendo um atendimento familiar com a psiquiatra que bancava isso, (...) e foi a clínica que mais resistiu à extinção. tanto que esse prédio era prometido para a saude do trabalhador e todos os fonoaudiólogos e psicólogos iam ser transferidos para UBS, então como nós mostramos essa nossa vontade de fazer um trabalho diferenciado. (...) se pensou num projeto infantil, porque algumas crianças (..) realmente era dificil a rede estar absorvendo. (...) tinham alguns autistas. (..) os pais estavam valorizando esse trabalho. (..) era cara de criança mesmo. foi tudo feito para a demanda mais infantil, então se pensou em fazer o HDI. (...) e até absorver casos que já estavam, dando continuidade (...)" (FONOM)

Naquele momento, parecia dificil adaptar para crianças a proposta de hospital dia, cujo objetivo essencial é:

“(..) acolhe na crise e não desliga da familia. É que a crise na infância ela é muito diversa da crise no adulto ou na adolescência mesmo. então é muito rara esta situação, mas o primeiro objetivo da Instituição é promover o desenvolvimento e recuperar ou promover a socialização dessas crianças com esse grau de comprometimento e dar acolhimento nas crises que ocorram." (PSIMR) 
Esta equipe esteve junta até a gestão Paulo Maluf, quando alguns profissionais foram substituídos e em 1996, com a implantação do PAS (Plano de Atenção à Saúde), já na gestão Celso Pitta, a saúde mental voltou a ter um caráter eminentemente patológico e institucionalizante e todos os profissionais se afastaram. Em 2001, com a entrada de Marta Suplicy no governo municipal, houve a retomada das propostas anteriores, da Reforma Psiquiátrica e implantação do Sistema Único de Saúde. Portanto, é no contexto institucional da municipalização da saúde, na cidade de São Paulo, que ainda não chegou a seu termo e, segundo os depoimentos, ainda não se fez sentir no cotidiano do trabalho, que parte importante da equipe inicial retorna ao HDI.

Em geral, os entrevistados possuem uma visão um tanto negativa do que foi e mesmo do que ainda está sendo esse processo, e se este não os afetou negativamente, também não os beneficiou:

“(..) do jeito que ela foi, do jeito que ela está, é lamentável, porque. na realidade, é uma desobrigação (...) a gente discutiu muito a municipalização na época da Erundina. e gente colocava: 'nós não queremos municipalizar se não for integrado e se não tiver a garantia de repasse de verba, integral'. não é só municipalizar os centros de saude. e os hospitais? Porque se municipaliza só a rede. os hospitais não, o hospital é muito independente, decide o que bem entende (...). Tem todos os princípios (do SUS), que estão sendo desrespeitados e o Estado... é aquilo que a gente falou. (...) há uma desobrigação com a saúde. na verdade, então está muito triste e acho que não tem uma articulação com a população, com os funcionários. e as coisas estão vindo muito prontas, 
tem as demandas e corre-se para apagar o fogo. então. neste sentido. $\dot{e}$ lamentavel. Os Conselhos Estadual e Municipal são mais figuras decorativas. são muito coptados, estão lá para dizer sim ao que a administração aponta como prioridade. O Orçamento participativo? Eu acho o fim, e olha que eu sou filiada ao PT, mas tenho uma critica muito grande. Eu falei assim: 'nossa. primeiro orçamento participativo e o pessoal já está defendendo o PSF?', você entendeu? Saiu como prioridade dois o PSF. mas não sabiam nem o que era. então na verdade, acaba utilizando aquele espaço, as associações $e$ as organizações para pôr o que é a prioridade da administração, não do que é, de fato. uma necessidade dos trabalhadores, da população. Não acho que com isso eles estão sendo sacanas. não é isso. mas estão sendo extremamente antidemocráticos. porque tem gente que acredita muito no Conselho Municipal, Estadual. orçamento participativo, (...) acredita e faz; eu já tenho uma visão muito critica de tudo isso, (...) Como a administração é petista, sempre é uma dificuldade de lidar, porque ao invés de ir com a reivindicação no seu todo, não. pede-se menos, então vai tirando a autonomia, a independência disso e vai ficando muito colado com essa administração. Poxa vida. mas continua a mesma coisa! Então a população: 'ah, tá bom!'. tem demanda de 50, mas tem que priorizar 10. já vai com esse espirito (...) e ai acomoda. não organiza para lutar por essas reivindicações. 'aonde está o dinheiro?, nosso dinheiro é para isso e podemos gastar só isso' e o pessoal fica lá gastando toda a energia para definir os dez entre a associação e as entidades... é um absurdo. é um absurdo. mas depende como você conduz isso, agora se você conduz: 'por enquanto. 
temos isso. isso e isso. não tem dinheiro, o que a gente faz? : ai você vai dar opção da população se mobilizar, se organizar (...)" (ENFEN)

A citação acima representa bem o sentimento comum em relação ao modo como foi, inicialmente, conduzido o processo de municipalização da saúde, em São Paulo, pois não obstante ter sido um dos pilares da gestão Eduardo Jorge, parece que alguns setores e programas foram priorizados ou melhor discutidos e trabalhados junto aos serviços e profissionais diretamente interessados, como é o caso do Programa de Saúde da Familia. Ao expressarem distanciamento destas questões, revelam certo rechaço a tais encaminhamentos políticos, como se não estivessem, de alguma forma também implicados neste processo, com o qual parecem não compartilharem responsabilidades e compromissos; por outro lado, pode indicar que a saúde mental ainda é "uma ilha", com dificuldades de se integrar e ser integrada à rede de serviços.

De todo o modo, são estes profissionais que aqui estavam antes do PAS e outros, incorporados à equipe nos últimos anos da gestão Erundina ou mesmo agora, em 2001, cujos relatos integram a narrativa sobre o trabalho coletivo em saúde mental e sobre os quais apresenta-se uma primeira aproximação (Quadro 2): 
Quadro 2. Profissionais Universitários do HDI da Moóca, segundo situação ocupacional. MSP, 2001/2002.

\begin{tabular}{|c|c|c|c|c|}
\hline Nome & $\begin{array}{c}\text { Categoria } \\
\text { Profissional }\end{array}$ & $\begin{array}{c}\text { Jornada } \\
\text { de } \\
\text { Trabalho } \\
\text { (semanal) }\end{array}$ & $\begin{array}{c}\text { Vinculo } \\
\text { Empregaticio }\end{array}$ & $\begin{array}{c}\text { Tempo de } \\
\text { Trabalho } \\
\text { na Unidade }\end{array}$ \\
\hline Márcia Ramos & $\begin{array}{l}\text { Psicóloga e diretora } \\
\text { da unidade }\end{array}$ & 40 & Efetiva & 11 anos** \\
\hline Jorge F. Maalouf & $\begin{array}{l}\text { Psicólogo e auxiliar } \\
\text { de direção }\end{array}$ & 40 & Efetivo & 10 anos $^{* *}$ \\
\hline Mira Wajntal* & Psicóloga & 40 & Efetiva & 10 anos $^{* *}$ \\
\hline $\begin{array}{l}\text { Maria do Carmo } \\
\text { Breda Sartorelli }\end{array}$ & Médica Psiquiatra & 20 & Efetiva & 10 anos $^{* *}$ \\
\hline $\begin{array}{ll}\text { Anunciação de } \\
\text { Souza Pasin* }\end{array}$ & Médica Psiquiatra & 20 & Efetiva & 6 meses \\
\hline $\begin{array}{l}\text { Márcia } \\
\text { Innocêncio }\end{array}$ & $\begin{array}{l}\text { Terapeuta } \\
\text { ocupacional } \\
\end{array}$ & 40 & Efetiva & 6 meses \\
\hline $\begin{array}{lcc}\text { Marici } & \text { T. } & \text { A. } \\
\text { Matos Fenga } & \\
\end{array}$ & Fonoaudióloga & 40 & Efetiva & 9 anos $^{* *}$ \\
\hline $\begin{array}{l}\text { Liege Christina } \\
\text { Simões Campos }\end{array}$ & Fonoaudióloga & 40 & Efetiva & 10 anos $^{* *}$ \\
\hline $\begin{array}{ll}\text { Eliane } & \text { Silva } \\
\text { Rodrigues } & \\
\end{array}$ & Enfermeira & 30 & Efetiva & $10 \operatorname{anos}^{* *}$ \\
\hline $\begin{array}{l}\text { Neusa de Jesus } \\
\text { Duque }\end{array}$ & Enfermeira & 30 & Efetiva & $9 \operatorname{anos}^{* *}$ \\
\hline $\begin{array}{l}\text { Glória de Jesus } \\
\text { Fernandes* }\end{array}$ & Assistente Social & 40 & Efetiva & 11 anos** \\
\hline $\begin{array}{l}\text { Ana Maria } \\
\text { Romagnoli }\end{array}$ & Assistente Social & 30 & Efetiva & 6 meses \\
\hline
\end{tabular}

* Estes profissionais não foram entrevistados, porque não estavam disponiveis no periodo de realização das entrevistas.

** O tempo de trabalho na unidade para estes profissionais è compativel com o tempo de funcionamento do HDI desde sua inauguração, sendo que entre os anos de 1996 e 2000 estiveram afastados do serviço por conta do PAS.

Fonte: Pesquisa de Campo; 2001/2002.

Os profissionais de nivel mèdio, por sua vez, não foram considerados na presente análise por questões teóricas, como exposto anteriormente, mas vale à pena registrar que sua participação no cotidiano do trabalho, na relação com as crianças e com os pais, têm-se mostrado de grande importância, segundo referiram os técnicos 
entrevistados, denominando-os também como "verdadeiros agentes de saúde mental", por sua habilidade, envolvimento e composição no trabalho. A partir de setembro de 2002, com o concurso para auxiliares de enfermagem, passaram a compor o quadro de funcionários de nivel médio do HDI: 1 vigia e 1 profissional da limpeza (terceirizados), 1 oficial de serviços gerais, 2 agentes administrativos e 5 auxiliares de enfermagem.

A unidade atende a crianças de várias regiões da cidade, pois existiam, até bem pouco tempo, apenas quatro unidades específicas para atender a essa demanda e o HDI da Moóca é referência neste tipo de atendimento. No final do ano anterior, entretanto, alguns hospitais dia adulto passaram a atender a crianças e adolescentes, como o caso dos antigos HD de Itaquera, razão pela qual passou a ser o Centro de Referência da Infância e Adolescência em Itaquera, o HD do Jabaquara, que passou a atender crianças, e o antigo Ambulatório de Saúde Mental de Santo Amaro que, com a municipalização, passou para HD de Juventude:

“(...) Hoje, atualmente um Distrito de saúde deveria dar contar de 250 mil habitantes, e um HD ele dá conta de, pelo menos, 4 distritos teoricamente, na prática nós estamos dando conta de um terço da cidade".(PSIMR)

Em termos da formalização da divisão das tarefas do HDI, existe um organograma interno, de acordo com o padrão de lotação da Secretaria da Saúde:

“(...) nós temos os operacionais, nivel médio e nivel universitário. Isso iniciando por ai que a grosso modo, é uma divisão. De outro modo. no nosso organograma da instituição mesmo. todos os que estão aqui dentro. desde o 
vigia que é terceirizado, desde o pessoal da faxina que é terceirizado. uma funcionária de nivel operacional que fica na cozinha. duas de nivel médio que são escriturárias e os demais são ou nivel médio. técnicos e auxiliares de enfermagem e o nivel universitário são todos, de ponta a ponta. são considerados agentes de saúde mental. Existe uma divisão de tarefas onde alguns respondem por setores mais definidos, então eu como chefia e o Jorge. auxiliar de chefia, respondemos pela parte administrativa e direção clinica. Existem aqueles que se responsabilizam mais pelo andamento do setor de grupos de famílias. Existe a médica que se responsabiliza, inclusive frente ao CRM, como a técnica responsável de uma Instituição de Saúde. não é uma chefia médica. Eu sou psicóloga. E temos uma outra formalização que é a Comissão de Ensino e Pesquisa da unidade..." (PSIMR)

Como o trabalho prestado pelo HDI da Moóca é voltado estritamente para crianças com psicoses precoces e autismos, considerando a dinâmica familiar que integram, foi necessário estabelecer vínculos também com os pais dessas crianças, embora o HDI não os atenda diretamente. Nesse sentido, a grade de atividades contempla atendimentos psicoterapêuticos conjuntos (com familiares e crianças juntas), atendimentos de apoio a familiares, psicoterapia e atendimento fonoaudiológico individuais; oficinas terapêuticas (de estórias, de música, do movimento, espaço livre, estimulação), que são atendimentos grupalizados, realizados em parceria, de acordo com as afinidades e habilidades de cada um e da dinâmica de trabalho em grupo e concepção que estabeleceram; atividades extra muros e 
intersecretariais, como a inclusão escolar e a oficina cultural, realizadas também em grupo, no sentido de envolver a familia, a escola e a comunidade do entorno na socialização dessas crianças; e os trabalhos de intervenção precoce, voltados para crianças a partir de idades menores, e o diagnóstico, realizado em geral em dupla, por médicos e não médicos. As atividades administrativas e operacionais correspondem ao expediente, cozinha, faxina, segurança e manutenção.

O fluxo do paciente no HDI começa pela triagem de casos encaminhados, juntamente com relatórios, de preferência de outro profissional da saúde mental da rede de saúde ou mesmo de outras instituições, como por exemplo, de escolas em que os professores conheçam o trabalho e os profissionais do HDI. É feita uma avaliação, onde são identificados os casos que são para o HDI, e os demais são novamente encaminhados. Este diagnóstico é realizado por psiquiatras ou em parceria (psiquiatra e outro profissional), mas sempre conta com a retaguarda dos demais profissionais. Correspondendo a casos de psicoses precoces ou autismos, ou mesmo estando em crise, recebem a assistência e são incluídos no atendimento intensivo, ou seja, em hospital dia e participam das oficinas terapêuticas, de acordo com suas condições no momento, e a familia é encaminhada para o grupo de familiares, de cunho interpretativo, em que se faz o atendimento ao núcleo familiar e, caso necessário, atendimento individual terapêutico. Dentre as crianças, aquelas que apresentam condições são, também, encaminhadas para uma classe especial na escola, através do trabalho de inclusão escolar e o contato é direto com o professor, pois o ideal é que essas crianças freqüentem a escola. 
Nos últimos tempos, a demanda atendida pelo HDI chegou a 60 crianças, cerca da metade atendida na modalidade ambulatorial. São crianças menos regredidas, mais estáveis, cujo quadro pode ser "controlado" pela família e pela escola. Entre as que estão no acompanhamento intensivo, em torno de 16 crianças freqüentam o HDI no período da manhã e 16 no periodo da tarde, duas vezes por semana. Às sextasfeiras são realizadas as reuniões de equipe por periodo e uma no intervalo dos turnos, em que se discutem todos os assuntos referentes ao trabalho com os pacientes, ocasião em que também são discutidos aspectos da própria dinâmica da equipe.

\subsection{Dos saberes às práticas: formação e trajetória profissional na construção do 'olhar'}

A formação acadêmica dos entrevistados e sua trajetória profissional fornecem pistas interessantes que contribuem para a análise a respeito de suas concepções sobre - trabalho que desenvolvem no HDI e permitem identificar os caminhos que nortearam suas escolhas e opções profissionais e teóricas e em que medida essas escolhas contribuíram com as representações e percepções que têm hoje do trabalho em saúde mental.

À exceção da diretora da Unidade, cuja entrevista teve um cunho mais gerencial e político, fornecendo uma panorama geral do serviço, das atividades, do trabalho e da própria história da saúde mental em São Paulo, da qual ela e os demais profissionais fazem parte, os entrevistados foram convidados a falar sobre aspectos de sua formação, como o curso, o periodo e local em que realizaram a graduação. 
No que se refere à época em que estes profissionais fizeram a graduação, temos: a assistente social, Ana Maria, que estudou entre 1974 e 1977 na FMU Faculdades Metropolitanas Unidas -; a psiquiatra, Maria do Carmo, entre 1979 e 1984, na Faculdade de Medicina da Universidade de São Paulo, na cidade de Ribeirão Preto; a fonoaudióloga Liege, entre 1979 e 1982, graduada pela Escola Paulista de Medicina - Universidade Federal Paulista; as enfermeiras Eliane e Neusa, entre 1982 e 1985, formadas pela Escola de Enfermagem da Universidade de São Paulo e Pontificia Universidade Católica de São Paulo - campus de Sorocaba, respectivamente; o psicólogo Jorge, que estudou na Pontificia Universidade Católica de São Paulo, campus da capital paulista, nos anos 1983 a 1987; a fonoaudióloga Marici, que também estudou na Pontificia Universidade Católica de São Paulo e a terapeuta ocupacional, Márcia Innocêncio, formada pela Universidade Federal de São Carlos, ambas entre os anos 1984 e 1987.

O periodo da formação básica dos entrevistados compreende, portanto, meados dos anos 70 até final dos anos 80 , que, como discutido anteriormente, representam momentos importantes para o campo da saúde pública brasileira, de modo geral e para a saúde mental em São Paulo, em particular. Corresponde ao periodo em que foi deflagrada uma grande crise social e política no pais, refletidas de forma dramática na saúde, engendrando a transição democrática que seria acompanhada por um processo lento de mudanças nas concepções e diretrizes das politicas de saúde.

Quanto às escolas formadoras, pode-se dizer que estes profissionais estudaram nas melhores ou, pelo menos, mais tradicionais escolas do pais. Se é possivel associar 
a história do ensino da medicina e da enfermagem em São Paulo à USP e à Escola Paulista de Medicina, o mesmo acontece com a trajetória do ensino da psicologia, do serviço social e da fonoaudiologia e a PUCSP, entretanto as demais instituições referidas também desfrutam de prestígio no âmbito do ensino superior brasileiro, público e privado, por indicarem filiações teóricas e ideológicas importantes.

No tocante às áreas de especialização, as duas enfermeiras realizaram formação em saúde pública na Faculdade de Saúde Pública da USP; a TO e a psiquiatra aprimoramento e residência em psiquiatria geral no Hospital das Clínicas de Ribeirão Preto, respectivamente, além de a primeira ter feito coordenação de grupos e análise institucional e uma especialização especifica de terapia ocupacional na Escola Paulista de Medicina e a segunda, formação em Psicanálise no Sedes Sapientiae, contemporaneamente à diretora da Unidade. A fonoaudióloga Liege fez especialização em audiologia clínica e otoneurologia também na Escola Paulista e mestrado em psicologia social no Instituto de Psicologia da USP, assim como o psicólogo Jorge, que também se voltou para a carreira acadêmica, com o mestrado e doutorado em psicologia clínica na PUCSP, além de aprimoramento e especialização em atendimento a adolescentes. A fonoaudióloga Marici e a assistente social Ana Maria fizeram estágios extracurriculares durante a graduação e cursos livres, nas suas áreas de atuação, promovidos pela Prefeitura.

Nesse trânsito dos entrevistados rumo à formação, estendida nos anos 90 , revelam-se caminhos comuns, seguidos em momentos diferentes, mas que já apontavam certa "afinidade intuitiva" entre o grupo, e que expressam, como pude notar na primeira fase da pesquisa ao conversar com os diretores das unidades, a 
constituição da "rede de relaçð̃es" (profissionais e pessoais) que configura o trabalho em saúde mental no Municipio de São Paulo.

A seguir, encontra-se uma reflexão acerca da constituição das áreas profissionais que compõem o trabalho em saúde mental, localizando nestes breves históricos os percursos dos sujeitos entrevistados.

\subsubsection{Aspectos da constituição do serviço social como prática de saúde: em busca de um lugar ao sol}

Em São Paulo, é nos anos 30 que se localizam as primeiras práticas do serviço social voltadas para a saúde, em um conjunto de ações sociais que visavam estimular a prevenção de doenças comuns à época, como a tuberculose, lepra e sífilis, junto a creches, asilos e hospitais e outras instituições, que correspondiam às obras sociais da burguesa filantropia brasileira, cujas raizes remontam ao periodo colonial, e dos setores conservadores da Igreja Católica, que criaram os Centros de Estudos e Ação Social de São Paulo para instrumentalizarem tecnicamente os agentes que estariam desenvolvendo este trabalho de assistência social (PALMA, Op. Cit.).

Com a criação do Departamento de Assistência Social do Estado, iniciou-se um processo de incorporação desses agentes junto à assistência médica, sobretudo pelas instituições atreladas à Previdência Social, impulsionando a formação de novo mercado de trabalho. Mesmo estando a formação deste contingente de trabalhadores ainda fortemente ligada à doutrina católica, suas práticas foram sofrendo mudanças e 
se articulando a outras práticas e doutrinas teóricas, pois o contexto político do periodo facilitava tal movimento.

Antecipando à própria formalização do ensino do serviço social e à oficialização de seu exercicio profissional, as atividades que esses agentes passaram a desenvolver foram se complexizando, destacando-se a triagem de individuos e familias para a concessão de auxilios financeiros e previdenciários, encaminhamentos para serviços médicos e internações em instituições públicas e filantrópicas, colocação profissional, regularização de documentação, entre outras. Em função disso, a formação técnica foi se especializando e culminou na criação, em 1936, da Escola de Serviço Social. (PUC Op. Cit.).

Nas décadas seguintes, o serviço social foi-se institucionalizando e esteve direcionado às necessidades dos trabalhadores de diversos setores da economia, especialmente os da indústria, ampliando seu projeto de intervenção na "miséria", cada vez mais de acordo com a perspectiva da proteção social, e o trabalho a ela dispensado comprometido cada vez mais com a concessão de auxilios, sem autonomia e aquém dos limites da cidadania.

Numa tentativa de ruptura com esse modelo, já no final da década de 60 , inicia-se o chamado Movimento de Reconceituação, que contou com a participação efetiva de segmentos organizados da categoria dos assistentes sociais, quando a especificidade do serviço social como trabalho social e como tecnologia de assistência começa a ser questionada. Ao rumar para campos mais específicos dentro da saúde, por exemplo, os assistentes sociais deparam-se com demandas mais complexas e com a inadequação de seu objeto de conhecimento aos novos objetos de intervenção. E, 
sobretudo, encontram resistências à mudança de paradigma de alguns setores, comprometidos com as práticas conservadoras, como a própria saúde pública brasileira Desta forma:

"a história da inserção do profissional dos assistentes sociais. hegemonicamente na área da saúde e dentro dela na atenção terciária. mostra que o Serviço Social acompanhou a tendência da medicina no Brasil: o desenvolvimento e consolidação de uma medicina curativa calcada no modelo clínico-assistencial com a conseqüente priorização de construção $e$ manutenção de unidades de atenção terciária - os hospitais - e o descaso com as unidades de atenção primária" (VASCONCELOS 2002; p. 90).

Nesse embate, o reconhecimento da necessidade de autonomia profissional por uns, como condição ao exercício da cidadania dos próprios profissionais e tambẻm daqueles que atendem, deflagra o debate sobre a qualidade e as condições de formação desse profissional, que esteve pautada por uma divisão clara entre teoria e prática, favorecendo a formação de um quadro técnico, ainda defendido por muitos:

"O direito de criticar e enfrentar a realidade com autonomia não é negado ao assistentes sociais por 'outros' - instituição, profissionais, realidade como freqüentemente é apontado pelos profissionais ao lamentarem os empecilhos postos na atuação profissional. É um direito que os próprios assistentes sociais se negam, alimentando sua própria subalternidade ao não realimentarem permanentemente sua formação teórica, ética e política como 
base para o planejamento. execução. avaliação e direção de suas ações" (IAMAMOTO 1988b; p.57)

Nos últimos vinte anos, tal especificidade passa a ser respaldada pelo Código de Ética Profissional de 1986, revisado em 1993, que regulamenta a profissão de Assistente Social e o processo de formulação da Lei Orgânica da Assistência Social, que contempla a triade: qualidade de ensino, qualidade do trabalho e necessidade de especialização. Entretanto, este debate profissional acabou ficando a cargo de um pequeno grupo, elitizado e descolado da realidade social, portanto, do meio profissional e o grande contingente que ali estava não foi capaz de se apropriar dessa reflexão, impossibilitando sua tomada de consciência e inviabilizando a articulação entre prática e teoria (VASCONCELOS Op. Cit.).

De acordo com QUIROGA (1989), em estudo realizado com assistentes sociais docentes, foram evidenciados equívocos e contradições na própria condução de questões teórico-metodológicas na formação profissional. A análise da autora evidenciou o desconhecimento que têm acerca dos fundamentos da sociedade capitalista e a leitura inadequada que fazem da teoria marxista. Ou seja, no nivel do discurso expressam certa preocupação com a transformação social, na qual está inclusive a possibilidade da mudança do papel do Serviço Social, mas não sabem como encaminhar tal discussão em sala de aula. Assim, os alunos, futuros assistentes sociais, não apreendem criticamente o movimento da realidade social, tampouco o das práticas profissionais desenvolvidas historicamente, às quais irão dar continuidade (ou não). 
Em paralelo a esse pequeno resgate, Ana Maria, a assistente social entrevistada fez a graduação em meados dos anos 70, nas Facudades Metrpitanas Unidas, época em que surgiram em São Paulo inúmeros cursos superiores de Serviço Social. Tendo uma formação mais generalista, fez estágio voltado para área empresarial, pois sua ideia era trabalhar neste setor, já que era bancária e achava que poderia continuar atuando nesse contexto.

No inicio de 1978 prestou concurso na Prefeitura e foi chamada para assumir o cargo em janeiro de 1981. Por acaso, foi designada para a área da saúde, porque o concurso para assistente social, inicialmente, era para a Prefeitura como um todo, não era mencionada uma área especifica, mas naquele momento havia vaga na Saúde e, embora se identificasse com as áreas da saúde e habitação, sentiu grande impacto ao ir trabalhar no Hospital Municipal Tito Setúbal, em São Miguel Paulista, zona leste da capital:

(...) Então fui para lá, mas foi super interessante eu acabei adorando, porque o Tito Setúbal. na época, era a única referência para aquela população. Então era como uma provincia dentro de São Paulo, isso há vinte anos atrás, quando eu entrei. vinte e um anos atrás. Então eu via aquilo, ai que eu me dei conta da realidade social mesmo, caía tudo naquele pronto socorro, então eu ficava um tempo no pronto socorro, depois eu fui para a maternidade. "

Além do confronto com a dura realidade da população atendida, a tão mencionada realidade social, e com as necessidades de cuidados de saúde que 
demandavam, colocadas pela violência em que viviam, Ana Maria começou a se inteirar do Movimento de Saúde da Zona Leste que estava sendo gestado naquela época, cuja expressão e importância são reconhecidas até hoje:

“(...) Então era uma coisa interessante você ver uma outra realidade. eu me assustei muito, uma coisa é você estudar, saber que existe. de repente você vê pessoas que moram ali perto, mas que nunca botaram um pé num hospital público, porque trabalhavam em olaria e achavam que entrar num hospital não era coisa para eles. Era a mesma coisa que dizer: "o homem foi para lua", era algo tão distante que eles não sabiam, não entendiam o que era aquilo, quando alguém os levava para um atendimento. Então, nossa. dava para ver bem essa contradição da minha vida com o que eu encontrei ali."

Ana Maria trabalhou nesse hospital dois anos e conseguiu ser remanejada, pois era muito distante de sua casa. Em 83 foi transferida para o Hospital do Tatuapé e passou a trabalhar na ala de queimados. Nesse contato, começou a fazer grupo com os familiares, mais ou menos nos mesmos moldes que havia realizado anteriormente com puérperas: um trabalho voltado para a orientação de hábitos de higiene e orientação juridica.

Depois de um ano, passou a se interessar por habitação e conseguiu uma colocação, na época a Habitação correspondia a um setor, dentro da Secretaria Municipal da Familia e Bem-Estar Social - FABES -, e retomou o trabalho com os movimentos sociais, cada vez mais efervescentes, e desta vez era o Movimento de Favelas, Movimento Popular de Urbanização de Favelas da Vila Prudente, 
permanecendo nessa frente entre 1984 e 1993, pois se "identificava com os Movimentos". Em 1985, com a eleição de Jânio da Silva Quadros, foi criada a Secretaria Municipal da Habitação, mas os técnicos continuaram na área de Vila Prudente, atendendo às mesmas regiões, mesmo na gestão municipal seguinte, a partir de 1989, quando foram criados os escritórios regionais e a equipe que integrava foi para o Ipiranga.

Com a gestão Maluf, iniciou-se "um movimento de expulsão de assistente social" da Prefeitura e as frentes de trabalho do serviço social na Habitação foram, imediatamente, suprimidas e os assistentes sociais foram praticamente colocados à disposição e sua intervenção descaracterizada:

"(..) a gente já estava todo mundo no centro. São Paulo inteira. quem era da Habitação (...) Longe da população. Houve uns expurgos, quem tinha cargo foi expurgado e ali, internamente, você só ficava ali, não podia fazer absolutamente nada, não era para falar. não era para trabalhar (...) foi colocado para o assistente social mais um papel de informante. Então teve um movimento interno, (...) qualquer questionamento a gente sabia que ia redundar numa reprovação. num castigo, então a gente resolveu fazer um abaixo-assinado perguntando para a superintendente na época, por que nos era dado (...) somente esse papel se a gente podia contribuir com mais coisas (...) ai eles expurgaram com 77 pessoas, exatamente aquelas que tinham assinado. feito o abaixo-assinado. Então eu era uma delas, ai foi desse jeito: "então, se vira, agora você vai procurar uma vaga em qualquer Secretaria". 
$O$ incentivo que o serviço social teve na gestão Luiza Erundina pôde ser observado desde a mudança de nomenclatura da Secretaria, que passou a SEBES, Secretaria Municipal do Bem-Estar Social, à nomeação de nomes de peso do serviço sočial paulista, como Marta da Silva Campos, Rosalina da Cruz Leite, Aldaiza Sposati para as pastas da Habitação e Bem-Estar Social, e que, apesar de separadas, mantiveram suas linhas de atuação articuladas, direcionadas aos movimentos sociais e à participação popular, tendo no assistente social um de seus principais representantes junto ao poder público.

Como na Secretaria Municipal da Habitação só ficariam os arquitetos e engenheiros, Ana Maria e os demais assistentes sociais tiveram que pleitear outras colocações, sobretudo em função do abaixo-assinado que organizaram com o qual questionavam as "novas atribuições" do serviço social. A sensação de ter sido descartada foi amenizada frente à impossibilidade de trabalho e de outros mecanismos de transferência. Assim, com a "expulsão" teve que pleitear outro posto de trabalho. Como era concursada para a saúde e acreditando que talvez ainda valesse a pena investir nesta área, recorreu a ARS (administração regional de saúde) e foi designada para o NOAS (Núcleo de Obras e Assistência Social) que ficava dentro do Hospital João XXIII, na Moóca, próximo à sua casa. Segundo a entrevistada, o NOAS correspondia a uma central de dados estatísticos e diagnósticos populacionais da região que, aparentemente, não tinha uma função bem definida:

(...) eu descobri que ali no NOAS acabou sendo um reduto de pessoas que foram remanejadas de outros lugares à revelia. Fiquei, precisei sair de licença e quando eu voltei já começou dentro da Saude a onda do PAS." 
A região da Moóca foi a última a aderir ao PAS (Plano de Assistência à Saúde), no governo Celso Pitta, a partir de 1996, e um dos pólos de resistência da região era o HDI da Moóca. Foi quando Ana Maria tomou conhecimento de sua existência, pois havia uma movimentação grande da comunidade e dos profissionais para que o HDI não fosse fechado. Até então, nunca imaginara trabalhar em saúde mental e no pronto-socorro o contato com a psiquiatria tinha sido muito fluido.

Nesta "falta de rumo", Ana Maria tirou nova licença sem vencimentos, de 96 a 98, e neste ano se aposentou no banco em que também trabalhava e queria retomar as atividades do serviço social. A única opção que apareceu foi no Centro de Farmacodependência, em unidade localizada na região central da cidade:

“(..) Então foi ai o meu contato com a Saúde Mental. Adorei. eu não imaginava que eu fosse me dar bem, acho que eu fugia muito da psiquiatria, (..) Mas como eu não tinha destino, eu queria algo novo mesmo. eu falei: "então, eu vou encarar isso daqui". Eu adorei. eu simplesmente adorei trabalhar com dependência de álcool e drogas. Fui com muito medo, porque eu não sabia absolutamente nada. não entendo até hoje. entendo muito pouco das doenças... (...) Mas foi nessa equipe (...) que eu pude ver um outro lado, mesmo da minha profissão, que eu poderia estar fazendo algo novo. "

A vaga solicitada pela unidade de farmaco-dependência era para assistente social especificamente, para a realização de um trabalho com os familiares. Esses serviços estavam bastante organizados, com um grupo de estudos em terapia familiar, 
com o qual Ana passou a estudar, e foi ai que colocou-se a possibilidade - e o desafio - de um atendimento familiar por assistente social, tendo a retaguarda da equipe, que reconhecia a necessidade do assistente social nesta tarefa, e da supervisão que esse grupo teve durante o tempo em que Ana permaneceu lá:

“(...) 'Bom. deve dar um choque ai por conta da profissão. de formação, eu não tenho formação nenhuma: E a coisa que eu menos queria era ficar dando passe, passar telefone. fazer encaminhamento, só aquele meramente formal, e com o atendimento familiar mudou totalmente. Ai como eu me identifiquei, eu me achei, tinha um grupo que dava suporte, no estudo, ai eu me voltei mais para essa área. E estava indo, nós conseguimos supervisão inclusive, não de familia. mas na unidade as equipes pleiteavam supervisão mesmo para o serviço."

Nova mudança de gestão, novas prioridades, mais mudanças e caminhos que se cruzam. Como Ana havia conhecido o Jorge e a Márcia Innocêncio, psicólogo e terapeuta ocupacional do HDI, ambos exilados no serviço de farmaco-dependência por conta do PAS, eles a convenceram a ir para o HDI, dado que uma das assistentes sociais havia se aposentado nesse intervalo. E em junho de 2001, quando a equipe do HDI retorna ao trabalho, Ana acaba indo também:

“(..) Eu sabia que era uma equipe mais unida ideologicamente. briguenta, eu falei: 'como é que eu vou me dar nesse meio?', dava muito medo. E também, por trabalhar com criança, criança nesse estágio de vida, eu falei: 'imagino que deva ser um negócio muito dificil'. E foi mesmo. mexeu muito 
comigo. Acho que me dei bem. ou melhor, acho que estou bem. Mas eu voltei a fazer psicoterapia. porque eu acho que ai também veio o fato de eu ser mãe. mistura muita coisa. Eu tenho uma criança e eu nunca tinha visto um autista. eu fui ver aqui. É muito legal, é muito interessante quando se cria um vinculo e mesmo com a familia. mas é muito dificil, eu acho que agora eu já estou numa outra fase. eu já estou um pouco mais racional. eu consegui separar um pouco mais...

Neste caso, é possivel observar que a formação em serviço social e a breve, porém fértil, experiência com terapia familiar no ambulatório de fármaco-dependência conferiu à Ana certa autoridade técnica para o trabalho com familias, identificada por seus colegas, que reconheceram certas peculiaridades da terapia familiar realizada por assistente social.

Assim, parece que a trajetória de Ana, desde o momento de sua formação, é bastante ilustrativa da dificuldade de uma articulação teórico-prática dos assistentes sociais, como discutido inicialmente, ao mesmo tempo em que ela, ao ser defrontada com as realidades e novas demandas, foi em busca de "um lugar ao sol" e, ao que tudo indica, ainda está buscando. 


\subsubsection{Do Alienismo ao Organicismo: quem tem medo da 'Nova Psiquiatria'?}

No século XVIII, na Europa, a loucura passou a adquirir um status social de enfermidade, à qual se vinculou novas tecnologias de intervenção. Em um contexto sócio-econômico em transformação, encorajado pelos progressos na investigação biológica, a psiquiatria como saber racional, fortemente imbuida do empirismo experimental próprio da passagem do século XVII para o XVIII, é levada a forjar novas práticas de contenção e controle do louco e da loucura, dado que as práticas sociais como um todo perseguiam novas alternativas, deflagrando os novos paradigmas de conhecimento (FOUCAULT 1992).

O pressuposto fundamental da psiquiatria era o do isolamento terapêtico, uma forma atualizada da segregação asilar do século XVII, decorrendo dai nova configuração do tratamento moral - para além do corpo - dispensado ao alienado mental. O suporte institucional para as novas práticas era o hospicio e seu principal agente o alienista (FOUCAULT 1989). Como indica VENÂNCIO (1993; p. 122):

"Ser alienado mental significava ser um individuo de 'paixões' excessivas. afetos intensos, que se sobrepunham à 'vontade'. Esta última, por sua vez. era caracterizada como a instância em que se produzia o que era e o que não era permissivel ao individuo, tendo em vista a atenção com sua dimensão social". 
Essa noção de vontade ${ }^{1}$, que considerava os aspectos interpessoais e intrapessoais do sujeito, gerou novas possibilidades de explicação acerca da "etiologia" da loucura, identificando no fracasso dos vinculos e das relações sociais, especialmente as familiares, sua causa. Nesse sentido, se justificava o isolamento não como forma de exclusão social, mas como medida de contenção dessas paixões, impulsionadas pela vida em sociedade, e como possibilidade de uma incursão a individualidade (BIRMAN 1978).

Isso não significa que a psiquiatria, a despeito de neste momento desviar seu foco de observação da medicina anátomo-patológica, ainda não procurasse os fundamentos orgânicos das "perturbações fisico-morais". Na verdade, essa tensão entre a moral e o corpo, a natureza e a cultura o individual e o social corresponde ao debate intelectual e científico que marca a transição do século XVIII para o século $\mathrm{XIX}$, na qual se inserem as disciplinas e teorias das ciências humanas e sociais, como a sociologia a psicologia, a economia, a antropologia

Na cidade de São Paulo, por sua vez, os primeiros indícios dessas práticas datam de metade do século XIX, quando são designados alguns dormitórios para a internação de alienados no hospital da Santa Casa, pois esta se recusava a assumir integralmente a responsabilidade por este tipo de assistência.

Em função dessas recusas, o então Governo da Provincia foi obrigado a tomar providência e em 1852 é fundado o primeiro Hospício de São Paulo, inaugurado com

\footnotetext{
1 A noção de vontade também foi bastante trabalhada pela sociologia, principalmente, a chamada "Sociologia da Passagem do Século", cujos maiores representantes foram os alemães George Simmel, Max Weber e Ferdinand Tönnies. As teorias dos dois últimos tentaram recuperar os aspectos individuais da ação social em oposição ao determinismo biológico francês e ao determinismo histórico marxista.
} 
apenas 6 internos, entre os quais criminosos, egtessos da Casa de Correição ${ }^{2}$, o que sinalizava o inicio das relações entre os âmbitos da justiça e loucura. A força de trabalho destinada à vigilância e disciplina dos alienados era composta pela "escória" dos trabalhadores livres da época, entre os quais negros libertos e seus instrumentos de castigo e contenção eram cordas, camisas de força, correntes. A situação de insalubridade das instalações e as condições sanitárias precárias foram agravadas pelo rápido crescimento desse contingente populacional e contribuíram para que o local se tornasse foco epidêmico de várias doenças, o que resultou na transferência dos internos para outras instalações, mantendo-se a mesma proposta disciplinarizante. A superlotação criava um sistema de internações breves, permanecendo apenas os mais “agitados". Do total de internações realizadas até fins do século XIX, metade resultou em morte (PALMA Op. Cit.).

No final do século XIX, com a criação do Serviço Sanitário, seriam instituidos os asilos agrícolas, destinados aos pacientes mais "comportados", com os quais era experimentada a laborterapia, a "cura pelo trabalho", enquanto que os demais internos ficariam reclusos no Manicômio São Paulo até sua extinção, agora sob os cuidados de médicos clínicos e do diretor clínico, o Dr. Francisco Franco da Rocha, considerado o primeiro alienista brasileiro ${ }^{4}$. Em 1898 era inaugurado o Hospício do Juquery, marcando uma nova fase da psiquiatria brasileira, caracterizada por um novo conjunto de terapias, que passaria a abrigar os remanescentes do Manicômio (CUNHA 1986).

\footnotetext{
${ }^{2}$ Grafia da época, mantida pelos autores consultados.

${ }^{3}$ A noção de alienação pelo trabalho já tinha sido objeto de discussão de Karl Marx, em sua Crítica da Economia Politica.
} 
Tantas tecnologias não lograram mudanças na condução bárbara e ineficaz do tratamento dos alienados, que permaneciam sob forte vigilância. $\mathrm{Na}$ nova estrutura, cuja arquitetura era opressora e favorecia os mecanismos de controle e castigo, a despeito das colônias agrícolas a ela vinculadas sugerirem uma atmosfera pretensamente bucólica, mantinha-se para os internados uma terapêutica moral baseada na violência fisica e na balneoterapia, na qual o doente deveria ficar deitado de 15 a 20 dias e, para os semi-internos, a exaustão pelas longas jomadas de trabalho.

Até 1935, no Estado de São Paulo, seriam criadas clinicas especializadas, instalado-se aí o Manicômio Judiciário e o pavilhão-escola dos "menores anormais", orientados pelas propostas da Higiene Mental; foram estruturados os primeiros serviços ambulatoriais da Capital e criados 15 hospitais para moléstias nervosas e mentais também no Interior, sendo que a maior parte dos leitos gratuitos ainda estava no Juqueri, que passou, já a partir dos anos 20 , a ser considerado a sede brasileira da pesquisa cientifica nesta área, contando com a colaboração de estudiosos do sistema nervoso central, vindos da Europa, que impulsionaram os “avanços" dessas práticas e enunciaram as possibilidades de cura, como dito anteriormente, em substituição à ineficaz psiquiatria alienista que revelara o aspecto da cronicidade e perpetuação da loucura. A substituição da denominação hospicio por hospital teve a finalidade de desestigmatizar os internados e os egressos.

Portanto, ao longo da primeira metade do século $\mathrm{XX}$, a assistência psiquiátrica em São Paulo, e no mundo, ainda seguiu os rumos do organicismo ${ }^{5}$ e,

\footnotetext{
4 A respeito desse periodo e do discurso científico da época sobre a doença mental. ver VASCONCELLOS, 1992.

'Refere-se ao paradigma dominante do século XVIII, marcado por intensos progressos científicos, principalmente no campo das ciências biológicas, que fortaleceram a concepção de que o mundo é
} 
muito embora a psicanálise nesta fase tenha aprofundado suas reflexões sobre os problemas psicopatológicos, "não fora utilizada como recurso terapêutico em instituições públicas" (VENÂNCIO Op. Cit.).

Após a Segunda Guerra, no cenário mundial, a necessidade de reconstrução social e de recomposição da solidariedade e cidadania, esmagados pelo totalitarismo nazi-facista. incentiva a concepção de um "Estado Bem-Estar Social" e o planejamento de políticas sociais ${ }^{6}$. No campo da psiquiatria, tanto na Europa como nos Estados Unidos, surgem novas proposições de cunho 'experimental', em principio radicais e alternativas:

"as comunidades terapêuticas e a Antipsiquiatria. na Inglaterra: a Psicoterapia Institucional e a Psiquiatria de Setor, na França: a Psiquiatria Comunitária ou Preventiva. nos Estados Unidos; e, no final da década de 1960. a Psiquiatria Democrática. na Itália. Experiências que se opunham à prevalência da atenção à fisicalidade da doença mental e. principalmente. ao isolamento terapêtico. reivindicando a necessidade da 'desinstitucionalização':" (IDEM 127).

Esta 'nova psiquiatria', que busca recuperar a dimensão moral e social da doença mental sob a égide da igualdade, por intermédio da linguagem dos direitos (LEFORT 1987), se propõe a negociar socialmente os antigos espaços da diferença

fundamentalmente homogèneo e que todos os fenômenos devem se explicados e entendidos a partir da funcionalidade ou disfuncionalidade que apresentam.

${ }^{6}$ Sobre a temática da proteção social e sistemas de solidariedade nacional, nucleados pelo trabalho e pelos direitos dele decorrentes, representados pelo chamado Estado de Bem-Estar Social pode ser encontrada em ANTUNES L. Crise e perspectivas da sociedade salarial: algumas observações sobre 
em que a doença mental e as intervenções sobre ela se expressaram. Nesse sentido, a nova psiquiatria ou a antipsiquiatria ${ }^{7}$, como ficou conhecido esse movimento de ruptura nos paises capitalistas centrais, procurou rever as formas de assistência dirigidas a essa clientela que concretizassem, senão a cura, pelo menos a reinserção social do doente mental.

Nesse panorama, aparecem os chamados serviços substitutivos no Brasil, inspirados pelas alternativas estrangeiras, nas modalidades ambulatorial, hospital dia, centros de atenção psicossocial e centros de saúde comunitária, cujo objetivo era oferecer tratamento intensivo sem o afastamento familiar, persistindo ainda a ordem asilar (PITTA-HOISEL Op. Cit.). Ou seja, esses novos modelos institucionais, embora propusessem a desospitalização, não superaram a institucionalização almejada pela Psiquiatria Democrática italiana, cuja proposta radical era a de autogestão dos individuos sobre si mesmos (BAZAGLIA 1985), mas ao encerrarem características do modelo inglês de comunidade terapêutica ${ }^{8}$, e até mesmo do modelo francês, avançaram qualitativamente em relação os métodos violentos e autoritários do modelo organicista

as novas formas da sociabilidade, da solidariedade e da cidadania. In: Revista de Ciências Humanas e Sociais da UNISA 2000; $2(1)$ : 5-14.

7 Em meados dos anos 70, na França, um grupo de psiquiatras das gerações de 20, 30 e 40, intitulados como "anti-antipsiquiatras", organiza um fórum de discussão em que re-batem as proposições da antipsiquiatria, entendida por alguns destes como "brutal questionamento" das práticas psiquiatricas ou como um dos "elementos complementares de um par, de que a Antipsiquiatria è a má consciência necessária para que o conhecimento também não se torne mau". In: KOUPERNIK C, (organizador.). Antipsiquiatria: senso ou contra-senso? Rio de Janeiro: Zahar Editores; 1976.

${ }^{8}$ Esta modalidade de tratamento tem sido utilizada, com sucesso, em dependentes químicos, devido ao baixo custo e a possibilidade de "alavancar" mudanças no estilo da vida dos "residentes". Ver: MASSONI AL; AROUCA AL. Relato de uma experiēncia: conhecendo "por dentro" uma comunidade terapêutica. Interações 1999; 4(7): 131-135. 
$\mathrm{Na}$ verdade, é na permanente articulação entre o social e o individual que a nova psiquiatria reivindica a inserção do individuo na sociedade, pelo reconhecimento da subjetividade do sofrimento no coletivo. Esta alteridade, por sua vez, possibilita resgatar aqueles aspectos intrapessoais em outras bases, pela "positividade do valorIndividuo" e permite considerar a capacidade de ser saudável, ou seja, ter sua saúde mental e esta também estar representada nessa subjetividade.

Maria do Carmo, a psiquiatra entrevistada, fez sua graduação e residência em psiquiatria geral entre os anos de 1979 e 1987, na USP de Ribeirão Preto. Já em 1987, ao chegar a São Paulo, iniciou formação em psicoterapia psicodinâmica no Instituto Sedes Sapientae, instituição superior de formação em psicanálise, fundada em 1933.

Em termos profissionais, deu alguns plantões na especialidade fora do Hospital das Clínicas, onde fazia residência. Em 1986, prestou concurso para a Secretaria de Estado da Saúde e assumiu, em 1987, a vaga de médico psiquiatra no Ambulatório de Saúde Mental do Belenzinho, justamente no momento em que ocorria grande mobilização, deflagrada pelas discussões em torno da Reforma Sanitária e da Reforma Psiquiátrica Brasileira, que seriam encaminhadas em termos de propostas de políticas de saúde na $8^{2}$. Conferência Nacional de Saúde em 1986 e na $1^{2}$. Conferência Nacional de Saúde Mental, em 1987.

Os Ambulatórios de Saúde Mental, no início dos anos 80, ainda desenvolviam suas atividades pautadas no modelo médico individual: consultas médicas e intervenção medicamentosa e, em que pese a presença de profissionais de diversas 
categorias, ainda não havia um trabalho multiprofissional na maioria das unidades (PITTA-HOISEL Op. Cit.):

“(...) foi um salto qualitativo a gestão do Montoro no Estado. que foi o outro o anterior a esse... (...) em se pensar os ambulatórios de saúde mental do Estado. com equipe minima de saúde mental nos centros de saúde. E nesse outro salto qualitativo, a cidade de São Paulo faz um "bum", porque faz uma série de eventos pondo nas ruas a questão do eletrochoque, a questão dos abusos de violência dentro dos manicômios. pondo nas ruas o luta antimanicomial com sociodramas, com exposições e dando uma alternativa real à internação com a psiquiatria na rede básica e com os $H D$ de retaguarda.(..) É diferenciada. porque os ambulatórios, na época em que eles surgiram, certamente deram uma resposta muito avançada ao que se tinha, porque o número de internações psiquiàtricas num primeiro surto, numa situação controlóvel. numa psiquiatria ainda de unidade básica. naquela época existia um número muito grande de internações psiquiátricas e a pessoa entra na primeira internação e fica 3 meses logo de cara. inclusive por interesses espurios do hospitais psiquiátricos mesmo, que lucram com nessas internações. A Ana Pitta foi uma pessoa muito responsável diretamente nessa gestão do Montoro. Eu. naquela época. estava em São Roque, eu participei do que foi a extensão desses serviços nas cidades do interior do Estado. onde sequer havia um psiquiatra. quando ocorreu o treinamento dos médicos clinicos para generalistas. que passaram $a$ atender os casos psiquiátricos e o que na verdade existia antes é que o 
prefeito comprava a ambulância, enchia a ambulância de gente e mandava para o manicômio mais próximo. esse era o tratamento... até os anos $80 . .$. (PSIMR)

Esse vinculo ainda estava mantido à época da entrevista, em que completaria 16 anos de trabalho no Ambulatório e de onde estava afastada, e Maria do Carmo mencionou a intenção de dispor definitivamente dele.

No final de 1987 também prestou concurso para a Prefeitura e foi designada para um posto de saúde, permanecendo entre 87 e 90, onde conheceu Márcia Ramos, a diretora do HDI, então colega de trabalho e de 'Sedes'. Entre 1990 e 1992, foi removida para outro posto de saúde até sua vinda para o HDI. Embora não tenha me detido nas atividades que realizava nesses postos de trabalho, foi possivel apreender sua percepção acerca da qualidade da assistência de saúde mental prestada pela atenção básica Segundo Maria do Carmo, é impossivel um atendimento mínimo, de qualidade, sem uma equipe mínima de profissionais, pelo menos um médico psiquiatra e outro clínico, que assumam esses atendimentos e possam se responsabilizar pela continuidade deles. Além disso, de acordo com ela, ainda persiste 0 embate entre $\circ$ discurso politico e técnico acerca da necessidade do controle de medicamentos.

Segundo o primeiro, inspirado ingenuamente e possivelmente pelas propostas da Reforma Psiquiátrica, é a instituição que cronifica o paciente e em nome disso assume uma politica antimedicamentosa. $\mathrm{O}$ segundo discurso rebate, enfatizando a necessidade que o paciente tem de tomar a medicação para se sentir bem: 
“(..) Tem uma psiquiatra aqui. trabalhando no posto. ela é sozinha. Eu acho um desperdicio de recurso. Outro dia mesmo a chefe do posto estava reclamando que a psiquiatra entrou de licença $e$ não tem quem dê a medicação para os pacientes que estão estáveis. Isso é uma temeridade. você corre o risco do profissional se demitir e tal e você fica com uma leva de pacientes que são crônicos, que precisam de medicação e que vão ficar sem e tal... (...) porque eu acho também que tem uma politica muito burra de controle de medicação, necessita do médico para manter a medicação, porque às vezes o paciente está tomando o remédio há quatro anos, precisa do remédio. é o que está mantendo ele bem. (...) mas esse aspecto é negado. Olha como é a perversidade da coisa. Se o paciente toma remédio há quatro anos é porque ele foi cronificado, esse é o discurso politico. $O$ discurso técnico é que ele é crônico e precisa disso para se manter bem (...) Então, eu acho que tem que ter uma equipe também nesses serviços, no minimo com dois psiquiatras (...) ou então vai ter que ter um clinico que assuma (...) de manter a medicação, isso é um entrosamento entre a equipe que não existe. Eu vou te falar, eu não volto a ser psiquiatra de posto nunca mais na vida, porta de entrada não." (PSIQMC)

Quando chegou ao $\mathrm{HDI}$, sem nenhuma experiência em psiquiatria infantil, Maria do Carmo acreditou na possibilidade de haver naquele espaço, simultaneamente, um hospital dia adulto, pois tinha interesse por essa população, devido ao seu trabalho no Ambulatório de Saúde Mental do Belenzinho, mas aí foi 
aprendendo com a prática e ampliando seu conhecimento e suas perspectivas, inclusive:

“(...) quando eu vim para cá eu tinha a ilusão, porque eu não tinha experiência com psiquiatria infantil (...) de que também ia ter um HD de adulto (...) mas ai foi se configurando, a gente começa estudar e fui aprendendo com a prática (...) na medida em que eu pude estar ampliando meu conhecimento, tendo mais experiência, consegui ter uma visão não apenas psicodinâmica. acho que hoje tenho uma visão bem mais clínica das patologias. acho que hoje em dia sou mais escutada nessa visão, pela equipe, então eu acho que isso foi um processo assim..."

Vale destacar, ainda, que no final da gestão Maluf, na eminência da implantação do PAS, Maria do Carmo assumiu a diretoria do HDI ao voltar de licença maternidade, pois nesta época a direção da unidade ainda era exclusividade da categoria médica. Em substituição ao médico designado pelo diretor da ARS da Moóca, Maria do Carmo assume em caráter de emergência, com continência e retaguarda da equipe, que ainda permanecia, e até conseguiram algumas coisas interessantes, como a articulação da parceria com a psiquiatria infantil do HC na tentativa de trazer a residência para o HDI. Mas na transição de gestão, e depois com a implantação do PAS, todos foram forçados a sair:

“(...) ai juntou com toda a confusão do PAS, então foi uma época super complicada de estar gerenciando. Eu estava enlouquecida, todo mundo enlouquecido. Acho que teve uma época em que o grupo ficou totalmente não 
funcionante, no sentido de (..) por exemplo, eu não conseguia mais. minimamente, fazer uma triagem. dar qualquer encaminhamento. A gente ficou paralisado um bom tempo, tentando se manter aqui dentro. então a gente trabalhou muito. teve uma reforma nesse meio. que a gente conseguiu pintar as portas coloridas. Por outro lado, era uma coisa fantástica. porque assim. 'olha, a comissão cientifica vai cuidar de estágio'. eu só assinava. Era uma equipe muito legal. As pessoas se propunham a fazer as coisas e faziam mesmo. Então, era muito legal de você estar coordenando. Acho que essa equipe tem essa caracteristica de as pessoas serem assim, além de terem uma boa formação. são muito responsáveis. Não que todo mundo trabalhasse assim, mas a maioria e isso é uma raridade em serviço público. Já trabalhei em outros lugares e isso não existe. Então, é uma coisa que eu sempre falava: 'a equipe é fácil, a situação é que è complicada:."

Neste momento, Maria do Carmo foi transferida para o Centro de Referência Infantil, onde ficou por dois anos e nos anos seguintes foi para o Centro de Referência do Trabalhador, equipamentos que atualmente integram a rede de serviços de saúde mental, no Distrito de Saúde da Moóca, como já mencionado. 


\subsection{3 'O que quer, o que pode essa lingua?': a emergência das práticas fonoaudiológicas em São Paulo}

O modelo alienista da psiquiatria se faz presente também entre as práticas fonoaudiológicas, em São Paulo. Em 1933, o Código de Educação do Estado previa o isolamento em classes especiais de crianças que apresentassem problemas de linguagem, para as quais era destinada 'correção', cuja aproximação médica possibilitava o "diagnóstico das disfonias, dislalias, gagueiras, tartamudeio, assim como afeç̧ões bucais, nasais ou mentais". Decorriam dai ações de cunho educativo, a cargo de profissionais especializados, habilitados para a condução da higienização da voz ou mesmo da reeducação de linguagem anormal, desde que orientados por médicos (FIGUEREDO NETO 1988).

De acordo com BERBERIAN (1993), sob o forte espirito nacionalista herdado da Semana de 22, em que as idéias modernistas acerca de "um projeto sóciocultural para o Brasil" começaram a ser discutidas por intelectuais, é que em julho de 1937, às vésperas da intervenção do Estado Novo, era realizado no Teatro Municipal de São Paulo o I Congresso da Lingua Nacional Cantada. Organizado e concebido pelo então diretor do Departamento da Cultura do Município, o escritor Mário de Andrade, foram reunidos, além de intelectuais, educadores, médicos, higienistas e lingüistas para debaterem suas reflexões acerca da variação lingüistica encontrada nos cantos e dialetos regionais e os vícios e defeitos da fala de crianças e daqueles trazidos pelos imigrantes, cujo intuito era 0 de buscar uma uniformização da língua portuguesa e, assim, fortalecer o sentimento da nacionalidade brasileira. 
Nasciam, assim, as primeiras tecnologias de intervenção, pautadas também por esse ideário nacionalista e educativo, com a criação das escolas ortofônicas, cuja regulamentação se deu nos moldes segregacionistas daquela direcionada aos deficientes físicos e mentais (FIGUEIREDO NETO Op. Cit.) e que estão na origem das Clínicas de Saúde do Escolar, existentes até o final dos anos 80, em São Paulo, referidas pelas entrevistas realizadas.

O Laboratório de Fonética e Acústica do Departamento de Cultura seria criado em 1947, para a realização de pesquisas com crianças que apresentassem esse problemas de linguagem Contando com uma diversidade profissional que comportava otorrinolaringolistas, educadores sanitários, psicólogos e engenheiros, o laboratório fazia experiências acústicas, as quais eram repassadas para ações educativas, conduzidas por foneticistas e ortofonistas em instituições, como a AACD Associação de Auxilio à Criança Deficiente. Em meados dos anos 50, era criado o primeiro curso técnico para a formação de auxiliares especializados no Hospital das Clínicas da USP (IDEM).

Entre 1957 e 1965, a aquisição de linguagem passa a constituir um campo sistemático de pesquisa nos Estados Unidos, e as propostas de Noam Chomsky, cujas formulações daquilo que chamou de problema lógico da aquisição de linguagem. integravam-se às teorias lingüisticas:

"Sendo a sintaxe o componente gerativo das linguas, na medida em que são suas propriedades recursivas que permitem definir qualquer língua como possivel de produzir um número infinito de enunciados, a fala a que a criança é exposta e a partir da qual supõe-se que aprenda a lingua de uma 
comunidade torna-se por definição insuficiente. A referência a um infinito de enunciados possiveis é, para Chomsky, uma implicação de sua concepção da sintaxe gerativa, isto é, das propriedades recursivas que respondem pela especificidade das estruturas sintáticas, propriedades essas que não são observáveis.. (...) um dos argumentos cruciais de Chomsky assenta na hipótese de que estruturas superficialmente semelhantes são produtos de processos estruturalmente diversos, processos esses, portanto. não passiveis de percepção. (...) o problema lógico da aquisição de linguagem é a atribuição ao individuo da espécie humana de um dispositivo inato para adquirir linguagem, em um tempo relativamente curto e fora de uma situação de ensino-aprendizagem." (LEMOS 2000; p.55).

As idéias de Chomsky desencadearam grande número de pesquisas em universidades americanas e em outros paises, e em São Paulo, nascia um curso superior no Instituto de Psicologia da PUC, mais voltado para o campo da lingüística, em 1962. Desta forma, as maneiras de pensar a aquisição da linguagem e os desvios e problemas que aparecem nesse processo, começaram a se deslocar do enfoque puramente médico, patologizante para a perspectiva da psicologia do desenvolvimento, que tomava a fala da criança como evidência empírica de uma série ordenada de estágios do conhecimento lingüístico (LEMOS Op. Cit.).

Essa versão psicologizante e empirista perdurou até finais dos anos 60 , quando psicólogos e lingüistas, sob a denominação de psicolingüstas, empunhariam 
gravadores registrando as falas de crianças pequenas ${ }^{9}$, com o objetivo fundamental de buscarem as "evidências" daqueles dispositivos inatos que permitiam às crianças reconhecerem e desenvolverem a linguagem. Tal empreendimento, portanto, buscava a legitimação da lingüística como ciência ${ }^{10}$ e o seu fracasso pôde ser explicado e reconhecido por esses teóricos, pois:

"Sistema e/ou estrurura são incompativeis com a concepção de lingua como um objeto de conhecimento parcelável, cujas unidades, categorias, regras ou estruturas possam ser odenadas segundo graus de complexidade definidos relativamente a uma suposta natureza do aprendiz." (IDEM; p.56).

\footnotetext{
- Esta metodologia também pode ser observada, no mesmo periodo, nas pesquisas sociológicas filiadas à Escola de Chicago, nos Estados Unidos.

${ }^{10}$ A Antropologia estrutural também recorre à linguística para a sua elaboração teórica, mas o faz a partir de outro caminho, já dialogando com a psicanálise, entendendo a linguagem como meio de simbolizações. A este respeito, ver: Claude Lévis-Strauss. Antropologia Estrutural. Vols 1 e 2.
} 
A partir daí, passa-se a duas abordagens que consideram a implicação da dinâmica das relações sociais na aquisição da linguagem e nas formas de sua representação: uma, de caráter psicanalítico, em que a aquisição da fala corresponde ao processo de subjetivação, ou seja, a fala consiste em um dos referenciais no qual a construção da identidade se apóia e por intermédio da qual é feita a negociação social de sua construção; a outra, pedagógica, que privilegia o entendimento dos mecanismos do ensino-aprendizagem como facilitadores ou comprometedores desse processo de aquisição e percepção da linguagem (MAIMONE 2000).

A regulamentação profissional da fonoaudiologia, por sua vez, só aconteceria na década de 80 , momento em que esses profissionais seriam absorvidos pela rede pública escolar e de saúde.

As duas fonoaudiólogas entrevistadas, Liege e Marici, fizeram sua formação acadêmica entre 1979 e 1987. Liege estudou na Escola Paulista de Medicina, onde, em 1983, fez especialização em audiologia clínica e em otoneurologia, para a realização dos exames audiológicos e diagnóstico, cuja abordagem era estritamente médica. Começou a trabalhar em consultório com audiologia e se deparou com "muito caso de voz"; foi quando percebeu que a fonoaudiologia tradicional não dava conta dessas questões e resolveu recorrer à psicologia:

“(...) falei 'deixa eu fazer o mestrado', em vez de fazer faculdade de novo. ai eu fiz o mestrado na USP em Psicologia Social. Eu entrei lá em 85. 86, (...) eu sempre fiz terapia, (...) mas o que me levou mais em busca da saude mental foi o trabalho com voz, porque só o exercício não adiantava. eu via que tinha alguma coisa a mais e ai eu comecei a trabalhar com as crianças 
de um jeito diferente, tanto que eu tinha um retorno das mães falarem 'nossa. ela melhorou muito em outros aspectos. a terapeuta que fazia as vezes como psico falou tal e tal coisa...', foi dai que fui buscar mais a área de psico, saude mental (...)" (FONOL)

No inicio dos anos 90, Liege iniciou seu trabalho na Secretaria Municipal de Saúde via concurso público e foi trabalhar em um posto de saúde, onde estabeleceu parceria com a psicóloga, pois ambas acreditavam que um trabalho com criança deveria, necessariamente, envolver a familia. Como a demanda era grande, tanto para a fonoaudiologia e psicologia, encaminhada pela rede de ensino, cujos problemas de leitura e escrita vinham acompanhados por problemas de comportamento, Liege e a psicóloga resolveram juntar os dois atendimentos em um, fazendo a triagem dos casos, que consistia em uma série de reuniões em grupo com as mães, em que contratos eram feitos no sentido de explicarem as regras e objetivos do atendimento.

Cerca de oito meses depois, também em função de seu mestrado, é convidada a participar da equipe que estava implantando os $\mathrm{HD}$ na rede:

“(..) O primeiro momento foi de muita briga. porque a gente estava brigando com o pessoal da saúde escolar. queriam manter aqui como saúde escolar. então foi um período assim bem dificil. a gente precisava brigar para que houvesse o hospital dia. Eu era muito mais engajada politicamente (...). No governo da Erundina, a gente comprava uma briga e comprava mais as idéias ou a gente era mais jovem (...) Ai a gente foi aprendendo. Foi, assim. começou a aparecer psicótico, eu já tinha atendido um. dois, três na 
vida. mas ai pelo o que eu tinha estudado, a gente foi estudando. foi trocando em reunião. brigava muito, um xingava o outro, e assim: 'você não é psico. você é só fono. fono não faz isso, fono não faz aquilo. Você está na minha área: Tinha umas coisas muito assim. E tinha um pessoal muito psicanalista. um pessoal junguiano. tinha muita distinção entre nós também e com as supervisões, com o ensaio e erro, a gente foi crescendo. A gente pegou supervisão de fora. a gente fazia supervisão fora, ai a gente foi aprendendo a se respeitar, a se escutar. a se conhecer." (FONOL)

No final de 1992, Liege foi para o exterior onde fez estagio em uma escola para "crianças dificeis", e seu mestrado sobre estigma contribuiu muito para a sua ida e seu trabalho, que consistia em reforço escolar para crianças e para pré-adolescentes com distúrbios de aprendizagem Além isso, eram individuos marginalizados pelo subemprego, pela miséria e pelo puritanismo irlandês. Assim, aproveitando a oportunidade, realizou, tambem, atividades de promoção em saúde e prevenção, sobretudo com orientações a respeito de contraceptivos, dos riscos da gravidez na adolescência e de doenças sexualmente transmissiveis:

“(...) Quando eu voltei da Irlanda. estava o Maluf. Ah! Foi triste, foi muito triste. Eu já estava triste. porque tinha voltado e voltar com o Maluf foi muito ruim.(..) Voltei para cà. fiquei até... e ai o que aconteceu? Quando estava para entrar o PAS, eu fui para a Finlândia, aliás na Finlândia eu trabalhei com obssessivo-compulsivo como acompanhante terapêutica. foi outra coisa bem legal que acabou acontecendo e ai eu voltei e não tinha mais HD. Isso foi 
muito ruim. A equipe toda se sentiu exilada, se sentiu órfã. todo mundo conta a mesma experiência de buscar uma equipe e não encontrar a equipe." (FONOL)

Durante a implantação do PAS na rede de saúde foi "convidada" a se retirar e acabou indo para o Centro de Referência em AIDS, em que fazia a parte de recepção e devolução de exames e acompanhamento para discutir a adesão dos HIV positivos ao tratamento:

“(..) dai eu comecei a fazer de novo esse trabalho: "não é só medicamento, por que é que eles não tomam medicamento? Vamos ver por que eles não estão tomando. qual é o significado da AIDS para eles?". Isso ia virar tese de doutorado, mas dai, voltei para cá..." (FONOL)

Marici se formou na PUCSP em 1987 e desde finais da graduação já era estagiária da Clínica de Saúde do Escolar, na gestão Jânio Quadros. Fez vários cursos extracurriculares em distúrbios da linguagem e saúde mental, também na PUC. Como parte da Educação, a antiga clinica desenvolvia um trabalho voltado para crianças da rede de ensino municipal com distúrbios articulatório, de leitura e escrita, de aprendizagem e, como também compreendiam as Escolas Municipais de Educação Infantil - EMEI's -, apareciam casos de deficiência auditiva, autismo, algumas psicoses, que vinham encaminhados com diagnóstico de problema de linguagem, mas depois do diagnóstico fonoaudiológico acabavam sendo assumidos pela equipe da 
clínica, que contava com psicólogos, psiquiatras e assistentes sociais, entre os quais, a Glória, que passou a integrar a equipe do HDI.

Como na época não havia concurso público para fonoaudiólogos, as contratações aconteciam por "indicação política", Marici foi admitida em 1988 ainda na Clinica de Saúde do Escolar da Moóca.

Entre 89 e 90, foi realizado o primeiro concurso para fonoaudiólogos na Prefeitura, Marici foi aprovada e optou pela vaga no HDI. Mas com a extinção das clínicas de saúde do escolar, parte das crianças atendidas foram encaminhadas para a UBS e Marici foi designada para substituir a fonoaudióloga da Unidade Básica de Saúde da Moóca que estaria assumindo o cargo de chefia da unidade. Assim, alguns dos casos da clínica foram herdados pelo HDI, enquanto que os demais pacientes, cuja maioria apresentava distúrbios articulatórios, passaram a ser acompanhados por Marici na UBS da Moóca, onde ficou, praticamente, durante toda a gestão da Erundina, respondendo pelo ambulatório e também fazendo um trabalho em parceria com alguns profissionais do HDI, pois atendiam casos em comum:

“(..) eu fiquei no lugar dela. fazendo o trabalho de atenção primária, eu também fazia a parte de atendimento ambulatorial, mas também fiz muita prevenção, fiz grupos de gestantes. já fazendo a parte de orientação com relação a hábitos alimentares, de chupeta, amamentação, (...) eu fazia atendimento individual e em grupo. e éramos um dos únicos postos de referência para deficiente auditivo, porque nós temos uma escola, uma EMEI aqui dentro, então faziamos diagnósticos. acompanhamento, tudo, então foi um trabalho que não quiseram lá (...) era um trabalho que eu estava bastante 
envolvida. por isso eu fiquei bem dividida. vim para cá. mexi no meu horário. que eu também tenho uma sala de consultório desde que me formei. em 88. (...) Eu tinha a experiência do atendimento com essa demanda de autistas $e$ psicóticos. mas sempre individualmente. não em grupo (...) quando souberam que eu gostava de fazer esse trabalho, também individual, eu comecei a pegar casos individuais, isso quando eu cheguei." (FONOM)

Em função do questionamento de seu trabalho na UBS, Marici assumiu sua vaga no $\mathrm{HDI}$, e embora conhecesse a demanda, não estava tão familiarizada com os atendimentos em grupo. Nessa época, já na gestão Maluf, o trabalho ainda se manteve nos moldes iniciais e a equipe ainda era a mesma, o que favoreceu a ida de Marici para o HDI que, por sua vez, foi bem aproveitada, integrando vários atendimentos em grupo e também realizando atendimentos fonoaudiológicos individuais que se fizessem necessários.

Com o inicio das atividades vinculadas ao PAS, também foi designada para outra unidade, desta vez na Secretaria do Bem-Estar Social, na regional da Vila Prudente e segundo sua própria opinião, não foi tão ruim assim: 
"(...) até tive o privilégio de ser uma das melhores SURBES ${ }^{l}$. (..) o trabalho que eles desenvolveram, é interessante, mas eu sempre falaua: 'eu estou indo', eu nunca falei: 'eu sou da SURBES' (...) eu senti bastante a mudança, a principio tinha uma outra fono, nós fomos fazendo mais um levantamento... eu trabalhei com creche. nesse meio ano que eu fiquei. em 96. foi mais um diagnóstico. (...) depois eu fiz um trabalho que foi válido em todos EGJ's, que seriam hoje um espaço para gente jovem. EGJ. e todas as creches dessa região, em todas. eu fiz um trabalho de palestras para pais e educadores sobre linguagem, esse bem especifico de fono, eles queriam hábitos alimentares, toda a parte preventiva foi feita (...) isso que o pessoal elogia muito. tanto o NAE 8, que é a parte de educação da região da Vila Prudente como o SAS. eles estão muito avançados na questão de inclusão do portador de necessidades especiais dentro das creches e dentro das escolas, (...) então nós pudemos fazer toda essa parte de conscientização. de dinâmicas com todos os educadores para inclusão, então foi válido o trabalho lá (...) eu fiquei lá de 96 a 2001, mas em 2000 eu pedi licença sem vencimentos. eu teria para usufruir de 2000 e voltaria só no começo desse ano, e acabei voltando o ano passado quando eu soube que era para retornar para cá. eu acabei tirando só um ano de licença, quando eu vi que o pessoal dessa mesma equipe ia voltar. eu acabei..." (FONOM)

\footnotetext{
${ }^{11} \mathrm{Na}$ época, a nomenclatura designava as Superintendências Regionais do Bem-Estar Social, que no caso, correspondia ao escritório regional da Secretaria Municipal do Bem-Estar Social na área de
} 


\subsection{4 'É preciso tirar o avental da cabeça': os caminhos da enfermagem}

O trabalho da enfermagem constitui, talvez, o trabalho de saúde mais antigo ao lado (ou abaixo) da intervenção médica. Pode ser observado desde os tempos mais remotos, sendo que seu caráter prático tanto no âmbito doméstico quanto hospitalar predominou no século XIX, configurando-se como o conjunto dos cuidados de saúde voltados para o doente, em que se destacavam ações de higiene pessoal.

No Brasil, ao longo do século $\mathrm{XX}$, verifica-se a profissionalização de seus agentes, sobretudo do Rio de Janeiro, quando é criada em 1923 a Escola de Enfermagem Dona Ana Neri, destinada à formação de enfermeira visitadoras, inspirada no modelo americano (ALMEIDA 1984).

Em São Paulo, nesta época, o trabalho institucional da enfermagem era eminentemente hospitalar e, além das ações tradicionais e de auxilio ao trabalho médico, esses agentes eram responsáveis pela dieta dos pacientes e demais aspectos organizacionais da atenção médica No final dos anos 30 , com a reforma sanitária e a constituição dos Centros de Saúde, na Capital e no Interior, tendo o médico sanitarista como seu principal agente, a enfermagem de saúde pública como tecnologia passa a ser requisitada, demandando a criação de cursos profissionalizantes. 
Em 1942, ainda voltando-se para a medicina hospitalar do periodo, marcada pela inauguração do Hospital das Clínicas da Faculdade de Medicina da USP em 1944, é criada a Escola de Enfermagem, cujo estágio curricular junto à Faculdade de Higiene e Saúde Pública estrutura o serviço de visitação domiciliária, com a abertura dos cargos e funções de enfermeira de saúde pública, em substituição às educadoras sanitárias. Assim, a qualificação profissional acirra o processo de divisão do trabalho da enfermagem, e estes novos agentes passam a supervisionar o trabalho sanitário como um todo e também começam a desenvolver ações educativas no âmbito da rede de centros de saúde, fracionando as intervenções das educadoras, que, paulatinamente, se voltam para a visitação sanitária (PALMA, Op. Cit.).

Nos anos 60, com o processo de "privatização" da saúde brasileira impulsionado pela medicina de grupo, cresce o número de hospitais privados no Brasil, sobretudo em São Paulo, e neste contexto o trabalho da enfermagem e de seus agentes, divididos entre os enfermeiros de "alto padrão", técnicos de enfermagem, auxiliares de enfermagem e atendentes, assumem nova complexicidade e divisão.

Com relação às enfermeiras entrevistadas, Eliane e Neusa, ambas fizeram a graduação em enfermagem entre os anos de 1982 e 1985, em São Paulo, na Escola de Enfermagem da USP e na Pontificia Universidade Católica, respectivamente. Nos anos seguintes, Eliane fez habilitação em saúde pública, na Faculdade de Saúde Pública da USP e Neusa, aprimoramento em infectologia no Hospital Emilio Ribas. Quanto à especialização, Eliane fez em promoção da saúde e Neusa, em saúde pública, também na Faculdade de Saúde Pública da USP, o que confere com as informações acima, a respeito da tradição sanitarista da enfermagem em São Paulo. 
No que se refere à trajetória profissional, Eliane, após a habilitação em saúde pública, ingressou na rede pública de saúde na Região Metropolitana, em Itapecerica da Serra:

"Era um projeto especial, era um consórcio que existia entre a Escola Paulista. a USP e a região de Itapecerica da Serra. Então eles contrataram seis enfermeiros, um para cada municipio que pertencia na época ao Escritório Regional de Itapecerica, para trabalhar numa pesquisa em relação aos profissionais de enfermagem mesmo. Eu comecei a trabalhar ejá entrei nesse trabalho, nesse consórcio. Eu trabalhava no Embú, meu municipio de escolha foi o Embú. Fiquei dois anos dentro desse projeto $e$ depois prestei concurso para o Estado e continuei na mesma Unidade de Saúde. dai trabalhando pelo Estado mesmo." (ENFE)

Depois de três anos na unidade básica de saúde, "trabalhando como enfermeira da Unidade Básica", Eliane volta para sua cidade natal, no interior de São Paulo e começa a dar aula em escola técnica para auxiliares de enfermagem, onde ficou por dois anos e meio. Em 1990 prestou concurso para a Prefeitura de São Paulo:

“Em 90 foi o segundo concurso que, na época da gestão da Erundina, ela abriu para enfermeiros. E eu prestei o concurso. mas não tinha muita certeza se eu ia voltar de lá para cá. eu estava super bem lá. mas eu prestei porque era tão dificil ter um concurso na Prefeitura e eu vim para São Paulo só para prestar o concurso. Só que eles demoraram um ano para chamar, dai quando 
me chamaram. eu vim para cá para conhecer as unidades (...), porque as unidades queriam vaga para enfermeiro, eu não queria mais trabalhar em saúde pública. então as unidades que tinham vaga eram na Saúde Pública, então eu estava bem propensa a ficar por lá mesmo. não vir para São Paulo. Dai lá no meio do jornal eu vi que tinha esta unidade aqui. que era Saúde Mental. que era um projeto novo que estava se abrindo. E daí eu vim conhecer, adorei o projeto, nem tinha começado ainda. eles estavam montando. mas eu conversei com a equipe, eles estavam falando do que seria este trabalho. eu achei muito interessante, dai eu resolvi escolher. Consegui, também era uma vaga só. mas eu consegui, dai eu voltei para cá e estou desde aquela época. final de 91." (ENFE)

Ou seja, a noção de saúde pública e o trabalho da enfermagem mencionados remetem à atenção primária, área em que Eliane não queria mais atuar, embora ela tivesse optado por enfermagem na graduação com esse intuito. Na verdade, durante sua formação, o estágio em psiquiatria chamara sua atenção, ainda que fosse dentro da psiquiatria clássica. Em contrapartida, em sua permanência na UBS, entrou em contato com uma equipe de saúde mental cujo trabalho lhe parecia interessante, no momento mesmo da eclosão do Movimento Antimanicomial:

“(..) eram pessoas que estavam ligadas no Movimento Antimanicomial. fazendo parte daquele Fórum de Saúde Mental. E era uma equipe na verdade no municipio do Embú. era especifico do Municipio. O Embú tinha 8 Unidades Básicas. uma do Estado e as outras todas da Prefeitura. E essa 
equipe eram controlada pela Prefeitura e algumas pessoas pelo Estado. $e$ eles se reuniam na unidade onde eu trabalhava. então uma vez por semana eles faziam reunião lá e na minha sala, porque era a única sala que tinha disponivel era a sala de enfermagem. Eles ficavam lá e assim eu ficava sabendo de todo o projeto. tudo o que acontecia e quando tinham as passeatas. os encontros pela luta antimanicomial e tudo eles sempre me convidavam, eu ia junto e assim, mas eu não atendia. não tinha um projeto que incluisse enfermeiro dentro da rede, era mais pessoal mesmo. eu me dava bem com essa pessoas, então eu ficava sabendo o quê que acontecia, tudo, mas era mais uma ligação pessoal mesmo, não tinha um espaço da enfermagem lá dentro. A não ser durante um momento. assim. que teve um Programa de Saúde do Adolescente e que tinha um caráter mais de Saúde Mental do que de outras disciplinas. E quem fazia esse projeto dentro da Unidade Básica era uma psicóloga e uma gineco, só que a psicóloga era a que mais atendia esse programa especifico de Saude Mental. e ela me convidou algumas vezes para fazer parte, fazer algumas entrevistas com adolescentes, fazer uns trabalhos assim, mas um trabalho breve assim, foi o único momento que eu participei mais dessa equipe." (ENFE)

A partir desse contato, Eliane começou a se interessar pelo tema da saúde mental e quando surgiu a oportunidade de escolha no HDI, já tinha uma idéia do que poderia ser o trabalho e resolveu voltar para São Paulo em função disso, pois 
desejava trabalhar a partir de um enfoque único, ao contrário do que tem sido o trabalhado da enfermagem em serviços básicos de saúde:

“(..) Então quando eu vim para cá. eu vi a possibilidade de trabalhar num Hospital Dia. quando vi na relação lá de unidades que tinham vaga. uma coisa que chamava Hospital Dia Infantil de Saúde Mental. eu já imaginei o quê que fosse. Então quando eu vim aqui conhecer eu já imaginava mais ou menos que seria dentro dessa visão. Eu nem sabia que estava sendo montado um Projeto de Saúde Mental na Prefeitura. eu não sabia nada o que estava acontecendo na Prefeitura. porque eu estava em outro municipio, muito distante, tal. Quando eu cheguei aqui e conversei com as pessoas que. naquele momento, estavam aqui montando a equipe, foi daqui que eu fiquei sabendo que dentro da Prefeitura estavam montando um Programa de Saúde Mental, Projeto de Saúde Mental, que envolvia a criação dos Hospitais Dia. dos Centros de Convivência, do atendimento de crises em hospitais gerais. que é a emergência psiquiátrica. toda essa visão que era dentro do movimento mesmo antimanicomial. Eu achei super interessante, porque eu já estava em busca de um projeto mais especial para trabalhar assim. porque enfermeira acaba fazendo meio de tudo nas unidades onde trabalha e você nunca fica com uma coisa só. e eu queria ficar com um projeto só. trabalhar só com aquilo. com um foco de atenção. porque na UBS você tem que entender de saúde da mulher. saúde da criança, saúde geral. consertar aparelho, material e tudo..." (ENFE) 
Eliane integrou a primeira equipe a trabalhar no HDI da Moóca e participou ativamente de sua concepção e da implementação de suas primeiras atividades:

“(...) Então quando eu cheguei, essa idéia já tinha, (...) o quê a equipe não sabia era o quê que era um Hospital Dia Infantil. o quê que ia ser feito. porque não tinha um modelo.(...) eu cheguei exatamente no dia em que a reunião era essa: 'como nós vamos montar grade?', porque já era dezembro e em janeiro a gente já ia receber as crianças, 'que quê a gente vai fazer? : 'vai ser de quando a quando?'. Eu cheguei nesse momento, que a gente definiu assim, se o atendimento ia ser de segunda à sexta, se ia ser o dia inteiro. se ia ser meio periodo, se teria lanche ou teria almoço. que tipo de serviço que ia ser oferecido. Se, pois é. a equipe que estava no momento. se seria possivel com essa equipe montar o quê? Grupos? Se não era grupo era atendimento individual? Mas se é um hospital dia, então não dá para ser individual, porque não é um ambulatório. Dai começava aquela discussão. porque não tinha um modelo para gente copiar. não tinha nada criado no Brasil que a gente pudesse falar: 'Olha. em tal lugar se faz hospital dia e hospital dia é assim. a estrutura dele'. não tinha". (ENFE)

Ficou no HDI até a entrada do PAS, em 96 , quando foi transferida para a educação, assim como a Neusa E muito embora tal 'coincidência' possa ser entendida como uma estratégia de retorno às intervenções de saúde entre escolares, no âmbito da Secretaria da Educação, a exemplo do que já aconteceu nas organizaçōes anteriores, a idéia não era essa, pois Eliane não tinha uma atribuição 
definida nas EMEI's por que passou, exatamente como a Neusa, que também esteve em duas EMEI's antes de retornar à saúde, pós-PAS. De qualquer forma, como tinha tido a experiência com crianças no HDI, Eliane passou a estudar e tomou conhecimento das teorias e teóricos da educação, o que contribuiu, em certa medida, com o seu trabalho ao retornar ao HDI. Ao mesmo tempo, sua experiência com crianças autistas e psicóticas ajudou no reconhecimento dessas caracteristicas nas crianças daquelas EMEI's e, neste sentido, foi possível alguma intervenção, junto à criança e também com os professores.

Ainda durante o PAS, Eliane foi obrigada a voltar para a saúde e teve que ir para a periferia da zona oeste, trabalhar novamente em UBS. Muita dificuldade com o trabalho, pois não sabia "mais o que é dar vacina". Após alguns meses, conseguiu transferência para outra UBS, na região central da cidade, onde ficou por um ano e meio até o final do PAS e a possibilidade de voltar para seu "local de origem": o HDI da Moóca:

"Dai. nós voltamos todos, felizes, estouramos até champanhe no primeiro dia e desde janeiro do ano passado, quando a Marta ganhou. a gente sabia que o PAS estava com os dias contados, a gente espera pelo menos isso (risos), a gente começou a se encontrar mais oficialmente aqui no Distrito, porque eles queriam saber quais eram as equipes que iam voltar. antes de retomar as unidades. porque tinha um prazo para retomar as unidades e nesse periodo eles queriam estar organizando isso, porque o PAS acaba num dia as pessoas têm que estar no outro aqui, e o tratamento não pode parar, você não ia dar um prazo: 'bom, agora acabou o PAS, vocês ficam em casa enquanto a outra 
equipe chega para vocês retornarem'. Não, a gente tinha que estar no dia seguinte aqui. Então eles não sabiam onde as pessoas estavam, as pessoas da Prefeitura eu falo. assim. não sabiam onde estavam as equipes, a gente sabia onde cada um estava. porque a gente estava se conversando. mas eles não sabiam. Quer dizer, quando eles estavam aqui no Distrito. eles não sabiam onde estava a equipe do posto, onde estava a equipe do Hospital Dia. Entao, algumas pessoas eles conheciam, começaram a entrar em contato, a Márcia era uma delas, só que a nossa equipe, como estava se encontrando, algumas pessoas não. mas a gente tem um grupo que se encontra muito fora daqui, mas um pessoal a gente perdeu contato, mas a gente sabia que estas pessoas iriam voltar. então a gente acabou conseguindo localizá-las e falou: 'olha gente. temos um prazo para voltar, as pessoas querem saber se realmente vocês querem voltar "'. (ENFE)

Neusa, como já foi mencionado, tem uma trajetória de formação muito similar a de Eliane, somando-se ai o fato de ter feito o curso técnico de enfermagem, a a mesma dificuldade, atualmente, em relação ao trabalho da enfermagem na atenção básica, em que tal profissional faz "tudo e qualquer coisa". Logo em seguida à especialização, ingressou na rede pública estadual de saúde, por meio de concurso público para sua categoria em 1987, no Centro de Saúde da Vila Maria:

"(...) foi muito bom. porque é um centro de saúde grande, então tinham vários programas, desde a epidemiologia, saúde da criança, saúde da mulher, saúde do trabalhador, então eu aprendi muito, e o Estado naquela 
época ainda era modelo. principalmente em termos de conduta. não é essa loucura que está hoje, então a gente tinha curso de capacitação, eu fiz bastante cursos nessa época. e o Estado, assim. era uma referência. Precisava fazer qualquer coisa. tuberculose, liga para o Estado. vacina. liga no Estado, então a gente era muito atualizado. Então. nesse lugar eu fiquei três anos e meio. " (ENFN)

No final de 89 , Neusa foi comissionada para a Prefeitura, pois como liderança sindical (sindicato dos enfermeiros) não podia ser exonerada sobretudo porque que era época de eleição no sindicato, na qual Neusa concorria. Já em 90 , por ocasião do concurso para enfermeiros da Secretaria Municipal de Saúde, Neusa se efetiva na Prefeitura e passa a integrar a equipe técnica para a regorganização e integração da rede básica de serviços:

“(..) eu também recebi convite para ser comissionada, então eu fui ajudar nesse trabalho: reorganizar todo o serviço, fazer o trabalho conjunto entre unidade básica e pronto socorro. E depois, eu fui para o Distrito de Saúde de Vila Maria. ai já como assessoria, porque é a ocasião que se está dando o poder aos Distritos, poder de autonomia. de decisão. de planejamento e de dinheiro também. Então, foi a formação dos Distritos de saúde e mais o hospital vila maria, então eu entrei nessa parte ai." (ENFN)

Com a exoneração de cargo no Estado e final da administração municipal petista, Neusa, já concursada pela Prefeitura, em 1993, escolhe o HDI da Moóca: 
“(...) antes de fazer enfermagem, eu fiz curso técnico de enfermagem. e desde lá duas coisas que sempre me puxaram muito: a saúde pública e a saúde mental. não pelo o que eu vi. porque tanto no curso técnico de enfermagem. a parte de mental foi no HC. horrivel; e na graduação, que eu fiz em Sorocaba. foi pior ainda, era um manicômio enorme, você tinha um chuveiro, punha todo mundo para tomar banho e saia todo mundo e ficavam soltos lá no pátio. mas alguma coisa ali. porque se repetiu de novo esse movimento, me chamava atenção, essa área. porque o meu primeiro trabalho foi como auxiliar psiquiátrica, mas isso foi antes da graduação. Eu sempre tive uma queda por essa área. " (ENFN)

Como auxiliar psiquiátrica, Neusa atuara em um hospital particular, em São Paulo, onde cuidava desde a administração da medicação e outras atividades de cuidados e higiene até atividades em grupo, mais voltadas para a terapia ocupacional. Tal função não exigia uma formação especifica em saúde mental, apenas formação técnica em enfermagem e perfil adequado.

A partir desses relatos, é possivel perceber alguns dos caminhos trilhados pela enfermagem em São Paulo, sobretudo no que se refere à enfermagem na saúde mental, tanto em termos das tendências que assumiram essas práticas como a qualificação profissional. Neste sentido, a Escola de Enfermagem de Ribeirão Preto (USP) criou, em meados dos anos 70 , o curso de especialização em enfermagem em saúde mental ${ }^{12}$ e, recentemente, a Escola Paulista de Medicina (UNIFESP) oferece em

\footnotetext{
12 Sobre a enfermagem em saude mental, ver: LUIS (1983); MARCOLAN (1996); DALMOLIN (1998); CAMPIGLIA (1998); LABATE (1998); ESPINOSA (1998).
} 
seu programa de aprimoramento, em parceria com a FUNDAP, formação especializada em serviço social em saúde mental.

\subsubsection{Freud explica!? As mediações da psicologia e da terapia ocupacional}

A dimensão moral da loucura e seus desdobramentos individuais e subjetivos, negligenciada pelos paradigmas médicos em meados do século XIX, vinha sendo objeto de interpretação da psicologia experimental, de um lado e do conhecimento psicanalítico freudiano, de outro, sendo direcionado à interioridade não-física do sujeito, o inconsciente. Como resultado daquela cisão entre as dimensões moral e orgânica dos individuos, a psicologia, na busca de status científico, à época ainda não institucionalizada enquanto prática de intervenção terapèutica, se põe a ler “as estruturas da consciência mórbida, mas em termos da psicologia normal".

No caso do segundo campo, por sua vez, as psicologias analítica ou fenomenológica procuraram apreender a intelegibilidade de toda conduta, mesmo as tidas como mais "dementes", tentando superar os parâmetros reestabelecidos pela primeira, de normal e patológico. Nessa direção, ainda sob esses parâmetros, buscavam-se as etiologias de acordo com a causalidade, classificada a partir de fatores orgânicos e psicológicos e, desta forma, aproximavam-se as abordagens orgânica e moral.

Essa necessidade (ou equívoco) em dar o mesmo sentido às noções de doença, de sintomas, de etiologia, nas "patologias mentais" como nas orgânicas persistiu até 
pelo menos meados do século XX - e talvez até os dias de hoje -, e sua explicação, em principio, pode estar naquela busca de legitimidade cientifica como possibilidade de reconhecimento social que, por sua vez, passa a ser negociado em termos da própria construção do que é normal e do que é patológico. Ou seja, os conteúdos desses parâmetros não são fixos, ao contrário: são maleáveis e determinados de acordo com os interesses sociais predominantes (FOUCAULT 1975).

Neste aspecto, a psicologia constrói sua nomenclatura, seu discurso sobre a doença mental, e este foi sendo revisitado, a exemplo de todas as ciências e/ou disciplinas. A psicanálise, por seu turno, baseou-se na intersecção de conhecimentos da neurologia e da psiquiatria com o da eminente psicologia, dado que seu agente mais antigo era médico, neurologista. As indicações dadas por Freud quanto à formação do analista reservam um lugar especial à análise pessoal: as "qualificações ideais que o analista necessita começam a ser adquiridas em sua própria análise" (ELIAS 1999; p.74). Contudo, é apenas na modernidade que foi instituída com prática terapêutica

Assim como também eram médicos aqueles que contribuiram para a construção inicial desse campo de conhecimento no Brasil, mais precisamente no Rio de Janeiro, até meados do século XIX, tais como José Estelita Tapajós, Veríssimo Dias de Castro, Manuel Pereira de Melo Morais, Odilon Goulart, Adolfo Porchar Assis, Alberto Seabra, Raimundo Nina Rodrigues, entre outros (ANTUNES 2001).

Entre o grupo de intelectuais paulistas, encontramos vários professores de filosofia nos ginásios, escolas normais e faculdades, que teriam sido responsáveis por parte significativa da produção psicológica do periodo que legitimaria a introdução 
das inovações técnicas dos psicodiagnósticos e da psicoterapia Neste contexto, destaca-se novamente a Escola Normal de São Paulo, que em 1912 criava o Laboratório de Psicologia Experimental que desenvolvia e experimentava as medidas de inteligência, desempenho e aptidões, sendo que nos anos seguintes seria introduzida a disciplina de psicologia experimental em todas as escolas normais.

Consoante a introdução do taylorismo e da organização científica do trabalho no Brasil, introduz-se no trabalho fabril as técnicas de disciplina e controle cientifico da produção que, a partir dos anos 20 , se desdobram em um conjunto de métodos psicofisiológicos ${ }^{13}$, destinados ao preparo dos alunos do recém-criado curso de mecânica prática do Liceu de Artes e Oficios. A exemplo dessas experiências, outras seriam verificadas em diversos setores da indústria, favorecendo a mecanização e massificação da produção, já no modelo fordista de produção (CHANLET 1999).

Partindo, portanto, da capacidade técnica de avaliar as habilidades e capacidades para o trabalho, a psicologia adquire novo status social e vai imprimindo às práticas desses profissionais embasamentos teóricos para o desenvolvimento de hábitos, condutas e adaptações adequadas dos individuos à nova sociedade industrial, e que passaram a integrar um novo ramo da psicologia, denominado Psicologia Diferencial e Psicotécnica.

Tal tecnologia não logrou apenas o mundo do trabalho, mas também a educação, quando nos anos 30 foi instituído o Serviço de Psicologia Aplicada, cujas atividades destinavam-se às medidas de inteligência e capacidade mental dos escolares, impulsionadas pelo debate intelectual a respeito dos limites ou fronteiras da

${ }^{13}$ Os testes psicológicos mais utilizados foram o psicodiagnóstico de Rorschach e o questionário de Bernreuter. 
psicologia e da pedagogia, animado pela criação da Faculdade de Filosofia, Ciências e Letras da USP (ANTUNES Op. Cit.).

Esse debate intelectual sobre os diversos campos ou especializações da psicologia denotava a existência de diferentes projetos e indicava suas futuras fusões e deslocamentos, como a psicopedagogia, a psicologia infantil e a terapia ocupacional, que passa a aliar aos conteúdos anteriores técnicas de recreação e oficinas associadas às técnicas de praxiterapia, sobretudo, na reabilitação de crianças e adolescentes portadores de deficiências mentais, em instituições como as Sociedades Pestalozzi, criadas entre 1932 e 1945 em vários Estados brasileiros, a partir da ação da psicóloga Helena Antipoff; na AACD - Associação de Amparo a Criança Defeituosa -, criada em 1943, para o tratamento de crianças com paralisia infantil, cerebral e outros problemas fisicos congênitos e, também, nos hospitais psiquiátricos.

Tambem inicialmente identificada com as práticas fisioterápicas, a terapia ocupacional se emancipa no final dos anos 60 , em que se constitui como um campo "mais" autônomo, mas é apenas nos anos 80 que será regulamentada como profissão, quando seus profissionais passam a ser formalmente incorporados pelos serviços públicos de saúde, sobretudo nos serviços ambulatoriais de saúde mental ${ }^{14}$, em que assumem a condução das práticas humanizadoras e de inserção social dos pacientes com transtomos mentais (COFFITO 2002).

Jorge, o psicólogo entrevistado, estudou na PUC-SP entre 1983 e 1987, onde também fez especialização em atendimento de adolescentes, mestrado e doutorado em

\footnotetext{
${ }^{14}$ Sobre a terapia ocupacional em saúde mental, ver MÂNGIA (1999; 2000); MEOLA (2000).
} 
psicologia clinica, a partir de 1997. Recém-formado, participou do programa de aprimoramento da FUNDAP, no Hospital das Clínicas da USP, no Instituto Central, na área de Otorrino.

Em 1989, prestou concurso na Secretaria de Estado da Saúde e trabalhou em um ambulatório de especialidades na Freguesia do Ó, onde ficou por um ano. Mais ou menos na mesma época, ingressou na Prefeitura e passou a trabalhar em um Centro de Convivência de Saúde Mental, em Itaquera, tendo participado da montagem do serviço, aí permanecendo um ano e meio. A seguir, foi convidado para integrar a equipe técnica da área de saúde mental como assessor de saúde mental da regional 4:

“(...) mas não gostei. Meu negócio, eu gosto de atender. não gosto de ficar de assessoria não. (...) Eu prefiro atender. E ai na época estava tendo uma transição, porque aqui era uma antiga clínica de saúde escolar, e que ia virar, por umas negociações técnicas e politicas. ia virar um Hospital Dia Infantil. e algumas pessoas que eu conhecia vinham para cá. Então quando teve uma remoção eu escolhi vir para cá.. " (PSIJ).

No processo de remoção dos profissionais da saúde do Município, Jorge opta pelo HDI, no final de 1991, onde permanece até a entrada do PAS, em junho de 1996, quando vai para o Centro de Referência em Farmaco-dependência do Parque Dom Pedro:

"(...) Não gostava, demorou muitos anos para eu engrenar, primeiro que assim. não era minha escolha, (...) O primeiro ano lá foi muito duro, (...) Depois. no decorrer, eu comecei a me envolver. (...) Cinco anos que eu fiquei 
lá (...). Ai. tambèm eu acho que aprendi a me envolver mas sem me entregar totalmente..." (PSIJ)

Em junho de 2001, junto com os demais profissionais, Jorge volta para o HDI e desenvolve funções como psicólogo e auxiliar de chefia:

“(..) a gente manteve amizade durante todos esses anos, a maior parte das pessoas, quem voltou. a gente se encontrava. ia nas festas de aniversário, saia. Porque quando a gente saiu, a gente manteve contato, ainda tentamos fazer alguma resistência junto com as mães. lá na comunidade do Padre Júlio. aqui na Moóca. fizemos algumas reuniões tal: depois algumas mães. uma das mães queria que eu fosse diretor de uma das escolas que as crianças freqüentavam. eu não quis. E durante muito tempo eu continuei referência, porque mesmo algumas mães iam me procurar lá na farmaco. mesmo eu não sendo mais daqui, para conversar, para trocar idéia, não para atendimento. mais uma referência mesmo. E então quando se falou em voltar. logo pensei em voltar para cá. principalmente se voltasse a maior parte das pessoas da equipe. Eu sempre quis voltar para cá. eu nunca me conformei de ter saido daqui, eu sinto aqui como se fosse minha casa. eu nunca me conformei de ter saido..." (PSIJ)

Márcia Innocêncio, terapeuta ocupacional, fez a graduação na Universidade Federal de São Carlos, entre 1984 e 1987 e, em seguida, fez aprimoramento em psiquiatria no Hospital das Clínicas de Ribeirão Preto. Quanto às especializações, 
iniciou a primeira, de terapia ocupacional em psicodinâmica, em 1989, no Centro de Estudos de Terapia Ocupacional da Escola Paulista de Medicina e cursou ate 1991, pois seu interesse se voltou, nessa mesma época, para coordenação de grupos e análise institucional, cursos que realizou no Instituto A Casa, entre 1991 e 1993.

Ainda no aprimoramento, prestou concurso na Secretaria de Estado da Saúde, no final dos anos 80 e continuou trabalhando na enfermaria e, depois, no ambulatório do Hospital das Clínicas. Depois, concursada pela Prefeitura em 1991, trabalhou no hospital dia adulto de Pirituba em 1992. Quando começou o PAS na rede, foi transferida para o Centro de Convivência de Guarapiranga e quando as atividades do PAS iniciaram no Centro de Convivência, foi novamente transferida, desta vez para o HDI da Moóca:

“(...) eu fui transferida para cá. Ai eu conheci esta equipe, fiquei pouco tempo aqui, porque logo começou o PAS aqui, então eu não sou desta equipe de origem. Conheci esta equipe pelos grupos de trabalho do HD. enfim. dos encontros de hospitais dia que tinham na época (...)" (TOMI)

Sua última parada durante o PAS foi no Centro de Farmaco-dependência do Parque Dom Pedro, onde conheceu o Jorge e a Ana Maria, assistente social, ambos atuais integrantes da equipe do HDI, cujo trabalho que desenvolviam direcionava-se para $o$ atendimento a grupos de familias, pois seu interesse sempre foi por grupos:

“(...) eu sempre fiz grupo de terapia ocupacional e fazia o grupo verbal com uma psicóloga. Então, eu acabei entrando (nesse grupo com o Jorge) pela experiência com grupos (...)". (TOMI) 
Quando acabou o PAS, Márcia Innocêncio não quis voltar para o HD de adultos, pois seu interesse já tinha se voltado para o HDI. Anteriormente, teve consultório e trabalhou em clinica particular, de onde vinha seu contato com criança, especialmente com grupos de pais:

"(..)Eu acho que nas outras equipes em que eu trabalhei, o trabalho com familia era um pouco mais claro. (...) Por exemplo. no farmaco. Paciente era triado. duas pessoas triavam os pacientes e na outra sala, duas pessoas triavam a família. ai se o paciente aderia. a familia passava para um grupo de orientação de quatro semanas. Durante essas quatro semanas. as duas terapeutas daquele grupo de orientação percebiam quem tinha alguma demanda para participar de grupo de familia mais psicoterápico ou quem precisava de um atendimento individual ou quem não tinha demanda nenhuma, dos familiares. A gente tinha um fluxo. No hospital dia de adulto também a gente tinha um fluxo, a familia entrava. ela tinha um atendimento mensal com o terapeuta de referência e ai tinha o grupo de familia, eram dois grandes grupos e as familias participavam. (...) As crianças das quais eu sou referência. eu atendo as familias, mas não é todo mundo que é referência que gosta, que atende. Não é uma conduta do HD. Tem criança que entrou na terça, a mãe já entrou no grupo de familia na outra terça, meio automaticamente. (...) Eu acho que ter entrado gente nova como eu e a Ana. que gostamos bastante de trabalhar com familias. traz para a equipe aquela vontade de discutir. Então, gente nova. idéias novas, como a intervenção 
precoce. enfim. loda a idéia de inclusão escolar e pouca gente para trabalhar. a gente acabou deixando meio de lado." (TOMI)

\subsection{Compreendendo a coreografia: o conteúdo do trabalho}

A grade de atividades atual do HDI, como já referida, contempla atendimentos de caráter ambulatorial e intensivo, este último correspondendo à modalidade Hospital Dia $\dot{E}$ sobre esses atendimentos que faço uma 'incursão' para que seja possivel desvelar os objetivos das intervenções e sua articulação aos saberes sobre as quais se pautam.

Cabe ressaltar que a maior parte das atividades foi mantida desde a implantação do HDI, e seus formatos permaneceram durante o PAS, embora com objetivos e encaminhamentos diferentes, sendo que a disposição dos horários e a freqüência das crianças ao serviço, à época das entrevistas, ainda eram aquelas definidas nos tempos do PAS.

As atividades realizadas em grupo são o eixo principal sobre $\circ$ qual se organiza a assistência oferecida pelo HDI e delas decorrem, na medida do necessário, atendimentos individuais. Em geral, as atividades de grupo são realizadas em parceria e também, em alguns casos, as individuais, mas sempre a partir de um mesmo fio condutor:

"Basicamente. a linha é psicodinâmica. assim se é psicodrama, se é Gestalt. tem que ter uma compreensão da psicodinâmica, só que quando vem para o 
processamento da equipe. nós procuramos dar o embasamento psicanalítico mesmo, porque trabalhar com o autismo, com a psicose. nós não trabalhamos num entendimento de mudança de comportamento. de reforço, punição, de educação num sentido de mudança de hábitos. Nós promovemos algumas mudanças de hábitos dentro de uma compreensão da psicodinâmica. da história dessa criança e do seu meio familiar. E ai trabalhar com toda a questão. qual foi o problema, uma falha da simbolização que deveria ter havido, falta na construção do sujeito. Claro que atualmente a gente não faz talvez o erro que já foi feito anteriormente de dizer 'isso é origem psíquica, é psicogenética ou é neurológico e acabou', não. Nós estamos trabalhando com a psicodinâmica que está instalada, de onde veio. é claro que conforme o diagnóstico pode ter um prognóstico melhor." (PSIMR)

A citação acima revela, claramente, o referencial teórico adotado pela equipe para conduzir o atendimento a que se propõe. Ao longo desse trajeto, é possível identificar que foram sendo feitas negociações acerca do entendimento que tinham a respeito do objeto sobre o qual intervinham, o que implicou na ruptura com o modelo de atenção em saúde mental tradicional, cuja matriz teórica baseava-se, fundamentalmente, na compreensão orgânica do processo saúde-doença, que se traduziu em práticas assistenciais de intervenção focalizadas, exclusivamente, na sintomatologia e na assistência hospitalar.

Como mencionado anteriormente, as transformações do modelo de assistência em saủde que vêm se consolidando desde a Constituição de 1988 e da lei 8.080/90 - 
que estipulou os princípios do Sistema Único de Saúde - imprimiram ao campo da saúde mental a necessidade de reflexão sobre a saúde-doença como processo social e, coerentemente, a conseqüente proposição de um modelo de atenção em saúde concretizado em práticas assistenciais de desospitalização (PITTA-HOISEL Op. Cit.; AMARANTE 1995).

Enquanto processo de trabalho, as atividades aparecem, em geral, ao longo das narrativas, associadas aos nomes dos profissionais que as realizam, o que confere a elas um caráter subjetivo e de integração. Podem ser consideradas, ainda, como um mosaico, segundo a forma pela qual cada profissional relatou sua atuação e composição na equipe. Ao final de cada entrevista, foi possivel recompor a grade geral de atendimentos, localizando os mesmos e seus horários e dias correspondentes.

A triagem, por exemplo, no momento das entrevistas, não estava acontecendo devido à falta de funcionários, tanto administrativos como técnicos, mas elas são conduzidas, geralmente, pelas médicas, que se dividem entre os dois períodos, em parceria com as fonoaudiólogas ou com as assistentes sociais, ou mesmo pelos profissionais não médicos, com a retaguarda dos psicólogos e das psiquiatras, para o aprimoramento do diagnóstico, uma vez que um diagnóstico adequado favorece um prognóstico melhor e um encaminhamento correto. Ou, ainda, a identificação de comorbidades que precisem ser consideradas.

Em termos técnicos, os diagnósticos nas triagens envolvem o chamado 'raciocinio clínico' que consiste na avaliação dos casos, segundo a correlação entre os sinais e os sintomas apresentados ou identificados no decorrer do tempo e entre estes e o histórico de vida dos pacientes e a "fase da doença". Nos casos em que os sinais 
não são claros, há a necessidade do diagnóstico diferencial da fonoaudiologia ou da psicologia tanto para um atendimento ambulatorial breve da fonoaudiologia por exemplo, como para o encaminhamento às oficinas terapêuticas ou atendimentos psicoterapeuticos mais direcionados. Em casos de crise manifestada no ato da triagem, o raciocinio clínico se coloca ainda mais imperativamente.

As refeições, lanches e almoço, acontecem de segunda à quinta feira, para as crianças dos dois períodos, e estas atividades são acompanhadas por todos os técnicos e auxiliares de enfermagem, de acordo com uma escala. As refeições têm como objetivos, além da alimentação em si, verificar a dinâmica das relações das crianças entre si e das crianças com a comida, favorecendo algum nível de sociabilidade, pois a tendência da maioria das crianças é o isolamento ou a introspecção, sobretudo nos quadros mais regredidos de autismo. São nesses momentos que alguns padrões de comportamento podem ser observados e compreendidos e levarem a intervenções mais pontuais ou até mesmo a mudanças de atitudes e percepção acerca de necessidades específicas de determinadas crianças. 
Nesse sentido, as refeições são atividade meio e atividade fim, a partir das quais outras são desenvolvidas ou adaptadas, ao mesmo tempo em que demarcam limites, inclusive entre as demais atividades terapêuticas pelas quais as crianças passarão, e certa regularidade que revela a vida cotidiana ${ }^{15}$, a rotina que fornece certo senso de realidade e, inclusive, a possibilidade de romper com ela ou reinventá-la. Após cada refeição, as crianças recebem os cuidados de higiene, em que são trabalhados os hábitos de escovação, por exemplo.

As oficinas terapêuticas distribuem-se em: oficina de estórias, oficina de artes, oficina de música, oficina do movimento, oficina de esportes, espaço livre, oficina de estimulação, em duas versões, uma mais voltada para o corpo e outra para a linguagem e a oficina cultural e o que orienta a dinâmica das atividades é aquilo que foi definido como proposta para cada espaço.

A oficina de estórias, realizada com duas abordagens diferentes, busca a revelação de simbolizações coletivas, de representações sociais, por intermédio de dramatizações de estórias clássicas da literatura infantil ou mesmo das mais modernas, como a do Rei Leão, da Walt Disney, que são 'encenadas' sempre, pelos técnicos com a participação das crianças. Numa linha psicanalítica, trabalha com os mitos ou arquétipos, a partir dos quais é possivel uma aproximação aos mecanismos psíquicos das crianças. Assim, as estórias encenadas ou mesmo aquelas construídas são o elemento mediador entre as crianças e a realidade e entre as crianças e os próprios profissionais, que ficam atentos a todas manifestações individuais ou relacionais, onde

\footnotetext{
15 Sobre esta noção, alguns autores contemporâneos da sociologia e da história, estrangeiros e brasileiros, como Agnes Heller, Henri Lefebvre, José de Sousa Martins tem-se detido nas últimas décadas, constituindo linhas de pesquisa e mesmo disciplinas.
} 
se esboce uma construção de sentido. Neste caso, o aspecto da repetição também se coloca como parâmetro de realidade.

A oficina de artes, presente no começo do HDI, assumiu um outro caráter: antes objetivava a confecção de um desenho, uma colagem, uma escultura, dependendo dos recursos materiais disponíveis e do interesse do grupo ou de cada criança e o processo de elaboração obedecia certa ordem para chegar a um produto final. Em um grupo de crianças menos regredidas era possivel algum nivel de integração, entre as tarefas realizadas individualmente. Atualmente, o recurso artístico passou a ser utilizado no chamado Grupo de Estimulação ou Oficina de Estimulação, em que as atividades de colagem, de pintura, de desenhar são atividades meio para a grupalização, para o desdobramento em outras atividades conexas, como brincadeiras, o preparo e degustação de algum prato, que amplia ainda mais a sociabilidade e confere certo senso de continuidade e articulação das tarefas.

Um segundo grupo de estimulação tem uma proposta diferenciada, que é trabalhar a percepção corporal e identificar nesse processo algumas dificuldades e disfuncionalidades, através do próprio contorno corporal. São feitas, por exemplo, massagens com óleos em ambientes montados especialmente para o relaxamento e aconchego da criança. A música compõe o ambiente, assim como colchonetes e pedaços de carpetes e lençóis e essa composição partilhada pelas crianças já trabalha a própria ritualização. Algumas crianças têm muita resistência ao toque, sendo que algumas partes do corpo não conseguem se deixar tocar, assim as massagens são relativamente rápidas, mas buscam uma aproximação fisica. Dada a dificuldade de 
concentração, caso sejam atraidas por outros estímulos, como a própria música. partem para outra atividade, por exemplo, dançar e cantar.

A oficina de música é um espaço em que se tenta recuperar ou mesmo proporcionar alguma funcionalidade, a partir de estímulos sonoros, pois a música $\dot{e}$ um grande recurso terapêutico. Além do contato das crianças com o som, com alguns instrumentos musicais, com outras crianças, busca estimular também alguma vocalização, pela música e pelas brincadeiras que a acompanham Neste aspecto, também é uma atividade meio. Apesar da falta de recursos materiais - brinquedos e instrumentos musicais que se quebram, freqüentemente, e nem sempre são repostos-, é possivel verificar o efeito que a musicalidade tem sobre as crianças, sobretudo entre aquelas que não falam, de quem são flagrados balbucios e de outras que começam a cantar baixinho. Outro aspecto revelado é a forma como as crianças manipulam os objetos e lhes atribuem significados ou reconhecem sua função. No caso de crianças mais regredidas, estas não fazem a diferenciação dos objetos e os manipulam do mesmo jeito, abrupto. Então, busca-se observar essa forma de manipulação para dai, também, ser possivel trabalhar e estimular 'os sentidos dessa percepção', mas a idéia geral é a comunicação.

A oficina do movimento é supervisionada por uma profissional de fora, fruto de uma parceria com a Secretaria de Cultura, em que são contratados 'oficineiros', cujos projetos podem ser desenvolvidos em qualquer âmbito dos serviços da Prefeitura No caso, esse trabalho de expressão e consciência corporal acabou voltando-se para essas crianças e também para os profissionais do HDI, para que seja trabalhada a relação criança/espaço e, assim, facilitar a percepção corporal por 
intermédio da sonoridade e do ritmo, que por sua vez, contempla aspectos de coordenação motora, equilíbrio e até a propriocepção.

O Espaço livre ou atividade livre era um espaço em que cada criança escolhia - que queria fazer e com o que brincar. Inicialmente, esta falta de direção desestruturou tanto as crianças como os técnicos, pois todas as crianças ficavam na sala, com seus objetos, gritando, furiosos, sem conseguirem entender minimamente o sentido do que estavam fazendo, sem comunicação entre si, o que gerou forte cansaço para todos e acirrou ainda mais a introspecção e a falta de integração do grupo. Esse espaço foi desmembrado em dois, entre crianças com maior dificuldade de interação e aquelas mais comunicativas e os técnicos também se dividiram, facilitando, assim, o aproveitamento desse momento para ambos (crianças e profissionais). Entre as crianças que brincam, são usados os brinquedos que favorecem a interrelação, por exemplo, a bola ou bonecas. Então, passou a ser um espaço para brincar e partilhar as brincadeiras.

A oficina de esportes corresponde basicamente à educação fisica, e aqui também conta com um profissional de fora, uma professora do Centro Esportivo, próximo ao HDI, para coordenar as atividades, que consiste basicamente em ginástica, na sala de judô do $\mathrm{CE}$, no tatami, e corridas e caminhadas nas imediações ou mesmo idas à quadra para algum trabalho com bola, jogos e brincadeiras. Nessa oficina, os profissionais do HDI assumem um papel de co-responsáveis, o que facilita outros "trânsitos" e olhares sobre a atividade.

A oficina cultural prevê saídas para passeios com os familiares juntamente com as crianças para lugares como o zoológico e o objetivo é promover a integração 
dessas crianças com a familia em espaços públicos, onde normalmente vão ter "um comportamento esquisito" perante às outras pessoas, de quem esperam um olhar de estranhamento. A idẻia é estar com o familiar neste momento e tentar trabalhar alguns aspectos desse estranhamento, para que seja possivel entender esse movimento e amenizar o sofrimento, a vergonha, os constrangimentos, ao mesmo tempo em que as crianças são colocadas 'à mostra', não no sentido de uma exposição gratuita, mas de busca pelo espaço da diferença e do respeito.

Esses espaços abertos, fora da instituição, buscam contemplar, em certo sentido, a perspectiva da inserção social, preconizada pelo novo modelo de atenção em saúde mental. Pode ser considerado, também, um momento em que os próprios profissionais exercitam formas de compartilhamento da assistência que oferecem e, portanto, do trabalho que realizam.

Com a intenção de cada vez mais abrirem o HDI para a comunidade, mesmo para os técnicos de outras unidades, são concebidas e realizadas as atividades intersecretariais, como a inclusão escolar, que consiste em um trabalho direcionado a professores que tenham criança(s) com transtorno global de desenvolvimento dentro de uma sala comum Podem, também, acompanhar essas crianças, inclusive as do HDI que tiverem em condições, para uma classe especial, quando não se tem a possibilidade de inclusão em uma sala comum. Este trabalho è realizado em parceria com a rede municipal de ensino e, em alguns casos, até com escolas particulares, e busca, ainda, a integração da rede da educação com a rede da saúde. Com este objetivo, o HDI promoveu um evento no dia 23 de outubro de 2002 , o $2^{\circ}$ Fórum do Programa de Inclusão Escolar, com a participação de todos os 13 NAE's da cidade - 
Núcleo de Ações Educacionais - e com todos os HD's e serviços especializados infantis.

No caso da inclusão escolar, as assessorias à rede de educação objetivam multiplicar "os olhares" no sentido da identificação dos primeiros sinais, assim como o diagnóstico precoce, voltado para o pessoal das creches e da rede básica de saúde, que recebem crianças de 4 a 6 anos e os bebês que chegam para os pediatras, respectivamente. Neste sentido, orientam todos os sinais para os quais esses profissionais têm que estar atentos e, com isso, um daqueles serviços jả encaminhou um bebê de 8 meses para triagem e também está com uma criança de 3 anos de idade em tratamento, cuja perspectiva de recuperação e de diminuição dos agravos à saúde como um todo aumenta.

Revela-se, então, a preocupação que o HDI tem em promover a saúde mental de quem sofre transtornos mentais, oferendo uma melhor qualidade de vida, inclusive para a familia. Assim, os grupos psicoterapêuticos destinam-se também aos familiares, em geral, às mães, porque a proposta geral é de implicação da familia nos sintomas da criança ou na falta de simbolização, para que se amplie ainda mais as possibilidades de melhora na relação mãe/criança e facilite a inclusão escolar. Ou seja, ao promover o entendimento da familia a respeito das dificuldades da criança, essa convivência poderá ser melhorada, uma vez que a mãe possa mediar a relação das crianças com os demais membros da familia.

A família (as mães) é muito requisitada, mesmo ainda estando pouco envolvida no HDI, e acabam sendo encaradas como pacientes também, pois: 
"(..) existe um movimento psiquico. acho que em cada um de nós. ou então não existiriam os asilos desde que foram criados, os manicômios. existe em cada um de nós um mecanismo de dizer o problema está lá e não aqui. 'Cá em mim nada, vai tudo bem. obrigada, não fosse este problema no fulaninho': $e$ que a gente faz o trabalho inverso de implicar. reimplicar as questões dos seus filhos, que eles possam ir a diante. "(PSIMR).

Então, conta com a participação das mães, em sua maioria, no grupo de familiares, que são grupos mais interpretativos, psicanalíticos, e em alguns casos o atendimento ao núcleo familiar, ou seja, as chamadas terapias vinculares, em que a criança é ouvida, o familiar é ouvido, nas quais se busca o entendimento da dinâmica familiar e uma construção de sentidos.

Outro facilitador dessa relação familiar-criança e da conexão entre familia e HDI são os Técnicos de Referência, cujo trabalho consiste na designação de determinado profissional para estar mais atento a 3 ou 4 crianças, com as quais tenham maior afinidade e com quem tenham estabelecido melhor vínculo. Assim, percebem mais a dinâmica da criança e da familia e respondem pela 'evolução' de seus quadros junto à equipe e também junto à familia e escola, que passa a identificá-los como o ponto de contato quando têm algumas dúvidas ou precisam de alguma informação da criança ou do serviço.

Outros atendimentos especificos, por sua vez, como a fonoterapia, que consiste em um trabalho de linguagem, não uma fonoaudiologia mais tradicional acerca dos problemas articulatórios, refere-se, principalmente, à recuperação e a 
reorganização da criança para a linguagem. Pode ser individual e acontece de qualquer forma o tempo todo nas atividades em grupo.

Um trabalho de estimulação global do desenvolvimento também pode ser realizado individualmente, assim como atendimento individual de terapia ocupacional, cujo objetivo è tentar um vínculo com as crianças bem regredidas, que não consigam nenhum nivel de contato ou que necessitem de treinos bem pontuais para a realização das atividades de vida diária, para depois serem encaminhadas aos grupos. A psicoterapia ou grupo terapêutico é direcionada para as crianças ou pré-adolescentes que tenham algum repertório mais organizado, para os quais sejam identificados os beneficios a serem alcançados com esta intervenção.

A Comissão de Ensino e Pesquisa, constituída por alguns dos profissionias, não é uma portaria ou uma instância formalizada institucionalmente. É uma organização interna do HDI desde a sua implantação. Com a preocupação com o desdobramento da formação de futuros profissionais, o HDI sempre recebeu estagiários, e para que houvesse uma organização e sempre uma mesma medida, estabeleceu-se a Comissão, para discutir as visitas à Instituição, os diversos tipos de estágios: aqueles encaminhados pela Prefeitura e os contratados diretamente, entre HDI e as instituições escolares ou assistenciais e de pesquisa. Atualmente, contam com estagiários de psicologia, de terapia ocupacional, técnicos de enfermagem, e tem uma solicitação para estagiários de fonoaudiologia. E também há previsão para mais uma modalidade de estágio de psicólogos, remunerado, a partir de concurso pela Secretaria, que já existiu antes, entre 94 e 96 , quando realizavam o processo seletivo com prova escrita, com dinâmica de grupo e entrevistas individuais. E essas pessoas 
têm 20 horas de dedicação ao estágio e são pagos pela Secretaria da Saúde, têm um supervisor intemo responsável, diferente dos que vêm direto da entidade de ensino, que têm um supervisor da própria Universidade.

A partir desta reconstrução do fluxo e da grade de atividades foi possivel pensar acerca da organização do trabalho e do processo de produção da assistência em um Hospital Dia Infantil em Saúde Mental, que como já referido, é referência para este tipo de atendimento, no Município de São Paulo.

A organização do trabalho descreve o próprio percurso do usuário dentro da unidade, em que os saberes técnicos e a realização das atividades (de recepção, direção e programas) parecem estar bastante afinados, obedecendo a uma hierarquia formalizada institucionalmente: corpo administrativo - chefes e auxiliares; corpo técnico - equipe multiprofissional e auxiliares de enfermagem; corpo de apoio segurança, cozinheira e pessoal da limpeza.

Quanto ao processo de produção da assistência, pode-se identificar como instrumentos do trabalho a boa estrutura fisica do HDI e localização, o que pode funcionar como fator de acessibilidade ao serviço; a articulação que estabelecem entre os saberes técnicos e os saberes operantes, por meio do contato com estagiários e instituições de ensino superior e, também, de ações intersecretariais como no caso da inclusão escolar. Entretanto, a própria reconstituição da memória do serviço pelos profissionais permite identificar esse movimento de negociação e conexão entre os diferentes saberes, cujas hierarquias, autoridades técnicas e novas hegemonias vão se revelando. Estes aspectos serão discutidos no próximo item 


\section{$4.5 O$ 'sentido' do trabalho coletivo em saúde mental}

Para a reflexão das categorias analíticas que orientam o presente estudo, a saber: divisão técnica do trabalho, autonomia profissional, saberes, equipe multiprofissional de saúde e também para a compreensão do significado que os profissionais atribuem ao trabalho que realizam e ao trabalho em saúde mental, passo à discussão de como as subjetividades dos profissionais e suas especificidades técnicas operam, em conjunto, na composição da assistência oferecida.

No que se refere às composições profissionais, além daquelas existentes entre os técnicos do HDI, existem também as constituidas com profissionais de outras Secretarias e com estagiários das áreas de psicologia e terapia ocupacional, que sempre compuseram nas atividades de assistência do HDI, o que significa mais gente preparada para estar com essas crianças, mas estes nunca ficam sozinhos e nem coordenam nenhuma atividade. E mesmo que não estivessem tão presentes no momento das entrevistas, são mencionados e sua participação estará sempre sob orientação e supervisão dos técnicos:

“(..) Só quando a gente. já no andar de vários meses desse estagiário. estando aqui na Unidade, a gente percebe a maturidade desse estagiário e a possibilidade dele desenvolver um trabalho pontual. Porque também acaba sendo um compromisso com data marcada também por parte do estagiário, sendo que é um trabalho, geralmente, de longa data" (PSIMR) 
Neste aspecto, o contato com estagiários significa, ainda, para alguns dos entrevistados, a possibilidade de conexão com a academia e com os novos conhecimentos e tecnologias, constituindo-se em alternativa para a atualização técnica e teórica, sobretudo nas discussões dos casos, em que os estagiários contribuem com essas informações e nesse debate se revelam as elaborações acerca das práticas vivenciadas no exercício do trabalho:

“(..) Eu acho importante, faz a gente estudar mais, faz a gente procurar mais. faz você trocar, é muito importante estar compartilhando experiências, faz você também estar buscando, (...) não abrimos esse ano por causa da sobrecarga, porque o ano que vem eu vou tentar sair de alguma atividade para poder também está dando essa supervisão, porque está puxado. eu tenho vários individuais (...) Com o supervisor mesmo também, parece que vai ter uma parceria, você pode também estar fazendo curso. tem uma contrapartida... é bem interessante (...) eu sempre tive, eu abro também para o estagiário de psicologia entrar assim nesses atendimentos individuais.(...). Ele entrava e depois nós discutiamos o caso, ele levava... foi bem interessante. (...) muitas vezes a criança quando vai conseguindo ter o minimo assim de agüentar ficar no refeitório e está conseguindo lidar um pouco melhor, a gente acaba levando. (...) ai o Ricardo com a psicóloga também estavam entrando. então tem essas... trocas, também a de T.O., eles estão presentes em todas as atividades, mas em termos até de eu parar para conversar, de discutir, meio que dar uma supervisão, eu faço para esses casos, para esses momentos que 
eles entram comigo, onde eu me acho mais na responsabilidade de estar dando uma devolutiva do que foi feito, do que foi trabalhado" (FONOM)

Há, ainda, previsão de novas modalidades de contrato e parcerias para estagiários em diversas áreas, inclusive para a área técnica de enfermagem De todo modo, o que vale ressaltar é esse aspecto dialógico da relação profissional-estagiário, com a qual ambos podem se beneficiar; reflete a própria dialética entre os saberes técnicos e operantes, na qual cada um tem a possibilidade de aprender enquanto ensina. O profissional não é responsável pelo estagiário, e sim, responsável pelo serviço diante da situação de estágio e da instituição de ensino contratante; o estagiário, por sua vez, em processo de formação, pode exercitar (uma) prática da qual deverá extrair subsídios que ampliem (suas) reflexões de cunho acadêmicas, e neste caso, torna-se um mediador entre o profissional-professor e o profissional do serviço.

Quanto às inter-relações entre os profissionais do HDI, as narrativas, de forma geral, apontaram para duas modalidades de relacionamento que estão profundamente ligadas: os laços pessoais, estabelecidos com base na boa qualidade de suas relações fraternais, sendo "alimentadas" pelas afinidades técnicas e éticas, que foram construindo e partilhando ao longo do tempo; e os laços profissionais, fortalecidos pela boa qualidade de suas relações afetivas, que favoreceram a integração e a comunicação do grupo em direção a um projeto comum: oferecer assistência em saúde mental de qualidade, entendendo-a como direito. 
Todavia, esse elevado grau de intimidade e amizade poderia constituir-se em uma armadilha no exercicio profissional, e ai o risco seria o de se tornarem "apenas" amigos, tumultuando ou mesmo atrapalhando a dinâmica profissional e comprometendo a assistência prestada. Entretanto, no caso destes profissionais, tal proximidade pessoal é tomada como instrumento de trabalho e facilita o desenvolvimento e aprimoramento das relações profissionais e do próprio trabalho, e servem como um bom paràmetro para o estabelecimento das relações com os usuários do serviço, relações essas que são profissionais e humanas. Longe de terem atingido a perfeição, estes profissionais demonstraram disponibilidade para tal empreendimento, sem a qual a mudança de modelo de atenção em saúde mental - ou em saúde, de forma geral -, não se efetivará.

Desta forma, como as atividades são essencialmente realizadas em parceria, a composição profissional de cada oficina, por exemplo, não é apenas determinada pela formação diferenciada ou por especificidades técnicas, mas também pela subjetividade de cada um, pelas habilidades e afinidades que têm com os objetivos e dinâmicas das oficinas e, também, entre o grupo de profissionais que vai conduzir o trabalho:

"(...) eu gosto de trabalhar com grupos." (TOMI)

“(..) eu fazia várias atividades, porque eu gostava muito de oficinas terapêticas. que era uma coisa que muitas vezes o pessoal que era mais da minha área não fazia. Porque achava que era uma coisa mais de terapia ocupacional, não estava tão acostumado, porque a formação de psicólogo vai muito para uma coisa 
mais psicoterápica. né? Não tanto grupos abertos, oficinas abertas tal. Então. na verdade, na época. eu gostava muito. " (PSIJ)

Há casos de profissionais que não se identificam pessoalmente com algumas oficinas de que participam, mas o fazem em função da necessidade objetiva, por conta do grande número de crianças, em contrapartida ao número reduzido de técnicos, atualmente:

“(..) eu fazia uma oficina que, a principio. eu achei que eu não me encaixava muito que é a oficina de artes, porque essa situação de eu ficar sentada. (...) mas eu me dei conta só agora, porque eu acabo fazendo a opção de uma coisa como espaço livre, atividade cultural. sair, ir para o parque, eu sou muito mais ligada a movimento mesmo, mas acho que eu estou mais segura. eu sinto que eu estou bem diferente agora. estou mais segura com criança mesmo. . (ENFN)

“(..) faço coisa que eu não gosto, que é a atividade fisica, não tenho nenhuma simpatia ou interesse. Eu não gosto de nada de abordagem corporal, nada, nunca gostei. mas enfim. eu faço tambèm pela questão do coleguismo, tem. precisa, então vamos lá. É um desprazer, então eu tento circular de outro jeito, nem que for para ficar ajudando a levar para o banheiro. porque eu não gosto dessas coisas corporais e aqui tem bastante." (TOMI)

Por outro lado, há o reconhecimento de que os saberes especializados são necessários para que sejam identificadas diferentes formas de aproveitamento das 
situações, propiciando várias intervenções, desde o refinamento do diagnóstico até o encaminhamento adequado para outros atendimentos mais pontuais que estiverem disponiveis:

"(..) acho que tem uma coisa do especifico tambèm de AVD. que eu gosto. porque aqui a gente não trabalha com isso especificamente. criança deficiente mental precisa só de treino de $A V D$, mas todas as crianças têm um prejuizo de AVD e eu acho legal estar por perto. Cabe olhar para os hábitos alimentares mais do que alimentação e eu gosto também pela questão do afeto, do cuidado. da maternagem que esses espaços possibilitam. " (TOMI)

"(..) como eles deram para mim essa opção de escolher mesmo. essa possibilidade de escolha. então eu fui optando... mas eu tinha essa visão. do que tinha a ver e muitos atendimentos individuais para aquelas crianças, isso ainda mantém, não para todos, mas aquelas que você percebe que um trabalho individual, pontual em cima de alguns...para criança que está naquele momento da linguagem. para começar a desabrochar. que tem que estar o outro construindo junto. e muitas vezes no individual. no dual mesmo. ou então aquelas até que precisavam da especificidade, precisavam do trabalho mais ambulatorial. são poucas, não $\dot{e} o$ articulatório. aquela questão do exercicio que você faz em UBS. que faz no consultório. aqui a demanda realmente não é essa, mas alguns casos você vê essa necessidade" (FONOM) 
“(...) A Marici é mais técnica nesse aspecto (risos), em compensação. voz a Marici fala comigo, tá? "Como é que é aquilo mesmo?". Se for isso, nem pensar. Eu só vejo o grosso e a Marici: "tá, eu vejo, mas tambèm não sei mais muito disso não". Então. eu acho que... o Jorge tem formação em grupo, uma coisa mais assim. pede para o Jorge, mas às vezes uma leitura. que eu quero pensar mais com a cabeça. vou falar com a Márcia Innocêncio. então a gente tem muito isso. Uma coisa mais de linguagem, de cognitivo, vêm falar comigo: "olha, como é que tá o desenvolvimento cognitivo?" (FONOL)

Desta forma, há profissionais que conhecem mais de grupo de familia, aqueles que conhecem mais de oficinas terapêuticas ou quem conheça mais do atendimento da psicoterapia ou de fonoterapia, e nestes casos, podem assumir os atendimentos individuais que se mostrarem necessários ou vão estar dando o direcionamento das atividades e compartilhando com os demais profissionais formas e conteúdos do que deve ser observado e trabalhado, o que evidencia certa flexibilidade da divisão trabalho.

Os entrevistados, em geral, mostraram conhecer o trabalho dos colegas e se referem objetivamente às especificidades das práticas de alguns profissionais ligadas às habilidades pessoais, reconhecendo sua legitimidade e relevância técnica, mas o fazem, sobretudo, com respeito e afeto:

(..) essa é uma equipe em que as pessoas têm muitos talentos e muitas coisas.

Então, a gente sabe que a Eliane é organizada, então a Eliane é a mulher da 
organização. A Márcia pensa com a cabeça. não só psicanalitica. mas a Márcia Innocêncio pensa. Eu gosto de pintar, de arte, de cantar então é comigo essa coisa mais especifica, de fazer bagunça. de fazer acontecer, a Maria do Carmo também, é aquela da festa. Se bem que ela é bem mais organizada na hora de botar ordem no galinheiro do que eu. administrativamente ela melhor. A Márcia Ramos é uma senhora lider, tanto que ela foi eleita pela equipe para ser diretora. O Jorge é ótimo para fazer as festas. Se quer fazer festa, normalmente se o Jorge não toma a frente, a festa não acontece. E a gente também tem que segurar o Jorge, porque senão ele só faz festa. mais do que a gente pode agüentar. Lanche também. a gente tinha brigado. porque teve uma época que ele fazia do lanche um grande festim árabe. Então, além dos saberes, tem o talento de cada um que a gente aprendeu a conhecer e a usar. Cada um sabe o que o outro tem. então a gente pega, né?" (FONOL)

Ou seja, em espaços de trabalho partilhado coexistem ações específicas, próprias de alguns campos, realizadas como trabalho especializado e que também são realizadas por profissionais de outras áreas, baseando-se na prática cotidiana:

(...) Hoje. estou atendendo uma familia junto com o Jorge, ai é atendimento...(...) eu sou a co-terapeuta. entrei morrendo de medo de fazer com ele, mas já que surgiu a oportunidade...(..) a Márcia Innocêncio que falou: 'acho que você e a Ana deviam atender a familia (de um garoto). A mãe está precisando e esse pai está se aproximando '...(...) a referência (dele) 
é o Jorge. Ela indicou. porque ela achava que ia dar certo. ela falou: 'eu acho que você vai... : eu.falei: 'eu acho que talvez não dê certo com o Jorge : Eu adoro ele. mas assim. ele é uma pessoa que conhece muito. e ele defende determinadas coisas, eu falei: 'eu vou dar uma bola fora ai'. Ele vai me comer literalmente. Mas não. a gente está se dando bem. eu acho que e o atendimento está sendo muito gratificante para nós, a gente está vendo a evolução do menino e a evolução da familia. Eu estava doida. no fundo eu queria que surgisse essa oportunidade e está legal. está sendo muito bom, eu estou aprendendo com o Jorge. Se dei bola fora, acho que depois logo corrigi. sabe essas coisas? Então está muito legal”.(ASAM)

Nos exemplos acima, acontece uma articulação da dimensão técnica da intervenção do psicólogo com o saber operante da assistente social, mediada pelas subjetividades e afinidades que buscam superar a divisão vertical do trabalho. Entretanto, ainda pode sugerir uma divisão técnica, em que os saberes são hierarquizados, revelando maior e menor autonomia profissional.

A autonomia profissional, portanto, refere-se ao grau de dominio que o profissional tem sobre a intervenção que realiza, revelando o poder decisório a ele conferido pela dimensão teórica e os diversos saberes operantes que contribuem com esta última.

As especificidades próprias de cada área também conferem autoridade técnica e autonomia a seus agentes, e estas variam na medida em que a delimitação e finalidades desses campos forem legitimadas e reconhecidas. Entre os entrevistados, 
muitos têm dificuldade de identificá-las espontaneamente, por tratarem-se de novas abordagens, campos menos tradicionais, correspondendo, portanto, a um menor grau de autonomia:

“(..) Então, assim, me interessava falar com a mãe dessas crianças. das quais eu era referência. porque sempre aparece alguma coisa que a assistente social que sabe um pouco mais de encaminhamentos e tal, mas nem isso eu tenho tanto dominio, a gente sempre discute no grupo. mas teve umas coisas que você tem um olhar differente, então você vai mais rápido... (ASAM)

Outros, ainda, negam tais possibilidades, por estarem envolvidos com outras questões teóricas:

“(...) Você sabe que agora. se você falar para mim: 'o que é um trabalho estritamente fonoaudiológico?'. para mim, é até uma questão filosọfica. tá? Porque, se você falar assim do trabalho estritamente fonoaudilógico no sentido tradicional, eu acho que nunca (fiz).(...) eu já fiz muito trabalho de desenvolvimento de linguagem e para mim o sujeito só tem linguagem se ele é sujeito. Então, para ter linguagem tem que ter um sujeito, para ter sujeito você tem que mexer na psiquê, não tem como. Então. não dá para ser estritamente... não existe isso. E foi... na minha formação como fono. foi a hora em que eu misturei. não vai ter linguagem se o "neguinho" não é sujeito." (FONOL) 
Outros, por outro lado, conseguem expressar com mais facilidade as particularidades de algumas de suas intervenções assim como sua necessidade e alcance, expressando maior autoridade técnica e autonomia, que podem aparecer em momentos mais específicos, em atendimentos individuais e, também, nas atividades em grupo:

"(..) Fazia o lanche, o almoço, sempre gostei dessas atividades. eu sou uma das pessoas que se incomoda com essa parte de alimentação, porque acontece isso que você viu agora a pouco. de um jogar... então é algo que também eu tinha até onde intervir, até hoje, dentro dessa minha especificidade. eu tenho esse olhar meio de... de olhar, de pensar assim aquelas crianças que têm essa necessidade pelo alimentar. de fazer um trabalho individual e tem dado muito resultado positivo, muito bonito, até de alguns casos, diante dessa minha vivência dentro do refeitório. você consegue fazer um trabalho individual com essas crianças e até. muitas vezes. dessa experiência a linguagem vir. Teve um caso muito interessante que aconteceu isso, então desde aquela época, eu sempre achei um espaço muito importante." (FONOM)

No caso da trigem, tem sido realizada em sistema de parceria e rodizio entre profissionais médicos e não médicos, mas há referência à necessidade de que sejam feitas sob retaguarda das médicas, pois a avaliação psiquiátrica "fecha o diagnóstico". Além disso, como na atualidade se medica mais e ainda é restrito o conhecimento acerca dos novos medicamentos e do avanço dos psicofármacos, faz-se necessário 
uma atenção maior na avaliação medicamentosa, que é especifica do profissional médico:

“(..) A triagem na época funcionava assim: a assistente social dava uma primeira entrevista, uma selecionada, dai a gente avaliava, normalmente, eu fazia com... quem era da triagem? Deixa eu tentar lembrar: era eu. o Marcelo. o Quinta, quem mais? Acho que a Mira. a Tereza fazia um pouco. eu estou esquecendo de alguém....(...) A Mira e o Marcelo (eram psicólogos). O Quinta era psiquiatra, a Tereza, TO, mas a Tereza não atuava muito como TO não. ela era psicanalista...(..) a gente meio que tirou assim: passa com psiquiatra e com o serviço social. O serviço social até faz uma primeira avaliação. vê se é isso mesmo que a pessoa quer. se é elegivel e ai a avaliação psiquiátrica para fechar diagnóstico. mas isso a gente tinha tirado mesmo na época, então não fazia junto com o Quinta. porque não fazia muito sentido dois profissionais da mesma área, acho que já tinha essa idéia de poder misturar os profissionais." (PSIQMC)

Esta atividade, portanto, é centrada na clinica psiquiátrica, mas os profissionais dessa área recorrem aos psicólogos e fonoaudiólogas para um diagnóstico diferencial, sobretudo nos casos de transtornos globais do desenvolvimento.

Os profissionais não médicos que realizam ou realizaram triagens também reconhecem a importância da avaliação criteriosa e alguns apontam as possibilidades 
do estabelecimento dos vínculos que este momento, que pode ser o facilitador das relações mãe/crianças/HDI e o principio do entendimento da dinâmica familiar:

(...) um outro mais tradicional também. o Marcelo, e a gente fazia muito trabalho de diagnóstico, por causa do raciocinio clínico. aprendi muito com ele: ele era psicólogo, mais analista, mas ele tinha um raciocinio mais clinico. então a gente combinava bem na hora de fazer diagnóstico..." (FONOL)

“(..) a triagem sempre ia em dois. Então era... vamos supor que eu fizesse com psicólogo, então eu tinha visão mais... eu consigo ver a psicose pelo jeito da criança falar. como ela estrutura a linguagem. É interessante. $\dot{E}$ diferente de um psicólogo que vai ver algumas coisas, eu fico ligada no cognitivo, por causa da minha formação lá no mestrado em Piaget, dentro de estigma eu estudei pra caramba Piaget, porque eu ia fazer outra coisa. Então, eu ficava muito ligada no desenvolvimento cognitivo. como é que estava. então o jeito de brincar, mais pelo cognitivo. Ai, eu fui aprendendo também a interpretar. por causa do outro trabalhando junto. né? Não só do que eu tinha lido, mas do que tinha sido na prática. Então foi muito assim da gente se ensinar. né? Então. a triagem era assim, era dos dois. Daí os dois juntos. a gente discutia e chegava num... não era nem um diagnóstico psiquiátrico, não. "Essa criança é para o HD? O que era para o HD? É um caso grave, a tal ponto que ninguém mais agüenta. então a gente tem que ficar com ele." (FONOL) 
Assim, as fonoaudiólogas sempre dão a retaguarda para todos os profissionais, para que se desenvolva uma percepção dos problemas de linguagem ou até mesmo de eventuais distúrbios articulatórios que possam ser captados, por exemplo, na hora das refeições, na hora da escovação dos dentes ou em outros espaços que aparecerem, mas também existe para algumas crianças um trabalho mais direto, mais individualizado, mais especifico de fonoterapia, que vai trabalhar aspectos da própria aquisição da linguagem ou da própria construção do sujeito:

"eu tenho ficado com as crianças que têm apresentado dificuldades de estar no refeitório, mas com objetivo, com a visão de que assim, seria esse trabalho no dual. mas que vai possibilitar assim que ela esteja mais... você vai percebendo que ela já pode. eu até acompanho essa criança depois no refeitório, fico um tempo no refeitório com essa criança para fazer essa passagem e ai já vou vendo a necessidade talvez de uma outra, porque os casos dos autistas, principalmente, eles têm uma seletividade no sabor. nessas coisas, que você precisa... muitas vezes o olhar o alimento do outro gera ânsia. então entra um pouco da especificidade, mas às vezes. porque o primeiro momento da mãe com a criança é o alimentar. e muitas vezes até a linguagem surge desse trabalho que foi feito na alimentação. especifico da alimentação, aconteceu um caso que foi através desse momento que começou aparecer, está até descrito, é muito interessante... (FONOM) 
As enfermeiras também entram nas atividades com um "olhar" mais voltado para as questões da saúde fisica, evidenciando sinais de gripe, febre, outras doenças comuns em crianças, ou mesmo outras deficiências, e os efeitos colaterais que por ventura alguma medicação pode causar, sendo que é preciso uma atenção e o entendimento das reações (adversa ou não) que podem desencadear:

“(...) Quer dizer, existe uma forma de olhar diferente, e a gente começou a ver que tinham umas coisas especificas, que eu falei: "não adianta. só a gente vai olhar". Então, na época, quando os auxiliares chegaram $e$, principalmente quando chegou a segunda enfermeira, isso um ano depois, a Neusa que está aqui até hoje. Então dai a gente falou: "não, tem algumas coisas especificas". mas a criança entra aqui para trabalhar a questão emocional, a questão das relações. da psicose, do autismo, então assim: "mas tem algumas questões que são da parte fisica, de saúde fisica da criança". Então a gente começou a fazer um questionário na época, para conhecer melhor essa criança, são crianças que ficam aqui três vezes por semana, três horas, quatro horas e a que gente não sabe muita coisa dela. A gente não sabe se ela tem alergia por algum tipo de alimento, se ela, por exemplo, tem convulsão, porque nem sempre isso é perguntado. porque a criança pode convulsionar e gente tem que saber como lidar com isso..." (ENFE) 
Em uma abordagem mais voltada para as atividades de vida diária, a terapeuta ocupacional está mais preparada para a intervenção e retaguarda necessárias, a partir das quais é possivel trabalhar habilidades e percepções:

“(..) eu atendi duas crianças individualmente, que não estão mais em atendimento individual, porque o objetivo era justamente. com atividades mais concretas. tentar um vinculo para depois estar com elas no grupo.(...) Esse atendimento individual, eu usava objetivos de TO mesmo assim. trabalhar mais AVD's, esquema corporal, imagem corporal. via o brincar para conseguir algum olhar dessas duas crianças. Uma, que não conseguia estar no grupo e outra. uma criança muito dificil de se desgrudar de um jornal. na época era só o jornal o objeto que ele gostava e... então eu fiz esse atendimento mais com o objetivo de introduzir essas crianças no grupo, então foi mais pontual. E ai o que eu usava? Eram as coisas que eu sei fazer de TO. Então era brincar de... crianças semi-dependentes em AVD's, então eu acabava usando esse momento para fazer algum tipo de treino mesmo, bem especifico. Funcionou, acho que mais com uma criança do que com a outra. E com a outra deu mais certo as brincadeiras de esquema corporal. acho que valeu mais." (TOMI)

O atendimento ao núcleo familiar é, em geral, conduzido por um psicólogo ou um psicólogo e um outro colega que tenha uma formação psicanalítica, seja terapeuta ocupacional, seja fonoaudiólogo, seja o psiquiatra. No caso destas três últimas categorias, todos têm essa formação e realizam as terapias vinculares: 
“(..) Eu atendo duas familias, também sozinha. (...)As crianças das quais eu sou referência, eu atendo as familias, mas não é todo mundo que è referência que gosta. que atende. Não é uma conduta do HD. Tem criança que entrou na terça, a mãe já entrou no grupo de familia na outra terça. meio automaticamente. Agora. a gente está tomando um pouco mais de cuidado. Eu acho que ter entrado gente nova como eu e a Ana, que gostamos bastante de trabalhar com familias traz a equipe aquela vontade de discutir. " (TOMI)

Em relação aos grupos de familia, quase todos o fazem, pois as mães recebem periodicamente apoio e são ouvidas, também podem ser realizados em parceria:

"(..) faço grupo de familiares na terça-feira. (...) Sozinho. Eu e os familiares. Eu sozinho, é o único grupo de familiares que é feito sozinho, mas para mim tudo bem.... (....) não tinha possibilidade naquele momento. que eu comecei a fazer o grupo, em co-terapia com alguém. pelo número de profissionais, que estava acontecendo outras atividades, eu acabei... um grupo muito dificil que eu acabei me dando bem com ele e fiquei. Foi um desafio, eu também gosto de desafios. " (PSIJ)

A flexibilidade da divisão do trabalho referida ou, ainda, a divisão horizontal, caracterizada pelo compartilhamento das tarefas e pela freqüente articulação dos saberes técnico e operante ocorre em função da própria natureza do objeto de intervenção e reflete os preceitos da Reforma Psiquiátrica, cujo grande objetivo é a reabilitação psicossocial e a promoção da saúde mental. Desta forma, é possível 
perceber o deslocamento, na dimensão técnica, da hegemonia médica para a psicológica, em que predominam as abordagens psicanaliticas, revelando, ao mesmo tempo, a necessidade intrínseca de atualização do próprio modelo médico para a construção desse novo projeto terapêutico destinado a pessoas com transtornos mentais, cujas necessidades são necessariamente multifacetadas (GOLDBERG 1992; 1998).

O reconhecimento da pluralidade do objeto da saúde mental conduziu às mudanças de paradigmas e estas se expressam nas situações de trabalho coletivo mencionadas, nas quais algumas especificidades se diluem e outras são apropriadas por agentes de diferentes áreas. Entretanto, não há uma superação radical das especificidades, pois se houvesse, o caráter interdisciplinar reivindicado e mencionado nos depoimentos estaria ameaçado, assim como a própria percepção de que são uma equipe.

Tal interdisciplinariedade, expressa em princípio pela multiprofissionalidade dos agentes, pode ser apreendida nos discursos pela referência que fazem a determinados trabalhos especializados, caracterizados por ações peculiares e próprias a cada profissional, que por sua vez, revelam valorações e hierarquias desiguais, socialmente determinadas, no interior do próprio trabalho coletivo que não são claramente evidenciadas pelos entrevistados, mas que aparecem sutilmente quando negam sua formação ou se remetem às especificidades de outras áreas. Ao mesmo tempo, a própria despreocupação ou dificuldade em demarcar as fronteiras dos diferentes campos teóricos pode sugerir, ao invés de uma interdisciplinariedade stricto senso, uma multiprofissionalidade mediada pela hegemonia psicanalítica. 
Por outro lado, as situações de conflito e divergências entre os profissionais foram mais identificadas nos fóruns de discussão dos casos, ou seja, nas reuniões de periodo e na reunião geral, e se referem às próprias intervenções. Nesse momento, uma vez que os laços pessoais estão devidamente resguardados, se expressam as especificidades e particularidades das formações pelo debate técnico e teórico acerca das concepções e da condução do trabalho. Consistem, portanto, em espaços privilegiados de negociação das diferenças, do exercicio da interdisciplinariedade:

“(..) algumas reuniões são operativas, satisfatórias e realizadoras. e tem reuniōes não. O perigo da reunião quando ela não é satisfatória é as pessoas começarem a ficar resistentes a irem. a querer participar das outras reuniões. elas são obrigatórias. As pessoas acabam eventualmente atrasando. levantando e saindo não sei quantas vezes e esse ano parece que começou melhor. porque as reuniões têm sido mais efetivas, e ai quando as pessoas vêem resolutividade na reunião, que não ficou só nas discussão. que tirou encaminhamentos, condutas, isso traz uma satisfação para todo mundo e dá vontade de continuar participando da reunião. (PSIJ)

“(..) ultimamente tem sido mais discussão dos casos, está ficando mais focado na criança do que na atividade em si, então às vezes, a gente falha um pouco nesse sentido. mas quando acontece é rico, quando a gente pára para discutir o espaço: "oficina cultural. vamos falar sobre isso?". acaba surtindo então um efeito bom, positivo. tem mudança, é uma equipe que consegue agüentar critica, modificar. nesse sentido a gente percebe isso. tem esse movimento(...)” (FONOM) 
Os conflitos ou dificuldades do trabalho coletivo no HDI podem ser percebidos em alguns espaços partilhados, pelas diferenças de concepções acerca das oficinas:

(...) é legal que a gente começa a contar as histórias de verdade para depois entrar no faz-de-conta, boa parte das crianças já entende o que é faz-deconta. Então, isso para mim é um trabalho... porque eu estou trabalhando com crianças que têm limitações, que têm quadro psicótico e se elas puderem separar o que é real do que é faz-de-conta. eu estou conseguindo algo... que é um enfoque completamente diferente do Jorge. Ele que propôs, ele tem a tese de mestrado, então assim, ele fica meio bravo. ai eu falo: "Jorge, não vou fazer oficina de história, nem com o seu objetivo. nem do teu jeito". (PSIQMC)

Outras divisões de tarefas são aquelas que correspondem aos outros espaços estruturais do serviço, e ai tem-se uma divisão operacional, de quem é responsável pela cozinha, pelo expediente, pela faxina, ainda que todos esses funcionários tenham que estar se remetendo à direção clínica e administrativa freqüentemente, para receberem as coordenadas de como as coisas devem andar e mesmo para situar as chefias de como estão andando.

O psicólogo e a psiquiatra são, portanto, os profissionais que referem com mais objetividade a especificidade de seus campos e de algumas de suas ações. $O$ primeiro, em função da própria mudança de modelo, se encontra numa posição 
privilegiada na atual estrutura, ou seja, em uma abordagem psicodinâmica o saber psicológico é dominante e todas as atividades, individuais ou em grupo, passam necessariamente por esse referencial. A segunda, a partir da flexibilidade de sua postura pessoal dentro do conjunto do trabalho, em que compõe em atividades partilhadas, encorajada também por sua formação psicanalítica, consegue resguardar a intervenção médica em atividades ambulatoriais e nas triagens e diagnósticos.

Quanto ao atendimento familiar, existem três modalidades de intervenção: as terapias vinculares e os grupos de familiares centrados na figura materna, cujo caráter é psicoterapêutico e um trabalho de apoio e orientação, realizados por diversos profissionais, como a assistente social e a enfermeira.

Sobre a terapia ocupacional. Márcia Innocêncio tem uma filiação mais analitica, assim como a outra TO que integrou a equipe; Já Maria do Carmo, a psiquiatra, diz que é necessário "um trabalho de to to". As fonoaudiólogas, por sua vez, se relacionam de formas diferentes, mas complementares dentro deste campo: Liege buscou um caminho mais psicoterapêutico ou analitico enquanto que Marici preza a especificidade da intervenção nos moldes mais tradicionais.

As enfermeiras têm uma formação de saúde pública, mas não se identificam com a enfermagem tradicional, nem com a abordagem gerencial para a qual se encaminhou a enfermagem hospitalar. Buscam no trabalho um outro campo ou formas diferenciadas de atuação. Falam do movimento de desconstrução necessário para que seja possivel a re-construção do "olhar".

Os próprios objetivos e dinâmicas das atividades do HDI requerem que os profissionais articulem diversos saberes técnicos e que acrescentem outros enfoques 
além daqueles peculiares à sua área profissional. Neste sentido, as oficinas terapêuticas oferecem essa possibilidade: é utilizada para os profissionais observarem e perceberem as crianças e seu envolvimento nas atividades e são, ao mesmo tempo, a própria intervenção.

Ao falarem da complementariedade entre os diversos trabalhos, referem de outra forma "as maneiras diferenciadas de olhar", ou seja, dos diversos aspectos que podem ser notados com base no conhecimento especifico de cada um, decorrendo dai intervenções direcionadas, facilitadas pelas situações em que as crianças estão nos grupos. Não se utilizam de estereótipos ao falarem dos diversos trabalhos, das diversas áreas. Mas todos deixam explicitam a nova hegemonia, desta vez compartilhada, que orienta suas intervenções: os saberes da psicologia e psicanálise. Não demarcam fronteiras. Talvez só a médica tenha necessidade de fazer isso, segundo suas próprias palavras.

Contudo, as especificidades de cada profissão ou área de formação e conhecimento acabam 'se perdendo', pois há muita partilhação das ações ou dos diversos trabalhos especializados, que nos depoimentos, de forma geral, se traduzem como "um olhar" diferenciado, reconstruído e mutiplicado. E, de acordo com o Livro dos Conselhos, se podes olhar, vê. Se podes ver, repara... 


\title{
5 \\ Considerações finais
}

\author{
Quando lerem seus papéis \\ Pesquisando. dispostos ao assombro \\ Procurem o Velho e o Novo. pois nosso tempo \\ E o tempo de nossos filhos \\ $\dot{E}$ o tempo das lutas do Novo com o Velho. \\ $A$ astúcia da velha trabalhadora \\ Que toma ao professor seu saber \\ Como um fardo pesado demais. é nova. \\ $E$ deve ser mostrada como Novo. E velho \\ É o medo dos trabalhadores. durante a guerra \\ De aceitar os panfletos que têm o saber; deve \\ Ser mostrado como Velho. Mas \\ Como diz o povo: na mudança de lua \\ A lua nova segura a lua velha \\ Uma noite inteira nos braços. \\ $A$ hesitação dos receosos \\ Anuncia o novo tempo. Sempre \\ Determinem o Já e o Ainda! \\ As lutas de classes \\ As lutas entre Velho e Novo \\ Ocorrem também dentro de cada um \\ A disposição de ensinar do professor: \\ $O$ irmão não vê. um estranho vê. \\ Examinem todas as ações e emoções de seus personagens \\ $\mathrm{Na}$ busca de Velho e Novo! \\ As esperanças da mercadora Coragem \\ São fatais para seus filhos: mas o desespero \\ Dos mudos com a guerra \\ Pertence ao Novo. Seus movimentos desamparados \\ Ao arrastar o tambor salvador para o telhado \\ A grande ajuda. devem enchê-los \\ De orgulho: a energia \\ Da mercadora que não aprende. de compaixão \\ Lendo seus papéis \\ Pesquisando, dispostos ao assombro \\ Alegrem-se com o Novo. envergonhem-se do Velho!
}

Bertolt Brecht, Poemas 1913-1956 
A finalidade do trabalho em saúde mental não deve e não pode se limitar ao sintoma, e neste aspecto os entrevistados apontam para a necessidade de todos entenderem ou reconhecerem dada sintomatologia para amenizá-la ou mesmo evitá-la. Resgatar os sujeitos (crianças e familiares) e contribuir com a construção de sentidos, observar habilidades e afinidades a partir do movimento de exteriorização dessa problemática via a inclusão social devem ser, ainda, as preocupações de quem atua na área de saude mental.

Ou seja, a abordagem multifacetada, psicodinâmica adotada pelos serviços substitutivos favorece a complementariedade e interdependência dos trabalhos especializados, demarcando pontos de intersecção das diferentes ações, nos quais se revela o instrumental de cada área profissional.

Há uma tensão entre as especificidades profissionais e a flexibilidade da divisão do trabalho, pois esta última acaba contribuindo para uma descaracterização de áreas como o serviço social e até da enfermagem.

O caráter interdisciplinar do trabalho em saúde mental se revela pela busca de formação dos entrevistados, em geral, direcionada para a psicanálise e à psicologia. Novos embasamentos, novos caminhos, novos direcionamentos de suas ações acabam, portanto, fundindo os demais saberes à psicanálise e à psicologia, que na prática cotidiana é mais dificil destacá-los, tais como as intervenções tradicionais do serviço social e da fonoaudiologia. A especificidade é convocada por necessidades e demandas de determinados pacientes, ao precisarem de alguma intervenção mais direcionada, aparecendo, portanto, nas situações concretas de atendimento, como dito anteriormente. 
Duas possibilidades de articulação dos distintos saberes técnicos podem ser identificadas: uma quando o agente com sua formação multiprofissional lança mão de diferentes recursos e instrumentos técnicos em uma mesma intervenção; outra, quando diferentes agentes, de diferentes áreas compõem em suas intervenções.

A dimensão da autonomia profissional e a capacidade de julgamento e decisão de cada área profissional são remetidas novamente à dimensão intelectual do trabalho, ou seja, ao saber técnico que the confere legitimidade cientifica e social, que no caso corresponde à 'boa' formação e experiência profissional de cada um.

A relativização da autonomia profissional, sobretudo a médica, reitera a mudança ou flexibilização do modelo médico psiquiátrico e indica que todos os profissionais envolvidos se sentem responsáveis pelo projeto assistencial. pois como foi dito, percebem que integram um projeto comum Neste sentido, sentem-se responsáveis pela sua ação e co-responsáveis pelas demais.

Ao falarem do trabalho que realizam no HDI, em geral, iniciam se referindo às oficinas das quais participam ou participaram, ou seja, mencionam as atividades partilhadas e estas correspondem à ações meio, a partir das quais é possivel certa organização e reconhecimento das questões trazidas pelas crianças e suas familias e também à ações fim, em que são trabalhados os medos, dificuldades de simbolizações, percepções e de socialização. Neste sentido, parece ser mais fácil falar sobre os aspectos que aproximam ou integram as diferentes ações do que daquilo que as diferencia, que seria a própria expressão da multiprofissionalidade, dada a participação de todos os profissionais em todos os momentos do processo, desde a 
concepção e construção da proposta de trabalho até o próprio processo de trabalho ou prestação da assistência.

Ou seja, a percepção acerca do trabalho em saúde mental passa, necessariamente, pela noção de trabalho em equipe que desenvolveram e compartilham objetivamente, mas que também tem ressonâncias do campo teórico, pois:

“(.. ) chama a atenção o volume de produção teórica sobre equipe no campo da saúde mental. (...) a noção e utilização de equipes psiquiátricas e de saúde mental aparece na literatura desde o inicio da década de 30 (...). Também repercutem nesta produção intelectual acerca da equipe em saúde mental. os estudos de dinâmica de grupo que se iniciam, na área da psicologia. com os estudos dos pequenos grupos de trabalho" (PEDUZZI Op. Cit.; p.5).

Os entrevistados referem que é impossível trabalhar com saúde mental senão for em equipe e esta percepção implica que os profissionais cuidem das relações interpessoais e estabeleçam conexões também neste âmbito, pois estas perpassam o cotidiano do trabalho e se refletem diretamente no trato com os pacientes. Assim, as ações técnicas direcionadas aos usuários ganham um sentido de integralidade e respaldo ainda maiores. Em geral, ao se referirem ao trabalho dos demais profissionais, de suas qualidades técnicas, os entrevistados o fazem nominalmente e suas habilidades pessoais sempre são destacadas. 
As diferenças técnicas entre os trabalhos especializados são percebidas por todos os profissionais e valorizadas como meio de troca e de aprendizado e aprimoramento do próprio trabalho. As diferentes formas de significarem as oficinas terapêuticas são um bom exemplo dessa particularidade de percepção, que talvez alguns nem se dêem conta.

No que tange às relações hierárquicas entre os profissionais, estas também aparecerem, sobretudo demarcando os territórios da psicologia e psicanálise, psiquiatria e demais campos, que buscam integrar-se nesses paradigmas. Nesse aspecto, mesmo considerando o caráter multidimensional do objeto de intervenção, em termos do conhecimento, acontece um deslocamento da hegemonia médica para a psicológica, recolocando novamente a necessidade de re-articulação dos demais saberes, tanto na abordagem teórica como na concreta. Encontram-se, desta forma, situações objetivas do trabalho coletivo em que se expressam certas desigualdades entre os saberes, ações e quem as conduz.

As condições e regras para uma boa convivência com as diferenças são resultado das negociações de um grupo de profissionais que se conhecem bem e se respeitam e a esfera dos conflitos e os mecanismos para lidarem com eles também foram construidas pelos profissionais ao longo desse tempo compartilhado.

$\dot{E}$ possivel resgatar dos depoimentos a noção de trabalho em equipe que foi exercitada desde o momento em que começaram a pensar sobre a grade de atividades do HDI e nesta gênese enraizaram-se as atuais características da equipe: integrada, afinada nos objetivos e nas linguagens comuns, sintonizada quanto às especificidades; antenada ante os perigos de se tornarem fechados e "cronificados". 
A prática de discussão em reuniões de periodo ou de equipe geral, como espaços que possibilitam a criação de fluxos comuns e de reflexão e negociação de diferentes pontos de vistas, proporciona a superação de problemas e também são espaços em que aparecem as subjetividades. Nelas acontecem os planejamentos e a organização e avaliação das atividades oferecidas pelo serviço como um todo.

A participação de todos os profissionais em todos os momentos do processo de trabalho, da concepção e execução à avaliação, permite-lhes, portanto, a visão e percepção de seu trabalho como sendo um trabalho em equipe. Dessa visão de conjunto emergem as possibilidades de flexibilização da divisão do trabalho, dada a implementação de diretrizes comuns, partilhadas. Os consensos quanto à organização e ao projeto assistencial são o resultado dessa elaboração, em que cada atividade é considerada e re-pensada na intersecção desses momentos, de concepção e da prática cotidiana.

Ou seja, a participação dos profissionais em todos os momentos do processo de trabalho possibilita, para cada um deles, a visão de conjunto da assistência que representa e do plano terapêutico para cada criança em particular, expressando-se, ao mesmo tempo, as intervenções especificas de cada área profissional, favorecendo o reconhecimento dos trabalhos especializados.

A assistente social, por exemplo, refere o trabalho em equipe como a possibilidade de aprendizado com os outros profissionais. A médica refere sua percepção acerca da construção de linguagens comuns entre os agentes, tanto no que diz respeito às diferenças das áreas profissionais, quanto às diversas linhas de um mesmo saber, tal como a psicanálise. Segundo ela, os profissionais que participam das 
oficinas podem ter pontos de vistas diferentes quanto à forma de conduzi-las e estas diferenças sofrem influência direta da prática cotidiana da intervenção. Os pontos comuns, por sua vez, também podem ser revelados pelo trabalho cotidiano, o que também facilita os consensos e traduz a interdisciplinaridade na abordagem do objeto de intervenção ao mesmo tempo em que os entrevistados destacam a dimensão da cooperação no trabalho, tanto no plano técnico como no instrumental.

Assim, ao falarem do trabalho em equipe, os profissionais, em geral, apontam para a necessidade de reconhecimento mútuo acerca da contribuição especifica de cada profissional, referindo-se, também à necessidade de cada particularidade ser dirigida para um resultado comum.

Tal como os depoimentos da fonoaudióloga terapeuta ocupacional e enfermeira acerca de suas atribuições específicas nas atividades de alimentação de que participam: é possivel pontuar as particularidades dos trabalhos desenvolvidos por elas, quando estão juntas ou não, caracterizando essa atividade como tarefa comum a todos que dela participam, mas lançando mão de saberes técnicos diferenciados. Embora a noção de trabalho em equipe dos entrevistados não se resuma às tarefas comuns, colocadas para os profissionais que delas participam, abarcando também todos os aspectos processuais de construção do projeto de intervenção, parece haver, em alguns casos, uma "auto-concepção de grupo" como "grupo operativo" no sentido "pichoneano". Desta forma, alguns esforços, operantes sobretudo, se concentram na tarefa.

Os entrevistados assinalam, ainda, a necessidade de manutenção das especificidades técnicas das diversas áreas profissionais e da flexibilidade da divisão 
do trabalho, de modo que os agentes possam realizar as intervenções com base na experiència cotidiana e coletiva de trabalho. Com efeito, os depoimentos não descartam a possibilidade desta flexibilidade na divisão do trabalho gerar conflitos e misturas, as quais sejam dificeis de superar, mas que são superadas pela capacidade de diálogo desenvolvida, à exemplo do que outros profissionais recomendam:

"que o conhecimento e a explicitação das diferenças técnicas e das desigualdades valorativas dos trabalhos, através da comunicação. permitem articular as múltiplas ações, comuns e específicas.(...) Assim, os entrevistados mostram que suas concepções de trabalho em equipe supõem relações reciprocas entre a intervenção técnica, ou seja, as atividades do trabalho e a interação dos agentes. Ou seja, no trabalho em equipe prevalece o técnico. visto que se trata de uma ação racional dirigida a um fim. fim este representado pela atenção às necessidades de saúde mental dos usuários. Mas este técnico configura um projeto assistencial comum à equipe e construido através de consensos derivados da interação. Portanto, o trabalho em equipe não pode prescindir da comunicação livre de coação entre os múltiplos agentes. E a interação permite o consenso em torno de linguagens. propostas e objetivos comuns que articulam as ações $e$ integram os saberes operacionalizados no cotidiano do trabalho em equipe" (PEDUZZI Op. Cit). 
No que se refere à supervisão, tanto a clinica como a institucional, os entrevistados apontam sua importância para que sejam feitas as mediações necessárias entre os aspectos técnicos e operantes e, também, entre o conjunto dos trabalhos e os trabalhos particulares e corrijam os vicios e evitem as cronificações, sobretudo em uma equipe que está junta há tempos e citam, na atualidade, a recorrência a supervisões internas, conduzidas por profissionais do próprio serviço, aqueles que têm uma formação adequada e também mais experiência profissional e gerencial, como é o caso da diretora da unidade. 


\section{6 \\ Referências}

Quem me dera

fossem agora escritas as minhas palavras!

Quem me dera fossem gravadas em um livro!

Jó. Livros Sapienciais 
Abreu ARP, organizador. Produção flexível e novas institucionalidades na América Latina. Rio de Janeiro: Editora UFRJ; 2000.

Almeida MCP. Estudo do saber de enfermagem e sua dimensão prática. Rio de Janeiro; 1984. [Tese de doutorado - ENSP]

Amaral MA Atenção à saúde mental na rede básica: estudo sobre a eficácia do modelo assistencial. Rev Saúde Pública 1997; 31: 288-95.

Amarante $P$, organizador. Loucos pela vida: a trajetória da reforma psiquiátrica no Brasil. Rio de Janeiro: Panorama; 1995.

Antonacci MAM A vitória da razão (?): o IDORT e a sociedade paulista. São Paulo: Marco Zero/CNPq; 1993.

Antunes EH. Saúde mental em atenção primária no estado de São Paulo. São Paulo; 1998. [Dissertação de Mestrado - Faculdade de Medicina da USP].

Antunes LR. Crise e perspectivas da sociedade salarial: algumas observações sobre as novas formas da sociabilidade, da solidariedade e da cidadania. Rev Ciênc Hum Soc da UNISA 2000;1(2): 5-14.

Antunes LR Reestruturação produtiva e sistema bancário: movimento sindical bancário brasileiro nos anos 90. Campinas; 2001. [Tese de doutorado - Instituto de Economia da UNICAMP].

Antunes MAM. A psicologia no Brasil: leitura histórica sobre sua constituição. São Paulo: Unimarco/Educ; 2001. 
Arcaro NT. Caracterização de aspectos da clientela e sistema de atendimento de um ambulatório de saúde mental. São Paulo; 1989. [Tese de Doutorado Faculdade de Medicina da USP].

Arcaro NT, Mejias NP. Evolução da assistência psicológica e em saúde mental: do individual para o comunitário. Psicol Teor Pesq 1990; 6: 251-67.

Arouca ASS. O dilema preventivista. Campinas; 1975. [Tese de doutorado Faculdade de Ciências Médicas da UNICAMP].

Baltiere DA, Andrade AG. Transtormos psiquiátricos comuns no Serviço de Emergência Psiquiátrica: uma experiência do Centro Hospitalar de Santo André. Rev Bras Med 2002; 59: 585-9.

Bardin L. Análise de conteúdo. Lisboa: Edições 70; 1997.

Bazaglia F. A instituição negada. Rio de Janeiro: Graal; 1985.

Berger M, Montanari PM, Silva CG. Quando o espelho não reflete: os alunos portadores de deficiências na USP. São Paulo: CECAE/ USP; 1992. [Relatório de Pesquisa].

Berberian AP. A normalização da linguagem: práticas fonoaudiológicas 19201940. São Paulo; 1993. [Dissertação de Mestrado - PUCSP].

Birman J, Costa JF. Organização de instituições para uma psiquiatria comunitária. In: Relatórios e Resumos do $2^{\circ}$ Congresso Brasileiro de Psicopatologia InfantoJuvenil; 1976, abr 14-18; Rio de Janeiro: APPIH; 1976.

Birman J. A psiquiatria como discurso da moralidade. Rio de Janeiro: Graal; 1978. 
Bosi E. Memória e sociedade: lembranças de velhos. São Paulo: T. A. Queiroz; 1983.

Braga JCS. A questão da saúde no Brasil. Campinas; 1978. [Dissertação de Mestrado - Instituto de Economia da UNICAMP].

Busnello EAD. A integração da saúde mental num sistema de saúde comunitária. Porto Alegre: Editora da UFRGS; 1976.

Cambraia M. As práticas e os processos de trabalho nos ambulatórios de saúde mental. São Paulo; 1999. [Dissertação de Mestrado - Faculdade de Saúde Pública da USP].

Campiglia MAD. A ambigüidade de uma profissão: o sofrimento psíquico na enfermagem. São Paulo; 1998. [Dissertação de Mestrado - UNIFESP/EPM].

Carapinheiro G. Saberes e poderes no hospital: uma sociologia dos serviços hospitalares. Porto: Edições Afrontamento; 1993.

Chanlet JF. O individuo nas organizações: dimensões esquecidas. São Paulo: Atlas; 1992.

Ciampone MHT, Peduzzi M. Trabalho em equipe e trabalho em grupo no programa de saúde da familia. R Bras Enferm 2000; 53(n. especial):143-7.

Cohn A. ONG, movimentos sociais e privatização do atendimento médico: experiências em São Paulo. In: Reilly C, organizador. Novas políticas urbanas: ong e governos municipais na democratização latino-americana. Arlington: Fundação Interamericana; 1994. p. 95-109. 
Cohn A. O plano de assistência à saúde do município de São Paulo: uma modalidade alternativa de gestão? Rev Adm 1998; 33: 44-50.

Comin A, organizador. $O$ mundo do trabalho: crise e mudança no final do século. São Paulo: Scritt; 1994.

Conselho Federal de Fisioterapia e Terapia Ocupacional. Em lugar da patologia, foco na inclusão social. O COFFITO 2002; 17: 12-5.

Costa NR Lutas urbanas e controle sanitário: origens das políticas de saúde no Brasil. Petrópolis/RJ: Vozes/ABRASCO; 1985.

Cunha MCP. $O$ espelho do mundo: Juquery, a história de um asilo. $2^{a}$. ed. Rio de Janeiro: Paz e Terra; 1986.

Da Matta R. O oficio do etnólogo ou como ter Anthropological Blues. In: Nunes E, organizador. A aventura sociológica: objetividade, paixão, improviso e método na pesquisa social. Rio de Janeiro: Zahar; 1978. p.23-35.

Da Matta $R$. Carnavais, malandros e heróis: para uma sociologia do dilema brasileiro. Rio de Janeiro: Zahar; 1979.

Dallari SG. A saúde do brasileiro. São Paulo: Moderna; 1987. [Projeto Passo à Frente. Coleção Polêmica, 7].

Dalmolin BM. Reforma psiquiátrica: um processo em construção na prática dos enfermeiros do Rio Grande do Sul. São Paulo;1998. [Dissertação de Mestrado Faculdade de Saúde Pública da USP]. 
Del-Bem CM, organizador. Políticas de saúde mental e mudanças na demanda de serviços de emergência. Rev Saúde Pública 1999; 33: 470-6.

Dias ESC. Construção da rede alternativa em saúde mental: um olhar sobre o hospital. In: Anais do $3^{\circ}$ Simpósio de Iniciação Científica. Ribeirão Preto: USP; 1995; v.1; p. 324.

Donnangelo MCF. Medicina e sociedade. São Paulo: Pioneira; 1975.

Donnangelo MCF, Pereira L. Saúde e sociedade. São Paulo: Duas Cidades; 1979.

Elias LA. O analista em sua formação. Psychê Rev Psicanál 1999; 3(3): 73-80.

Espinosa AMF. Psiquiatria. Rio de Janeiro: McGraw-Hill Interamericana do Brasil; 1998. (Guias Práticos de Enfermagem).

Fernandes MIA, organizador. Fim de século: ainda manicômios? São Paulo: IPUSP; 1999.

Figueiredo GR A evolução do hospício no Brasil. São Paulo; 1996. [Tese de Doutorado - UNIFESP/EPM].

Figueiredo Neto LE. O início da prática fonoaudiológica na cidade de São Paulo: seus determinantes históricos e sociais. São Paulo; 1988. [Dissertação de Mestrado - PUCSP].

Foucault M. Doença mental e psicologia. Rio de Janeiro: Tempo Brasileiro; 1975.

Foucault M. Microfísica do poder. 10. ed. Rio de Janeiro: Graal; 1992. 
Foucault M. Arqueologia do saber. Petrópolis: Vozes; 1999.

Friedson E. La profesión medica. Barcelona: Península; 1978.

Fundação IBGE. Censo Demográfico: resultados preliminares - Brasil. Rio de Janeiro; 2000. v.1, n.4. ( $10^{\circ}$ Recenseamento Geral do Brasil)

Fundação SEADE. Anuário estatístico do Estado de São Paulo: 2002. São Paulo; 2003.

Giordano JR S. A perspectiva da higiene e a doença mental: contribuição à história das políticas de saúde mental no Estado de São Paulo. São Paulo; 1989. [Dissertação de Mestrado - Faculdade de Medicina da USP].

Goldberg JI. Doença mental e as instituições: a perspectiva de novas práticas. São Paulo; 1992. [Dissertação de Mestrado - Faculdade de Medicina da USP].

Goldberg JI. Cotidiano e instituição: revendo o tratamento de pessoas com transtorno mental em instituições públicas. São Paulo; 1998. [Tese de Doutorado - Faculdade de Medicina da USP].

Gomes FZ. Mulheres e crianças primeiro! $O$ caráter da intervenção do Estado no grupo materno-infantil da colônia ao milagre brasileiro. São Paulo; 1988. [Dissertação de Mestrado - Faculdade de Saúde Pública da USP].

Heller A. O cotidiano e a história São Paulo: Paz e Terra; 1970.

Iamamoto MV. O serviço social na contemporaneidade: trabalho e formação profissional. São Paulo: Cortez; 1998. 
Japiassủ, H. A revolução científica moderna. Rio de Janeiro: Imago; 1985.

Kidder L, organizador. Métodos de pesquisa nas relações sociais. São Paulo: EPU; 1987.

Koupernik C, organizador. Antipsiquiatria: senso ou contra-senso? Rio de Janeiro: Zahar; 1976.

Labate RC. Caminhando para a assistência integral. In: Encontro de Pesquisadores em Saúde Mental, 5; Encontro de Especialistas em Enfermagem Psiquiátrica, 4; 1998, abr 27-30; Ribeirão Preto: Scala; 1998. p. 407.

Lefort C. A invenção democrática. Os limites do totalitarismo. $2^{2}$. ed. São Paulo: Brasiliense; 1987.

Leite F. Em SP, saúde tem $4^{\mathrm{a}}$ mudança em 2 anos. Folha de São Paulo 2003 mai 21; Cotidiano: C6.

Leite MSP. Políticas sociais e cidadania. Physis (RJ) 1991; 1(1): 117-31.

Leite MP, Rizek, CS. Cadeias, complexos e qualificações. In: Leite MP, Neves MA, organizadores. Trabalho, qualificação e formação profissional. São Paulo; Rio de Janeiro: ALAST; 1998. p. 45-76.

Lemos CTG. Desenvolvimento da linguagem e processo de subjetivação. Interações Estud Pesq Psicol 2000; 5(10): 53-72.

Lima LAFSS. Hygiene mental e educação. Rio de Janeiro; 1927. [Tese de Doutorado - Faculdade de Medicina da UERJ]. 
Lobato A, organizador Manual de orientação para uso de psicofármacos. Brasilia (DF): Ministério da Saúde. Divisão Nacional de Saúde Mental; 1983.

Lopes RC. Programas de saúde mental: a proposta de uma concepção alternativa São Paulo; 1982. [Dissertação de Mestrado - Faculdade de Medicina da USP].

Luís MAV. Contribuição à assistência de enfermagem de saúde mental dirigida à população de gestantes em nível de prevenção primária. Ribeirão Preto; 1983. [Dissertação de Mestrado - Escola de Enfermagem de Ribeirão Preto/USP].

Luz MT. As instituições médicas no Brasil Rio de Janeiro: Graal; 1979.

Luz MT. Medicina e ordem política brasileira. Rio de Janeiro: Graal; 1982.

Luz MT. Notas sobre as políticas de saúde no Brasil de "transição democrática" anos 80. Physis (RJ) 1991; 1(1): 77-96.

Macedo MRC. Políticas de saúde mental Rio de Janeiro; 1981. [Dissertação de Mestrado - Instituto de Medicina Social da UERJ].

Machado MH, organizador. Profissões em saúde: uma abordagem sociológica. Rio de Janeiro: FIOCRUZ; 1995.

Machado R. Danação da norma: medicina social e constituição da psiquiatria no Brasil. Rio de Janeiro: Graal; 1978.

Maimone CF. Linguagem e ensino: uma proposta em questão. Interações Estud Pesq Psicol 2000; 5(10): 73-94. 
Mângia EF. Terapia ocupacional: práticas, discursos e a questão da legitimidade científica Rev Ter Ocup USP 1999; 10(2/3): 57-62.

Mângia EF. A trajetória da terapia ocupacional da psiquiatria às novas instituições e estratégias de promoção de saúde mental. Rev Ter Ocup USP 2000; 11(1): 84-93.

Marcolan JF. Opinião dos enfermeiros que atuam em enfermagem psiquiátrica e em saúde mental no município de São Paulo sobre suas ações. São Paulo; 1996. [Dissertação de Mestrado - Escola de Enfermagem da USP].

Martins L. Estado capitalista e burocracia no Brasil pós 64. Rio de Janeiro: Paz e Terra; 1985.

Marx K O capital: crítica da economia política. $12^{\mathrm{a}}$. ed. Rio de Janeiro: Bertrand Brasil; 1988. v.1.

Mattos AM. Participação popular ou cidadania regulada: movimentos populares pela saúde no Rio de Janeiro (1980-1988). Rio de Janeiro; 1990. [Dissertação de Mestrado - Instituto de Filosofia e Ciências Sociais da UFRJ].

Medeiros TA. Formação do modelo assistencial psiquiátrico no Brasil. Rio de Janeiro; 1977. [Dissertação de Mestrado - Instituto de Psiquiatria da UFRJ].

Melman J. Repensando o cuidado em relação aos familiares de pacientes com transtorno mental. São Paulo; 1998. [Dissertação de Mestrado - Faculdade de Medicina da USP].

Mendes EV. Distrito sanitário: o processo social de mudança das práticas sanitárias do Sistema Único de Saúde. São Paulo: Hucitec; 1993. 
Mendes-Gonçalves RB. Medicina e história: raizes sociais do trabalho médico. São Paulo; 1979. [Dissertação de Mestrado - Faculdade de Medicina da USP].

Mendes-Gonçalves RB. Práticas de saúde: processos de trabalho e necessidades. São Paulo: Centro de Formação dos Trabalhadores em Saúde; 1992. [Cadernos CEFOR, 1].

Mendes-Gonçalves RB. Tecnologia e organização social das práticas de saúde: características tecnológicas de trabalho na rede estadual de centros de saúde de São Paulo. São Paulo: Hucitec/ABRASCO; 1994.

Meola ME. Identidade e complexidade: composições no campo da terapia ocupacional. Rev Ter Ocup USP 2000; 11(1): 44-55.

Merhy EE. $\mathbf{O}$ capitalismo e a saúde pública: a emergência das práticas sanitárias no Estado de São Paulo. $2^{\circledR}$. ed. Campinas: Papirus; 1987.

Merhy EE, Onocko R, organizadores. Agir em saúde: um desafio para o público. São Paulo: Hucitec; 1997.

Mielnik I. Higiene mental do trabalho. São Paulo: Artes Médicas; 1976.

Minayo MCS. O desafio do conhecimento científico: pesquisa qualitativa em saúde. $2^{a}$ ed. São Paulo/Rio de Janeiro: Hucitec/ABRASCO; 1993.

Minayo MCS, organizador. Pesquisa social: teoria, método e criatividade. Petrópolis: Vozes; 1995.

Ministério da Saúde. $1^{\mathrm{a}}$. Conferência Nacional de Saúde Mental. Brasília (DF); 1987. 
Ministério da Saúde. Departamento de Informática. Sobre o Sistema Único de Saúde. Secretaria de Assistência à Saúde - SAS, 2001.

Ministério da Saúde. $3^{\mathrm{a}}$. Conferência Nacional de Saúde Mental: Cuidar sim, excluir não. Consolidação dos Relatórios Estaduais. Brasilia; 2001.

Montanari PM. Da limitação da deficiência à superação na vida: jovens, portadoras de deficiências físicas. São Paulo; 1998. [Dissertação de Mestrado Faculdade de Saúde Pública da USP].

Montanari PM. Jovem e deficiência: comportamento e corpos desviantes. In: Ministério da Saúde. Secretaria de Políticas de Saúde. Área de saúde do adolescente e do jovem Cademos Juventude, saúde e desenvolvimento. Brasilia (DF); 1999. v.1, p. $97-108$

Nemes MIB. Ação programática em saúde: referenciais para análise da organização em serviços de atenção primária. Espaço Saúde 1990; 2(2): 40-5.

Nemes MIB. Prática programática em saúde. In: Schraiber LB, organizador. Saúde do adulto: programas e ações na unidade básica. São Paulo: Hucitec; 1996.

Nogueira $O$. Contribuição ao estudo das profissões de nível universitário no Estado de São Paulo. Osasco; 1967. [Tese de Livre Docência - Faculdade Municipal de Ciências Econômicas e Administrativas de Osasco-SP].

Nogueira RP A força de trabalho em saúde. In: Médici AC, organizador. Textos de apoio: planej. 1 - recursos humanos em saúde. Rio de Janeiro: PEC/ABRASCO; 1988. p. $13-8$. 
Nunes Filho EP, Bueno JR, Nardo AE. Psiquiatria e saúde mental: conceitos clínicos e terapêuticos fundamentais. São Paulo: Atheneu; 1996.

Oliveira J.A, Teixeira SMF. (Im)Previdência Social: 60 anos de histónia da Previdência no Brasil. Petrópolis: Vozes/Rio de Janeiro: ABRASCO; 1986.

Oliveira RA, Marroni CA. Residência médica: 25 anos no Brasil. Rev Diag Trat 2002; 8: $31-4$.

Organização Mundial da Saúde. Relatório sobre a saúde no mundo 2001 - Saúde Mental: nova concepção, nova esperança. Genebra; 1991.

Paim JS. Recursos humanos em saúde no Brasil: problemas crônicos e desafios agudos. São Paulo: FSP/USP; 1994. (Sèrie AdSaúde, 1).

Palma JJL. Os trabalhadores em saúde: agentes, práticas e instituições em São Paulo, 1917 -1945. São Paulo; 1996. [Dissertação de Mestrado da Faculdade de Medicina da USP].

Peduzzi M, Palma JJL. A equipe de saúde. In: Schraiber LB, organizador. Saúde do adulto: programas e ações na unidade bảsica. São Paulo: Hucitec, 1996.

Peduzzi M. Equipe multiprofissional: a interface entre processo de trabalho e interação. Campinas; 1998. [Tese de Doutorado - Faculdade de Ciências Médicas da UNICAMP].

Pereira Urquiza LMF. Um tratamento para a loucura: contribuição à história da emergência da prática psiquiátrica no estado de São Paulo. Campinas; 1991. [Dissertação de Mestrado - Faculdade de Ciências Médicas da UNICAMP]. 
Pereira A. Reformas da ilusão: a terapêutica psiquiátrica em São Paulo na primeira metade do século XX. Campinas; 1996 [Tese de Doutorado - Faculdade de Ciências Médicas da UNICAMP].

Pirotta KCM. Não há guarda chuva contra o amor: estudo do comportamento reprodutivo dos estudantes da USP. São Paulo; 2002. [Tese de Doutorado Faculdade de Saúde Pública da USP].

Pitta Hoisel AM. Sobre uma política de saúde mental. São Paulo; 1984. [Dissertação de Mestrado - Faculdade de Medicina da USP].

Pitta AM F. Avaliação como processo de melhora da qualidade de serviços públicos de saúde. Rev Adm Pública 1992; 26(2): 44-61.

Pompei MS. Avaliação da qualidade da assistência ambulatorial em saúde mental: um estudo das relações entre processo e resultado final São Paulo; 1996. [Tese de Doutorado - Faculdade de Saúde Pública da USP].

Prefeitura do Município de São Paulo. Plano de atendimento à saúde: projeto básico - versão 2. São Paulo; 1996.

Preti D, organizador. Análise de textos orais. São Paulo: EPU/FFLCH/USP; 1993.

[PUC] - Programa de Estudos Pós-Graduandos em Serviço Social. Uma trajetória da docência em Serviço Social - período 1936/1976. São Paulo; 1994.

Quiroga C. Uma invasão às ocultas: reduções positivistas no marxismo e suas manifestações no ensino da metodologia no Serviço Social. Belo Horizonte; 1989. [Dissertação de Mestrado - Faculdade de Serviço Social da UFMG]. 
Ribeiro JM, Schraiber LB. A autonomia e o trabalho em medicina. Cadernos de Saúde Pública 1994; 10(2):90-99.

Ribeiro MAR. História sem fim... Inventário da saúde pública. São Paulo - 18801930. São Paulo: Editora da Universidade Estadual Paulista; 1993.

Rosário NA. Lutas urbanas e controle social. $2^{\text {a }}$. ed. Petrópolis: Vozes/Rio de Janeiro: ABRASCO; 1986.

Sá ENC. Análise de uma organização pública complexa no setor saúde: o conjunto Juqueri, no Estado de São Paulo. São Paulo; 1983. [Tese de Doutorado Faculdade de Saúde Pública da USP].

Sá ENC. O manicômio judiciário: saúde ou justiça? Rev Saúde Pública 1985; 19 : $389-400$.

Sá ENC, organizador. Modernização administrativa de uma instituição pública complexa do setor saúde: o conjunto Juqueri, no Estado de São Paulo - Brasil: relato da continuação do processo/julho 1991. In: Jornadas sobre modernização administrativa de instituições complexas de assistência psiquiátrica. São Paulo; 1991.

Sá ENC, organizador. Modernização administrativa de uma instituição pública complexa do setor saúde: o conjunto Juqueri, no Estado de São Paulo - Brasil: relato da continuação do processo/julho 1991. Rev Paul Hosp 1994: 41:10-5.

Sá ENC. Juqueri: o espinho adormecido. Parte 1. São Paulo: Hucitec; 1991. (Saúde em Debate, 39). 
Sá ENC, organizador. Éxodo forçado de servidores da Secretaria Municipal de Saúde de São Paulo em decorrência da implantação do PAS - Plano de Atendimento à Saúde. São Paulo: Faculdade de Saúde Pública; 1997.

Sader ES. A transição no Brasil: da ditadura à democracia? $7^{\mathbf{a}}$. ed. São Paulo: Atual; 1990. (Série História Viva).

Santos ACS. Da clinica psychiatrica e do ambulatório de hygiene mental. São Paulo; 1931. [Tese de Doutorado - Faculdade de Medicina da USP].

Santos MA, organizador. Serviço de emergência psiquiátrica em hospital universitário: estudo prospectivo. Rev Saúde Pública 2000; 34: 468-74.

Santos WG. 1964: anatomia da crise. São Paulo: Vértice; 1986.

Scarcelli IR, organizador. O movimento antimanicomial e a rede paulista de saúde mental. In: Resumos do $4^{\circ}$. Congresso Interno do Instituto de Psicologia da USP. São Paulo: Instituto de Psicologia da USP; 1998. p. 128.

Schraiber LB. Educação médica e capitalismo: um estudo das relações educação e prática médica na ordem social capitalista. São Paulo: Hucitec/Rio de Janeiro: ABRASCO; 1989.

Schraiber LB. O médico e seu trabalho: limites da liberdade. São Paulo: Hucitec; 1993.

Schraiber LB. A pesquisa qualitativa em saúde: reflexões metodológicas do relato oral e produção de narrativas em estudo sobre a profissão médica Rev Saúde Pública 1995; 29: 63-74. 
Schraiber LB, Paim JS, Ayres JRCM. Trabalho em saúde: contribuições dos estudos sobre processo de trabalho e organização social das práticas de saúde. Saúde em debate 1997; (n. especial): 22p.

Schraiber LB, Peduzzi M. Recursos humanos e trabalho coletivo em saúde: a equipe multiprofissional. Coordenação de Pesquisas - Divisão de Saúde e Desenvolvimento Humano. Washington, (D.C.): OPS; 1999. [Documentos Técnicos 11].

Secretaria de Estado da Saúde. Assessoria de Saúde Mental. Departamento Psiquiátrico III. A organização básica da Secretaria de Estado da Saúde de São Paulo. São Paulo; 1987.

Secretaria de Estado da Saúde - Assessoria de Saúde Mental. Departamento Psiquiátrico II. Arq Saúde Mental. Vols. XLVII a LII, 1988/1993, 170 p.

Secretaria de Estado da Saúde. Coordenadoria de Saúde da Comunidade. Protocolo que estabelece a forma de integração de serviços da Coordenadoria de Saúde da Comunidade e da Coordenadoria de Saúde Mental. São Paulo; 1976. (mimeo)

Secretaria de Estado da Saúde. Coordenadoria de Saúde Mental. Divisão de Ambulatórios de Saúde Mental. Proposta de Trabalho para Equipes multiprofissionais em Unidades Básicas e em Ambulatórios de Saúde Mental São Paulo; 1983.

Secretaria de Estado da Saúde. Coordenadoria de Saúde Mental. Divisão de Ambulatórios de Saúde Mental. Manual de orientação à deficientes mentais (oligofrênicos) em unidades básicas e ambulatórios de saúde mental. São Paulo: 1985. 
Secretaria de Estado da Saúde. Grupo de Atenção à Saúde Mental. A reestruturação da Atenção em Saúde Mental: modelo assistencial e direito à cidadania. In: $1^{\text {a }}$ Conferência Estadual de Saúde Mental de São Paulo. São Paulo; out., 1992.

Secretaria Municipal de Saúde. Programa de Saúde Mental. São Paulo: PRODAM; 2001.

Seibel SD. Urgências psiquiátricas: o que fazer e como fazer? Rev Diag Trat 2002; 8: $50-1$

Sennett R. A corrosão do caráter: conseqüências pessoais do trabalho no novo capitalismo. Rio de Janeiro: Record; 1999.

Siqueira AAF, organizador. Morbidade e mortalidade materna, qualidade da assistência e estrutura social: estudo da região sul do município de São Paulo - Brasil. Parte II - Morbidade materna: relatório final. São Paulo: FAPESP; 1993.

Sorrentino SR. A saúde pede socorro. In: Kupstas M, organizador. Saúde em debate. São Paulo: Moderna; 1997. p. 20-33.

Souza SM. O processo brasileiro de reestruturação produtiva: uma revisão bibliográfica. Campinas; 2002. [Projeto de Mestrado em Educação - Faculdade de Educação/UNICAMP ].

Spink MJ. O sentido da doença: a contribuição dos métodos qualitativos na pesquisa sobre o câncer. In: Gimenez MG, organizadora. A mulher e o câncer. Campinas: Editorial Psy; 1997. 
Teixeira SMF. Cidadania, direitos sociais e Estado. In: Anais da $\mathbf{8}^{\mathrm{a}}$. Conferência Nacional de Saúde; 1986 mar 17-21; Brasília (DF): Centro de Documentação do Ministério da Saúde; 1987. p. 91-112.

Triviños ANS. Introdução à pesquisa em ciências sociais: a pesquisa qualitativa em educaçãa. São Paulo: Atlas; 1992.

Vasconcellos MPC. A doença mental acima de qualquer suspeita: Franco da Rocha e a prática psiquiátrica na cidade de São Paulo - 1885 a 1923. São Paulo; 1992. [Dissertação de Mestrado - Faculdade de Saúde Pública da USP].

Vasconcelos AM. A prática do Serviço Social: cotidiano, formação e alternativas na área da saúde. São Paulo: Cortez; 2002.

Velho G. Individualismo e cultura. Rio de Janeiro: Zahar; 1981.

Venancio ATA. "Nova psiquiatria" no Brasil: um estudo de caso do Hospital-Dia do Instituto de Psiquiatria. Rio de Janeiro; 1990. [Dissertação de Mestrado Programa de Pós-Graduação em Antropologia Social/Museu Nacional/UFRJ].

Venancio ATA. A construção social da pessoa e a psiquiatria: do alienismo à nova psiquiatria. Physis (RJ) 1993; 3(2): 117-135.

Wefforte F. O populismo na política brasileira. São Paulo: Brasiliense; 1975.

Yahn M. Higiene mental. São Paulo: Edigraf; 1957.

Zioni F. A questão da ética em tempos de fim de século. Mundo da saúde 2000: 24(1): 5-9. 
Anexos 


\section{Universidade de São Paulo}

Faculdade de Saúde Pública

Departamento de Saúde Materno Infantil

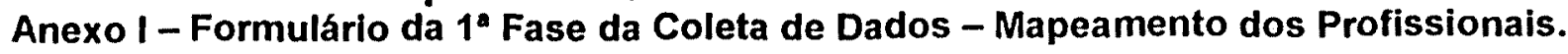

Nome do Estabelecimento:

Diretor Técnico
Tipo Institucional

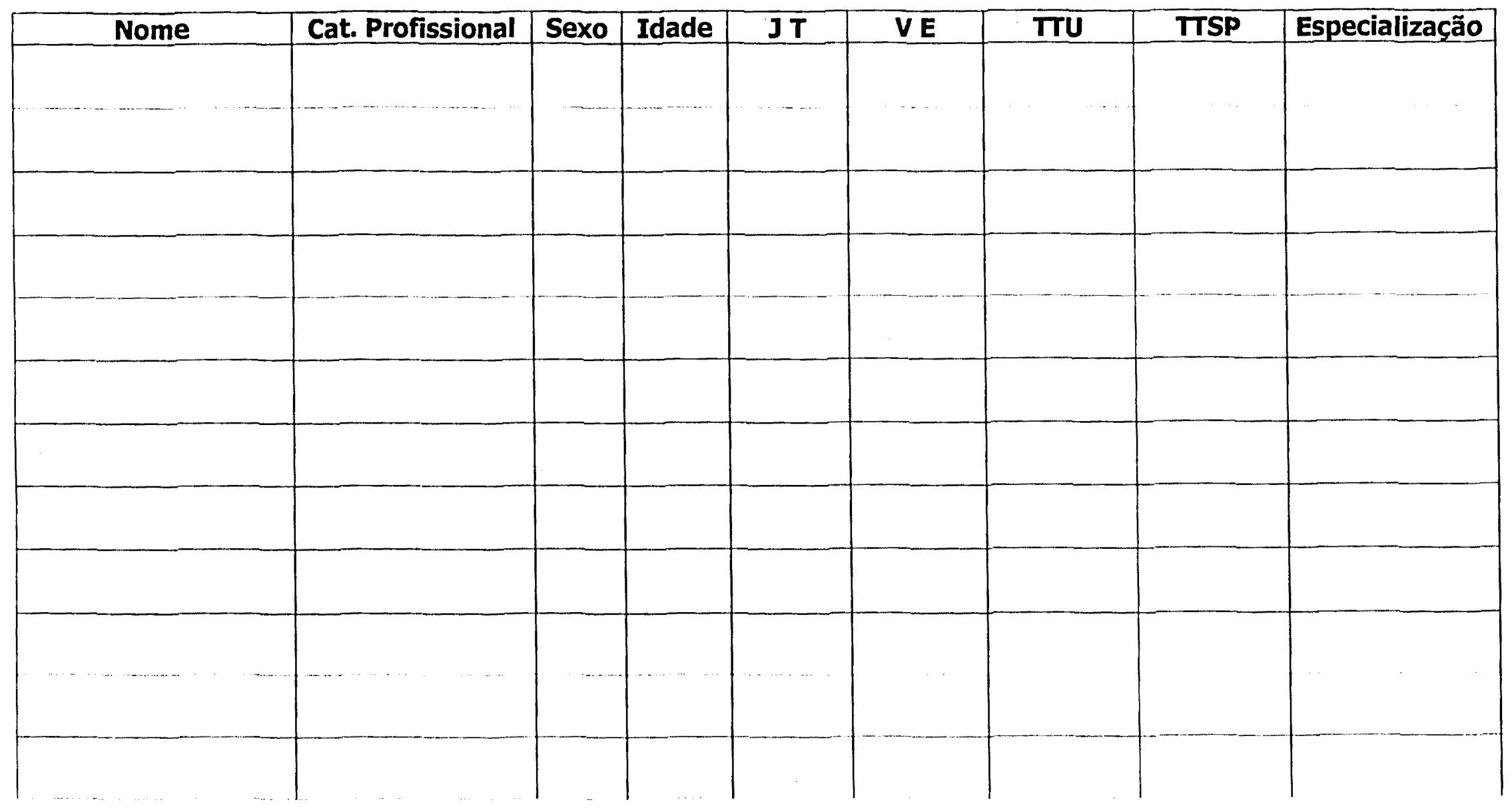




\section{Anexo 2-Roteiro de Questões para a $2^{a}$ Fase da Pesquisa}

1 - Identificação profissional e tipo de qualificação técnica especializada exigida para o exercício da profissão.

2 - Descrição das funções ocupadas atè a atual (exclusive) e interpretação pessoal do percurso, em termos de razões de ocorrência

3 - Avaliação da qualificação do exercício profissional quanto a especificidades objetivas das ações e valor dado ao desempenhado.

4 - Inserção no serviço atual: mecanismos formais de entrada, data, expectativas de função a ser desenvolvida.

5 - Enumeração de todas as atividades assistenciais do estabelecimento de saúde.

6 - Comentário sobre os profissionais que exercem tais atividades.

7 - Percepção e avaliação acerca da organização do serviço e da prestação da assistência do serviço onde trabalha.

8 - Descrição das funções atuais que realiza: regulares ou eventuais, e a relação de cada uma mencionada com outras funções da unidade (serviço).

9 - Avaliação da utilização dos produtos de trabalhos anteriores e percepção da utilização dos produtos do trabalho parcelar em si e no conjunto dos trabalhos.

10 - Percepção acerca de cada trabalho especifico e destes no conjunto dos trabalhos.

11 - Percepção sobre a colaboração na realização do trabalho

12 - Apontar os problemas mais freqüentes no cotidiano do trabalho, do serviço como um todo.

13 - Apontar os problemas mais freqüentes no cotidiano do próprio trabalho. 


\section{MUNISTÉRIO DA SAÚDE}

Conselto Nucional de Saúde

Comicusio Nacional de Etica em Pesquisa - CONEP

FOLHA DE ROSTO PARA PESQUISA ENVOLVENDO SERES HUMANOS (versåo oatubro/99)

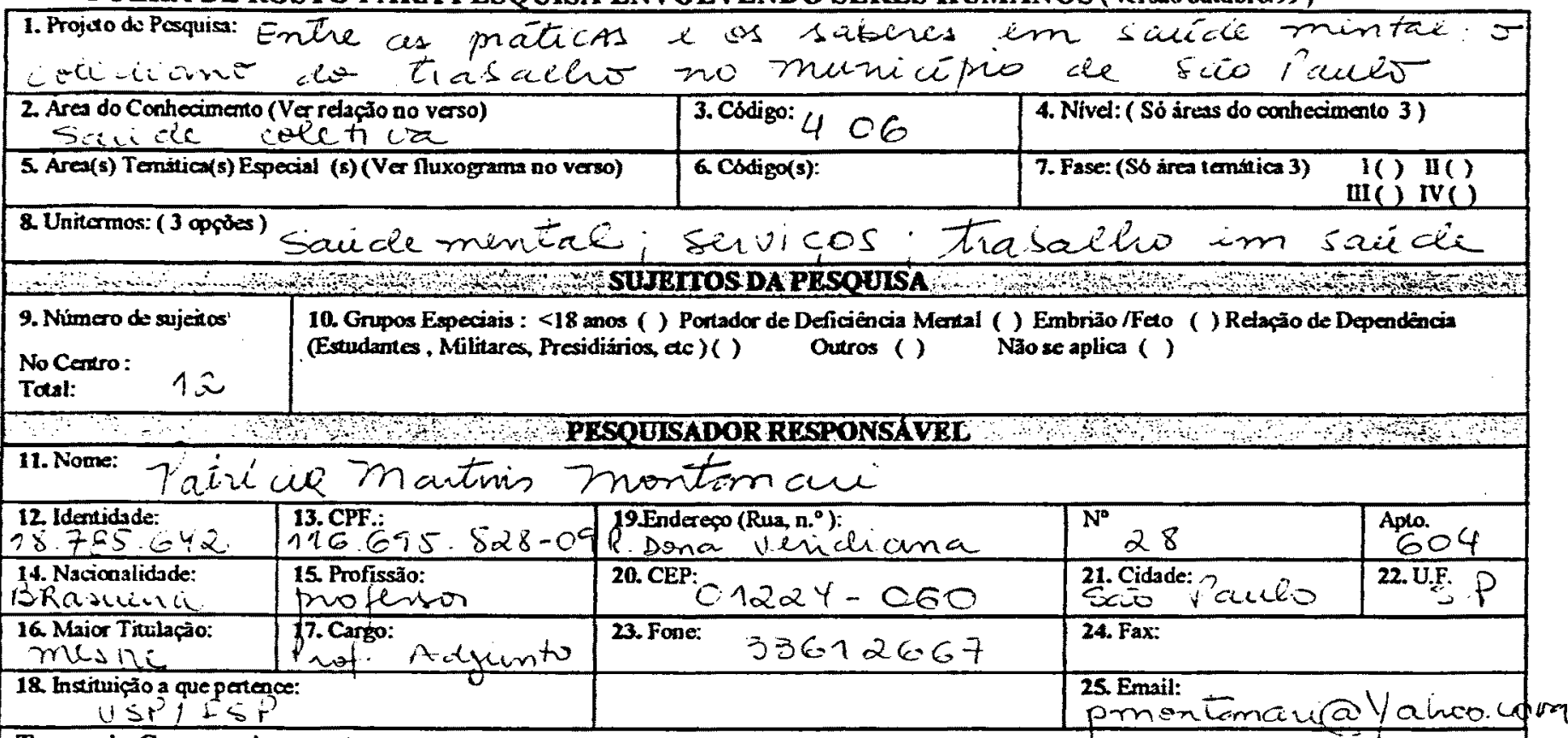

Termo de Compromisso: Declaro que conheco e cumprirei os requisitos da Res. CNS $196 / 96$ e suas complemantares. Comprometo-mé a utilizar os materiais e dados coletados exclusivamente para os fins previstos no protocolo e a pubfear os resaltados sejam eles favoriveis ou não. Aceito as responsabilidades pela conduça cientifica do projeto acima. Data: 121.10102

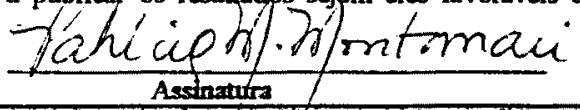

As

26. Nome:

Insciruto de Infectologia Enílio Rubas

27. Unidade Órgào:

28. Participaçio Estrangeira: Sim ( ) Nāo ()

29. Enderego (Rua, n')

Av. Dr. Amaldo, 165

30. CEP:

$01246-900$

33. Fone: (0x11) 3062-8966

31. Cidade: 32 U.

Sảo Paulo SP

34. Fax: (0x11) 3088-3954

35. Projato Mukicéntrico: Sim ( ) Não ( ) Nacional ( ) Intemacional ( ) (Anexar a lista de todos os Centros Participantes no Brasil)

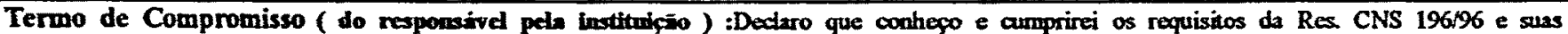
Complementares e como esta instiviçio tem condiçoses para o desenvolvimento deste projeto, autorizo sua execuçäo

Nome: Vasco Carvatho Pedroso de Lima Cargo: Diretor Técnico de Departamento

Data:

Assinatura do Direto

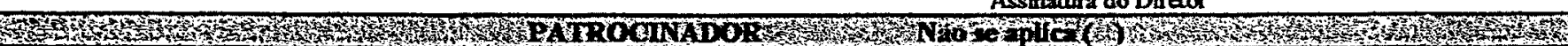

36. Norme:

37. Responsived:

38. Carzo/Funciä: 39. Endereco: 40. CEP.

43. Fone:

41. Cidade:

42. UF:

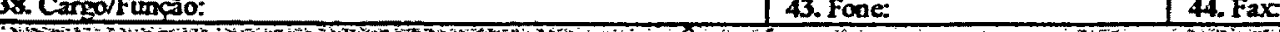

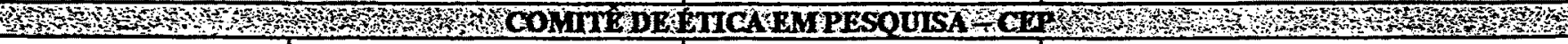

\begin{tabular}{l|l} 
45. Data de Entrada: & 46. Registro no CEP
\end{tabular}

1

46. Registro no CEP

49. Relatório(s) do Pesquisador responsivel previsto(s) para:

Encaminho a CONEP:

50. Os dados acima para registro( ) 51.0 projelo para

apreciagio( )

52. Data:

47. Conclusão: Aprovado ( )

Data:

Data:

48. N5̃o Aprovado ( )

Data:

Data:

53. Coordenador/Nome

Assinatura

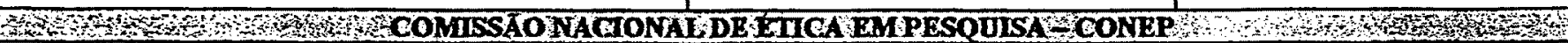

\begin{tabular}{l|l|l}
\hline 54. N Expediente: & 56.Data Recebimento: & 57. Rejistro na CONEP:
\end{tabular}

5S. Processo :

58. Observaçöes: 


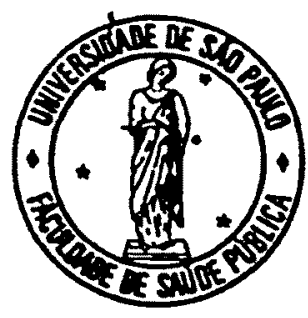

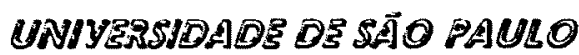

BACULDADE OS BAUOS PUIDLEA

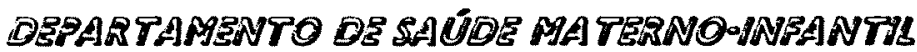

Av. Dr. Amaldo, 715 sala 218 - Cerqueira Cesar

CEP: 01246-904 São Paulo/SP

Tel.: (011) 881-2451/883-4117/3066-7702/3066-7703/3066-7773

Fax.: (011) 853-0240

E-mail: neschor@usp.br

São Paulo, maio de 2001.

$\mathrm{A} / \mathrm{C}$

Dra. Luizemir

Coordenadora da Área de Saúde Mental

SES-SP

Prezada Senhora,

Eu, Patricia Martins Montanari, aluna regularmente matriculada no programa de pós-graduação da Faculdade de Saúde Pública da USP, venho mui respeitosamente solicitar sua permissão para desenvolver minha pesquisa de doutorado nas unidades de saúde sob sua coordenação. Para tanto, necessito de sua assinatura no formulário da Comissão Nacional de Ética em Pesquisa - CONEP.

O projeto de pesquisa intitula-se Entre as práticas e os saberes em saide mental: o cotidiano do trabalho nos serviços no Municipio de São Paulo e objetiva um mapeamento, de caráter quantitativo, dos recursos humanos incorporados às equipes de saúde mental, segundo algumas variáveis, tais como: sexo, idade, jornada de trabalho, categoria profissional, especialização, tempo de trabalho na unidade, tempo de trabalho no serviço público. Num segundo momento, procederemos a uma análise de caráter qualitativo, onde serão realizadas entrevistas com os profissionais envolvidos na assistência direta, para que estes discorram e avaliem suas práticas profissionais e reflitam sobre suas percepções e representações.

Cabe informar que o presente projeto de pesquisa está sob orientação da Professora Associada Néia Schor, docente do Departamento de Saúde Materno-Infnatil FSP/USP e conta com o financiamento do CNPq.
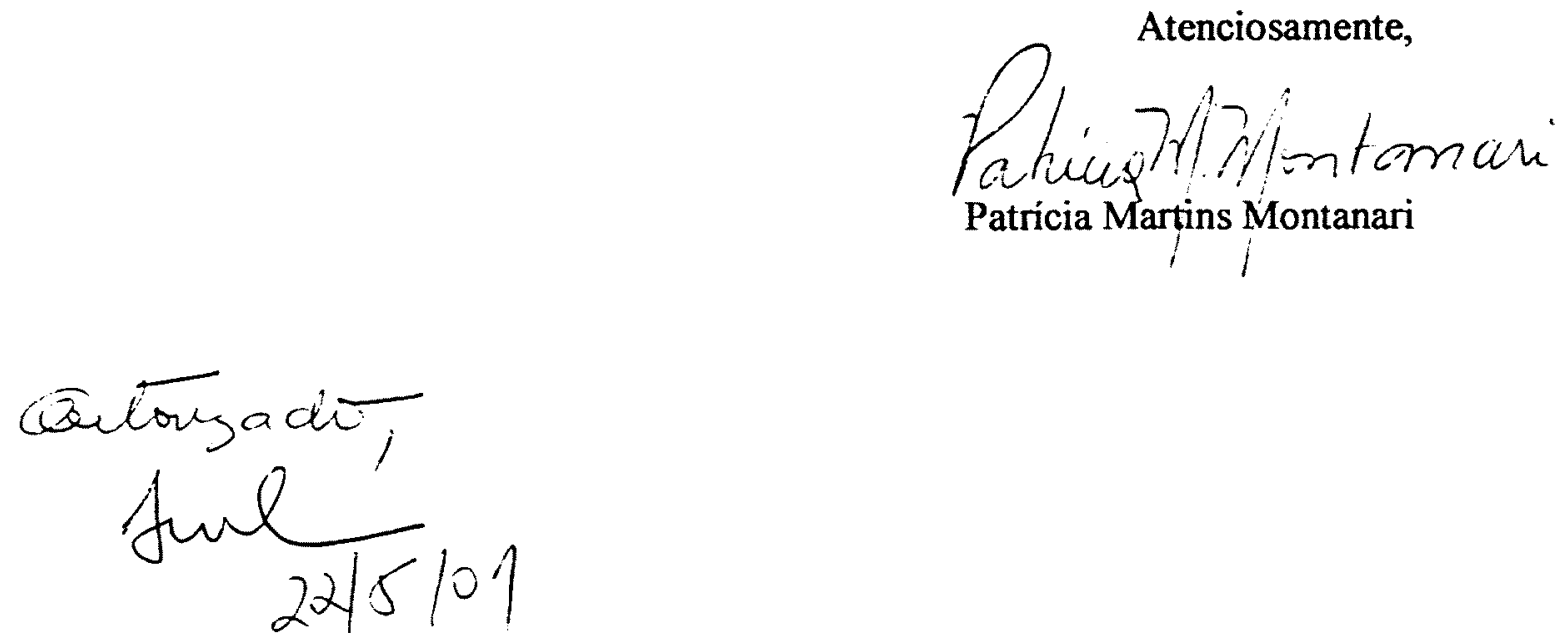


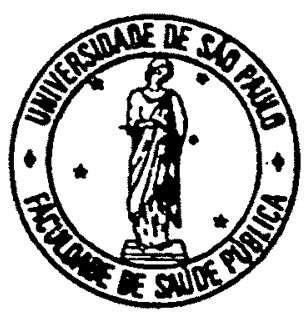

UNIYERSIDADE DESTO PAULO

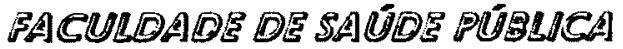

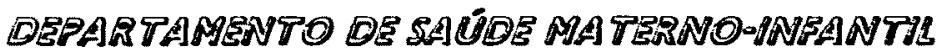

Av. Dr. Arnaldo, 715 sala 218 - Cerqueira Cesar

CEP: 01246-904 São Paulo/SP

Tel.: (011) 881-2451/883-4117/3066-7702/3066-7703/3066-7773

Fax:: (011) 853-0240

E-mail: neschor@usp.br

São Paulo, maio de 2001 .

$\mathrm{A} / \mathrm{C}$

Dr. Messias Liguori Padrão

Assistente Técnico do Programa de Saúde Mental

SMS-SP

Prezado Senhor,

Eu, Patrícia Martins Montanari, aluna regularmente matriculada no programa de pósgraduação da Faculdade de Saúde Pública da USP, venho mui respeitosamente solicitar sua permissão para desenvolver minha pesquisa de doutorado nas unidades de saúde sob sua coordenação. Para tanto, necessito de sua assinatura no formulário da Comissão Nacional de Ética em Pesquisas - CONEP.

O projeto de pesquisa intitula-se Entre as práticas $e$ os saberes em satide mental: o cotidiano do trabalho nos serviços no Municipio de São Paulo e objetiva um mapeamento, de caráter quantitativo, dos recursos humanos incorporados às equipes de saúde mental, segundo algumas variáveis, tais como: sexo, idade, jornada de trabalho, categoria profissional, especialização, tempo de trabalho na unidade, tempo de trabalho no serviço público. Num segundo momento, procederemos a uma análise de caráter qualitativo, onde serão realizadas entrevistas com os profissionais envolvidos na assistência direta, para que estes discorram e avaliem suas práticas profissionais e reflitam sobre suas percepções e representações.

Cabe informar que o presente projeto de pesquisa está sob orientação da Professora Associada Néia Schor, docente do Departamento de Saúde Materno-Infnatil - FSP/USP e conta com o financiamento do CNPq.
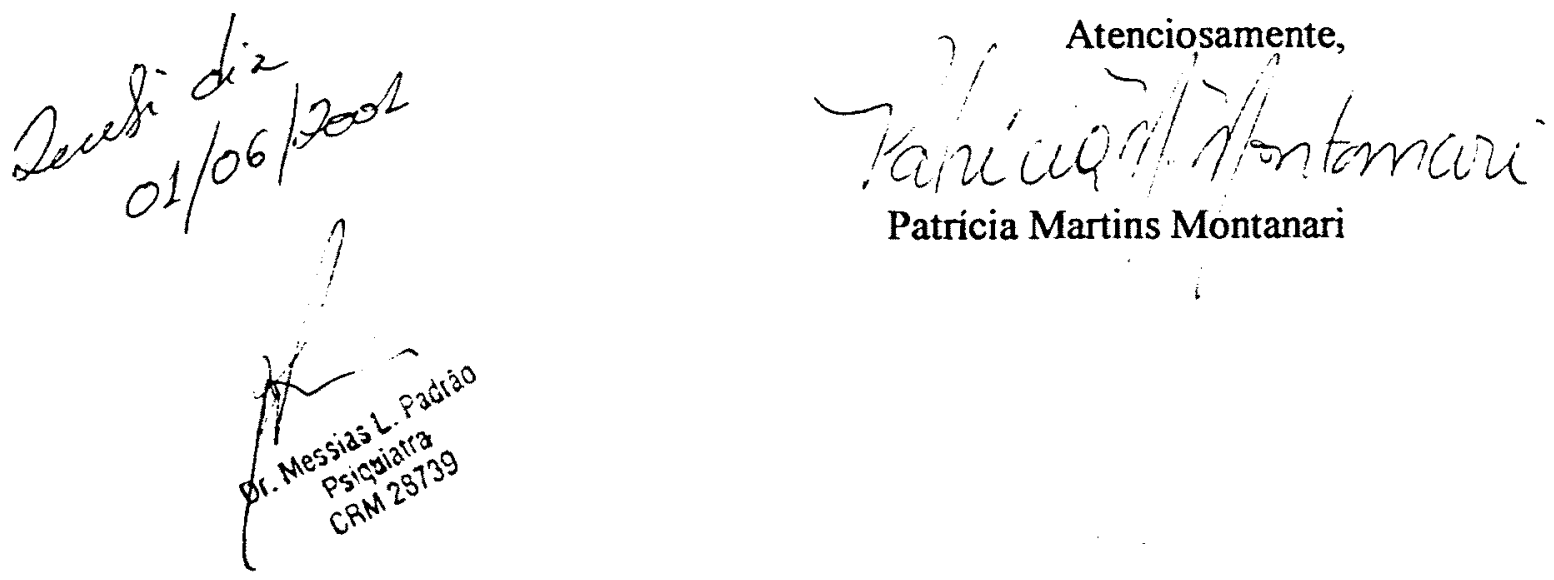

Patricia Martins Montanari 


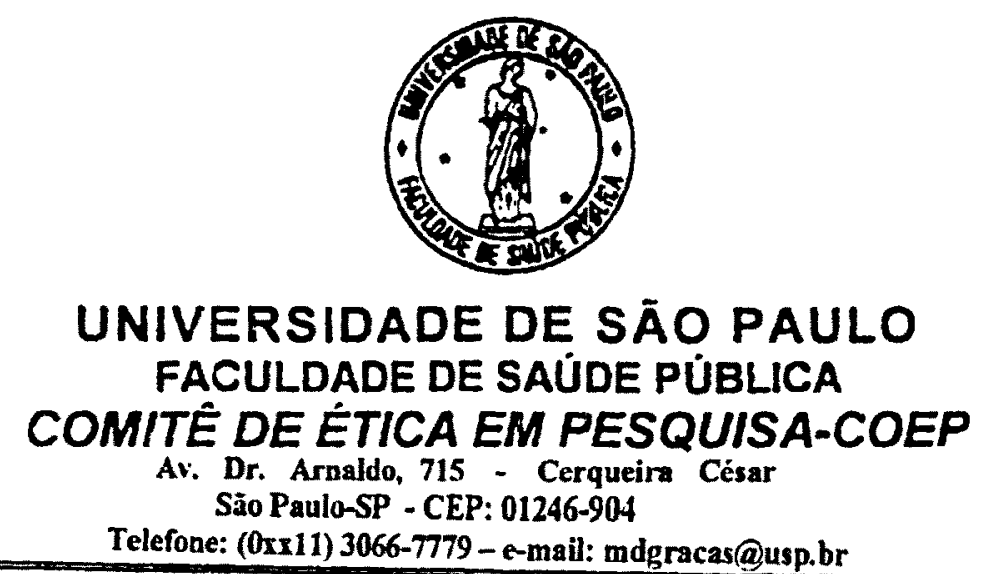

\section{Of. COEP/90/01}

19 de junho de 2001

Pelo presente, informo que o Comitê de Ética, em Pesquisa da Faculdade de Saúde Pública da Universidade de São Paulo-COEP, analisou e aprovou "adreferendum", de acordo com os requisitos da Resolução CNS/196/96, o protocolo de Pesquisa n..$^{\circ} 479$, intitulado: "ENTRE AS PRÁTICAS E OS SABERES EM SAÚDE MENTAL: O COTIDIANO DO TRABALHO NO MUNICÍPIO DE SÃO PAULO", apresentado pela pesquisadora Patrícia Martins Montanari.

Atenciosamente,

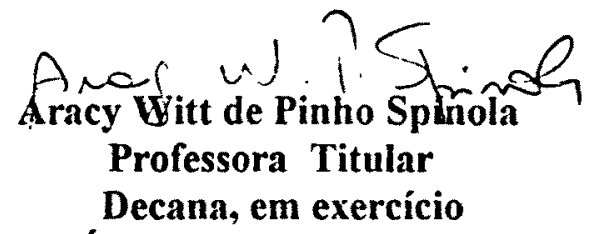

Comitê de Ética em Pesquisa da FSP-COEP 


\section{Prefeitura do Municipio de São Paulo \\ Secretaria Municipal da Saúde \\ Coordenação de Desenvolvimento da Gestão Descentralizada - COGest \\ Comitê de Ética em Pesquisa}

São Paulo, 18 de novembro de 2002

Ofício No 058/2002 - CEPSMS

Prezada Senhora,

Pelo presente, informo que o Comitê de Ética em Pesquisa da Secretaria Municipal de Saúde de São Paulo analisou, de acordo com a Resolução 196/96, o protocolo de pesquisa "Entre as práticas e os saberes em saúde mental: o cotidiano do trabalho no Município de São Paulo", de autoria da pesquisadora Patricia Martins Montanari.

Frente ao momento em que esta pesquisa se encontra, tendo concluído a coleta de dados, não cabe a este comitê emitir parecer sobre a mesma. Estamos cientes de sua realização no âmbito de SMS e solicitamos o envio do relatório final deste estudo a este CEP.

Segue, em anexo, parecer do relator.

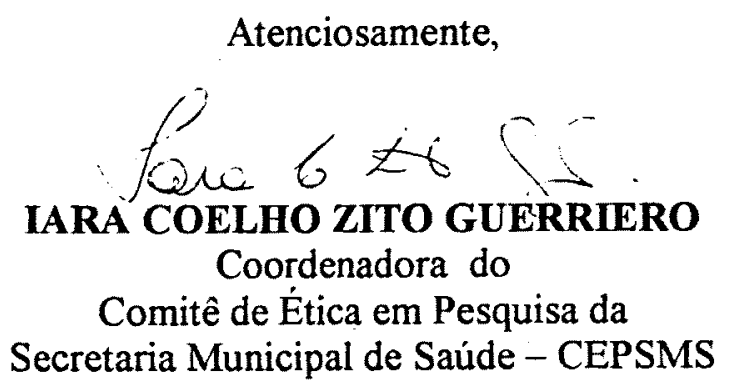

Ilma Sra.

Patrícia Martins Montamari

Faculdade de Saúde Pública/USP

Nesta 


\section{Projeto n 030 - "Entre as práticas e os saberes em saúde mental: o cotidiano do trabalho no Município de São Paulo"}

Trata-se de um projeto de doutorado, que visa “...identificar e compreender, para o Municipio de São Paulo, como os serviços de saúde do setor público prestam atendimento em saúde mental, como estão os recursos humanos efetivamente incorporados e como estes se articulam e configuram a prestação de assistência."

A pesquisadora utilizará método quantitativo para caracterizar os serviços e os profissionais que atuam nas equipes de saúde mental, e qualitativo para apreender os sentidos que os agentes atribuem a sua prática e se aproximar dos significados sociais que essas práticas vem adquirindo para os usuários e seus familiares.

Trata-se, sem dúvida, de um estudo relevante, que pode contribuir para o planejamento e a implementação de políticas públicas na área de saúde mental, na cidade de São Paulo.

Entretanto, ao ler a documentação apresentada, observei que a pesquisadora tinha parecer favorável do Comitê de Ética em Pesquisa da Faculdade de Saúde Pública desde junho de 2001, período que este comitê não estava instalado, e autorização da Secretaria Municipal de Saúde/SMS, através do então Assistente Técnico da Área de Saúde Mental, Dr Messias, desde maio de 2001. Solicitei à senhora Alice, secretária do CEPSMS, que verificasse junto à pesquisadora, em que fase o trabalho estava, em especial no que se refere à coleta de dados. Através de contato telefônico, a pesquisadora informou que a coleta de dados estava praticamente concluida. Frente a esta informação, parece-me que não cabe a este CEP emitir parecer para um estudo que já está com os dados levantados.

Considero importante que o relatório final desta pesquisa seja enviado a este CEP, para posterior divulgação, uma vez que os mesmos podem ser de grande utilidade para os gestores de saúde desta cidade.

Data: $18 / 11 / 2002$ 


\section{Anexo 7-Modelo}

\section{TERMO DE COMPROMISSO ÉTICO}

Alicerçada nas normas Éticas Internacionais para Investigações Biomédicas com Seres Humanos - Cioms 1982/1896, na Resolução 196/96 do Conselho Nacional de saúde e em FORTES (1998), o presente estudo, que insere-se no âmbito da pesquisa qualitativa, com intersecção no campo das Ciências Humanas, e que utilizará entrevistas abertas, semi-estruturadas, objeto de posterior análise de discurso respeitará os seguintes critérios:

1. Entre a população definida para a entrevista, a participação será voluntária, os sujeitos serão autônomos, capazes legalmente e não vulneráveis.

2. O sujeitos serão convidados a participar da presente pesquisa respondendo a roteiro temático de entrevista, que intenciona estimular resposta pessoal e opinativa a respeito de sua trajetória profissional, significados de suas práticas e das relações de trabalho estabelecidas ao longo do trabalho.

3. As entrevistas serão realizadas em ambiente propicio, serão gravadas e posteriormente transcritas. Serão feitas individuaimente, sem a presença de outras pessoas com a preservação da privacidade.

4. Será assegurada a liberdade de recusa ou desistência em qualquer momento da investigação sem que isto implique em qualquer tipo de rechaço ou retaliação ao sujeito entrevistado.

5. Haverá cuidado e respeito com as informações obtidas e serão preservados a identidade de pessoas citadas pelos entrevistados.

6. Será apresentado, pela entrevistadora, a todos os sujeitos que participarem desta pesquisa o Termo de Consentimento Livre e Esclarecido que será previamente lido, explicitado e solicitada a assinatura do entrevistado que será a condição para sua participação. 


\section{Anexo 7 - Modelo \\ CONSENTIMENTO LIVRE E ESCLARECIDO}

Fui convidada(o) a participar, na condição de entrevistada(o), da pesquisa que está sendo desenvolvida pela aluna Patrícia Martins Montanari, aluna regularmente matriculada no programa de pós graduação, nivel doutorado, da Faculdade de Saúde Pública da Universidade de São Paulo - USP, número USP 1560060, sob orientação da Professora Associada Néia Schor, do departamento de Saúde Materno infantil.

Fui informada que posso, a qualquer momento no decurso da entrevista, recusar ou desistir de respondê-la, por completo ou parcialmente, sem que isto se traduza em qualquer tipo de rechaço ou retaliação.

Foi explicado que a minha participação consistirá em responder questões acerca de minha formação acadêmica, trajetória profissional e atuação profissional atual.

Fui tambèm informada(o) que as entrevistas serão gravadas e posteriormente transcritas, que o tratamento dado ao material obtido será respeitoso e que haverá preservação de minha identidade pessoal em todos os fóruns em que os dados de pesquisa forem apresentados.

Este termo de consentimento foi lido e explicitado e decidi participar da pesquisa de forma livre e esclarecida.

Assinatura da(o) entrevistada(o)

Nome da(o) entrevistada(o)

Data

Telefones: 9983.3490 (cel.)/3361.2667 (res.)

Departamento de Saúde Materno Infantil/USP: 30667702 e 30667703 


\section{Glossário}

AIS - Ações Integradas de Saúde

CAP - Caixas de Aposentadoria e Pensões

CEAS - Centro de Estudos e Ação Social

CEFOR - Centro de Formação em Saúde

CJ - Centro de Juventude

COREN - Conselho Regional de Enfermagem

EGJ - Espaço Gente Jovem

EMEI - Escola Municipal de Educação Infantil

EPM - Escola Paulista de Medicina

FMU - Faculdades Metropolitanas Unidas

HD - Hospital Dia

IAP - Instituto de Aposentadoria e Pensões

INAMPS - Instituto Nacional de Assistência Médica e Previdência Social

INPS - Instituto Nacional de Previdência Social

NAE - Núcleo de Ação Educativa

NOA - Núcleo de Obras e Assistência

PAS - Plano de Atendimento à Saúde

PC - Paralisia Cerebral

PUC - Pontificia Universidade Católica

SAS - Secretaria de Assistência Social

SEBES - Secretaria Municipal do Bem-Estar Social

SURBES - Superintendência Regional do Bem-Estar Social

SUS - Sistema Único de Saúde

TO - Terapeuta Ocupacional

UBS - Unidade Básica de Saúde

UNIFESP - Universidade Federal de São Paulo

USP - Universidade de São Paulo 